\title{
THE IMPACT OF THREAT ENVIRONMENTS ON WESTERN PATTERNS OF CIVIL-MILITARY RELATIONS (SE]PTEMBER 11, 2001-SEPTEMBER 11, 2006)
}

by

\section{DRAGOŞ CONSTANTIN POPA, M.A.}

\author{
A thesis submitted to \\ the Faculty of Graduate Studies and Research \\ in partial fulfillment of \\ the requirements for the degree of \\ Doctor of Philosophy \\ Department of Political Science
}
Carleton University
Ottawa, Canada
2008

(C) Dragoş Constantin Popa 


$\begin{array}{ll}\begin{array}{l}\text { Library and } \\ \text { Archives Canada }\end{array} & \begin{array}{l}\text { Bibliothèque et } \\ \text { Archives Canada }\end{array} \\ \begin{array}{l}\text { Published Heritage } \\ \text { Branch }\end{array} & \begin{array}{l}\text { Direction du } \\ \text { Patrimoine de l'édition }\end{array} \\ \begin{array}{l}\text { 395 Wellington Street } \\ \text { Ottawa ON K1A 0N4 } \\ \text { Canada }\end{array} & \begin{array}{l}\text { 395, rue Wellington } \\ \text { Ottawa ON K1A 0N4 } \\ \text { Canada }\end{array}\end{array}$

Your file Votre référence ISBN: 978-0-494-43904-3 Our file Notre référence ISBN: 978-0-494-43904-3

NOTICE:

The author has granted a nonexclusive license allowing Library and Archives Canada to reproduce, publish, archive, preserve, conserve, communicate to the public by telecommunication or on the Internet, loan, distribute and sell theses worldwide, for commercial or noncommercial purposes, in microform, paper, electronic and/or any other formats.

The author retains copyright ownership and moral rights in this thesis. Neither the thesis nor substantial extracts from it may be printed or otherwise reproduced without the author's permission.
AVIS:

L'auteur a accordé une licence non exclusive permettant à la Bibliothèque et Archives Canada de reproduire, publier, archiver, sauvegarder, conserver, transmettre au public par télécommunication ou par l'Internet, prêter, distribuer et vendre des thèses partout dans le monde, à des fins commerciales ou autres, sur support microforme, papier, électronique et/ou autres formats.

L'auteur conserve la propriété du droit d'auteur et des droits moraux qui protège cette thèse. $\mathrm{Ni}$ la thèse ni des extraits substantiels de celle-ci ne doivent être imprimés ou autrement reproduits sans son autorisation.
In compliance with the Canadian Privacy Act some supporting forms may have been removed from this thesis.

While these forms may be included in the document page count, their removal does not represent any loss of content from the thesis.
Conformément à la loi canadienne sur la protection de la vie privée, quelques formulaires secondaires ont été enlevés de cette thèse.

Bien que ces formulaires aient inclus dans la pagination, il n'y aura aucun contenu manquant.

\section{Canada}




\begin{abstract}
This thesis investigates patterns of civil-military relations in Western countries over a period of five years (September 11, 2001-September 11, 2006). It argues that there is a direct correlation between specific threat environments (the independent variables) and models of civil-military interaction (the dependent variables). To link analytically the overall threat configuration during the given timeframe to civil-military relations, the thesis identifies five intermediate variables: (i) defence spending, (ii) government policies, (iii) defence transformation, (iv) relations with the United States of America and (v) military responses to the new threat environment. Employing two case studies, Canada and Romania, the thesis tests and provides evidence against the validity of one of the major theoretical constructs in the field of civil-military relations, Michael C. Desch's framework on the relationship between threat configurations and forms of civilian oversight of the armed forces. The thesis argues that in the first five years of the post9/11 era countries such as Canada and Romania faced an indeterminate threat environment that did not fit closely any of Desch's categories. During this five-year timeframe, the empirical data gathered from the two national contexts suggest that there were frequent instances of serious disagreement between civilian and military leaders. While the overall principle of civilian control over the armed forces was not openly called into question, the study revealed discordance between the two sides on many of the issue areas investigated in this thesis. The empirical findings and theoretical implications tend to falsify Desch's theory or render it irrelevant in most cases potentially applicable to contemporary Western polities. The thesis assesses the observed data and Desch's framework against the background of other theoretical constructs and offers a set of research suggestions meant to advance future work in the field of civil-military relations.
\end{abstract}




\section{Dedication and Acknowledgements}

This thesis is dedicated to my wife, Iulia. Without her amazing patience, invaluable advice, constant encouragement and unconditional love I could not have achieved this goal. It is equally dedicated to our two sons, Thomas and David - who were born during the process of writing this thesis - as a source of future inspiration and proof that hard work and perseverance pay off in the end.

I am deeply indebted to Professor Piotr Dutkiewicz (Carleton University), who kindly agreed to be my supervisor and mentor for the past seven years, during my M.A. and $\mathrm{Ph}$.D. programs at Carleton University. I would like to express my gratitude for his continuous guidance, academic support and encouragement throughout these years, and to note his vast knowledge and expertise in many academic areas and his selfless dedication to students' well-being.

I am also extremely grateful to the other members of my committee, particularly Professor Joel J. Sokolsky (Royal Military College) for taking time out from his busy schedule to serve as my external reader and for his many and very insightful comments on various drafts of this thesis. Special thanks go to Professor Harald von Riekhoff (Carleton University) who provided me with direction and technical support at many junctures while working on this dissertation. Deep thanks to Professor Norman Hillmer (Carleton University) and Professor Elinor Sloan (Carleton University) for suggesting improvements at a time when I was not aware of the extent to which the thesis needed revisions, thus making it a much better manuscript. Their vast expertise and kind willingness to share their knowledge with students are greatly appreciated.

I would like to acknowledge, for the positive impact they made on my academic life, Professor Joan DeBardeleben (Carleton University), Professor Morgan Wilhelmsson (Högskolan i Jönköping) and Professor Tudor Vlad (Universitatea Babeş-Bolyai and University of Georgia).

This thesis has partly been supported through a Social Sciences and Humanities Research Council of Canada doctoral fellowship, an Edward Bower Carty Scholarship for Outstanding Students, other scholarships provided by Carleton University and a travel research grant provided by the European Commission through the Centre for European Studies at Carleton University. Their support is gratefully acknowledged. 
Table of Contents

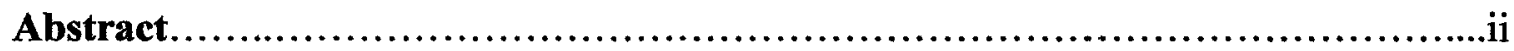

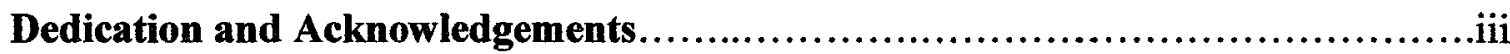

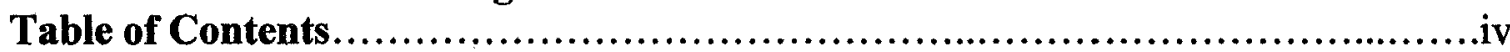

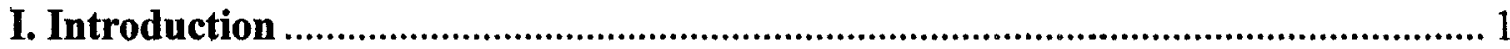

II. Theoretical Foundations and Methodological Approaches ............................... 4

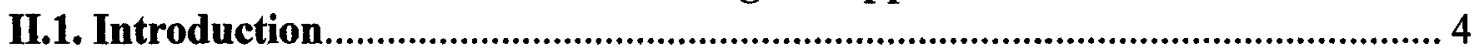

II.2. Analytical statements and methodological framework ............................... 4

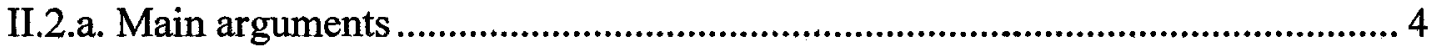

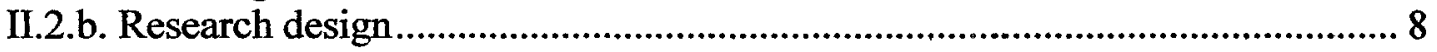

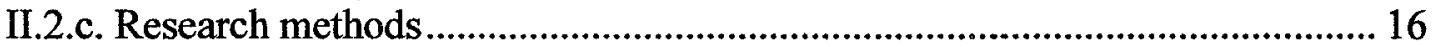

II.3. The place of the study in the civil-military relations literature ...................... 20

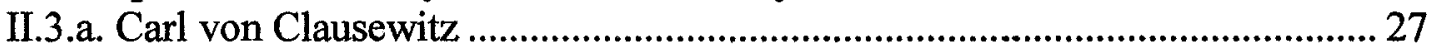

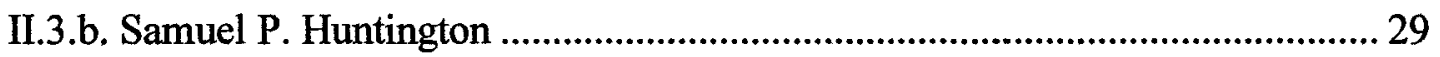

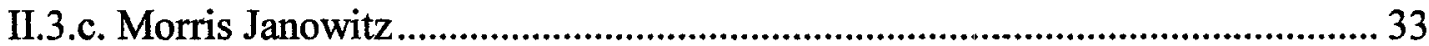

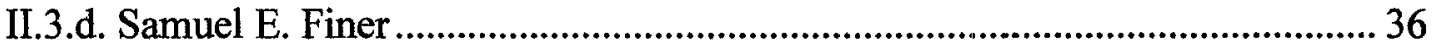

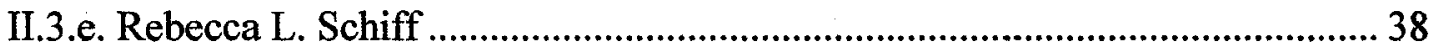

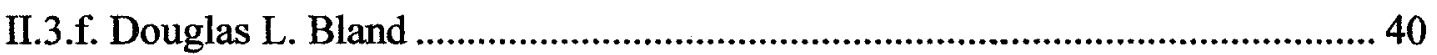

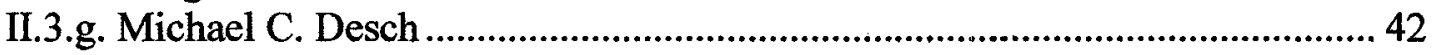

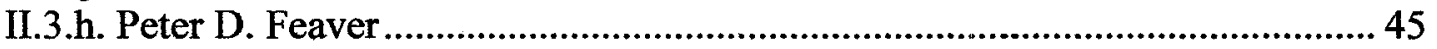

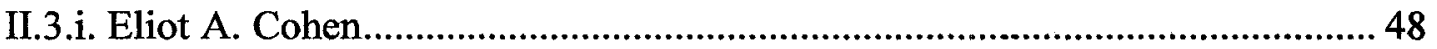

III. New Threat Environment, New Strategic Priorities ......................................... 51

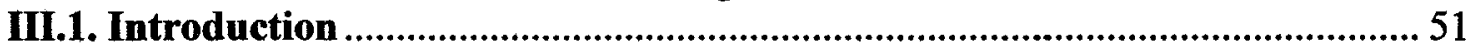

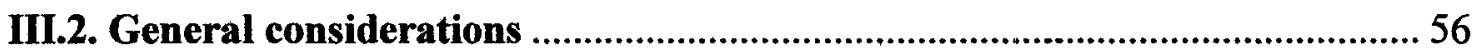

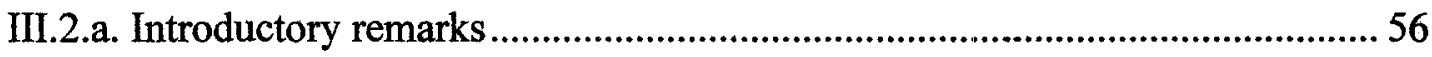

III.2.b. The impact of $9 / 11$ on the post-Cold War world order............................... 59

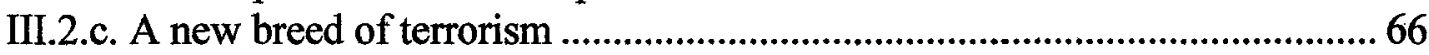

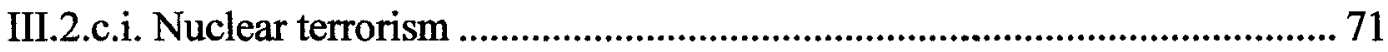

III.2.c.ii. Chemical terrorism............................................................................. 74

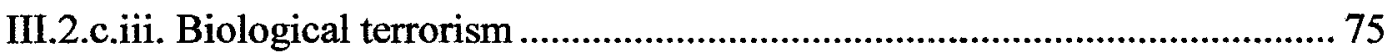

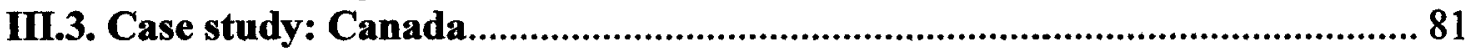

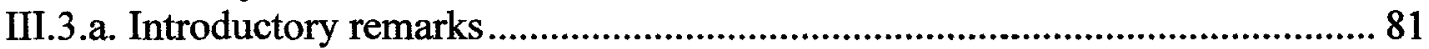

III.3.b. The Canadian perspective on the new security environment...................... 83

III.3.c. Post-9/11 security concerns in Canada .................................................... 92

III.3.d. A "fire-proof house" no more ........................................................... 100

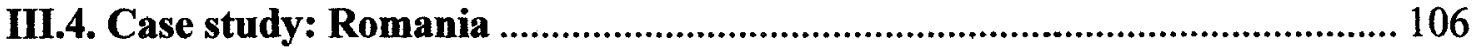

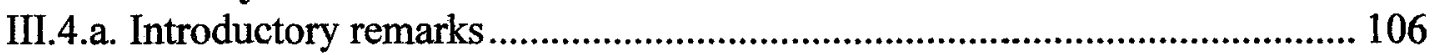

III.4.b. The Romanian perspective on the new security environment .................... 109

III.4.c. Post-9/11 security concerns in Romania................................................ 117

III.4.d. A "proactive" security and defence policy .............................................. 124

IV. The Transformation of Military Affairs........................................................... 134

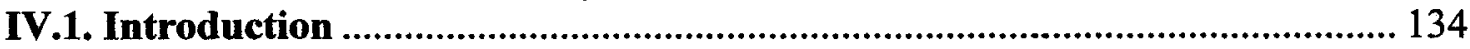




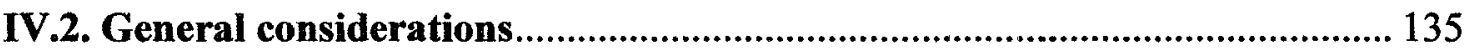

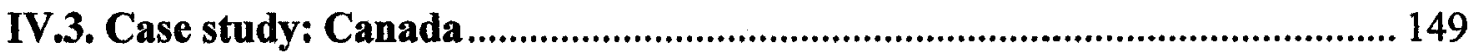

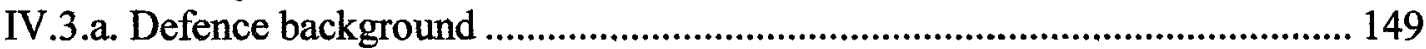

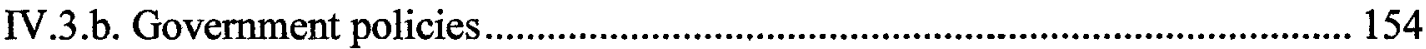

IV.3.b.i. 2005: The International Policy Statement ........................................... 155

IV.3.b.ii. 2004: The National Security Policy ....................................................... 159

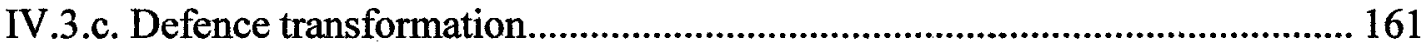

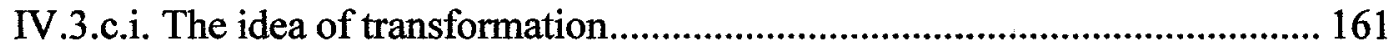

IV.3.c.ii. Developments in the transformation process......................................... 163

IV.3.c.iii. Transformation challenges ................................................................ 167

IV.3.d. Canada-United States defence relations ………........................................ 170

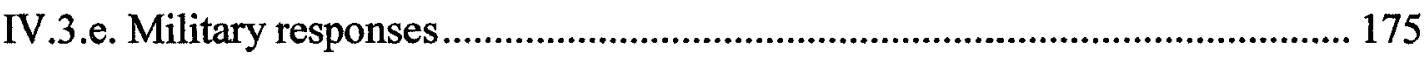

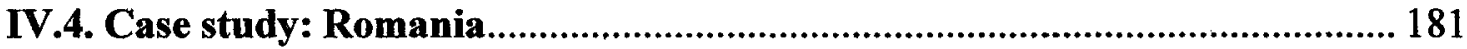

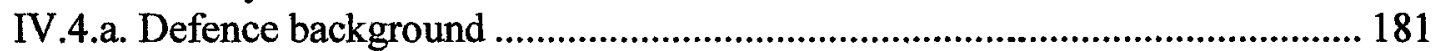

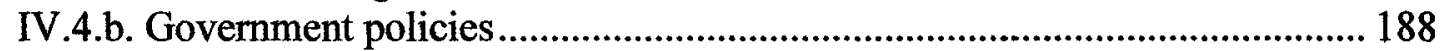

IV.4.b.i. 2006: The National Security Strategy ............................................... 190

IV.4.b.ii. 2004: The White Paper on Security and National Defence.................. 193

IV.4.b.iii. 2001: The National Security Strategy of Romania ............................. 195

IV.4.c. Defence transformation.............................................................................. 197

IV .4.c.i. The idea of transformation.................................................................. 197

IV.4.c.ii. Developments in the transformation process....................................... 199

IV.4.c.iii. Transformation challenges ......................................................... 203

IV.4.d. Romania-United States defence relations............................................... 205

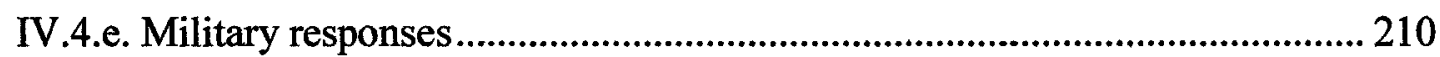

V. Patterns in Post-9/11 Civil-Military Relations ...................................................... 217

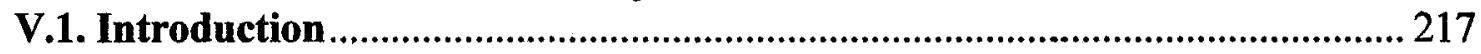

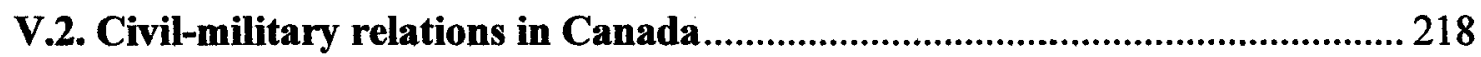

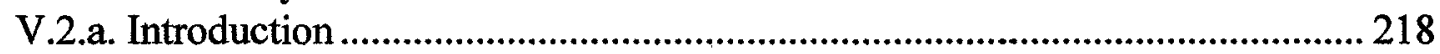

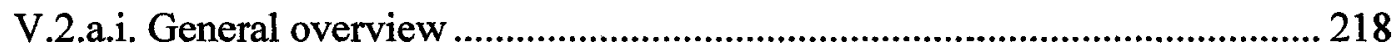

V.2.a.ii. Roles and functions............................................................................. 221

V.2.a.iii. Parliamentary oversight ......................................................................... 226

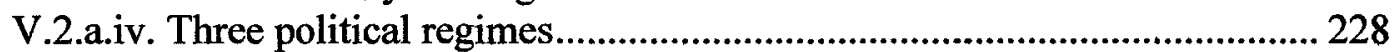

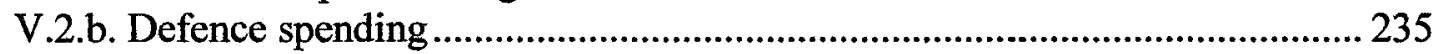

V.2.c. Government policies .................................................................................... 244

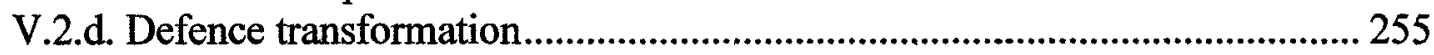

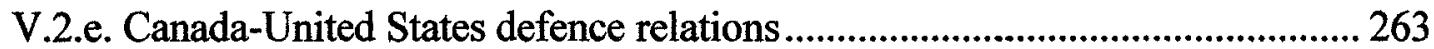

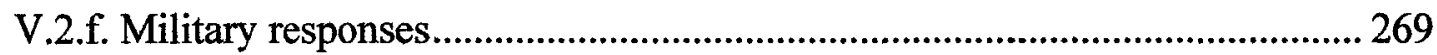

V.3. Civil-military relations in Romania........................................................... 278

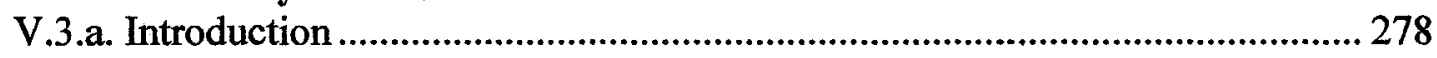

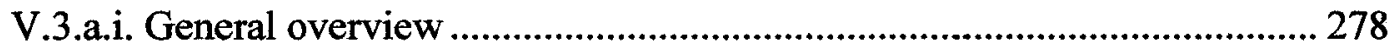

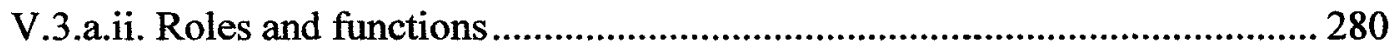

V.3.a.iii. Parliamentary oversight ..................................................................... 287

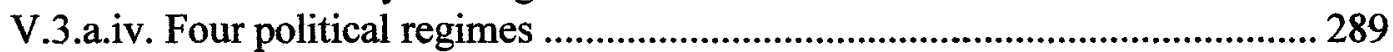

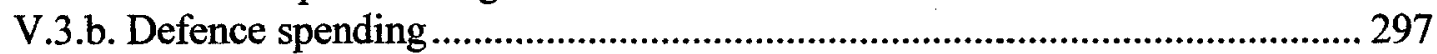

V.3.c. Government policies .................................................................................. 304

V.3.d. Defence transformation................................................................................. 311 
V.3.e. Romania-United States defence relations ....................................................... 318

V.3.f. Military responses............................................................................................. 324

V.4. Assessment of findings ...................................................................................... 330

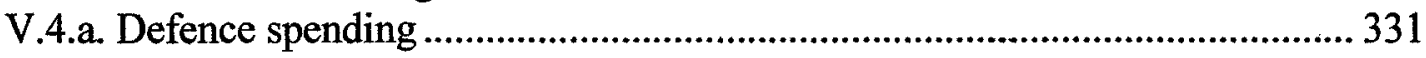

V.4.b. Government policies ...................................................................................... 332

V.4.c. Defence transformation..................................................................................... 333

V.4.d. Relations with the United States ................................................................ 335

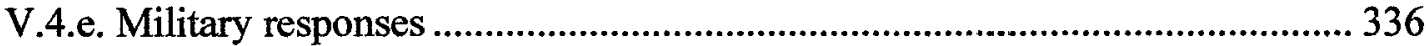

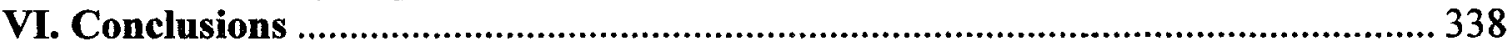

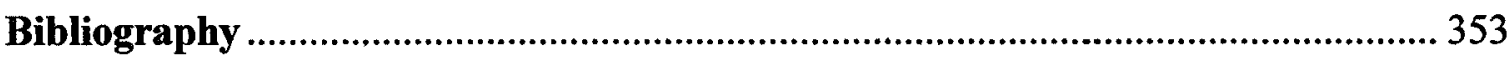

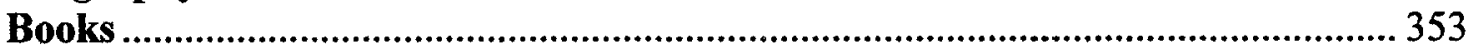

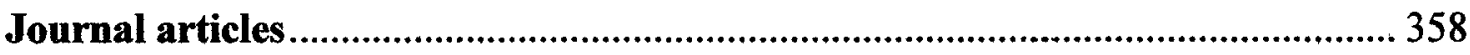

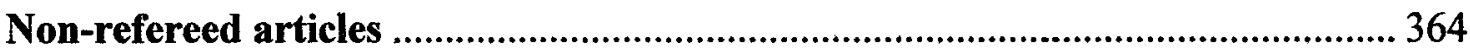

Primary sources and interviews ........................................................................... 272

Papers presented at professional meetings and conferences................................... 378 


\section{Introduction}

For several decades now, scholars have tried to shed light on the complex area of interaction between a state's civilian institutions and its armed forces (in the words of a

classic, between "the soldier and the state"). Civil-military relations as a subdiscipline of political science has a longer history in the United States (US) than in other countries, although researchers from around the world have contributed considerably to its development. Despite such effort, spanning across continents and dozens of years, the area remains rather under-theorized and largely unable to facilitate complex understanding and, if applicable, prediction of empirical developments.

The contribution that this thesis makes to the field is to investigate the correlation between threat environments and patterns of civil-military relations in Western countries, specifically following the terrorist incidents of September 11, 2001, against the United States of America (what would become known as the post-9/11 era). In particular, it tests the theory proposed by Michael C. Desch on the relationship between threat configurations and forms of civilian oversight over the armed forces, and provides evidence against its validity in the post-9/11 context. The indeterminate threat environment encountered during the period covered by this thesis (September 11, 2001September 11,2006$)$ does not fit closely any of Desch's categories. Using two case 
studies, Canada and Romania, and employing a most-different research design model, this thesis attempts to improve understanding of recent empirical developments in the area of civil-military relations in the West and to advance the theoretical debate in this field. ${ }^{1}$ During the five-year timeframe chosen for this study, the empirical evidence gathered from the two national contexts suggests that there were frequent instances of serious disagreement between civilian and military leaders.

This dissertation starts by providing a theoretical basis for the discussion of civil-military relations and by setting the terms of the analysis in following chapters - inter alia, detailing the basic assumptions in ontological, epistemological and methodological terms. The study proceeds by assessing the post-Cold War and post-9/11 threat environment in both general terms and in the context of the two case studies, Canada and Romania. Five key areas of interaction between civilian and military leaders are identified, which act as an interface between the independent variables (threat environments) and the dependent variables (patterns of civil-military relations). These intermediate variables proposed in the thesis are: (i) defence spending, (ii) government policies, (iii) defence transformation, (iv) relations with the United States of America and (v) military responses to the new threat environment. ${ }^{2}$

\footnotetext{
${ }^{1}$ More information on the choice of these two case studies to investigate civil-military relations in a Western context following the terrorist incidents of September 11,2001, as well as a brief exposé of Romania as a Western polity, will be provided in the following chapters of this thesis.

2 These variables have been selected - as elaborated upon later in the thesis - based on their appropriateness and potential to shed light on the subject matter for this dissertation, i.e., to reveal changes and patterns at the level of both independent variables (threat environments) and dependent variables (civilmilitary relations). They link analytically the broad changes in security configurations and strategic contexts to the resolution of conflicts between civilian and military leaders at national level.
} 
Alongside the assessment of threat configurations, the chapter focusing on the examination of patterns of interaction between senior civilian officials and top military leaders is of critical importance to this thesis. While the overall principle of civilian control over the armed forces was not openly called into question during the first five years of the post-9/11 era, the study revealed discordance between the two sides on the issue areas investigated in this dissertation. The concluding chapter of this thesis builds on these findings to offer a brief assessment of the current state of civil-military relations in Western countries and to advance succinct suggestions on a potentially fruitful research agenda in this field. It assesses the observed data and Desch's framework against the background of other theoretical constructs and offers a set of research recommendations meant to inform future work in the area of civil-military relations. Particularly in a context in which countries such as Canada or Romania were involved in military interventions overseas, being able to shed light on empirical developments relating to the interaction between "the soldier and the state" and to integrate the findings into a coherent theoretical framework is imperative.

The arguments made and the evidence presented in this dissertation will hopefully advance the theoretical conversation relating to civil-military relations and contribute to a new and improved stage in this field. While the thesis objective is to introduce the reader to a detailed discussion of the relationship between threat environments and patterns of civil-military relations, based on both empirical explorations and theoretical argumentation, the assessment of findings, provided in the final chapter, is meant to stimulate further investigation of these topics. 


\section{Theoretical Foundations and Methodological Approaches}

\section{II.1. Introduction}

This chapter provides a description of the theoretical standpoint adopted by this thesis; a detailed report of the methodological approaches to conducting this research study; an overview of the civil-military relations literature that forms the setting for this study's primary debates; and an account of the place of this study in the field and the contribution it makes to advancing understanding of patterns of interaction between civilians and the armed forces. The chapter sets the foundations for the ensuing arguments, debates and conclusions that are presented throughout this thesis; some of its propositions will be revisited in the final chapter, a framework that will not only provide unity to this thesis, but also offer a better understanding of the subject matter.

\section{II.2. Analytical statements and methodological framework}

\section{II.2.a. Main arguments}

This study argues and tries to provide evidence for the idea that there is a direct correlation between recent changes in national systems of civil-military relations, along 
similar lines, in the West and the threat environment. The research is timely and relevant, scholarly and policy-wise: the interaction between civilians and the military becomes critical in a context in which countries face levels of security threats that could endanger their political, economic and social stability. It thus becomes salient for scholars and other analysts to explore in-depth this area of interaction and possibly to identify conditions associated with improved civil-military relations.

Changes in patterns of civil-military relations take place primarily in national contexts (and have to be analyzed as such), yet for the purposes of this study systemic factors at domestic levels will not be approached as independent variables affecting civil-military relations. While acknowledging the significance of broad national factors and their potential impact on interactions between civilians and the military, this thesis attempts to demonstrate that the overall threat environment has the critical role in shaping civilmilitary relations (independent variable); systemic (national) factors will be analyzed as intermediate/intervening variables. The dependent variables in the context of this thesis are patterns of civil-military relations, as will be described in the following sections of this chapter.

The thesis is based on the assumption that it is the threat environment that has imposed on Canada and Romania, on Western countries in general, the need to adapt their security and defence structures and policies; consequently, it has shaped their patterns of civilmilitary relations, based on the requirements of responding to challenges after the end of the Cold War - particularly in the post-9/11 context. In his book Civilian Control of the 
Military: The Changing Security Environment, Michael C. Desch makes the case for a theoretical standpoint that is both comprehensive and parsimonious, arguing that "what stands behind these [national] variables are structural factors, such as the intensity of the domestic and international threat environments." ${ }^{33}$ This thesis tests his framework, using empirical evidence to evaluate its assertions, and will advance in Chapter VI novel hypotheses on the new nature of civil-military interaction. Building on this hypothesis, the framework proposed by Michael C. Desch in his book Civilian Control of the Military: The Changing Security Environment ${ }^{4}$ identifies specific links between security configurations and national civil-military relations after the end of the Cold War. This study argues that the nature of the post-9/11 security context does not allow for a clear differentiation between internal and external threats, which is one of the fundamental assumptions informing Michael C. Desch's framework.

The thesis also argues that the complex nature of threats such as terrorism, the proliferation of weapons of mass destruction and failed and failing states, as well as the equally complex substance of countries' responses to these threats strain civil-military relations to a significant extent. To support the idea of the changing configuration and perception of the security environment, the thesis examines both the nature of new threats and their intensity. Although the interaction between civilians and the military may improve in some respects when faced with security challenges, this study tries to disprove Michael C. Desch's theses that in this type of security environment, as a rule, the civilian leadership will be more "experienced in and knowledgeable about national security

\footnotetext{
${ }^{3}$ Michael C. Desch, Civilian Control of the Military: The Changing Security Environment (Baltimore and London: The Johns Hopkins University Press, 1999), 115.

${ }^{4}$ Ibid.
} 
affairs," that the military "will have less inclination to participate in domestic politics" and that "civilian and military ideas will tend to be in harmony."

While these patterns might have been identified in the context of the Cold War or in other historical contexts, this thesis attempts to demonstrate that the profound changes in military doctrines, operations and structures, and political responses necessitated by the nature of these new threats challenge Desch's model. The thesis is based on the key idea that the new threat environment leads in Western countries to the necessity of establishing new institutions and policies to deal with its challenges in appropriate ways, including novel strategies and military responses. These measures are necessary in order to allow the military to respond as effectively as possible to the new threats. Yet it is the transnational and asymmetrical nature of the post-9/11 security challenges that contradicts Desch's model, as it makes the differentiation between external and internal threats a very difficult, if no impossible, task.

Although terrorism and insurgent action are not new phenomena, the events of 9/11 have dramatically shaken the US security and defence establishment, and have sent shock waves around the world. In a context in which the armed forces assume new functions and pursue new strategies in the fight against terrorist and insurgent groups, the interaction between soldiers and statesmen acquires new dimensions as well. Closely related to the issue of terrorism are phenomena such as the proliferation of weapons of mass destruction, which could facilitate ever deadlier terrorist incidents, and failed and failing states, which could not only deteriorate the international security environment in a

\footnotetext{
${ }^{5}$ Ibid., 13-14.
} 
broader sense, but also act as breeding grounds for terrorist and insurgent networks. It is in this qualitatively new context that Rod Lyon of the University of Queensland notes, "Desch has shown us that security environments do shape civil-military relations. He has not shown us, in particular, how the War on Terror will shape them." identifies and presents the impact of the post-9/11 threat environment on systems of civilmilitary relations in Western countries.

\section{II.2.b. Research design}

This is a comparative politics study, based on a most-different-systems design: since domestic (systemic) factors shaping civil-military relations in a national context vary sharply from one country to the other (e.g., the political system, the structure of the security and defence establishment, military capabilities, national values and other such broad factors), they are an unlikely cause of similar recent evolutions in patterns of civilmilitary relations in the two cases (Canada and Romania). To assess these patterns, the thesis follows Michael C. Desch's suggestion of analyzing "who prevails when civilian and military preferences diverge... To determine whether the military plays an important role in a society's political decision-making, one should identify a number of issues that pitted military preferences against those of civilians and show who prevailed. ${ }^{.7}$ Michael C. Desch's approach to identify key areas of civil-military divergence and relevant examples, and analyze them in detail serves as an inspiration for this thesis - in Chapter

\footnotetext{
${ }^{6}$ Rod Lyon, "Civil-Military Relations in an Age of Terror," paper presented at the Australian-American Fullbright symposium Civil-Military Relations in an Age of Terror, organized by the University of Queensland, Brisbane (Australia), July 5-7, 2004.

${ }^{7}$ Ibid., 4-5.
} 
$\mathrm{V}$ the thesis lists five specific areas of civil-military interaction in both Canada and Romania and traces the outcome of possible conflicts: (i) defence spending, (ii) government policies, (iii) defence transformation, (iv) relations with the United States of America, and (v) military responses in the new security environment.

The study uses a comparative approach in order to underline patterns of interaction between civilian and military institutions in the countries analyzed and, by extension, in the West. Canadian and Romanian civil-military relations were selected as cases for this study because they fit the research design and presented the potential of leading to powerful and viable conclusions. By choosing a most-different-systems design, the thesis looks at Western cases that are different from each other and, at the same time, different from other countries, including the United States.

Canada's post-Cold War involvement in peacekeeping and other "soft" operations suggested not only specific functions assigned to its military establishment, which differentiated it from most others in the world, but also a significant deviation of the Canadian model of civil-military relations from the (US-based) traditional paradigm. The events of September 11, 2001 (but also other post-9/11 developments, such as the terrorist incidents of July 2005 in England) ${ }^{8}$ have led in Canada to organizational changes within various civilian and military sectors, to new policies designed to address the new

\footnotetext{
${ }^{8}$ On July 7, 2005, four bombs exploded in the London transit system, killing over 50 people and injuring hundreds of commuters. Two weeks later, on July 21,2005 , four other bombs partially detonated in the London transit system, injuring one person. The terrorist attacks have been attributed to radical Islamic terrorist groups, some of whose members are thought to have attended terrorist camps in Pakistan and possibly other countries. The London attacks triggered a new set of anti-terrorist measures in the United Kingdom, but also in other Western countries, including Canada and Romania: inter alia, heightened levels of vigilance and increased police presence on underground and surface transit systems in larger metropolitan areas, but also stronger commitment to external military missions.
} 
threats (e.g., a partial move from peacekeeping to warfare) and to a climate of uncertainty about the best course of action domestically and externally in the new security environment. Although the impact of US military policies and actions on Canada's military decisions has always been considerable, in the post-9/11 context Canada has struggled to find its own response to these new security challenges.

Romania's armed forces are representative of Eastern European militaries, which had to dramatically redefine their functions in the post-Warsaw Pact context. In the case of Romania specifically, the move from defence based almost exclusively on national means to multinational cooperation within Western structures meant a profound transformation of its defence institutions, security doctrines and military strategies. At the same time, the systemic transformations taking place in Eastern European countries such as Romania since the early 1990s produced noticeable changes in civilian structures and policies employed in military oversight. In the post-9/11 context, Romania intensified its participation in international operations (mostly as part of US-led missions) and increased the tempo of transforming its armed forces according to the requirements of the new international security environment and the country's own political goals of Western integration; it also saw genuine domestic debate on security and defence objectives distinct from the guidelines provided by the North Atlantic Treaty Organization (NATO) or the United States.

In a groundbreaking study on the adoption of Western norms by Eastern European countries following the end of the Cold War, Piotr Dutkiewicz and Sergei Plekhanov 
focus specifically on the area of civil-military relations as "an especially persuasive study of the politics of mimicry." This paradigm suggests that, in most of these countries, "what started as mimicry under (mostly) external pressure [...] began to live its own, independent life and influenced [...] much deeper changes than many observers anticipated." ${ }^{\prime 9}$ Other studies of Romania's post-Cold War adoption of Western norms in the area of civil-military relations provide a counterintuitive argument, indicating limited or uncertain levels of influence exercised by external actors, NATO included. They suggest that domestic actors (civilian and military) in post-Communist Romania pursued defence transformation and the idea of accession to the Atlantic Alliance to the extent that those objectives became compatible with their interests and available means.

Rachel A. Epstein, for instance, argues that "NATO has significantly contributed to the transformation of [E]astern European military cultures by promoting democratic control over the armed forces and by linking domestic values to external security strategies," yet Romania, along with Bulgaria and Slovakia, show particular characteristics. An analysis of the three cases indicates "formidable barriers to rapid political convergence with the [A]lliance," in the Romanian context among other factors given the country's history of military independence (from the Warsaw Pact and other multinational structures) from the 1960 s onwards. ${ }^{10}$ While acknowledging the rich and intricate theoretical debate on the transfer of norms, rules and procedures by external actors in Central and Eastern European countries during the post-Cold War era, this thesis will treat Romania as a

\footnotetext{
${ }^{9}$ Piotr Dutkiewicz and Sergei Plekhanov, "The Politics of 'Mimicry': The Case of Eastern Europe," in The Soldier and the State in the Post Cold-War Era, ed. Albert Legault and Joel Sokolsky, a special issue of the Queen's Quarterly (2002), 114.

${ }^{10}$ Rachel A. Epstein, "NATO Enlargement and the Spread of Democracy: Evidence and Expectations," Security Studies, vol. 14, no. 1 (January-March 2005), 105.
} 
Western country, comparable with other NATO member states on security and defence issues during the post-9/11 era (yet recognizing differences in the process of defence transformation between this country and its Western partners).

In a different study on democracy and civil-military relations, Andrew Cottey, Timothy Edmunds and Anthony Forster argue that in Romania, along with a few other Eastern European countries (Bulgaria, Croatia, the Czech Republic, Estonia, Hungary, Latvia, Lithuania, Poland, Slovakia and Slovenia), "[f]irst generation issues of civil-military reform have largely been addressed."11 Their assessment indicates that these countries reached, after a period of transition, a state where their model of civil-military relations conforms relatively closely to traditional Western standards. Cottey, Edmunds and Forster point out that "problems still exist," mainly related to intra-civilian disagreements over defence and security matters, to attempts by civilians to use the armed forces for partisan political purposes and to "issues of democratic consolidation, effectiveness, and efficiency $[\ldots]$ in areas such as defense planning, control of the defense budget and parliamentary oversight." ${ }^{\text {12 }}$ Overall, however, their adoption of typical Western standards in the field of civil-military relations was completed and all these countries (except Croatia) became members of the North Atlantic Treaty Organization and the European Union (EU). ${ }^{13}$

${ }^{11}$ Andrew Cottey et al., "The Second Generation Problematic: Rethinking Democracy and Civil-Military Relations," Armed Forces \& Society, vol. 29, no. 1 (Fall 2002), 49.

${ }_{12} \mathrm{lbid}$.

${ }^{13}$ In a second group of Eastern European and former Soviet countries (Russia and Ukraine), "[f]irst generation problems still exist, despite some democratization of civil-military relations and politics more widely," while in a third group (Belarus, Kazakhstan, Kyrgyzstan, Serbia-Montenegro, Turkmenistan and Uzbekistan) "[f]irst generation democratization of civil-military relations has not yet occurred." Finally, in a fourth group (Albania, Armenia, Azerbaijan, Bosnia-Herzegovina, Georgia, Macedonia, Moldova and Tajikistan), "[b]oth first and second generation civil-military reform have been stalled by the weakness of 
Occasionally, throughout the thesis the two cases are compared with the United States, today's only military superpower; the USA is, moreover, the Western country that has felt in the most dramatic way, on September 11, 2001, the dreadful impact of international terrorism and has probably gone further than any other on the path of changing policies and reforming institutions, in order to more effectively deal with the new threat environment. However, it is for these very same reasons that the USA was not selected as a third case for this study, as it stands as the obvious exception, rather than the rule, among Western countries. Its special status in world affairs and the tautological character of an attempt to demonstrate the obvious link between the global threat environment (e.g., terrorist threats) and the US reaction to it would have undermined the validity of the research design for this thesis.

The events of September 11,2001, have dramatically changed the perception of threats in the USA and in the West more generally (including Canada and Romania) and have led to new policies for military action and new organizational structures to perform security and defence operations. Consequently, in the post-Cold War and the post-9/11 context specifically, the interaction between the civilian and military leadership was significantly altered. Although there is anecdotal evidence supporting the idea of these changing relationships, no systematic study seems to have been completed to date; this area of research has been overlooked in the civil-military relations literature and this study contributes to filling that theoretical gap. At the same time, the thesis is policy-relevant,

the state." For more details on these cases and on the methodology used for this study, see: Andrew Cottey et al., 50-51. 
since it can offer a better understanding of the impact of security configurations on mechanisms of interaction between civilian and military institutions.

Canada and Romania are two Western cases clearly distinct from each other in the area of defence policies and institutions; yet both offer in the post-Cold War and especially the post-9/11 period a similar model of dealing with the new international context, through the transformation of their military establishments' functions and structures, and the alteration of their systems of civil-military relations along similar lines. No non-Western cases were chosen, as this study attempts to evaluate the nature of the changing patterns of civil-military interaction in a Western environment; the specificity of non-Western civil-military relations would have rendered the study unreasonably complicated.

To further narrow down the scope of the case studies, this thesis explores to a significant degree the involvement of Canadian and Romanian armed forces in post-2001 missions in Afghanistan and Iraq, particularly the former. This constitutes a litmus test, revealing changes in military functions and responses, defence institutions and policies, and patterns of civil-military relations. The argumentation for this thesis is based on aggregation of comparable qualitative data found in the realm of Canadian and Romanian civil-military relations; the security environment and its constraints on countries' military and political options and actions will be investigated as independent variables.

The essence of the topic chosen for this study (policies and institutions relating to armed forces and national security) solves to a large extent what is known as Galton's 
Problem, ${ }^{14}$ since these areas are some of the last remaining bastions of national sovereignty. This fact would only underscore the importance of the study's findings, since it would provide evidence for the hypothesis that similar outcomes have been obtained through mostly independent national decision-making processes, yet enabled by a new security environment. The cases chosen are not only independent units, for no government willingly agrees to delegate or renounce authority on such important issues, but also very different from each other in systemic terms.

While some countries' reforms and changes in the defence arena could influence those of other countries, via the demonstration effect, this process would not undermine the validity of this study's findings. Analyzing this particular process is beyond the scope of this study, whose dependent variables are located within national boundaries; interactions between similar actors located in different national arenas (e.g., military-to-military ties, regular diplomatic relations, etc.) are seen in the context of this study as intermediate or intervening variables that do not affect in a significant way the impact of structural factors, especially threats, on countries' civil-military communities taken individually. Countries' bilateral and multilateral relations can become topics of heated discussions in national contexts (e.g., debates on the scope of security and defence cooperation with the United States), yet the underlining factors fuelling such situations are assumed to be related to structural conditions (i.e., the threat environment, in the context of this thesis).

\footnotetext{
14 "Galton's problem is considered a crucial weakness in the cross cultural survey method [...] traits often spread by diffusion, by borrowing, or migration." For more details on Galton's Problem see: Raoul Naroll, "Galton's Problem," in Handbook of Method in Cultural Anthropology, ed. R. Naroll and R. Cohen (Garden City, NY: Natural History Press, 1970).
} 


\section{II.2.c. Research methods}

The study is based on the use of qualitative methods, by focusing on policies and institutions in the two national contexts. On the one hand, it analyzes the general provisions of legal and customary frameworks concerning civil-military relations in the two cases. On the other hand, it studies formal and informal relations between different structures having responsibilities for security and defence matters in Canada and Romania. It assesses patterns of interaction between civilian authorities and armed forces, by attempting to isolate the impact of a new threat environment (used here as independent variables) on civil-military relations (the dependent variable).

The research, meant to be explanatory, is based on a combination of multiple research strategies, such as comparative analysis and case studies. It is devoted to investigating the causal relations between factors associated with the post-Cold War (particularly post9/11) threat environment and the achievement of a particular set of patterns of civilmilitary interaction at national level. The thesis is based on the use of both primary sources (laws, interviews, speeches, government reports, etc.) and secondary literature in several languages (English, Romanian and French). A large part of the evidence used are interviews already published, either in mass media or in specialized journals, and official speeches and legal documents. Some of the primary documents are analyzed in-depth, as a content study can provide support to this dissertation's main propositions. Being a comparative study, the documents analyzed include comparable sources from Canadian 
and Romanian cases. Its goal is to have equivalent measures in order to assess convincingly the importance and significance of the empirical findings.

The research is also testable: observation and analysis of policy changes, institutional reorganization and repeated or regular ways in which civilian and military leaders interact in case of divergence of opinion provide evidence for this study's hypotheses. Patterns of civil-military relations can be detected by observing modifications in policies, institutions and individual/group interactions, and through the interpretation put on these findings by practitioners and other experts. This latter aspect is closely related to the imperative of defining the key concepts to be employed in a study - otherwise, the research would be of little use to a field divided over various definitions and meanings, as reflected in the civil-military relations literature. This study uses "nominalist"15 approaches in defining key concepts, the most important of which are the civilian and military spheres that constitute the ontological basis of the field of civil-military relations. Other key concepts,

\footnotetext{
${ }^{15}$ The problem of definitions and of the "meaning of terms" has been, according to Karl Popper, "an inexhaustible source of confusion and of [a] particular kind of verbiage," which "has bread that poisonous intellectual disease of our own time" that he called "oracular history." By trying to use the so-called "essentialist method of definitions" of Aristotle (i.e., trying to acquire encyclopaedic knowledge to determine the meaning of concepts), social scientists have proven to be on the wrong track. They have "remained arrested," Karl Popper argued, "in a state of empty verbiage and barren scholasticism." Using Aristotle's doctrine of definitions - Popper pointed out - philosophers and social scientists have begun to feel that one could not argue about definitions. This situation seems to have led to "disillusionment with argument" and "despair in reason" (Karl Popper, The Open Society and Its Enemies. Vol. II. The High Tide of Prophecy. Hegel and Marx (London: Routledge \& Kegan Paul Ltd., 1957), 9 and 21). A solution to this apparently unsolvable problem has been offered by "the nominalist form of inquiry," as Yossi Shain puts it, i.e., the adoption of operational, short definitions for various concepts. Nominalism, Yossi Shain points out, "calls for the adoption of operational definitions, 'handy shorthand labels' responding to the question 'What shall we call X?' instead of 'What is X?'. Such denotations can help social science to overcome vagueness, ambiguity, and infinite regression, which are the logical delight of ideologies that defy reason" (Yossi Shain, "Minimum Claims, Maximum Gains: The Advantages of Juan Linz's Definition of Democracy," in Politics, Society, and Democracy. Comparative Studies, ed. H.E. Chehabi and Alfred Stepan (San Francisco: Westview Press, 1995), 45).
} 
such as "terrorism" or "weapons of mass destruction," are defined in a similar manner in the next chapters.

In looking at civil-military interactions, this thesis uses what Daniel N. Nelson calls "narrow" definitions of "civil" and "military." According to his article titled "Definition, Diagnosis, Therapy: A Civil-Military Critique," a "narrow" definition of "civil" is, "principal national government institutions and occupants of those posts," and a "broad" definition is, "the public sphere, including civil society, all governmental institutions, and popular opinion." Also, "military" can be defined in a "narrow" sense as "the military officer corps" and in a "broad" sense as "all national security structures plus socioeconomic and political allied or intertwined institutions and groups." While Nelson argues that "only with a broad definition of both 'civil' and 'military' can we encompass the scope and complexities of a post-Cold War environment increasingly affected by transnational and global trends,"

It proposes a model based on the analysis of the interaction between the leadership of main military and political institutions, which can advance coherent empirical analysis and parsimonious theoretical development in this area more effectively. Including all variables that can be identified in relation to a subject, as Nelson does, is a research strategy that seems to run counter to his declared goal, of fixing the problem of undertheorizing in the civil-military relations literature. By main military institutions it is understood in this context the army, the navy, the air force and their Defence/General

${ }^{16}$ Daniel N. Nelson, "Definition, Diagnosis, Therapy: A Civil-Military Critique," Defense \& Security Analysis, vol. 18, no. 2 (2002), 161. 
Staff; therefore, paramilitary structures or militarized types of police, gendarmerie, border guards and other similar institutions are not included under the umbrella of "armed forces" or "military." For main political institutions this study adopts a definition of the civilian sphere proposed by Douglas L. Bland: the organizations represented by "elected civilians who by constitution, law, and custom [...] are responsible and accountable to the sovereign people. ${ }^{p 17}$

The choice for these research methods and for the accompanying research design presents the potential to advance not only a better empirical understanding of the complex area of civil-military relations, but also improved formulation of theoretical statements for this field. This methodological framework is meant to clearly define the scope and the terms of the debates and arguments presented in the following chapters of this thesis, which is essential for a coherent academic analysis of any area of research. It is fully compatible with methodological approaches employed by other civil-military relations studies; beyond that, it tries to contribute to creating and consolidating theory that is clearer and more parsimonious, and has a stronger connection to empirical developments.

\footnotetext{
${ }^{17}$ Both spheres can be conceptualized in broader terms as well: the civilian sphere can encompass both elected officials and "appointed professional public or civil servants," while the military sphere can be seen as a defence establishment that includes "any military person, public or civil servant, scientist, or others (but not members of the civil authority) who are primarily employed within the armed forces or government departments and ministries and who are directly responsible for commanding and controlling the military and/or managing defence policy and resources" (Douglas L. Bland, "Patterns in Liberal CivilMilitary Relations," Armed Forces \& Society, vol. 27, no. 4 (Summer 2001), 532).
} 


\section{II.3. The place of the study in the civil-military relations literature}

Most students of civil-military relations recognize not only that their field is undertheorized, but also that trying to devise an overarching theory of interaction between civilians and armed forces is a virtually impossible endeavour. Although the history of this field has witnessed such attempts, the recent literature has taken a more humble approach, scholars acknowledging their limits in covering the very large and eclectic area of civil-military interaction. The solution, embraced by a majority of Western scholars, has been to narrow down the subject matter to a manageable area of study, which is generally seen as the interplay between political and military leaders within a domestic (national) environment. As James Burk explains further, "[t] $t$ he question raised is whether (or to what degree) uniformed military elites follow the commands of civilian political elites." $" 18$

Most civil-military relations theoretical frameworks, still employed in the study of the field today, were proposed at the beginning of the Cold War in Western countries, especially in the United States. However, as Harald von Riekhoff points out, some of the concerns driving the efforts of building theory in this field and informing it at the time have largely dissipated, e.g., a "central preoccupation [...] with coups d'état, especially in Latin America" and "the challenge of managing the colossal military establishment of a

\footnotetext{
${ }^{18}$ James Burk, "Theories of Democratic Civil-Military Relations," Armed Forces \& Society, vol. 29, no. 1 (Fall 2002), 7.
} 
nuclear superpower, having the United States in mind. ${ }^{, 19}$ More recent frameworks have contributed to fine-tuning these "classic" theories, but have not yet managed to replace them. Steps toward revamping the theories underlying the field of civil-military relations are encouraging and will be reviewed later in the chapter.

What unites both old and new theories is, nonetheless, a solid normative belief in the supremacy of civilians over the military, in line with democratic principles that Western countries are based upon. What this means in the area of interplay between civilians and armed forces, Peter D. Feaver argues, is that "the hierarchy of de jure authority favors civilians against the military, even in those cases when the underlying distribution of de facto power favors the military. ${ }^{, 20}$ This is because there exists in the West a large degree of uneasiness about allowing an institution such as the military - undemocratic by its very nature - to exercise power in its own right. Therefore, to the extent that civilmilitary relations theory is concerned, "it seems that the central problem [...] is to explain how civilian control over the military is established and maintained."21

A corollary of the normative assumption that civilians have primacy in their relations with the military is that government decisions should be implemented by the armed forces even in those instances when following such a course of action seems unwise. As Peter D. Feaver compellingly puts it, "[c]ivilians should get what they ask for, even if it

\footnotetext{
${ }^{19}$ Harald von Riekhoff, introduction to The Evolution of Civil-Military Relations in East-Central Europe and the Former Soviet Union, ed. Natalie L. Mychajlyszyn and Harald von Riekhoff (Westport: Praeger, 2004), 6.

${ }^{20}$ Peter D. Feaver, "The Civil-Military Problematique: Huntington, Janowitz, and the Question of Civilian Control," Armed Forces \& Society, vol. 23, no. 2 (Winter 1996), 153.

${ }^{21}$ James Burk, "Theories of Democratic Civil-Military Relations," 7.
} 
is not what they really want. In other words, civilians have a right to be wrong."22 The explanation for this position, which may appear at first sight unreasonable, is that the government in a democratic society is the legitimate expression of people's will. Therefore, while the military is offered an area over which its authority is traditionally unchallenged by civilians (e.g., specific arrangements in theatres of operations), "the 'ought' remains the prerogative of the political power.,

At the same time, in order for the civil-military relationship to function and for civilian leaders to avoid the dangers of military coups (or at least heavy military interference in political affairs), the government must be attentive to armed forces' needs. Along with refraining from micro-managing the military, "the government must fulfill its part of the bargain by giving [the armed forces] the resources needed to perform the specific tasks assigned to it by the policymakers. ${ }^{.24}$ James Burk adds to this a government obligation to devise mechanisms ensuring military control over civilian contractors. ${ }^{25}$ It is, after all, in the best interest of civilian leaders to temper possible authoritarian tendencies of an institution that has control over most legitimate means of violence in society and to provide it with the best means of carrying its appropriate tasks. In other words, the question is how "to reconcile a military strong enough to do anything the civilians ask them to do with a military subordinate enough to do only what civilians authorize them to do. ${ }^{26}$

\footnotetext{
${ }^{22}$ Peter D. Feaver, "The Civil-Military Problematique," 154.

${ }^{23}$ Albert Legault, "Civil-Military Relations: Democracy and Norm Transfer," in The Soldier and the State in the Post Cold War Era, ed. Albert Legault and Joel Sokolsky, 21.

${ }^{24}$ Andrew A. Michta, The Soldier-Citizen: The Politics of the Polish Army after Communism (New York: St. Martin's Pres, 1997), 8.

${ }^{25}$ James Burk, "Theories of Democratic Civil-Military Relations," 23.

${ }^{26}$ Peter D. Feaver, "The Civil-Military Problematique," 149.
} 
The likelihood of military intervention in domestic politics is suggested in the West by armed forces' propensity to shape state policy on defence and security matters. Many authors argue that this is a litmus test of a country's close adherence to what is perceived as the Western model of civil-military relations, according to which policy making is the attribute of political, not military leaders. Kenneth W. Kemp and Charles Hudlin see this aspect of civilian control over the military in the West as having two parts: "[f]irst, the ends of government policy are to be set by civilians; the military is limited to decisions about means" and, "second, it is for the civilian leadership to decide where the line between ends and means (and hence between civilian and military responsibility) is to be drawn. ${ }^{27}$ This line is decided by civilians even in cases in which the subject matter concerns directly issues such as disposition of military units domestically and deployment of armed forces externally. In empirical terms, however, in most Western countries, the interaction between civilians and armed forces does not conform perfectly to the prescriptions of the classic model of civil-military relations.

Yet, even when the military as an institution and its top leaders enter the political debate to advance one position or another, there is the normative expectation of their not supporting overtly particular political forces. There is a wider acknowledgement today (than at the time of the first civil-military relations theories being drawn) that political neutrality of the military is an unreasonable expectation. Indeed, as Morris Janowitz pointed out decades ago, "[f]or it to be neutral would, in effect, mean that military

${ }^{27}$ Kenneth W. Kemp and Charles Hudlin, "Civil Supremacy over the Military: Its Nature and Limits," Armed Forces \& Society, vol. 19, no. 1 (Fall 1992), 8-9. 
personnel were no more or less than hired mercenaries. [...] Too often, political neutrality in the military is disguised opposition to democratic principles." ${ }^{28}$ What students of civil-military relations advocate, instead, for the armed forces is adherence to democratic principles, but non-involvement in partisan domestic politics.

As individuals, regular members of armed forces can, of course, exercise their political rights as part of a democratic system (to the extent that their institution or their leaders are not perceived, or do not act, as embracing a particular position in the day-to-day domestic political debates). Otherwise, as Harald von Riekhoff underlines, the military "is hardly apolitical in the sense of being excluded from the policy process;" while advancing a position or another, the military "may easily become enmeshed in partisan political debates" and, in those situations, von Riekhoff's prescription is "[to confine] such bargaining to closed doors. ${ }^{, 29}$ To many unfamiliar with the field of civil-military relations the prescription may sound peculiar, since it would not change much in the substance of interplay between civilians and armed forces.

However, this prescription can be explained by the environment in which the interaction takes place, one based on the above-mentioned assumption that the military should be as "neutral" as possible. A corollary of this is the normative position that armed forces "not be seen (nor see themselves) as a separate constituency whose interests are to be considered in policy debates. ${ }^{30}$ Even in those cases in which the military does not

\footnotetext{
${ }^{28}$ Morris Janowitz, The Military in the Political Development of New Nations: An Essay in Comparative Analysis (Chicago and London: The University of Chicago Press, 1964), 101-102.

${ }^{29}$ Harald von Riekhoff, introduction, 4.

${ }^{30}$ Kenneth W. Kemp and Charles Hudlin, "Civil Supremacy over the Military," 9.
} 
attempt to promote specific interests, this places the armed forces in the uncomfortable position in which it is their duty to offer expertise on security and defence matters, but their obligation as well to make sure the advice offered to civilians is not perceived as politically partisan.

The theoretical debate and empirical interaction between government and armed forces is complicated by significant areas of overlap between the functions/responsibilities of civilian and military institutions. In a study of national security decision-making processes, Christopher P. Gibson and Don M. Snider define the traditional sphere of civilian officials as consisting of functions and responsibilities related to national strategy, national resources, political objectives and declarations of war. The sphere of military leaders would be concerned with military doctrines and tactics, military training, military objectives and war fighting.

Gibson and Snider see the area of overlap and possible tension as gravitating around military roles and missions, and rules of engagement. Yet, despite their relatively clear classification, Gibson and Snider recognize that, "increasingly since the end of the Cold War, some [issues] fall in an overlapping area of joint responsibility. ${ }^{.31}$ Albert Legault argues that, "[i]n reality, most, it not all, major strategic decisions are made after close consultation with military authorities"32 and an increasing number of authors point out

${ }^{31}$ Christopher P. Gibson and Don M. Snider, "Civil-Military Relations and the Potential to Influence: A Look at the National Security Decision-Making Process," Armed Forces \& Society, vol. 25, no. 2 (Winter 1999), 195.

${ }^{32}$ Albert Legault, "Civil-Military Relations," 21. 
that areas of overlap between civilian and military responsibilities are widening in the context of the new war against international terrorist and insurgent forces.

In operational terms, the traditional Western model of civil-military relations is generally thought to be based on a set of a few key characteristics: (i) a relatively clear legal and/or institutional framework regulating the relationship between civilian authorities and the military; (ii) a democratic political system, providing the mechanisms to ensure the free expression of people's will in a majority of situations and to facilitate public scrutiny of military actions; (iii) a military recognizing the legitimacy of the political system and the rule of law, and acknowledging the need for its own political neutrality (or, at least, nonpartisan involvement in politics) as an institution; (iv) the subordination of the armed forces (i.e., the Defence/General Staff) to the Government, through a civilian-led Department/Ministry of (National) Defence, and to the civilian Head of State (i.e., a clear chain of command, with civilian leaders at the top), and a significant role for Parliament in making decisions on defence (especially budgetary) issues; and (v) the existence of an active civil society, involved in a public debate on security and defence matters. ${ }^{33}$ The latter feature is seldom used in civil-military relations theories, although the scholarly literature employs this characteristic of a Western society as a background condition for the actual interaction between political leaders and armed forces. ${ }^{34}$

\footnotetext{
${ }^{33}$ For a more detailed discussion of the traditional Western/liberal model of civil-military relations and its differences from a Communist/authoritarian model, see: Dragos Popa, "Civilian Control over the Military in Bulgaria and Romania (1989-2004)," in Transforming National Armed Forces in South East Europe: From the Social to the Military Challenge, ed. Ernst M. Felberbauer et al. (Vienna: National Defence Academy and Bureau for Security Policy, 2005), 82-83.

${ }^{34}$ Throughout this study the concepts of "control" and "oversight" of the armed forces will be used interchangeably. Harald von Riekhoff (introduction, 4) suggests that terms such as civilian "supervision," "direction" or "primacy" can be used alongside "control." The field of civil-military relations seems to
} 
The following sections will look at the most important civil-military relations theories, which together form the theoretical background against which the empirical analysis will be pursued as part of the thesis. Such a review is particularly useful, Peter D. Feaver notes, since "[o]ne of the weaknesses in the civil-military relations literature is that there are relatively few efforts to systematically compare explanatory factors or to identify the conditions under which one set of factors has more explanatory leverage than another."35 Key theoretical positions will be revisited in the final chapter (Conclusions), in light of empirical findings.

\section{II.3.a. Carl von Clausewitz}

Contrary to common belief, serious debate on civil-military relations issues did not take off with Samuel P. Huntington's opus The Soldier and the State, although Huntington's work continues to be the most recognized contribution to this literature. As early as midnineteenth century, the Prussian general and military thinker Carl von Clausewitz had offered a solid basis for discussion of the interaction between the statesman and the military commander, through his classic $O n$ War. ${ }^{36}$ Since the book's first publication, one of its key ideas, according to which "war is a mere continuation of policy by other

have given preference to the latter, despite a meaning that seems to be perceived by many as "excessively technical and narrow in scope."

${ }^{35}$ Peter D. Feaver, "Civil-Military Relations," Annual Review of Political Science, vol. 2, no. 1 (1999), 224.

${ }^{36}$ Carl von Clausewitz, On War (New York: G. P. Putnam's Sons, 1967). 
means, ${ }^{, 37}$ has sparked endless arguments about its meaning and the proper mix of civilian and military involvement in major military developments.

Clausewitz implied that civilian authorities and military establishments should be distinct from each other and that commanders be subordinated to statesmen: "[i]f war belongs to policy, it will naturally take its character from thence. ${ }^{.38}$ He underlined that purely military decisions are not only unacceptable, but also damaging: "[t]he subordination of the political point of view to the military would be contrary to common sense, for policy has declared the war; it is the intelligent faculty, war only the instrument, and not the reverse. ${ }^{39}$ What is often overlooked, nevertheless, is his acknowledgment that the lines of responsibility between civilians and the military are normally blurred.

Clausewitz recommended that, in most cases, policy not "[s]ink deep into the details of War. Sentries are not planted, patrols do not make their rounds from political considerations. ${ }^{, 40}$ But in a context in which the objectives in a military conflict are other than the unqualified destruction of the enemy's armed forces, even tasks traditionally assigned to military commanders tend to acquire increasingly political connotations. Overlapping of understanding and responsibility between civilians and the military on most key issues related to armed forces thus seems to be Clausewitz's response to questions about the limits of their areas of competence.

\footnotetext{
${ }^{37} \mathrm{Ibid} ., 57$.

${ }^{38}$ Ibid., 216.

${ }^{39}$ Ibid., 217.

${ }^{40}$ Ibid., 216.
} 
The statesman can have a say even on operational details - "[s]mall as it is [his] influence in this respect, it is great in the formation of a plan for whole War, or a campaign, and often even for a battle"41 - but he is supposed to understand the instrument he employs in advancing political goals: "[a] certain knowledge of the nature of War is essential to the management of political intercourse. ${ }^{, 42}$ At the same time, the military commander must also act like a statesman and, along with his civilian masters, must "[u]nderstand in this respect the War in which he engages, not $[\ldots]$ take it for something, or $[\ldots]$ wish to make of it something, which by the nature of its relations it is impossible for it to be.,"43

Most of contemporary literature on civil-military relations, including Michael C. Desch's framework, has tended to emphasize the importance of a clear separation between the realms of civilian authorities and of armed forces, a model that has been given increasing prominence after the publication of Samuel P. Huntington's The Soldier and the State. It is a rather recent trend in academic circles to rediscover and explore a Clausewitzian model of civil-military interaction, based on civilian supremacy, but also on partially shared civilian and military responsibilities and knowledge on strategic, operational and even tactical decisions.

\section{II.3.b. Samuel P. Huntington}

More than a century after the first edition of On War was published, Huntington's The Soldier and the State was set to become the reference study in the under-theorized field

\footnotetext{
${ }^{41} \mathrm{Ibid}$.

${ }^{42}$ Ibid., 218.

${ }^{43}$ Ibid., 59.
} 
of civil-military relations. While sometimes adding new nuances to the Clausewitzian narrative, Huntington's book distorted the Prussian general's message, according to which the politico-military interplay at various levels is a fact of life, in other words, it is normal. Huntington's model is based on two types of civilian control over the military one desirable ("objective civilian control"), the other less so ("subjective"). The former is conceived as the situation in which military professionalism is maximized, based on a clear separation between civilian and military responsibilities.

In Huntington's view, this situation - in which the military runs its own affairs and abstains from involvement in politics, while the civilian authorities do not interfere in the armed forces' own area of expertise - improves military competence and the prospect of civil-military harmony. "More precisely, it is that distribution of political power between military and civilian groups," he argues, "which is most conducive to the emergence of professional attitudes and behavior among the members of the officer corps.”44 The latter type of civilian control ("subjective") presupposes maximizing the power of civilians in relation to the armed forces, which presents the potential of undermining the security of the state.

Huntington points out that using institutional frameworks, rigid social hierarchies or legal mechanisms with the aim of increasing the influence of civilians vis-à-vis the military is, or ought to be, an obsolete practice in the West. "Subjective civilian control," he argues, "achieves its end by civilianizing the military, making them the mirror of the state.

\footnotetext{
${ }^{44}$ Samuel P. Huntington, The Soldier and the State: The Theory and Politics of Civil-Military Relations (Cambridge, MA: Harvard University Press, 1967), 83.
} 
Objective civilian control achieves its end by militarizing the military, making them the tool of the state." ${ }^{45}$ Peter D. Feaver argues that Huntington's framework can be reduced to three core claims: "there is a meaningful difference between civilian and military roles," "the key to civilian control is professionalism" and "the key to professionalism is military autonomy. ${ }^{, 46}$

Critics of Huntington's work wonder why the author has not detailed a third possible situation, alongside objective and subjective control, in which civilian and military responsibilities overlap to a significant extent. It was, after all, Huntington who underscored one of the most important principles of contemporary civil-military relations, when he argued that "the problem in the modern state is not armed revolt but the relation of the expert to the politician." ${ }^{, 47}$ More recent positions on civil-military relations argue that Huntington's model is undermined by limited concordance between its theoretical assumptions and empirical evidence. After assessing the relationship between military professionalism and civilian intervention in the United States during the Cold War, Peter D. Feaver points out, for instance, that "Huntington's dichotomous model of subjective and objective control needs at least one additional category, assertive control, that contemplates the simultaneous existence of civilian meddling and military professionalism." 48

\footnotetext{
${ }^{45} \mathrm{Ibid}$.

${ }^{46}$ Peter D. Feaver, Armed Servants: Agency, Oversight, and Civil-Military Relations (Cambridge, MA: Harvard University Press, 2003), 7.

${ }^{47}$ Samuel P. Huntington, The Soldier and the State, 20.

${ }^{48}$ Peter D. Feaver, "The Civil-Military Problematique," 163.
} 
One of Huntington's a priori arguments is that "[t]he superior political wisdom of the statesman must be accepted as a fact," even in situations in which "the statesman decides upon war which the soldier knows can lead only to a national catastrophe."49 Yet he does not allow for what Clausewitz and other scholars see as the normal practice, in particular situations, of joint civil-military policy making and operational conduct. This presents analytical difficulties, since his model is based on the assumption that the military institutions and policies of a state are shaped by two forces: a functional imperative (that stems from the threats to a country's security) and a societal imperative (stemming from social forces, ideologies and institutions).

As both imperatives seem to be broad enough to have a significant impact on civilians and armed forces alike, it is hard to believe that military and civilian leaders, as well as the institutions they represent, manage to stay separated from each other in terms of their tasks and impact on security and defence matters. Huntington tends to disregard the societal imperative as a noticeable independent variable and focus instead on the functional imperative (i.e., external threats) as the most important determinant in shaping civilian control over the military.

Huntington nonetheless points out that "[m]ilitary institutions which reflect only societal values may be incapable of performing effectively their military function. On the other hand, it may be impossible to contain within society military institutions shaped purely by functional imperatives." ${ }^{50}$ The professional military establishment, Huntington thus

\footnotetext{
${ }^{49}$ Samuel P. Huntington, The Soldier and the State, 76.

${ }^{50}$ Ibid., 2.
} 
seems to suggest, has in fact a complex relationship with the contemporary state and its civilian leadership. Critics of Huntington's work find the idea of civil-military separation unconvincing: as James Burk points out, "[i]n an era still beset by weapons of mass destruction, there can be no clear distinction between the ends and means of war, between the policy decisions of political elites and the operational decisions of military elites." This thesis focuses specifically on the correlation between functional factors, which stem from threats to society, and civil-military relations.

\section{II.3.c. Morris Janowitz}

While often looking at the same empirical "facts" as Huntington, Morris Janowitz presented a different perspective on civilian control over the military. His book, titled The Professional Soldier, proposed a model of political oversight of the armed forces that would both enable the military establishment "[t]o perform its national security duties and provide it with a new rationale for civilian political control." ${ }^{32}$ Instead of Huntington's compartmentalized roles assigned to the statesman and the military commander, Janowitz's model postulates that the armed forces are a creation of the broader polity in which they exist; that the military establishment increasingly resembles police forces; and that - on an implicitly normative level - this institution should retain close links with the society. These "constabulary" forces (to use Janowitz's terminology) are not consigned to their own separated area of competence; on the contrary, they are

\footnotetext{
${ }^{51}$ James Burk, "Theories of Democratic Civil-Military Relations," 13.

${ }^{52}$ Morris Janowitz, The Professional Soldier: A Social and Political Portrait (Glencoe, IL: The Free Press, 1960), ix.
} 
deeply integrated with civilian authorities and the society at large, including in the realm of policy making.

It is precisely this situation, Janowitz argues, that accounts for the effectiveness of civilian control in Western contexts: the constabulary officer "is subject to civilian control, not only because of the 'rule of law' and tradition, but also because of selfimposed professional standards and meaningful integration with civilian values., 53 Janowitz's model of civil-military integration is based on an unwritten agreement: while civilian authorities permit the officer corps to develop their professional skills and to maintain their code of honour, the military leadership "[r]ecognizes that civilians appreciate and understand the tasks and responsibility of the constabulary force."

Similar to Clausewitz's work, there is an acknowledgement here that the lines of responsibility between civilians and the military are not clear-cut. Nor could they be, according to Janowitz: not only do the military and civilian leaders have overlapping responsibilities in many instances, but the armed forces cannot be politically neutral, as prescribed by Huntington. ${ }^{55}$ Even a military that is non-partisan in domestic politics "needs to be committed to the basic format of a democratic political system.,"56 According to the author of The Professional Soldier, the military establishment "[b]ecomes a constabulary force when it is continuously prepared to act, committed to the

\footnotetext{
${ }^{53}$ Ibid., 420.

${ }^{54}$ Ibid., 440.

${ }^{55}$ Part of the difference between the perspectives proposed by Samuel P. Huntington and Morris Janowitz may be explained by the fact that Huntington was, by profession, a political scientist, while Janowitz was a sociologist.

${ }^{56}$ Morris Janowitz, The Military in the Political Development of New Nations, 101-102.
} 
minimum use of force, and seek[ing] viable international relations rather than victory. The statement strikes the reader as possibly characterizing today's armed forces and their approach to military conflict even better than at the time of the book's writing.

Peter D. Feaver explains the constabulary concept as one under which "the distinctions between war and peace disappear and the military draws its inspiration from the image of the police officer than the warrior," although in the international, rather than domestic, realm. ${ }^{58}$ It is Janowitz's understanding that the standards and values underlying the constabulary forces' position is one of the key factors affecting the interaction between civilians and the military on security and defence matters. While agreeing with Janowitz's stance in general terms, this thesis approaches the above-mentioned factors as intermediate variables, being themselves shaped to a critical extent by the threat environment that a country faces.

Janowitz himself drew a correlation between the external threat environment and military roles, the former having a direct impact on patterns of civil-military relations - although he did not elaborate on this linkage to a significant extent. Peter D. Feaver points out that, according to Janowitz's model, "[civil-military] friction increases when the external threat dictates that the military should take on a constabulary role or when the civilian and military elites are not well integrated." 59 Especially in the post-9/11 threat environment, in which the armed forces seem to take on more constabulary roles and

\footnotetext{
${ }^{57}$ Janowitz, The Professional Soldier, 418.

${ }^{58}$ Peter D. Feaver, "The Civil-Military Problematique," 164.

${ }^{59}$ Peter D. Feaver, "Crisis as Shirking: An Agency Theory Explanation of the Souring of American CivilMilitary Relations," Armed Forces \& Society, vol. 24, no. 3 (Spring 1998), 408.
} 
there are frequent instances of disagreement between civilian and military leaders, friction may become a semi-permanent feature of today's civil-military relations.

\section{II.3.d. Samuel E. Finer}

Another powerful critique of Huntington's model of "objective" civilian control over the armed forces came from Samuel E. Finer, who argued in his book The Man on Horseback that maximizing military professionalism does not offer any plausible guarantees for better civil-military relations. Even in Western countries, i.e., in systems based on the principle of civilian supremacy, "the military's consciousness of themselves as a profession may lead them to see themselves as the servants of the state rather than of the government in power. They may contrast the national community as a continuous corporation with the temporary incumbents of office. ${ }^{.60}$ Looking at that phenomenon, whose most extreme manifestation is a military coup, Finer investigated not only the factors that could explain it, but also the reasons why the military does not become involved in partisan domestic politics more often.

Either because of "disposition" or "opportunity," the armed forces may be tempted to challenge their political masters' position. The military may be compelled to do so by an image of itself as an institution whose high moral prestige and strong expertise on defence matters position it well for such a move. Finer argued, against Huntington, that these tendencies could grow out of the armed forces' professionalism and relative

${ }^{60}$ S. E. Finer, The Man on Horseback: The Role of the Military in Politics (London: Pall Mall Press, 1971), 25. 
isolation from the broader society, which could lead to civil-military conflicts. Nonpartisan involvement of the armed forces in domestic politics ought not to be reprimanded, according to Finer - on the contrary: "[t]hey have both the right and the duty to attempt this. They are in no better, but certainly no worse a moral position than any departments of the civil administration which also have the right and duty to persuade the government to their point of view." $" 61$

Finer made the case for closer integration between the military establishment and the national community. "To inhibit such a desire [to intervene]," Finer added, "the military must also have absorbed the principle of the supremacy of the civil power." ${ }^{22}$ Finer's argument is similar to Janowitz's explanation of civilian control over armed forces in Western nations, although Finer focused more on the military, rather than the civilian principals; he thus somewhat overlooked the issue of political oversight of security and defence matters. While Janowitz's answer to the challenges of political control posed by civil-military fusion is "greater civilian oversight at many more levels of military affairs, ${ }^{, 63}$ Finer doesn't seem to offer one best prescription on this issue.

\footnotetext{
${ }^{61}$ Allan R. Millett, The American Political System and Civilian Control of the Military: A Historical Perspective (Columbus: Ohio State University Press, 1979), 137, cited in Kenneth W. Kemp and Charles Hudlin, "Civil Supremacy over the Military: Its Nature and Limits," Armed Forces \& Society, vol. 19, no. 1 (Fall 1992), 19.

${ }^{62}$ S. E. Finer, The Man on Horseback, 28.

${ }^{63}$ Peter D. Feaver, "The Civil-Military Problematique," 165.
} 


\section{II.3.e. Rebecca L. Schiff}

Among the more recent contributions to the civil-military relations literature, Rebecca $\mathrm{L}$. Schiff offered a notable alternative to the classical model, whose key proponent has been, for decades, Samuel P. Huntington. Schiff saw the need for a new civil-military relations model, which she called "theory of concordance," arguing that the physical and ideological separation between a state's civilian leadership and the military was historically and culturally bound to the West, especially to the American case. Her theory argues that "three partners - the military, the political elites and the citizenry - should aim for a cooperative relationship that may or may not involve separation but does not require it."64 However, critics of Schiff's work point out that even her theory of concordance has to acknowledge an important degree of separation between civilians and armed forces: indeed, "she treats the military as distinct from the political leadership as distinct from the citizenry - introduction of the latter into the theoretical mix representing the heart of concordance theory's contribution to civil-military relations theory."65

The ability of the three partners (the military, the political elites and the citizenry) to agree on several indicators (political decision-making, recruitment method, social composition of the officer corps and military style), which is facilitated or hindered by each country's historical and cultural experiences, is what explains, according to Schiff, the likelihood of domestic military intervention. It is the centrality Schiff places on

\footnotetext{
${ }^{64}$ Rebecca L. Schiff, "Civil-Military Relations Reconsidered: A Theory of Concordance," Armed Forces \& Society, vol. 22, no. 1 (Fall 1995), 7.

${ }^{65}$ Peter D. Feaver, "The Civil-Military Problematique," 168.
} 
culture, along with the introduction of the citizenry, in analyzing the interaction between civilians and armed forces that sets her theory apart from other models. Schiff takes into account the historical and cultural conditions that may encourage or discourage civilmilitary separation. This theory, which highlights specifically "dialogue, accommodation, and shared values or objectives among the military, the political elites and society," seems to be very much influenced by the Israeli experience of civil-military relations, with which Schiff is familiar.

A key aspect of Schiff's theory that seems to have been overlooked by many of her critics is that the theory of concordance, unlike the vast majority of other Western models of civil-military relations, "does not presume that civilian institutions must control the military. ${ }^{, 67}$ What seems in Schiff's view as the universal applicability of the theory of concordance could simply be closer compatibility of this model with non-Western environments. At the same time, employing the theory in studying Western civil-military relations while not presuming the necessity of civilian control, could be highly problematic. Furthermore, the theory of concordance seems to have the unexpected sideeffect of diluting the concept of "military intervention" in the civilian realm; as Richard S. Wells pointed out, "when the military is an equal partner in a social or political process of reaching agreement, then one might reasonably presume that what we think of as intervention is not necessary." ${ }^{.68}$ On this point, the extent to which the theory of concordance could usefully contribute to this thesis is rather limited, since the definition

\footnotetext{
${ }^{66}$ Rebecca L. Schiff, "Civil-Military Relations Reconsidered," 12.

${ }^{67}$ Rebecca L. Schiff, "Concordance Theory: A Response to Recent Criticism," Armed Forces \& Society, vol. 23, no. 2 (Winter 1996), 277.

${ }^{68}$ Richard S. Wells, "The Theory of Concordance in Civil/Military Relations: A Commentary," Armed Forces \& Society, vol. 23, no. 2 (Winter 1996), 272.
} 
of a Western model of civil-military relations used here assumes the existence of civilian control over armed forces.

\section{II.3.f. Douglas L. Bland}

Douglas L. Bland proposed a related model of civil-military relations, the "theory of shared responsibility," yet he went to great lengths to assure his readers that this theory was firmly based on the principle of civilian control over armed forces. "Although consensus making is a critical component of defence administration," Bland argued, "it does not absolve politicians from making decisions nor does it give the high command veto power over policy. Shared responsibility does not mean equal responsibility." ${ }^{\text {"69 }}$ His model approaches the interaction of civilians and the military as a partnership arrangement and tries to contribute to a field whose puzzles, Bland suggests, are obscured by its under-theorizing.

The essence of Bland's theory is that civilian control over armed forces is managed and maintained through regimes of shared responsibility between the two partners for oversight of the military: "specifically, civil authorities are responsible and accountable for some aspects of control and military leaders are responsible and accountable for others. Although some responsibilities for control may merge, they are not fused."70 The interaction of partners is regulated by sets of principles, norms, rules and decision-

\footnotetext{
${ }^{69}$ Douglas Bland, "Protecting the Military from Civilian Control: A Neglected Dimension of Civil-Military Relations," Democratic and Civil Control over Military Forces - Case Studies and Perspectives, no. 3 (1995), 112.

${ }^{70}$ Douglas L. Bland, “A Unified Theory of Civil-Military Relations," Armed Forces \& Society, vol. 26, no. 1 (Fall 1999), 9.
} 
making procedures, different from a national context to another. While "the sole legitimate source for the direction and actions of the military is derived from civilians outside the military/defence establishment," ${ }^{, 71}$ the theory of shared responsibility refutes Huntington's assumption of civil-military separation. Bland's model allows a significant degree of military input into policy-making processes, as well as occasional intervention by politicians in military planning.

Unlike Huntington, Bland argues that the model of "objective civilian control" does not correspond to empirical patterns of civil-military relations and "even if it were possible to construct [Huntington's] ideal system, it would not necessarily secure civilian control over the military and could hinder it in fact." ${ }^{.72}$ The theory of shared responsibility sees the military officer and its civilian counterpart as partners - while the former can be not only commander but also expert and advisor in policy making, the latter could assume the role of commander and advisor in specific military operations. "Even though there may be occasional friction," Harald von Riekhoff explains, "ultimately civilian and military leaders have shared interests and complementary roles in deciding and managing national defense." 73

Unlike Schiff, Bland builds his model along traditional lines, focusing on the interaction between civilian and military elites, with the exclusion of the citizenry - a framework that this thesis employs as well. "The unanswered questions," Bland admits, "are how and where the balance [between civilian and military leaders' responsibilities] is struck

\footnotetext{
${ }^{71}$ Ibid., 10.

72 Douglas Bland, "Protecting the Military," 113.

${ }^{73}$ Harald von Riekhoff, introduction, 9.
} 
and how it is managed over time. ${ }^{.74}$ Striking and managing that balance is even more difficult given the fact that patterns of civil-military relations are different in peacetime from wartime or times of crises - the author argues that profound changes take place in prolonged crises.

\section{II.3.g. Michael C. Desch}

The most elaborate study to date on the impact of threat environments on domestic civilmilitary relations has been conducted by Michael C. Desch. His book Civilian Control of the Military ${ }^{75}$ and other publications offer a structural theory of civil-military relations, inspired inter alia by Samuel Huntington's The Soldier and the State, Kenneth Waltz's Theory of International Politics" ${ }^{76}$ and Peter Gourevitch's article "The Second Image Reversed." 77 Based on the combination of location of threats (international/external or internal/domestic) and their intensity (high or low), his theory creates four distinct configurations of threats and, associated with them, different patterns of civil-military relations.

A predecessor of Desch's framework, Harold Lasswell's 1941 model, usually known as the "garrison state," is based on the idea of an increased role of the military in society in situations of heightened external threats. A world of garrison states would be, in Lasswell's conception, "a world in which the specialists on violence are the most

\footnotetext{
${ }_{75}^{74}$ Douglas L. Bland, "A Unified Theory of Civil-Military Relations," 12.

${ }^{75}$ Michael C. Desch, Civilian Control of the Military.

${ }^{76}$ Kenneth N. Waltz, Theory of International Politics (Reading, MA: Addison-Wesley, 1979).

${ }^{77}$ Peter Gourevitch, "The Second Image Reversed: The International Sources of Domestic Politics," International Organization, vol. 32, no. 4 (Autumn 1978), 881-911.
} 
powerful group in society. ${ }^{, 78}$ In a context in which the consequences of contemporary warfare may not discriminate between civilians and soldiers, Lasswell made a case for the possibility of unstoppable involvement of armed forces in the running of society at large. Also, Jay Stanley explains, "[a]s military technology continued to evolve, the garrison state would call for these specialists, that is, technologically sophisticated military personnel, to be in control of society. ${ }^{, 79}$ Unlike Harold Lasswell, ${ }^{80}$ Desch argues that in challenging international threat environments the military should be easier to control by civilian authorities.

Desch argues that threats, his independent variable, affect patterns of civil-military relations, having an impact on the civilian authorities, the armed forces and the society as a whole. Specifically, they have a significant impact on "the character of the civilian leadership, the structure of the military institution, the cohesiveness of state institutions, the method of civilian control, and the convergence or divergence of civilian and military ideas and cultures." ${ }^{81}$ His theory of civilian control of the military as a function of location and intensity of threats posits that the most desirable patterns of civil-military relations ("good") can be found in situations of low internal and high external threats; "fair" relations in situations of low internal and external threats; "poor" relations in situations of high internal and external threats; and "worst" civil-military relations in cases of high internal and low external threats.

\footnotetext{
${ }^{78}$ Jay Stanley, introduction to Essays on the Garrison State, ed. Jay Stanley (London: Transaction Publishers, 1997), 23.

${ }^{79}$ Ibid., 56.

${ }^{80}$ Harold Lasswell, "The Garrison State," American Journal of Sociology, vol. 46, no. 4 (January 1941), 455-468.

${ }^{81}$ Michael C. Desch, "Soldiers, States, and Structures: The End of the Cold War and Weakening U.S. Civilian Control," Armed Forces \& Society, vol. 24, no. 3 (Spring 1998), 392.
} 
Patterns of civilian control range from "good" to "worst" based on the extent to which civilian authorities prevail in policy disputes with their armed forces: "if the military does, there is a problem; if civilians do, there is not." ${ }^{\text {82 }}$ At its best, civil-military relations are based on Huntington's mechanisms of objective civilian control, which, in Desch's formulation, "involve granting the military substantial autonomy in the narrow military realm in return for complete political loyalty." ${ }^{, 83}$ The following matrix is proposed by Michael C. Desch for "civilian control of the military as a function of location and intensity of threats" ${ }^{84}$ :

\begin{tabular}{|r|r|r|}
\hline & $\begin{array}{l}\text { External threats: } \\
\text { High }\end{array}$ & $\begin{array}{l}\text { External threats: } \\
\text { Low }\end{array}$ \\
\hline $\begin{array}{r}\text { Internal threats: } \\
\text { High }\end{array}$ & $\begin{array}{r}\text { (Q3) } \\
\text { "Poor" }\end{array}$ & $\begin{array}{r}\text { (Q4) } \\
\text { "Worst" }\end{array}$ \\
\hline $\begin{array}{r}\text { Internal threats: } \\
\text { Low }\end{array}$ & $\begin{array}{r}\text { (Q1) } \\
\text { "Good" }\end{array}$ & $\begin{array}{c}\text { (Q2) } \\
\text { "Mixed" }\end{array}$ \\
\hline
\end{tabular}

Desch admits that his theory is of limited value when external and internal threats are similar: both low or both high - quadrants (2) and (3). Since Desch's structural theory is challenged by indeterminate threat environments, the theory could potentially illuminate

${ }^{82}$ Ibid., 391.

${ }^{83}$ Michael C. Desch, "Threat Environments and Military Missions," in Civil-Military Relations and Democracy, ed. Larry Diamond and Marc F. Plattner (Baltimore and London: The Johns Hopkins University Press, 1996), 14.

${ }^{84}$ Michael C. Desch, Civilian Control of the Military, 14. 
Western civil-military relations in situations of clear differentiation between internal and external threats only quadrants (1) and (4). Yet, more fundamentally, Desch's framework is built on the assumption of the existence of internal and/or external enemies, i.e., forces that can be identified as members of a particular polity or threatening it from outside. The matrix proposed by Michael C. Desch does not allow for any grey areas in analyzing and categorizing domestic and foreign security challenges. As will be discussed in the next chapter of this thesis, this rigid framework is largely inapplicable in a post-9/11 context. In the new threat environment, the most recognizable security menace is terrorism - the human agents using it as a strategy do not necessarily have a fixed postal code; frequently, they do not identify themselves with any particular country in the first place.

\section{II.3.h. Peter D. Feaver}

Firmly rejecting civil-military relations models such as the theory of concordance proposed by Rebecca L. Schiff - which are based on blurred lines of separation between civilians and armed forces - Peter D. Feaver argues that a theory in this field must assume the existence of distinct civilian and military spheres: "if the spheres are not at least analytically distinct, the theory is no longer about civil-military relations. ${ }^{985}$ Feaver also argues that any valuable analytical framework should be deductively derived at and, if focusing on civilian control over armed forces, it should identify the factors shaping the patterns of civilian oversight of the military: "it makes sense to develop a theory that encompasses the entire basket of control mechanisms and explains the factors that shape

\footnotetext{
${ }^{85}$ Peter D. Feaver, "The Civil-Military Problematique," 168.
} 
the ongoing process of civilian choices from among the basket. ${ }^{.86}$ The result is an analytical framework based on a radically different approach than the ones emphasized by the field.

In sharp contrast to Desch's structural theory of civil-military relations and even to classical work in the tradition of Huntington, Janowitz and Finer, Peter D. Feaver offers an agency theory, by approaching the interplay between state authorities and armed forces in terms of a game of strategic interaction. ${ }^{87}$ Feaver looks at the "microfoundational logic" of civil-military relations: the state authorities (i.e., principals) decide whether to monitor the armed forces (i.e., agents) intrusively (or not); the military decides whether to "work" or "shirk" (i.e., obey or ignore civilians' orders); and the principals decide whether to punish their agents (or not) when they shirk. Approaching civilmilitary relations from a game theory perspective, Feaver hopes to establish a model of civilian control over armed forces with better explanatory power than frameworks in the Huntington or Janowitz tradition. "Despite their prominence," Feaver argues, these frameworks do not "adequately explain the problem of civilian control and so [they] are uncertain guides for future study and policymaking. 988

Decisions on one side or the other are made based on several considerations: policy differences between states authorities and armed forces, the cost of monitoring and the likelihood of punishment. Feaver's most important hypothesis is simple: "conflict results when civilians have incentives to monitor intrusively and the military has incentives to

\footnotetext{
${ }^{86}$ Ibid., 167.

${ }^{87}$ Peter D. Feaver, "Crisis as Shirking," 407-434.

${ }^{88}$ Peter D. Feaver, "The Civil-Military Problematique," 150.
} 
shirk. ${ }^{.89}$ The extensive form of his game is slightly more complex, yielding several equilibria - "several pairs of civilian and military patterned behaviors that represent the rational responses each side would make given expectations of the other's behaviour. Yet, like a majority of scholars working in this field, Feaver is careful to emphasize the importance of firm civilian control over the military.

Feaver's framework and method present the potential of offering powerful results and illuminate many empirical puzzles in the area of civil-military relations; they seem to be of limited use, however, when approaching the more substantive question of the field: why would the military obey their principals, if they (as agents) have a monopoly over the use of legitimate violence in society? Feaver himself recognizes that it is, after all, the military's "voluntary and purposeful adherence to the principle of civilian control [that] ensures civilian control, ${ }^{, 91}$ which transcends the rather technical interaction between civilians and armed forces that Feaver's model is based upon. But Feaver's theory does try to overcome what he perceives to be a key weakness in classical frameworks: the reliance on the concept of military professionalism. This notion, at least in Huntington's conception, "defines away the very political problematique" of civil-military relations. ${ }^{92}$ The value of Feaver's model is in trying to redress this situation, by incorporating in a theory of civil-military relations both rational-interest and value-based factors (alas, the emphasis seems to be predominantly on the former).

\footnotetext{
${ }^{89}$ Peter D. Feaver, "Crisis as Shirking," 408.

${ }^{90}$ Ibid., 410.

${ }^{91}$ Peter D. Feaver, Guarding the Guardians: Civilian Control of Nuclear Weapons in the United States (Ithaca: Cornell University Press, 1992), 253.

92 Peter D. Feaver, “The Civil-Military Problematique," 169.
} 


\section{II.3.i. Eliot A. Cohen}

Another important voice in the chorus of criticisms of Huntington's notions of military professionalism and sharp division of labour between the responsibilities of civilians and armed forces belongs to Eliot A. Cohen. In his recent book titled Supreme Command, he rejects Huntington's notion of objective control on both normative and empirical grounds. Cohen investigates the interaction of civilian and military leaders in wartime and points out that "an examination of recent history - including even the relatively successful [first] Gulf War - suggests that the Huntingtonian model of desirable civilmilitary relations does not characterize conflict." ${ }^{.93}$ Cohen focuses in depth on the interplay between four war statesmen and their respective military leaders; the successful role of Abraham Lincoln, Georges Clemenceau, Winston Churchill and David BenGurion in the political and military affairs of their countries leads Cohen to conclude that civilian intervention in what is typically perceived as an area of military professionalism is ordinary and even desirable.

Contrary to the assumptions of the "normal" theory of civil-military relations, based inter alia on the idea of non-interference of civilians in matters deemed as inherently military (e.g., operational or tactical aspects of warfare), Cohen argues that "the great statesmen do just those improper things - and, what is more, it is because they do so that they

\footnotetext{
${ }^{93}$ Eliot A. Cohen, Supreme Command: Soldiers, Statesmen and Leadership in Wartime (New York: The Free Press, 2002), 229.
} 
succeed" militarily ${ }^{94}$ Cohen finds this approach to civil-military relations not only compelling, but also validated by historical experience - even Carl von Clausewitz observed, in his well-known dictum, that war is merely a continuation of politics by other means. "The Clausewitzian formula for civil-military relations," the author of Supreme Command points out, "has it that the statesman may legitimately interject himself in any aspect of war-making, although it is often imprudent for him to do so." ${ }^{, 95}$ Nonetheless, Cohen is quick to add that it is not only a misleading premise to assume the existence of an arbitrary line between civilian and military responsibilities, but also a dangerous practice, which could cause the very destruction of states.

The more recent wars (including the Cold War), Cohen seems to suggest, underline the obsolete character of military professionalism, as defined by Huntington. In scholarly terms, this aspect was noticed decades ago by Morris Janowitz in his book The Professional Soldier, as Cohen points out: "[a]s a result of the complex machinery of warfare, which has weakened the line between military and non-military organization, the military establishment has come more and more to display the characteristics typical of any large-scale organization." ${ }^{96}$ Critics of Cohen's book point out, however, that his selection of cases (Lincoln, Clemenceau, Churchill and Ben-Gurion) is biased, as he deliberately chose political leaders whose active involvement in military affairs did lead to success on battlefront. But Cohen's work is a refreshing addition to the undertheorized field of civil-military relations; by challenging the "normal" theory, it raises important questions for the interaction between civilians and armed forces in a context in

\footnotetext{
${ }^{94}$ Ibid., 5, emphasis in original.

${ }^{95}$ Ibid., 8.

${ }^{96}$ Janowitz, The Professional Soldier, 15.
} 
which it is difficult to identify many aspects of today's military conflicts that do not have significant political implications.

The principal theoretical framework for this thesis is, as noted earlier, Michael C. Desch's outline of the relationship between the overall threat environment and national patterns of civil-military relations. Thus, the thesis sheds light not only on practical developments in recent patterns of interaction between civilian and military leaders, but also on the broader issue of the linkage between security challenges and civil-military relations, as defined in theoretical debates. It is of both immediate practical relevance and broader theoretical significance, since this area of research has only been explored to a small extent in the post-Cold War period (and even less so in the post-9/11 context). 


\section{New Threat Environment, New Strategic Priorities}

\section{III.1. Introduction}

The third chapter of this thesis investigates the post-Cold War threat environment, specifically following the events of September 11, 2001. On the one hand, it analyzes the security context from a general perspective, with no particular reference to any national setting. After presenting a few terminological considerations, the following subsection addresses the impact of $9 / 11$ on the post-Cold War world order - which meant, according to the vast majority of observers, the dawn of a new era in international relations and in the way security and defence matters have since been tackled. The first section argues then that the security context has been altered by what was generally perceived to be a new breed of terrorism, which has become potentially more deadly and disruptive in possible combination with weapons of mass destruction and the facilitating support of failed or failing states.

On the other hand, the chapter analyzes the post-Cold War and particularly post-9/11 security situation by employing two case studies, Canada and Romania. A few introductory remarks set the stage for the more substantive discussion of each section, by offering a broad picture of the place of each country, taken individually, in the post-Cold 
War international security context. The following subsections then elaborate on recent perspectives on threats and the global milieu from a national point of view. This analysis is followed by an assessment of post-9/11 security concerns in Canada and Romania respectively, and by a discussion of new security priorities that indicate both changes in the way threats are perceived and the re-conceptualization of countries' involvement in the international arena.

The global security context triggered responses at both the domestic and the international level, but also a repositioning of countries vis-à-vis the world's sole superpower, the United States. A brief analysis of policy-related, strategic and institutional changes is used here only to the extent that they offer evidence for the existence of a qualitatively different post-9/11 threat environment and world order - an in-depth analysis of state responses will be offered in the next chapter, by looking specifically at a set of intermediate variables. However, before delving into the actual analysis of the post-9/11 threat environment (and its perception in countries such as Canada and Romania), a few terminological remarks are to be made.

The term terrorism is used in academic and non-academic literatures with a myriad of meanings; therefore, defining it in the context of this thesis is imperative. Many authors argue that its very use signals a normative stance on various social phenomena involving elements of violence - since "one's terrorist is another's freedom fighter," as the saying goes, the use of the term would mean placing the individual(s) or group(s) presented as such in a category seen a priori as evil. For the purposes of this thesis, a more technical 
definition of terrorism will be used, focusing on the methods and type of actors involved in terrorist activities. For, as Paul Wilkinson argues, "[t]o fall into the nominalist trap of claiming that terrorism does not exist but is merely a 'boo' word for 'freedom fighter' is simply to close one's eyes to whole ugly areas of historical and psychological reality. 997 A panel appointed to reform the United Nations (UN) adopted the same position in November 2004: the High-Level Panel on Threats, Challenges and Change urged the UN to send "an unequivocal message that terrorism is never an acceptable tactic, even for the most defensible of causes. ${ }^{998}$

The definitions of terrorism, terrorist group and international terrorism chosen here are the ones employed by the United States Department of State. According to these definitions, the term terrorism means "premeditated, politically motivated violence perpetrated against noncombatant targets by subnational groups or clandestine agents;" the term terrorist group means "any group practicing, or which has significant subgroups which practice, international terrorism;" the term international terrorism means "terrorism involving citizens or the territory of more than one country." main implications of these definitions is that only subnational groups or clandestine agents can practice terrorism; governments cannot. Thus, violence employed by a country's state structures cannot be defined as terrorism, no matter the methods used. At the same time, nor can violence perpetrated against a country's armed forces be seen as terrorism, as the targets of terrorism have to be noncombatant (that is, civilians).

\footnotetext{
${ }^{97}$ Paul Wilkinson, Terrorism and the Liberal State (New York: New York University Press, 1986), 57.

${ }^{98}$ Anton La Guardia, "UN told to take tougher stand against terror," The Daily Telegraph, November 30, 2004.

${ }_{99}$ United States Department of State, Country Reports on Terrorism 2004 (Washington, DC: US Department of State, 2005), 1.
} 
Also, as W. Raymond Duncan points out, "[i]t is important to note that terrorists should not be confused with 'soldiers,' even if the terrorists say they are waging 'a war.' The main reason is that, in most cases, terrorists violate the rules that govern armed conflict, by deliberately targeting civilians and taking hostages."100 Given all the elements mentioned above, individuals perpetrating terrorism or terrorist groups cannot be seen as legitimate actors to enter the interaction between political leaders and armed forces, according to a traditional conceptualization of the field of civil-military relations. Terrorism can indeed have a significant impact on civil-military relations (as this thesis argues), yet terrorists or terrorist groups are approached in this context as a threat (independent variable) rather than entities that can be brought into the area of mainstream political interaction.

The difficulty of even attempting to bring terrorists or terrorist groups into mainstream political life is related to the means they employ in perpetrating their acts: "the systematic use of murder and destruction, and the threat of murder and destruction, to terrorize individuals, groups, communities or governments into conceding to the terrorists' political aims," a type of violence characterized by its "indiscriminateness, inhumanity, arbitrariness and barbarity."101 Many scholars caution, however, against including all forms of violence employed by subnational groups or clandestine agents under the umbrella of terrorism. This should be differentiated, they argue, from "other low-level forms of political violence by nonstate actors such as guerrilla warfare, ethnic or

\footnotetext{
${ }^{100}$ W. Raymond Duncan et al., World Politics in the 21st Century (New York: Longman, 2002), 274.

${ }^{101}$ Paul Wilkinson, Terrorism and the Liberal State, 56.
} 
nationalistic separatist violence, and violent efforts to overthrow governments, among others." 102 State-sponsored terrorism, involving the use of subnational groups or clandestine agents by governments, should also be differentiated from governments' legitimate use of their own armed forces, even in controversial military operations.

The term weapons of mass destruction (WMD) refers to nuclear, biological, chemical and possibly (in the future) other types of weapons used by governments and non-state actors "for the purpose of inflicting massive damage, including the killing of large numbers of civilians. The term consolidates nuclear, biological, and chemical weapons into one category because, despite differences in their effects and use, they share enormous lethality and symbolism."103

State failure could be defined in technical terms as "a range of severe political conflicts and regime crises" that include "revolutionary wars, ethnic wars, adverse regime changes, and genocides and politicides." 104 A broader approach would focus, nonetheless, on the (in)ability of states to provide basic political goods to their citizens, chiefly security. Robert Rotberg of the Program on Intrastate Conflict and Conflict Resolution at Harvard University uses this latter definition, but he makes a distinction between state failure,

\footnotetext{
${ }^{102}$ Martha Crenshaw and Maryann Cusimano Love, "Networked Terror," in Beyond Sovereignty: Issues for a Global Agenda, ed. Maryann K. Cusimano (Belmont, CA: Thomson Wadsworth, 2003), 124-125.

${ }^{103}$ Patrick Clawson (ed.), Strategic Assessment 1996: Elements of U.S. Power (Washington, DC: Institute for National Strategic Studies, 1996), 201.

104 Jack A. Goldstone et al., Internal Wars and Failures of Governance: 1955-2002

http://www.cidcm.umd.edu/inscr/stfail/index.htm, May 18, 2004 (accessed December 28, 2005).
} 
state collapse, state implosion and state disaster, based on a taxonomy that includes strong, weak, failed and collapsed states. ${ }^{105}$

These definitions will help focus the discussion of these factors in the context of this thesis and provide better integration of this study into the larger literature on security and defence matters in the post-Cold War and the post-9/11 era. The following section will offer a brief picture of the security "realities" of the 2001-2006 period and will elaborate on the main threat-related concerns of Western governments. The section serves to demonstrate the changing nature of the international security environment following the events of September 11, 2001; remaining sections of this chapter will offer an analysis of the threat environment and related responses in two national contexts (Canada and Romania).

\section{III.2. General Considerations}

\section{III.2.a. Introductory remarks}

The international threat environment has changed dramatically since the end of the Cold War. Relatively predictable patterns of the standoff involving the Soviet Union and the United States have been replaced by a myriad of problems ranging from minor ethnic rivalries to failed and failing states to environmental disasters. One of these problems, which seemed relatively minor in the first decade following the end of the Cold War,

\footnotetext{
${ }^{105}$ Robert I. Rotberg, "The Failure and Collapse of Nation-States: Breakdown, Prevention, and Repair," in When States Fail: Causes and Consequences, ed. Robert I. Rotberg (Princeton: Princeton University Press, 2003), 1-45.
} 
international terrorism, has risen to the forefront of public concern, at least in the West. In the aftermath of the terrorist attacks upon the United States on September 11, 2001, global terrorism has been perceived as one of the most important international issues threatening the security and stability of countries around the world.

Since it was the USA, today's only military superpower, that was hit in the most dramatic way by terrorists, a US-led "war on terror" was initiated immediately after the terrorist strikes. ${ }^{106}$ Under American leadership, governments have recognized international terrorism as a main, if not the most important, global threat to the stability of today's world. As Canadian Deputy Minister of Defence Ward Elcock pointed out, the new terrorism is more complex, sophisticated, widespread and unpredictable than ever before; especially in its religious and messianic forms, terrorism can be extremely deadly, even more so when combined with weapons of mass destruction. "If the world is a global village, terrorism is in every neighbourhood," Ward Elcock argued. ${ }^{107}$ Other scholars have pointed out as well that all Western nations have a stake in the new fight against terrorism. As historian J. L. Granatstein argued, the new threats affect all Western countries: "the Islamist war is being waged against the West, against democracy, and against secularism, not only against the United States. It is the defining issue of the present era, the struggle of a global medieval theocracy against modernity." 108 Countries such as Canada and Romania have proven clearly - in blood and treasure - their

\footnotetext{
${ }^{106}$ The phrase "war on terror" was quietly dropped from official discourse, in 2006-2007, by the United States and its key allies.

${ }^{107}$ Ward Elcock, "The Future Threat Environment," keynote address delivered to the Third War Studies Symposium Global Insurgency, Terrorism and Special Operations in the $21^{\text {st }}$ Century, organized by the Royal Military College of Canada and the Joint Special Operations University (USA), Kingston, ON, October 20, 2004.

${ }^{108}$ J. L. Granatstein, Whose War Is It? How Canada Can Survive the Post-9/11 World (Toronto: Harper Collins Publishers Ltd., 2007), 195.
} 
commitment to addressing the new security challenges and to supporting the United States in this effort.

Two other crucial issues related to international terrorism are the proliferation of weapons of mass destruction and failed and failing states - the latter could potentially be used by terrorist groups as bases to launch attacks throughout the world. This new threat-related agenda represented a clear departure from previous concerns over conflicts between states and between ideologically-divided blocks of countries. The dangers presented by terrorist attacks, such as those being perpetrated by al-Qaeda, are of a qualitatively different nature than the threats characterizing the international system prior to the end of the Cold War.

The nature of these new threats (among others, attacks by non-uniformed forces, striking by surprise) requires continuous monitoring and emergency preparedness on the part of state organizations, as well as military engagement against terrorist and insurgent groups; this presents the potential of putting significant pressure on defence and security forces. It also requires changes in the structures and policies of these organizations. On the other hand, after more than a decade of uncertainty, states and security and defence organizations throughout the Western world have identified threats they can generally agree upon (critics see this set of threats as just the lowest common denominator): international terrorism, the proliferation of weapons of mass destruction and failed and failing states. The new threats are deemed to be even more deadly when combined - such as terrorist incidents involving weapons of mass destruction. 
Not only states, but international organizations as well, such as the North Atlantic Treaty Organization, responded in a forceful manner to the challenges posed by global terrorism. NATO member states and candidate countries acknowledged the changed nature of the international threat environment and reacted swiftly to its requirements. NATO invoked, for the first time in its history, Article 5 of the North Atlantic Treaty of 1949 (its mutual defence clause) immediately following the terrorist attacks against the United States and NATO members initiated changes in their national security and defence establishments, while significantly increasing funding for homeland defence initiatives and military missions abroad. Both Canada and Romania, as NATO allies, ${ }^{109}$ were at the forefront of the newly discovered "war on terror," deploying troops to Afghanistan from the early moments of the US-led multinational military operations against that country's Taliban regime and associated al-Qaeda groups, as well as initiating and implementing consolidated homeland defence initiatives.

III.2.b. The impact of $9 / 11$ on the post-Cold War world order

With the end of the Cold War, a new era began, one in which the conceptualization of international dangers, in both scholarly and non-academic quarters, proved to be a difficult process, with many contenders for the position of top global threats. From international terrorism and weapons of mass destruction to organized crime and human security to environmental degradation and new pandemics, Western academics and

\footnotetext{
${ }^{109}$ In 2002, Romania was a NATO candidate country, yet it acted as a de facto member state; it would become a member of the North Atlantic Treaty Organization in 2004.
} 
practitioners considered a wide range of challenges as potentially undermining the world's security and stability. Yet no one particular threat rose to the forefront of states' concerns prior to $9 / 11$ as terrorism did in the aftermath of that fateful day.

"We've never had a good name for it, and now it's over. The post-cold war era - let us call it that for want of any better term - began with the collapse of one structure, the Berlin Wall [...], and ended with the collapse of another, the World Trade Center's twin towers," John Lewis Gaddis argues in a collection of essays on the impact of $9 / 11$ on the United States and the world. ${ }^{110}$ Not only governments and international organizations, but nongovernmental organizations (NGOs), substate groups and individuals as well, have generally been able to perceive qualitative changes in terms of empirical differences in the organization of world affairs and analytical approaches to global dynamics.

As Gaddis puts it, "[n]o one, apart from the few people who plotted and carried out these events, could have anticipated that they were going to happen. But from the moment they did happen, everyone acknowledged that everything had changed."111 Terrorism in particular represents a new and worrying threat: not being able to confront states' armed forces directly, given limited military means at their disposal, terrorist groups target civilians, knowing that governments will be affected via citizens' discontent. Terrorism thus tends to become a more formidable challenge, affecting all levels of society; the very fact that any neighbourhood can potentially become a deadly battlefield and that non-

\footnotetext{
${ }^{110}$ John Lewis Gaddis, "And Now This: Lessons from the Old Era for the New One," in The Age of Terror: America and the World after September 11, ed. Nayan Chanda and Strobe Talbott (New York: Basic Books, 2001), 3.

${ }^{111}$ Ibid.
} 
combatants have no different status from uniformed personnel in the eyes of their attackers makes this threat difficult to counter.

In recent years, closely associated to terrorism as serious security threats are the proliferation of WMD and failed and failing states. United Nations Secretary-General Kofi Annan explained in 2005 why a major terrorist attack with WMD against a Western country can send shockwaves around the world: "[i]f New York or London or Paris or Berlin were hit by a nuclear terrorist attack, it might not only kill hundreds of thousand in an instant," he said. "It could also devastate the global economy, thereby plunging millions into poverty in developing nations." 112 While weapons of mass destruction can dramatically increase the lethality of terrorist incidents, failed and failing states are a threat to international security given the possibility of their becoming safe havens for terrorist organizations; these countries can also become entangled themselves in regional conflicts, with their citizens joining local or global radical movements.

State failure is, however, a difficult concept to define and operationalize, and - moreover - is an empirical phenomenon that is not universally recognized as contributing to a significant increase in levels of threats such as international terrorism. Along with other scholars, David Carment approaches state failure as an increasing concern for the security of nations in the new strategic environment. State failures, Carment argues, "serve as the potential breeding ground for extremist groups." ${ }^{\text {113 }}$ Robert Rotberg and other experts

\footnotetext{
${ }^{112}$ Paul Ames, "UN chief warns of global terror threat," The Ottawa Citizen, February 14, 2005.

${ }^{113}$ David Carment, "Effective Defence Policy for Responding to Failed and Failing States," Canadian Defence \& Foreign Affairs Institute's Research Paper Series,
} 
disagree: there is no clear correlation, they argue, between state failure and threats such as international terrorism. ${ }^{114}$ Disagreements over the contribution of state failure to a heightened level of security threats to established polities placed this variable on a lower level in the countries' hierarchy of security threats than terrorism and WMD proliferation.

All these issues had already been debated and tentative responses to them had already been devised prior to 9/11; what the attacks of September 11, 2001, upon the United States did was to act as a catalyst for states' responses to the international security environment and to reconfigure the hierarchy of global threats, placing terrorism at the top of Western countries' concerns. There were many factors that gave the terrorist incidents of $9 / 11$ the iconic status they now have, as the landmark of a new era in international affairs: the fact that citizens of dozens of countries were killed in the 9/11 attacks, that many more US citizens were slaughtered that day than in all terrorist incidents of previous decades combined, that more American citizens lost their lives than US troops at Pearl Harbor or that the edifices targeted were at the core of American life at multiple levels. At the same time, according to a number of scholars, "[t]his new enemy was different. Osama bin Laden's organization, al Qaeda [which claimed responsibility for the attacks], flew no flag - it was the ultimate NGO - and his warriors seemed inspired rather than deterred by the prospect of their own fiery deaths."115

http://www.carleton.ca/cifp/docs/EffectiveDefencePolicyFailedStates.pdf, June 2005 (accessed July 2 , 2006), 5.

${ }^{114}$ Robert Rotberg, lecture on "Failed States in a Time of Terror," Carleton University, Ottawa, October 7, 2005.

${ }^{115}$ Nayan Chanda and Strobe Talbott, introduction to The Age of Terror, xi. 
Among other factors that made these attacks unprecedented were the innovative use of aircraft (high-tech, yet common objects) as weapons of mass destruction, the disregard for human life (the victims' and the terrorists' own lives) and even the determination to kill as many people and to destroy as much physical infrastructure as possible. As John Lewis Gaddis underlined, "[w]e confront, therefore, not only a new category of easily available weaponry, but a combination of skill and will in using it. The attack's costeffectiveness was equally striking." 116 Students of terrorism abandoned suddenly the notion that politically motivated violence is unlikely to be associated with gratuitous murders, since that would undermine the goals of the groups perpetrating it. The traditional idea in this area of study according to which "terrorists want a lot of people watching and a lot of people listening, not a lot of people dead" proved to be a grave error. "After the events of September 11, 2001, no one doubts that terrorists might be interested in killing a lot of people.",117

NATO Spokesman Jamie Shea pointed out in 2004 that the Atlantic Alliance's post-9/11 process of change, including NATO's subsequent intervention in Afghanistan (outside its traditional perimeter), can be explained by several key developments related to international terrorism. While terrorism is by no means a new political phenomenon, the global reach of this new type of violence experienced on $9 / 11$ "is something that was never known before in the long convulted history of terrorism;" the new terrorism showed a high level of sophistication on the part of its masterminds and their followers, as well as a very extended network of terrorist cells spread throughout the world (the

\footnotetext{
116 John Lewis Gaddis, "And Now This," 9.

${ }^{117}$ Scott D. Sagan, "Sagan Responds to Waltz," in The Spread of Nuclear Weapons: A Debate Renewed, ed. Scott D. Sagan and Kenneth N. Waltz (New York: W. W. Norton \& Company, 2003), 159.
} 
number of al-Qaeda operatives was thought to be in the tens of thousands), and "that too is something which is wholly new;" in addition to these elements, the vulnerability of our interdependent societies makes the impact of a terrorist attack "potentially global," with "repercussion on the economy, on our safety, on our ability to move around."118

Thus, one of the reasons why terrorism has risen to a top place among key threats to international security in recent decades (and, particularly, after 9/11) is the reality of terrorist incidents becoming increasingly deadly and ever more disrupting to contemporary societies. Associated with weapons of mass destruction, terrorism presents the potential of doing great harm to countries at multiple levels, on both material and psychological grounds. It is this mix of WMD and terrorism, alongside failed and failing states, that threatens the security of countries around the world and has contributed to the emergence of a qualitatively new international security environment since the end of the Cold War. At the same time, as Gen. Rick Hillier, Canada's Chief of the Defence Staff, pointed out, "[a] series of bombs can terrorize a city even when these bombers do not threaten fundamental security. Perception of threat can be as important as the threat itself." 119 In the same vein, Michael Barkun pointed out that the imagery of the 9/11 attacks was "apocalyptic, for it seemed to manifest world-destroying power;" the perception of such events, he argued, "is more powerful than any objective damage assessment. Indeed, as a practical matter, in this case as in other crisis situations,

\footnotetext{
${ }^{118}$ Jamie Shea, "The Impact of September $11^{\text {th }}$ on the Alliance," http://www.nato.int/docu/speech/2004/s040112a.htm, January 12, 2004 (accessed August 15, 2005). $\overline{119}$ Janice Gross Stein and Eugene Lang, The Unexpected War: Canada in Afghanistan (Toronto: Viking Canada, 2007), 212.
} 
perception is reality." ${ }^{\prime 20}$ Both of these positions also relate to the idea, frequently encountered in academic studies, that threats become "real" by being simply defined as such by governments and the broader society.

What seems to have changed with $9 / 11$ is not only the emergence of new means and ways of delivering violence, but also the widespread perception of being dragged into, and contributing to assemble, a new international security environment. While the direction of change has been set by the United States, countries and international organizations around the world followed shortly on the US footsteps, acknowledging the new nature of international security after 9/11. Additional terrorist incidents in the West (e.g., in Madrid, Spain, in 2004; in London, England, in 2005; etc.) seemed to confirm that 9/11 was not an isolated incident, but rather a typical example of the potential for destruction and disruption in the new threat environment. As Ben Lombardi of Canada's Department of National Defence pointed out, "[t]he problems which the world now faces are not new, and many are and will remain as intractable as ever, but the approaches adopted, the issues that will be addressed, and those that will remain at the periphery, are all shaped, to some degree, by the terrible events of 9/11."121 The following subsection will investigate the impact of this new set of security challenges on the post-9/11 era.

\footnotetext{
${ }^{120}$ Michael Barkun, "Defending against the apocalypse: The limits of homeland security," Policy Options, September 2002, 27-30.

${ }^{121}$ Ben Lombardi, "The International Security Environment," in Strategic Assessment 2003, ed. S. E. Speed (Ottawa: Department of National Defence, 2003), 15.
} 
III.2.c. A new breed of terrorism

US Secretary of State Madeleine Albright had said, years before 9/11, that the war against international terrorism was "the war of the future;" many other Western policy makers and observers had emphasized as well the attention that should be given to this threat. The attacks of September 11, 2001, only reinforced, although in an extremely destructive manner, this point made repeatedly during the post-Cold War period. With following attacks on Western countries, attributed as well to radical Islamic (or jihadist) groups, the concern is that the West must brace itself for a long confrontation with a dangerous enemy. Some experts believe, for example, that "al-Qaeda is mutating into a global insurgency, a possible prototype for other $21^{\text {st }}$-century movements, technologically astute, almost leaderless. And the way out is far from clear." ${ }^{\text {,122 }}$ Islamic extremism in general is seen as posing the most significant challenge to the community of liberal democratic countries, given the deep commitment of its followers to their radical causes and its disregard for alternative values or even human life.

The effectiveness of these groups in achieving material destruction, but mainly in terrorizing people and disrupting normal life is remarkably high. In general, as Joshua S. Goldstein points out, "the purpose of terrorism is to demoralize a civilian population in order to use its discontent as leverage on national governments or other parties to conflict. Related to this is the aim of creating drama to gain media attention for a

\footnotetext{
${ }^{122}$ Charles Hanley, “This war will be 'endless,' terrorism experts say,” Ottawa Citizen, July 10, 2005.
} 
cause." $^{\prime 123}$ The effectiveness of terrorists' actions is significantly increased by their potential use of weapons of mass destruction; the randomness of selecting their targets; the secrecy surrounding their activity and the non-hierarchical, networked structure of today's contemporary terrorist organizations; the easy accessibility of terrorists to new weapons and modern technology, to valuable information on means of destruction and effective methods of violence, and to the actual location of their planned attacks; the uncertain responses of governments to these new challenges; and the slippery nature of their ideologies. In relation to this latter aspect, Walid Phares in his book The War of Ideas: Jihadism against Democracy, argues that the most important battle in the war against terrorism takes place "in the hearts and minds of the world's population" and that the conflict opposes radical Islamic (jihadist) groups and Western states. ${ }^{124}$

Stephen Sloan points out that "[p]redictive capabilities are challenged by the fact that there is a whole range of potential new terrorist weapons and associated scenarios for destruction that create major problems for those responsible for identifying a new generation of terrorist threats."125 Major governments and international security organizations have attempted to address these concerns, yet their capacity to counter every possible scenario at any time in every possible location, at home and abroad, is obviously limited. The difficulty faced by the authorities is also underscored by what the National Commission on Terrorist Attacks Upon the United States (also known as the

\footnotetext{
${ }^{123}$ Joshua S. Goldstein, International Relations (New York: Pearson Longman, 2004$), 147$.

${ }^{124}$ Walid Phares, introduction to The War of Ideas: Jihadism against Democracy (New York: Palgrave Macmillan, 2007).

${ }^{125}$ Stephen Sloan, "Terrorism: How Vulnerable is the United States?," in Terrorism: National Security Policy and the Home Front, ed. Stephen C. Pelletiere (Carlisle Barracks, PA: Strategic Studies Institute, 1995), 61.
} 
9/11 Commission) identified in its final report as a "failure of imagination" on the part of the US intelligence services in grasping the magnitude of the terrorist threat. ${ }^{126}$ As the saying goes, military commanders, but also policy makers, still tend to fight yesterday's war.

It is in this atmosphere of official and public discourse focusing on the issue of "when, not if" new attacks will happen that the perception of threat associated with terrorism surpasses dramatically the awareness of risks in other areas of social life. Yet perception is often more important than "reality" in the globalized world in which markets may shift erratically with every significant development in the international arena, in which border closings due to security concerns may cause widespread economic depression and governments are under increasing pressure to protect their own citizens from external dangers. ${ }^{127}$ The result, Michael Barkun points out, "is a disturbing paradox: the overwhelming magnitude of the perceived danger $[\ldots]$ appears to mandate an immediate and radical response. Yet even the most dramatic mobilization of capacities cannot

\footnotetext{
${ }^{126}$ National Commission on Terrorist Attacks Upon the United States, 9/11 Commission Report, http://govinfo.library.unt.edu/911/report/index.htm, 2004 (accessed February 12, 2005).

${ }_{127}$ The fact remains that the number of significant terrorist incidents (according to most analysts, using different methodologies) has been on the rise following the end of the Cold War. One study indicates that the number of attacks increased from 124 to 175 during the 2001-2003 period; the same study shows that in the late 1990s and early this decade "terrorists tend to come from non-democratic countries, both rich and poor, and generally target nationals from rich, democratic countries" (Alan B. Krueger and David D. Laitin, "'Misunderestimating Terrorism': The State Department's Big Mistake," Foreign Affairs, vol. 83, no. 5 (September/October 2004), 12). The number of terrorist groups themselves seems to have expanded as well, with many still underground, thus not included in official reports. As of October 2001, the US Department of State had designated 28 groups as "foreign terrorist organizations" (FTO); as of April 2005, it identified 40 FTO and 40 other terrorist groups had been added to the list based on information from other reports (United States Department of State, "State Department Identifies 40 Foreign Terrorist Organizations," http://usinfo.state.gov/is/Archive/2005/Apr/27-320736.html, April 27, 2005 (accessed September 8, 2005)).
} 
produce the total security most people desire." ${ }^{\prime 28}$ This is possibly the best arrangement for highly successful terrorist attacks against Western nations.

"We're easy prey," Thomas Homer-Dixon argues, "because of two key trends: First, the growing technological capacity of small groups and individuals to destroy things and people; and, second, the increasing vulnerability of our economic and technological systems to carefully aimed attacks. ${ }^{129} \mathrm{He}$, along with many other students of terrorism, is equally concerned about the impact of WMD and "weapons of mass disruption" (the latter can be a mere terrorist scare) on our social existence.

In jujitsu style, terrorists turn the strengths of open society against itself; among other things, they use Western wealth and knowledge to develop the capacity to fight liberal democracies: “[y]ear after year it becomes easier for small bands of fanatics to perpetrate mass destruction because the means of destruction get cheaper and more readily available."130 Biological, chemical and nuclear weapons in the hands of terrorist groups (and rogue states) thus become the greatest danger to the security of Western nations. Experts point out that terrorist leaders such as Osama bin Laden have expressed repeatedly their desire to fight Western countries and have presented their efforts to acquire WMD (even to carry out a "Hiroshima") as a "religious duty."

\footnotetext{
${ }^{128}$ Michael Barkun, "Defending against the apocalypse: The limits of homeland security," 30.

${ }^{129}$ Thomas Homer-Dixon, "The Rise of Complex Terrorism," Foreign Policy, issue 128 (January/February 2002), 52.

${ }^{130}$ Niall Fergusson, "2011," The New York Times Magazine, December 2, 2001, 78.
} 
Many experts argue that, considering the destructiveness of WMD and the broader consequences of their use for international relations, "mitigating such threats should be an overriding security priority today, just as heading off a nuclear attack was an overriding priority during the Cold War." ${ }^{, 131}$ US authorities announced in October 2005 that "at least 10 serious al-Qaeda terrorist plans [had] been detected and disrupted by the US and its allies" following the events of $9 / 11$ (three of them against the USA); ${ }^{132}$ British police said in December 2004 that they "prevented terrorists from launching an attack in London on the scale of the Madrid train bombings" (adding that an attack on the capital remained "inevitable" - they would be proved right half a year later); ${ }^{133}$ Australian police outlined, in November 2005, a plot to bomb the country's only nuclear reactor; and both Canadian and Romanian authorities announced in the summer of 2006 that terrorist attacks against some of their most important cities were foiled and the suspects arrested.

The difficulty with terrorists, rather than states, planning violent actions arises from factors such as the virtual impenetrability of terrorist groups, the high level of intricacy of their networks, the feeble effectiveness of deterrence as a counterterrorism strategy and the weak capacity of governments in predicting terrorists' apparently erratic moves. Moreover, as Martha Crenshaw and Maryann Cusimano argue, "[b]ecause terrorist groups are increasingly networked globally, with training, recruitment, financing, and operations carried out in several countries, increased deaths of one country's citizens may

\footnotetext{
${ }^{131}$ William J. Perry, "Preparing for the Next Attack," Foreign Affairs, vol. 80, no. 6 (November/December 2001), 36,

132 ***, "10 terrorist plots detected: Bush," CBC News, October 6, 2005.

133 ***, " 'Stopped a Madrid,' British police say," The Globe and Mail, December 9, 2004.
} 
not reduce sympathy, support, and recruitment for the group in other countries." ${ }^{, 134}$ This aspect has become much clearer with the attacks of September 11, 2001, when the terrorists involved spared no effort to take as many human lives as possible, the death toll of $9 / 11$ nearing 3,000 .

While international agreements such as the Biological and Toxin Weapons Convention (1972) or the Nuclear Non-Proliferation Treaty (1968) may regulate somewhat state behaviour in the area of WMD, they are of limited (if any) significance in relation to the potential proliferation of weapons of mass destruction among terrorist groups, the latter not abiding to conventions signed by countries and organizations they resent.

\section{III.2.c.i. Nuclear terrorism}

The issue of nuclear terrorism has been widely debated following the end of the Cold War and experts are divided over the likelihood of actual terrorist incidents involving nuclear weapons happening. They point to the relatively complex technology involved in producing nuclear weapons and to the existence of weapons or devices based on the use of two distinct types of fissile material, plutonium and highly enriched uranium, particularly the former being difficult to produce with terrorist groups' supposedly unsophisticated means at their disposal. But recent studies on nuclear terrorism present it as a multifaceted, rather than unitary phenomenon, involving different kinds of threats: that terrorists "will disperse highly radioactive material by conventional explosives (i.e., 'dirty bombs') or other means, that they will attack or sabotage nuclear power

${ }^{134}$ Martha Crenshaw and Maryann Cusimano Love, "Networked Terror," 127. 
installations, that they will seize intact nuclear weapons, and that they will steal or buy fissile material for the purpose of building a nuclear bomb."135

While weapons-grade nuclear material that terrorists could use to assemble improvised weapons or radiological dispersal devices may be obtained from several sources, such as poorly-guarder former Soviet nuclear enterprises, governments' appropriate responses to this threat are far from clear. Deterrence, which was used by the West as an effective strategy during the Cold War against rival powers (chiefly among them, the Soviet Union), does not work in the fight against international terrorism. Some of the groups using terrorism as a strategy in advancing their political goals actually embrace the idea of dying for their cause, which rules out deterrence as an effective countermeasure.

Most of these groups are part of multinational networks, which makes it impossible to pinpoint their headquarters or other physical infrastructure that governments could strike using nuclear or conventional capabilities. Improvised weapons or radiological dispersal devices could be delivered to the country targeted by conventional means of transportation (car, boat, etc.) and detonated on site, so that the attack could be significantly more difficult to attribute to a particular group or country. Moreover, many terrorists have connections within the country that is the target of their attacks and it is highly unlikely that governments will engage in nuclear strikes on their own territory. ${ }^{136}$

\footnotetext{
${ }^{135}$ William C. Potter et al., "The Four Faces of Nuclear Terror," Foreign Affairs, vol. 83, no. 3 (May/June 2004), 130-131.

${ }^{136}$ Deterrence is not effective in fighting international terrorism, for the very assumptions underlying the interaction between the actors involved in the conflict have changed. As Victor D. Cha explains, deterrence worked during the Cold War because it was based on a set of clear axioms: "[f]irst, the target of the strategy was another nation-state. Second, this deterred state was assumed to have a degree of centralization in the decision-making process over nuclear weapons use. Third, and most important, the opponent
} 
While governments are yet to agree on a best strategy to address these new challenges, according to most sources nuclear smuggling seems to be on the rise and terrorist groups seem to be ever more determined to use weapons of mass destruction in incidents that could be of catastrophic proportions. International Atomic Energy Agency (IAEA) reports indicated not only that cases of nuclear smuggling were on the rise, but also that they involved larger numbers of participants and higher quantities of weapons-grade nuclear material. ${ }^{137}$ As the Nuclear Threat Initiative (NTI), a Washington, D.C.-based nongovernmental organization, emphasized repeatedly, highly enriched uranium can potentially be obtained by terrorist groups from hundreds of research reactors and other facilities in dozens of countries - "some of [them] secured by nothing more than an unpaid guard and a chain link fence. ${ }^{.138}$

Legal instruments on preventing international terrorism were still being worked upon during the period covered by this study, yet it is obvious that governments around the world, individually and collectively, encountered significant difficulties in devising effective responses to this growing challenge. In September 2005, world leaders began signing a new Convention for the Supression of Acts of Nuclear Terrorism, which would criminalize not only the destruction of nuclear facilities, but also the possession of radioactive material or weapons with the intention of using them in terrorist attacks, as

possessed both counterforce and countervalue targets that would be the object of a second strike" (Victor D. Cha, "Globalization and the Study of International Security," Journal of Peace Research, vol. 37, no. 3 (2000), 400).

${ }^{137}$ Rensselaer W. Lee and James L. Ford, "Nuclear Smuggling," in Beyond Sovereignty, ed. Maryann K. Cusimano, 224.

${ }^{138}$ Sam Nunn, "Last Best Chance," http://www.nti.org, 2005 (accessed August 15, 2005). 
well as threatening to use radioactive material and devices, and the attempt to obtain them (all of them referring to international terrorism). While governments still seem to be relatively successful in keeping the nuclear threat under control, biological and chemical weapons present an even greater danger to individual countries and the international community.

\section{III.2.c.ii. Chemical terrorism}

As experts have repeatedly underscored, "[t]he cost of acquiring a stockpile of chemical or biological weapons is small when compared with the cost of achieving nuclear capability" (while the death toll is potentially the same) and "defensive biological and chemical programs can provide cover for covert offensive $\mathrm{BW}$ and $\mathrm{CW}$ programs. ${ }^{\text {"139 }} \mathrm{As}$ the 1995 Sarin gas terrorist incident on the Tokyo subway demonstrated, attacks with weapons of mass destruction employed by terrorist groups are not only conceivable, but even likely to be repeated in the future. Similar to the case of Jihadist groups, the Japanese group that perpetrated the attacks on Tokyo's transit system (Aum Shinrikyo) was also religiously motivated; in the same fashion, the fundamentalist beliefs of its members led them to seek a high death toll to advance their ultimate objectives (although some of their motives are still left unexplained).

The threat of attacks with chemical weapons is significantly higher than the threat of nuclear terrorism given not only the availability of chemicals that can be employed in terrorist incidents or military operations, but also the fact that "[a] variety of chemicals

${ }^{139}$ Patrick Clawson (editor), Strategic Assessment 1996: Elements of U.S. Power, 200. 
can be used, from lethal ones such as nerve gas to merely irritating ones such as tear gas." ${ }^{\prime 140}$ It is for these reasons and the associated threat of using such readily available means of violence that chemical weapons are often called "the poor man's atomic bomb."

The 1993 Chemical Weapons Convention, an arms control agreement meant to ban the production, acquisition, stockpiling, transfer and use of chemical weapons throughout the world, has been signed by a large majority of today's states. But the threat posed by chemical terrorism is still unresolved, since groups potentially perpetrating this type of violence are not, nor do they intend to be, signatories to this convention (nor are they offered this status, for that matter). Biological weapons are generally treated similarly to chemical weapons and are included in the same class of weapons of mass destruction.

\section{III.2.c.iii. Biological terrorism}

The employment of biological weapons for military/terrorist purposes is also known as germ warfare and it is based on the use of microorganisms or biologically-derived toxins (rather than chemical substances). According to many recent studies and simulations, "a single weapon could spark an epidemic in an entire population"141 and "there is good reason to fear that biological weapons could become the weapon of choice for terrorists, $" 142$ as emphasized by US Secretary of Defense William J. Perry in late 2001.

\footnotetext{
${ }^{140}$ Joshua S. Goldstein, International Relations (New York: Longman, 2002), 196.

${ }^{141}$ Ibid., 198.

${ }^{142}$ William J. Perry, "Preparing for the Next Attack," 32.
} 
Not only that intelligence sources indicate that groups around the world try actively to develop effective biological weapons for terrorist purposes, but also "the sophistication of biological weaponry has improved by leaps and bounds. [...] biology in the last decade has been what physics was in the 1940s and 1950s: a field of exponential discovery."143 New and much more complex types of biological agents have been created and can potentially be obtained and employed by terrorist groups in attacks on urban areas or military camps and personnel.

There are experts arguing that a terrorist incident using such weapons would likely not result in mass casualties (although other scholars would oppose strongly such a view). Yet even if biological or chemical weapons would not kill large numbers of people, Christopher Bellamy argues that their unreliable and indiscriminate character would not make them less useful for terrorist purposes: "[t]hat might not deter terrorists because their aim is not [necessarily] efficient killing,"144 but spreading terror, which could hurt much larger numbers of individuals and societies indirectly. As a consequence, the response to the threat of attacks with biological and chemical weapons has to be multifaceted, involving multiple layers of policy frameworks and organizational structures.

Experts indicate that the 1972 Biological and Toxin Weapons Convention, which prohibits the creation and storage of biological weapons, does not prohibit their actual

\footnotetext{
143 Laurie Garrett, "The Nightmare of Bioterrorism," Foreign Affairs, vol. 80, no. 1 (January/February 2001), 76.

144 ***, "Terrorist WMD Attacks Might Not Cause Mass Casualties, British Scientists Say," http://www.nti.org, 2005 (accessed August 24, 2005).
} 
use. Many governments and organizations called for revamping this international instrument, which seems outdated and inefficient. The Red Cross also called for the strengthening of this convention "to more effectively deter state bioweapons programs," along with bioterrorism - in the words of Peter Herby, chief of the Red Cross MinesArms unit, "[s]cience is moving at a tremendous speed but the diplomatic process is generally frozen."145 Yet efforts to prevent the proliferation of WMD are still an important part of governments' and international organizations' strategies in addressing today's international security concerns. ${ }^{146}$

Officials and experts from around the world convene regularly to assess the threat of WMD terrorism and to discuss appropriate measures of counteracting it. Preventing proliferation of weapons of mass destruction, i.e., depriving terrorist groups of some of the means to conduct their violent acts, is one of the key priorities on the countries' agendas in relation to this challenge. There have been many calls in recent years, from various governments and NGOs, to strengthen international arms embargos and to create additional mechanisms that would prevent organizations such as al-Qaeda from acquiring and using WMD.

$145 * * *$, "Red Cross Calls for Strengthening of Biological Weapons Treaty to Better Regulate Against Weapons Programs," http://www.nti.org, 2005 (accessed September 20, 2005).

${ }^{146}$ The 1968 Nuclear Non-Proliferation Treaty is a useful starting point in discussing WMD proliferation concerns. Several other instruments and programs were initiated during the 2001-2006 period to deal with this issue, such as the G8 Global Partnership against the Spread of Weapons and Materials of Mass Destruction, concluded at the G8 Kananaskis Summit, in Canada, in June 2002. 
A United Nations report, released in September 2005, points out that "[t]errorist tactics have evolved over the past several years" and "the arms embargo should change with the times;" the report also warns that "al-Qaeda's 'third generation' $[\ldots]$ is looking to carry out large-scale attacks in order to generate publicity." 147 The Proliferation Security Initiative (PSI), created in 2003 by several (mostly Western) countries, at the initiative of the United States, is an alternative instrument meant to stop the flow of WMD and related materials - among others, through control of marine shipments - so that terrorist groups and rogue states have limited access to such means of violence. These measures reflect the concern shared by governments around the world about an increasingly unstable and dangerous international security context, one in which WMD terrorism has become the most recognizable threat.

Nonetheless - as indicated earlier in this chapter - the view that terrorism ranks highest as a security threat is not universally accepted. Some analysts point to the existence of other security challenges, which they consider at least as significant as terrorism: pandemics, climate change, organized crime, conventional nuclear proliferation, interstate military rivalry, competition over finite energy resources, cyber-threats, etc. In his book titled The Upside of Down, ${ }^{148}$ Thomas Homer-Dixon lists five "tectonic stresses" that threaten today's global order: energy stress, economic stress, demographic stress, environmental stress and climate stress.

147 ***, "U.N. Must Sharpen Response to Evolving 'Third Generation' al-Qaeda Tactics, Report Says," http://www.nti.org, 2005 (accessed September 21, 2005).

${ }_{148}$ Thomas Homer-Dixon, The Upside of Down: Catastrophe, Creativity and the Renewal of Civilization (Toronto: Knopf Canada, 2006). 
Together, these factors and other multipliers represent a potentially "lethal mixture," increasing "the risk of a cascading collapse of systems vital to our wellbeing" - what he calls "synchronous failure." 149 In a review of Homer-Dixon's book, Will Kymlicka notes, however, that the author "acknowledges the limits of our knowledge, the depth of scholarly disagreements and the difficulty of making accurate predictions." ${ }^{, 150}$ Such disagreements amongst scholars and practitioners, combined with a limited number of terrorist incidents following the events of $9 / 11$, led some analysts to the conclusion that Western governments should not be overly concerned with terrorism.

Columnist Gwynne Dyer talked about an "international terrorist conspiracy" following the events of September 11, 2001: "there is no shadowy but powerful network of international Islamist terrorists waging a war against the West," only "small groups of extremists who blow things up once in a while." ${ }^{151}$ In Dyer's view, it was just the "fluke success of the $9 / 11$ attacks [that] created the illusion that terrorism was a major problem." "152 "[T]errorism itself is only a minor threat," he argued; "the threat continue[d] to be seen as huge and universal" only through "relentless official propaganda" by the United States government. ${ }^{153}$

\footnotetext{
149 Thomas Homer-Dixon, "The Argument," http://www.theupsideofdown.com/, 2006 (accessed October $15,2007)$.

${ }^{150}$ Will Kymlicka, "Panarchy and dystopia," The Globe and Mail, November 11, 2006.

${ }^{151}$ Gwynne Dyer, "The International Terrorist Conspiracy," http://gwynnedyer.net/, June 3, 2006 (accessed August 22, 2007).

${ }^{152}$ Gwynne Dyer, "If 9/11 Hadn't Happened," http://gwynnedyer.net/, September 2, 2006 (accessed August $22,2007)$.

${ }^{153}$ Gwynne Dyer, "Perspectives on Terrorism," http://gwynnedyer.net/, July 1, 2007 (accessed August 22, 2007).
} 
Ohio State University political scientist John Mueller went even further, suggesting that an entire "terrorism industry" (made up of the media, the bureaucracy, business and politicians) inflates national security threats: "your chances of being killed, at present rates, by an international terrorist outside of a war zone is something like one in 80,000 . It's about the same as being killed by an asteroid." $9 / 11$, he argued, was a "spectacular exception to what terrorists have been able to do;" yet he acknowledged that the consequences of WMD terrorism "could be very high, so putting a certain amount of money in that area certainly makes a fair amount of sense." 154

Most officials and analysts would disagree with the views of sceptics such as Gwynne Dyer and John Mueller: such perspectives, while notable, remain exceptions in a field dominated by concerns over the consequences of terrorism, WMD proliferation and failed and failing states. In a Western context, this combination of threats is perceived as originating primarily from outside, in a physical and/or ideological form; yet it is the nature of these new security challenges, crossing national boundaries, that questions the appropriateness of Michael C. Desch's distinction between internal and external threats. An argument can be made that external factors can be conceptualized as threats because of the new danger they pose to Western homelands. They have both an internal and external dimension; this interconnectivity, Rod Lyon argues, is "a worrying element [...] for it suggests that neither dimension of the threat, external or internal, can be addressed singly," 155 which presents the potential of complicating the policy-making process. The

\footnotetext{
${ }^{154}$ John Mueller, as quoted in Terror Nation: Are Americans Allowing Terrorists to Rule Their Lives?, by John Stossel and Gena Binkley, http://abcnews.go.com/2020/story?id=2895849\&page=1, February 23, 2007 (accessed August 22, 2007).

${ }^{155}$ Rod Lyon, "Civil-Military Relations in an Age of Terror."
} 
following sections of this chapter will investigate the nature of the post-9/11 threats in a Canadian and Romanian context.

\section{III.3. Case study: Canada}

\section{III.3.a. Introductory remarks}

Canada perceived the realities of the early post-Cold War period in the same light as most other Western countries: as an era of uncertainty, of blurred security challenges and policy priorities, of disquieting deterioration of the ability of many states to provide political goods to their citizens (including security), of new threats and adversaries - an era in which what had appeared to be the basics in the security and defence arena during the Cold War were no longer entirely relevant. The disintegration of the Soviet Union ushered in a new world order, one whose fundamental essence was to be discovered and actively redefined in capitals around the world. For Ottawa, it meant the likely reduction in the threat of nuclear war and - it was thought in the early $1990 \mathrm{~s}-$ the possible dawn of an age of peaceful international cohabitation. Senator Raoul Dandurand's 1920s idea of Canada living in a "fire-proof house far from flammable materials"156 was once again given credit in what would eventually prove to be an overly optimistic assessment of the post-Cold War international situation.

\footnotetext{
${ }^{156}$ As quoted in "Dandurand revisited; rethinking Canada's defence policy in an unstable world," by Joseph T. Jockel and Joel J. Sokolsky, in International Journal, vol. 48 (Spring 1993), p. 117.
} 
In the words of Lt.-Gen. (ret'd) Richard J. Evraire, Chairman of the Conference of Defence Associations, "[w]ith the sudden end of the Cold War and the collapse of its accompanying bi-polar framework, the world entered a period of great uncertainty. Now alliances shift and threats arise or recede as actors attempt to identify their new roles in international affairs. A new pattern of stability is being sought; an elusive goal to be sure." ${ }^{\prime 157}$ Slowly but surely, as the amazement and excitement over the end of the Cold War diminished, countries such as Canada realized that new yet equally formidable security challenges were just around the corner. A key difficulty for governments, academics and other experts during the post-Cold War period was presented by the wide array of threats, which prevented analysts and policy makers from crafting a clear hierarchy of security and defence priorities. From traditional military threats and interstate conflicts to weapons of mass destruction and cyber-terrorism to pandemics and environmental degradation, the risk factors formed a bowl of intermingled security challenges.

Some threats received, however, from the early stages of the post-Cold War era a higher degree of attention, chief among them Islamic fundamentalism and the proliferation of weapons of mass destruction. Citing "several CSIS [Canadian Security Intelligence Service] reports," Rob Huebert argues that, during the 1990s, "the Canadian government had warnings of [these] threats, but ignored them until September $11^{\text {th }} . " 158$ Other analysts added to the list of key concerns during the 1990s failed and failing states, regional

${ }^{157}$ Lt.-Gen. (ret'd) Richard J. Evraire, "Security in a New Era: Rethinking Canadian Defence and Foreign Policy," On Track, vol. 7, no. 3 (October 9, 2002), 18.

${ }^{158}$ Rob Huebert, "New and formidable challenges require new and fresh thinking," On Track, vol. 7, no. 4 (December 20, 2002), 22. 
conflicts and organized crime activities - alongside human security, actively promoted by Government and leading academics. Paraphrasing Gen. Rick Hillier's description of the recent security environment, Brigitte Pellerin draws the comparison between the bear (the Cold War adversary) and the snakes (the post-Cold War enemies): "The threat out there is no longer the bear [massed armoured battle]; the threat now is a bowl of snakes, the slippery mixture of terrorists, insurgents and organized crime we find in failed and failing states. It's multinational, it's an information battle, it's an insurgent battle."159

What was striking to both policy makers and scholars was the sudden and largely unexpected shift from traditional approaches on security and defence matters (prevalent for many decades prior to 1989-1991) to a necessary focus on asymmetric threats and unconventional military responses. In the post-9/11 era, threats such as terrorism and WMD proliferation have been transformed from one category in a long list of potential security challenges that the world had dealt with into the key security concerns of Western countries, Canada included. Most other threats have become peripheral elements in an international security context that is widely perceived as a radical departure from the Cold War era - the decade following the end of the Cold War only served as a period of transition between two distinct types of world order.

III.3.b. The Canadian perspective on the new security environment

The fact that not only the United States was concerned, among Western countries, with threats such as terrorism was tragically demonstrated by terrorist attacks against countries

${ }^{159}$ Grigitte Pellerin, "Help for our reserves," National Post, September 9, 2005. 
such as Spain (Madrid, March 11, 2004) and England (London, July 7 and July 21, 2005).

A particular cause of concern in Ottawa was that, among the six countries that al-Qaeda leader Osama bin Laden listed in a November 2002 audio message as legitimate targets for terrorist attacks (Britain, France, Italy, Germany, Canada and Australia), because of their support for the US-led military intervention in Afghanistan, ${ }^{160}$ Canada was the only one that had not suffered a strike. A Canadian intelligence report produced by the Integrated National Security Assessment Centre (INSAC) and disclosed to National Post under the Access to Information Act noted that al-Qaeda ranked Canada, in March 2004, as "the fifth most important Christian country to be targeted, following the U.S., the U.K., Spain and Australia."161 This caused anxiety amongst Canadians and led policy makers, security analysts and the broader public to declare the possibility of Canada suffering terrorist strikes as real. ${ }^{162}$ In a 2005 study on threat perceptions in Canada and the United States, Frank Graves of EKOS Research Associates argued that, in the two countries, "attitudes to threat and security reveal more impressive areas of similarity than difference. $[. .$.$] Americans and Canadians are largely consistent in their belief that the$ world is a more threatening place today than in the recent past. Certainly 'terrorism' is a key ingredient of this deeper sense of dread." 163

Calling the mention of Canada in bin Laden's list of countries to be attacked by al-Qaeda "a chilling reminder" of the nature of the new international threat environment, Deputy

\footnotetext{
${ }^{160}$ Rob Gilroy, "Canada should heed bin Laden's warning: Experts," CTV News, November 14, 2002.

${ }^{161}$ Stewart Beil, "Deportations put Canada at risk of attack," National Post, Nov. 22, 2004.

162 Dwight Hamilton (ed.), Inside Canadian Intelligence: Exposing the New Realities of Espionage and International Terrorism, Toronto: Dundurn Press Ltd., 2007, 22.

${ }^{163}$ Frank Graves, "U.S. and Canadian Outlooks on Threats: Coherence or Contradiction?," One Issue, Two Voices (Woodrow Wilson International Center for Scholars), issue 4 (October 2005), 17.
} 
Prime Minister and Minister of Public Safety and Emergency Preparedness Anne McLellan urged Canadians to be on guard: "while Canada may not be a primary target for a terrorist attack, we are a named target." ${ }^{164}$ While Anne McLellan had downplayed the risk of attacks against Canada and Canadians after the Madrid terrorist incidents of March 2004, she clearly indicated a higher likelihood of such events happening after the London strikes of July 2005. Gen. Rick Hillier, Chief of the Defence Staff (CDS), went one step further: he said Canada had "a very big profile" on the international stage even without its military involvement in Afghanistan - by just being a liberal democracy that represents "the exact opposite of what people like Osama bin Laden, Mullah Omar and those others want" would make the country a clear target for future terrorist attacks. ${ }^{165}$

Gen. Rick Hillier argued for decisions to be made so that Canada responds appropriately to a qualitatively different international threat environment: Canadians, he said, "are at more risk now of direct attack than they have ever been during the Cold War itself."166 Even when disagreeing over the level of threats to Canada and Canadians, Anne McLellan and Gen. Hillier shared the same view on these menaces - originating beyond the country's borders. This idea is emphasized by many government analysts and nongovernmental experts, who believe that international terrorism poses a serious challenge to Canada's security and stability and that its roots can be discovered ideologically in Islamic fundamentalism and geographically in predominantly Muslim

\footnotetext{
${ }^{164}$ Anne McLellan, "Securing Canada: Laying the groundwork for Canada's first National Security Policy," speaking notes to the Canadian Club of Ottawa, Ottawa, March 25, 2004.

${ }^{165}$ Stephen Thorne, "London attacks underscore Canada's need to be in Afghanistan: Hillier," National Post, July 14, 2005.

${ }^{166}$ Lt.-Gen. (ret'd) George Macdonald, “Canada-US Defence cooperation: Where to from here," Canadian Military Journal, vol. 6, no. 2 (Summer 2005), 10.
} 
countries. Yet, although leaning toward an assessment of the new threat environment along the lines of high external and low internal threats, this thesis concludes that the interconnectivity of domestic and international factors makes the internal/external distinction difficult to support analytically.

Similar to the US Central Intelligence Agency (CIA), the Canadian Security Intelligence Service and the Royal Canadian Mounted Police (RCMP), as key government organizations in charge of counteracting threats to Canada and its citizens, repeatedly noted that major security challenges such as international terrorism originated predominately abroad, but could materialize at home. All public reports by Canadian intelligence agencies indicated that the threat had not disappeared - on the contrary, it was on the rise - in the first five years following 9/11. Two 2005 studies by Canada's military intelligence $\operatorname{arm}^{167}$ and by the Government's Integrated Threat Assessment Centre $^{168}$ even suggested the possibility of terrorist organizations such as al-Qaeda attempting to use biological agents such as the deadly $\mathrm{H} 5 \mathrm{~N} 1$ avian influenza virus to jumpstart a pandemic among Western populations.

An important voice in the discussion of threat levels in post-9/11 Canada was Colin Kenny, Chairman of the Standing Senate Committee on National Security and Defence (established in March 2001). He repeatedly warned about the likelihood of terrorist strikes on Canadian territory and called for higher levels of funding in the areas of

167 ***, Recent Human Outbreaks of Avian Influenza and Potential Biological Warfare Implications, cited in "Canada warns of avian influenza used as weapon," http://www.chinaview.cn, March 9, 2005 (accessed March 9, 2005).

168 ***, Pandemics: Avian Flu, cited in Stewart Bell, "Al-Qaeda could spread avian flu, report warns," National Post, October 25, 2005. 
security and defence. "There are only two certainties. The first is that big bad moments will come to Canada. The second is that Canadians are unprepared," a report by Colin Kenny's Senate committee stated in $2004 .{ }^{169}$ The committee based its conclusions on discussions with intelligence and security experts, and reports and assessments provided by government and nongovernmental organizations working on security and defence issues.

Colin Kenny argued that Canadian official assessments indicating significant levels of threat to the country's security were credible, given the fact that they were corroborated by US and British government reports: "They were not equivocal about it all. They said you're on the list, just like we're on the list. You're active in the war on terror. [...] AlQaeda has named you. The way you live, your culture, will make you a target." ${ }^{\text {170 }}$ While various commentators questioned the credibility and even the appropriateness of $\mathrm{Mr}$. Kenny's comments, the fact remained that having access to reliable (although generally declassified) information put him in a position to present convincing arguments about the nature of threats, threat levels and emergency preparedness.

There are, of course, scholars and security analysts who think officials are biased in their assessments of the new threat situation - either because of the institutional environment the latter work in, personal interests or because of their organizations' internal agendas. Wesley K. Wark of the University of Toronto argued, for instance, that al-Qaeda would have a hard time conducting terrorist activities in Canada, especially recruiting home-

\footnotetext{
${ }^{169}$ Mohammed Adam, "Prepare for catastrophe or pay with lives: reports," Ottawa Citizen, Nov. 27, 2004.

${ }^{170}$ Glen McGregor, "Judging terrorism's real threat to Canada," Ottawa Citizen, December 14, 2004.
} 
grown operatives in the country, given the more moderate political character of Canadian Muslims; Charles Strozier of New York's John Jay College of Criminal Justice suggested as well that Canadian Muslim communities are not committed to violent action ${ }^{171}-$ the threat would come, however, from outside.

David A. Charters of the University of New Brunswick went one step further, saying that there are no terrorist groups (except maybe al-Qaeda) willing to target Canada or Canadians specifically - inter alia because Canada "carries very little weight in the world;" even so, he acknowledged that "Canada is at some degree of risk because we share a common border [with the USA] and because our economies and infrastructure are so closely integrated." 172 Roger Congleton of George Mason University argued that resources were allocated in trying to counter an elusive threat such as terrorism and that the threat-related discourse was exaggerated: "saying 'Toronto subject to an attack' wouldn't be false, but it would be exaggerated in terms of whether that's a likely event." ${ }^{, 173}$ Overall, while arguing over threat levels, experts largely believe that Canada is potentially under attack and that policy makers and the population at large should adopt this frame of thinking and take appropriate measures to counteract threat situations.

\footnotetext{
${ }^{171}$ Don Butler, "How middle-class westerners are turned into human bombs," Ottawa Citizen, July 14, 2005.

${ }_{172}$ David A. Charters, "The Impact of the War on Terrorism on the Canadian-American Security Relationship," paper presented at the conference Canadian Defence and the Canada-U.S. Strategic Partnership, organized by the Centre for Security and Defence Studies (CSDS) at Carleton University, the Calgary-based Canadian Defence \& Foreign Affairs Institute (CDFAI) and the Center for the Study of the Presidency in Washington, DC, Lord Elgin Hotel, Ottawa, September 5-6, 2002.

${ }^{173}$ Cited in: Glen McGregor, "Judging terrorism's real threat to Canada," Ottawa Citizen, December 14, 2004.
} 
"We do have a number of things I think in our country which they [terrorists] would say are significant in terms of the struggle they see themselves waging," Martin Rudner of Carleton University pointed out. ${ }^{174}$ Akbar Ahmed of American University in Washington, D.C., and Boaz Ganor of the International Policy Institute for Counter-Terrorism in Israel added another element to this equation: if the United States becomes increasingly difficult to strike by terrorist groups, an attack against Canada, maybe close to the US border, might be the next best thing. In the words of Mr. Ganor, Canada is, "if not a primary target, a very worthy target. [...] If it is harder to attack in the United States, it is not inconceivable, from the point of view of these guys, to attack Canada."175 Graham Allison raised the possibility of Canada being "the target of a nuclear terrorism bomb" or "[e]ven more likely" of being used as a transit country for a WMD terrorist attack against the United States, since the two countries share "a border that resembles Swiss cheese but with more holes than cheese."176

The intensification of terrorist attempts to strike Western countries prompted authorities in Canada to ask the public to brace for possible incidents at home. While the Madrid attacks of March 2004 led to concerns expressed in public and behind closed doors about complacency related to prevention measures and emergency preparedness, the watershed moment came with the July 2005 attacks on the London transit system. Given Canada's historic links to the United Kingdom (UK), on multiple levels, a series of four suicide

\footnotetext{
${ }^{174}$ Gloria Galloway, "Experts caution al-Qaeda may hit at targets in Canada," The Globe and Mail, July 9, 2005.

${ }^{175}$ Peter Goodspeed, "Canada seen as having 'soft belly,' terror expert says: 'Very worthy target'," National Post, November 3, 2005.

${ }^{176}$ Graham Allison, "Is nuclear terrorism a threat to Canada's national security?," International Journal, vol. 60, issue 3 (Summer 2005), 20.
} 
bombings in London that killed more than 50 people and wounded about 700 (followed two weeks later by four unsuccessful strikes) was perceived in Canada as the most important event of its kind after 9/11.

Canadian officials were quick to emphasize the seriousness of the threat and the vulnerability of all liberal democratic societies. "Canadians are not immune to what we see happen in London, Madrid, 9/11. We are not immune to that kind of terrorist violence," Anne McLellan, Minister of Public Safety and Emergency Preparedness, argued in what analysts described as "the first time a federal minister [spoke] so forcefully on the issue." ${ }^{177}$ A purported Taliban video showing Afghan and Pakistani militants ready to depart on suicide missions in Canada, the United States and Europe (dated 2007) determined Martin Rudner to urge the Canadian Government to take such external threat seriously: “[a]s we have a counter-terrorism coalition, they have a Jihadist coalition." 178

Five years earlier, in an analysis of the new threat environment, Elinor Sloan of Carleton University had already provided a detailed picture of the North American security context. She argued that new threats emerged primarily from individual terrorists rather than states and that threats could be seen as "doubly asymmetric," since they could potentially involve "not only unconventional parties (terrorists) but also unconventional means (weapons of mass destruction)." ${ }^{, 179}$ In her comprehensive 2005 book Security and

\footnotetext{
${ }^{177}$ Mohammed Adam, "Canada must expect attack: McLellan," Ottawa Citizen, July 12, 2005.

${ }^{178}$ Ian Macleod, "Officials pore over Taliban 'grads' video," Ottawa Citizen, June 20, 2007.

179 Elinor Sloan, "Land Threats to North America and the Role of the Army," paper presented at the conference Canadian Defence and the Canada-U.S. Strategic Partnership, organized by the Centre for
} 
Defence in the Terrorist Era, Elinor Sloan argued that "[t]he nature of the threat to North America today is such that its origins are most often found abroad" - the most important threat is represented by "international terrorism, and specifically individuals and networks of individuals operating in terror cells dispersed around the globe. $" 180$

This latter idea is expressed in a majority of studies on post-9/11 threats: most scholars and policy makers emphasize the external origins of security threats to Western countries, but also their potential to manifest themselves on domestic soil. It is, in the end, the aim of this new enemy to strike at Western interests broadly, but with particular attention being often devoted to reaching Western homelands. The very events of September 11, 2001, were a clear exemplification of this: the terrorists perpetrating the attacks were individuals motivated by beliefs that were foreign to the vast majority of North American and European people; they did not hold US citizenship, but they carried out the $9 / 11$ attacks from within the United States, against American targets. One of the things that 9/11 brought about was the idea that oceans no longer constitute a security buffer, as the enemy can strike from within - North Americans lost the relative sense of invulnerability that had characterized the view of their place in the world, at least during the early postCold War years. ${ }^{181}$ The continent, and by extension the Western world, became once

Security and Defence Studies (CSDS) at Carleton University, the Calgary-based Canadian Defence \& Foreign Affairs Institute (CDFAI) and the Center for the Study of the Presidency in Washington, DC, Lord Elgin Hotel, Ottawa, September 5-6, 2002.

${ }^{180}$ Elinor C. Sloan, Security and Defence in the Terrorist Era (Montreal: McGill-Queen's University Press, 2005), 112 and 133.

${ }^{181}$ Particularly in the post-9/11 threat environment, as opposed to the Cold War era, deterrence lost its usefulness as a security strategy. While during the Cold War North America was vulnerable to Soviet attacks using ballistic missiles, the enemy feared military retaliation against its own targets. Yet deterrence is less likely to work as a counter-terrorism strategy, given the potential aggressors' apparent willingness to die for their causes, their disregard for human life and the amorphous nature of terrorist organizations. 
again the target of another ideological movement, a challenge - some would argue - at least as difficult to counteract as the Soviet threat.

\section{III.3.c. Post-9/11 security concerns in Canada}

Just as Communism led after the Second World War to new views in the West about the nature of security challenges (an environment conducing eventually to a nuclear standoff between ideologically-distinct groups of nations), terrorism and associated threats shape the perception of the post-9/11 international situation and dictate its fundamental principles. The United States has been the key actor - as a victim and as an active participant - in the new conflict opposing liberal democratic societies and Islamic fundamentalist groups.

Both as a leading member of the Western community and as a neighbour of the United States, Canada had no other choice than to re-evaluate its place in the new world order and to react accordingly. When the war against terrorist and insurgent groups became the existential preoccupation of Western countries in the new international security environment, Canada quickly found itself at its forefront. Canadian officials explained the need for the country's involvement in an international campaign against global terrorism, emphasizing the earthshaking nature of September 11, 2001. Five years after 9/11, Prime Minister Stephen Harper told the United National General Assembly that terrorism remained the main threat of this new era and that success in the multinational mission in Afghanistan "leads the list" of challenges facing the international community. 
"If we fail the Afghan people, we fail ourselves," he said, explicitly linking the domestic security of liberal democratic societies with developments in far-away places. ${ }^{182}$

Other government officials and independent experts stressed the fact that the sense of invulnerability previously enjoyed by Canada, as a country protected by three oceans and a friendly neighbour, was shattered on September 11, 2001, along with the United States'. As Prime Minister Paul Martin put it in 2004, “[t]ogether, we have come to realize that the world is smaller since $9 / 11$. It is more complex, more perilous, more challenging. [...] This is not a conventional war and the ocean is no longer a buffer. We do not see the enemy. He does not wear a uniform. He seeks only to kill. And thus, we must be steadfast and unrelenting in our vigilance." 183 In the new strategic environment, Canada realized it had a duty not only to protect its territory and its citizens from terrorism and related threats, but also to prevent attacks against its southern neighbour.

"We're talking about an existential threat to the whole of the human family," Justice Minister Irwin Cotler was quoted as saying in 2005 , in reference to terrorism. ${ }^{184}$ Like $\mathrm{Mr}$. Cotler, the majority of top government officials and most other experts recognized the deep significance of the terrorist strikes against the United States and the profound consequences of those actions for the priority agenda and the working of the international community. The extraordinary interest in tackling this threat (out of a wide array of threats facing Western countries) is related not only to its potential for violence, but also

\footnotetext{
${ }^{182}$ Kathleen Harris, "We cannot afford to fail," The Ottawa Sun, September 22, 2006.

183 ***, "Address by Prime Minister Paul Martin at Pier 21, Halifax," http://www.news.gc.ca/cfmx/view/en/index.jsp?articleid=113169\&keyword=pier+21\&keyword=pier+21\&, December 1, 2004 (accessed November 21, 2005).

${ }^{184}$ Dan Gardner, "Irrational spending in the Age of Terror," Ottawa Citizen, February 19, 2005.
} 
to its nebulous nature. As Capt. (N) Peter Avis and Iain Grant pointed out, "[s]ince the struggle against international terrorists does not focus on sovereign states in particular, the battle space becomes both local and federal, domestic and international, sensational and commonplace" and it is imperative that the response involve both "brains" and "brawn." As a consequence of the emergence of this indeterminate security environment, Canada initiated multi-level measures, both domestically and internationally, to address the threat of terrorism.

In only a few months following the $9 / 11$ attacks, Canada passed legislation freezing terrorist assets in the country, making terrorist fundraising more difficult and allowing law-enforcing agencies to "crack down" on radical organizations and individuals (e.g., the Anti-Terrorism Act or Bill C-36). It created new organizations to deal with the new threat situation, such as an Ad Hoc Committee of Ministers on Public Security and AntiTerrorism and increased dramatically funding for security upgrades (initially in the area of airport and air security). These moves were followed in subsequent years by new policies and institutions created specifically to deal with post-9/11 challenges.

As important steps in counteracting the threat posed by terrorism, Canada created a Department of Public Safety and Emergency Preparedness (PSEPC), an Integrated National Security Assessment Centre, a National Security Advisory Council, a Cabinet Committee on Security, Public Health and Emergencies, a Cross-Cultural Roundtable on Security, a federal-provincial-territorial forum on emergencies and a new position of

${ }^{185}$ Capt. (N) Peter Avis and Iain Grant, "Canadian Maritime Security and the Culture of Prevention," Canadian Military Journal, vol. 5, no. 4 (Winter 2004-2005), 56. 
National Security Advisor to the Prime Minister. All these changes were driven by what Prime Minister Paul Martin saw as a key focus of his government's activity: "the priority is what can we do now in the fight against global terrorism, in the protection of our coasts, in making sure we have the intelligence information that we require to defend Canada." 186 Along with a 2004 new National Security Policy (NSP) and a 2005 International Policy Statement (IPS), other changes were initiated by the two Liberal governments - under Jean Chrétien and Paul Martin - to deal with the challenges posed by the post-9/11 threat environment.

Among these changes, significant funding ( $\$ 8$ billion over five years) was announced for measures to be taken in Canada's security, defence and intelligence sectors. Nonetheless, in that initial phase, the Canadian Forces saw no significant defence spending increase. Then-Minister of Foreign Affairs John Manley noted that, in late 2001, the priority "was how do we make sure we are not seen as the source of weakness and threat to the Americans. $" 187$ Military-related funding was allocated in 2001 to improve critical infrastructure protection and emergency preparedness, and to strengthen special operations forces ( $\$ 1.6$ billion); further increases in defence spending would be announced in following years. Restructuring the country's government structures to deal with the new threats involved massive changes and led to the creation of new institutions and policies, as exemplified above. All these changes were triggered by, and were a direct reaction to, a radically changed threat environment, both domestically and externally. They also serve to prove the extent to which authorities thought it necessary to

\footnotetext{
${ }^{186}$ Peter O'Neil, "Martin denies missile shield is a top issue," Ottawa Citizen, November 15, 2004.

${ }^{187}$ Cited in: Janice Gross Stein and Eugene Lang, The Unexpected War, 7.
} 
respond to what they (and the public at large) perceived to be a new hierarchy of security challenges at home and a novel world order. "Security threats are very real," Prime Minister Stephen Harper would say in a June 2006 interview. "This country is as much [a target] as the United States. That's why not only is the Government acting nationally against terror threats, but we're also working globally in Afghanistan and all over the world to deal with this problem." 188

In what was widely viewed as a radically transformed global security climate, the need for novel institutions and policies was acknowledged by most policy makers and experts: inter alia, " $[t]$ he result is that the need for an interdepartmental approach to security and emergency planning - which might have seemed innovative thinking a few short years ago - is now largely axiomatic." 189 The creation of the Department of Public Safety and Emergency Preparedness in 2003 served precisely that purpose: to act as an interface between the various government organizations with responsibilities in security-related areas and to ensure multi-level and inter-agency policy coordination. In addition to this, there were requests and initial plans implemented for the creation of a separate Canadian foreign intelligence service, a secret electronic network for confidential informationsharing among government organizations (dubbed Canadian Secret Network), a new military command structure (known as Canada Command) and expanded special operations forces (e.g., Joint Task Force Two or JTF2).

\footnotetext{
${ }^{188}$ David Walton, "Security forces can confront terror threat head on, PM says," The Globe and Mail, June $10,2006$.

${ }^{189}$ Capt. (N) Peter Avis and Iain Grant, "Canadian Maritime Security and the Culture of Prevention," 58.
} 
Given traditional institutional conservatism, the breath of these changes in just a five-year period is remarkable. They emphasize, once again, the extent to which $9 / 11$ was a turning point in what had been an amorphous threat environment. Canada's many and varied responses following the events of $9 / 11$, at home and overseas, also serve to underscore the extent to which the government perceived the new era as a radically changed security context. Such responses were initiated in order to tackle security challenges of a mostly external nature, but threatening Canadian interests abroad and the Canadian homeland.

Of the list of threats identified by Canada as chief security concerns, terrorism has received the most official and public attention. However, during the 2001-2006 period, no terrorist incidents occurred in Canada, no person was convicted of terrorism-related activities and no obvious signs were noted indicating terrorism as a growing, widespread domestic threat. There were a number of well-publicized cases, neither of which was necessarily part of a larger trend toward radicalization of various groups within Canadian society or intensification of terrorist-related activity within Canadian borders. Despite the fact that the Financial Transactions and Reports Analysis Centre of Canada (FINTRAC) said it had detected several suspected terrorist-financing networks operating in the country, by early 2008 no group or individual was convicted of financing terrorism (the practice had been outlawed in 2001). ${ }^{190}$

The most well-known case during this timeframe involved the arrest of seventeen terror suspects in Toronto, in the summer of 2006, in which an alleged bomb plot was thwarted. Twelve men and five teenagers were charged with various security-related offences -

${ }^{190}$ Stewart Bell, “Terror Financing on the Rise," National Post, October 5, 2006. 
authorities claim that the home-grown group with allegedly external links to al-Qaeda wanted to detonate bombs in downtown Toronto, storm the Parliament in Ottawa, kidnap politicians and decapitate the Prime Minister if their demands for Canadian troops being withdrawn from Afghanistan were not met. By mid-2008, no convictions were reached in this case and some of the accused were released on bail.

Terrorism expert David Harris pointed out in a June 2006 interview that the alleged terrorist plans underscore, if anything, the external connections of Islamic fundamentalism in Canada: "radical Wahhabist Saudi money is being injected into certain Canadian mosques and Islamic facilities. There seems to be a connection between that sort of influx of cash and radicalism." ${ }^{.191}$ In this context, Canadian officials have repeatedly emphasized that international cooperation - alongside devising and implementing domestic measures - is crucial in the fight against global terrorism. Most empirical evidence available to officials and independent researchers indicate the existence of complex networks of transnational terrorist organizations. In a separate case, Momin Khawaja, a former computer contractor with Canada's department of Foreign Affairs, was charged in 2008 (after being arrested in 2004) under the country's AntiTerrorism Act, being accused of involvement in an international plot to detonate a bomb in London, UK. ${ }^{192}$

Information from other cases tends to validate the idea of the transnational nature of these new threats. A 2004 Operation Canyon helped unveil secret links between terror suspects

\footnotetext{
${ }^{191}$ Interview with David Harris, by Lida Frum, Maclean's, June 19, 2006, 16.

${ }^{192}$ Colin Freeze, "Khawaja trial witness recounts his radicalization," The Globe and Mail, June 23, 2008.
} 
in Pakistan, the United Kingdom and Canada (Ottawa). ${ }^{193}$ The capture in Morocco, in 2004, of terror suspect Nouredine Nfia offered additional clues on terrorist sleeper cells set up for attacks in the UK, France, Italy, Belgium and Canada. Mr. Nfia's statements on terror agents in Ottawa and Montreal was yet another call to arms for Canadian intelligence and security agencies, since it came shortly after the Madrid attacks of March 2004 , for which his group was initially blamed (until al-Qaeda claimed responsibility). ${ }^{194}$

Canadian counterterrorism authorities are said to have dismantled in 2005 an Algerian terrorist cell in Toronto, which "consisted of four Algerian refugee claimants who had lived in Canada for as long as six years and were alleged members of a radical Islamic terror faction called the Salafist Group for Call and Combat." ${ }^{\text {195 }}$ A 2005 Integrated Threat Assessment Centre (ITAC) report emphasized, once again, that Islamic extremism was the pre-eminent threat to North American homelands in the post-9/11 era: several planned terrorist incidents by al-Qaeda and other similar organizations with external roots were foiled since September 11, 2001, in both Canada and the United States, and the two countries remained likely targets for future terrorist actions. ${ }^{196}$

The security-related concerns, potential vulnerabilities and broad measures initiated by Canada in relation to the new threat environment, listed in the current subsection, helped provide evidence for an indeterminate security environment that renders Michael C. Desch's distinction between internal and external threats largely inapplicable to this

\footnotetext{
${ }^{193}$ Capt. (N) Peter Avis and Iain Grant, "Canadian Maritime Security and the Culture of Prevention," 56.

${ }^{194}$ Andrew Duffy, "Canada has sleeper cells: Moroccan terrorist," Ottawa Citizen, July 14, 2005.

${ }^{195}$ Stewart Bell, "CSIS breaks up terror cell," National Post, November 3, 2005.

196 ***, Islamic Extremism: Threats to North America (2005), cited in Stewart Bell, "Terrorism Threat Unabated," National Post, September 29, 2005.
} 
national context. The next subsection will detail responses to the post-9/11 security environment, as well as the perceived need to counteract the new dangers to national security, which provide further evidence for this threat assessment.

\section{III.3.d. A "fire-proof house" no more}

In military terms, Canada reacted very quickly and positively to the idea of joining the international coalition meant to bring the perpetrators of the $9 / 11$ attacks to justice. Among others, it deployed, as early as October 2001, several ships (HMCS Charlottetown, HMCS Iroquois and HMCS Preserver) in the Arabian Sea as part of Operation Apollo. In February 2002 the first major contingent of Canadian troops (850 soldiers - the $3^{\text {rd }}$ Battalion of the Princess Patricia's Canadian Light Infantry Battle Group) was sent to Afghanistan as part of US-led Operation Enduring Freedom, after several dozen JTF2 (special operations) soldiers were said to had already taken part in reconnaissance, surveillance and combat missions (being deployed in the country as early as two-three months after 9/11).

Almost 3,000 Canadian Forces men and women were involved in those early operations, a decision that indicates the degree to which the new situation was perceived as a landmark event in an amorphous post-Cold War era. "We're not a country that lives in splendid isolation," Minister of Foreign Affairs Peter MacKay would say in an August 
2006 interview: events around the world "affect us directly and sometimes we have to go to these faraway places and respond directly."

Gen. Rick Hillier argued that, while prior to 9/11 Canada intervened militarily in various regions of the world mostly for humanitarian reasons (e.g., in the 1990s), the international context has changed dramatically since the terrorist attacks on the United States. With it the place of Canada on the global stage and the role of Canadian Forces in the new strategic environment has changed as well: "[s]ince Sept. 11, we deploy men and women around the world to protect Canadian interests. We know that if we don't bring stability to places like Afghanistan, they will bring instability to Canada." ${ }^{198}$ In what has been seen by some as unnecessary, or even inappropriate, dabbling in policy matters (normally the job of civilians), Gen. Hillier offered the Canadian public his own assessment of why Canada needs to intervene in places like Afghanistan and a crude, yet powerful, picture of the nature of the Canadian Forces' intervention in such theatres of operations.

The enemy forces, Gen. Hillier said, are "detestable murderers and scumbags," who "detest our freedoms, they detest our society, they detest our liberties;" Canadian troops are, therefore, in Afghanistan to kill or capture those people before they will be successful in their "attempts to strike here in Canada."199 In 2005-2006 only, several attacks on Canadian troops in Afghanistan, that left dozens of soldiers dead, and the

\footnotetext{
${ }^{197}$ Interview with Peter MacKay, by Kenneth Whyte, "We're not a country that lives in splendid isolation," Maclean's, August 7, 2006, 13.

${ }^{198}$ Interview with Lt.-Gen. Rick Hillier, by John Geddes, "If we don't bring stability to places like Afghanistan, they will bring instability to Canada'," Maclean's, April 11, 2005.

${ }^{199}$ Stephanie Rubec, “"We can't let up' on terror," Edmonton Sun, July 15, 2005.
} 
kidnapping of two Canadian NGO workers, James Loney and Harmeet Singh Sooden, in Iraq served to underscore the violent realities Canada has to deal with in its foreign operations.

Canadian authorities acknowledged, however, their limited ability in predicting or counteracting specific terrorist incidents that may occur on domestic soil. It is absurd to think that attacks will not happen in Canada, Robert Wright, Canadian Security Advisor to the Prime Minister and Associate Secretary to the Cabinet, pointed out: Canada should therefore actively protect its interests at home and abroad and, furthermore, should insure that it is not itself a base for terrorist threats directed at the United States. ${ }^{200}$

One of the challenges with the latter is that Canada shares with the United States the world's longest non-militarized border and one of the busiest in the world in terms of commerce. Increasingly, the official discourse in both Ottawa and Washington, D.C., is shaped along the lines of the inevitability of new terrorist attacks upon these countries in the short and medium run: "not if, but when." To fight that undesirable scenario, Canada and the United States have initiated, post-9/11, a series of bilateral and multilateral mechanisms, such as the Smart Border Declaration of December 2001, whose aim is to protect the free flow of people and goods across the two countries' borders, but also to prevent further terrorist incidents. "The terrorist attacks on the United States in

\footnotetext{
${ }^{200}$ Robert Wright, "The New Security Environment in Canada: Are We Getting It Right?," keynote address delivered to the CASIS 2004 International Conference Peace, Order and Public Safety Post 9/11: Are We Getting It Right?, organized by the Canadian Association for Security and Intelligence Studies, Ottawa, October 14, 2004.
} 
September 2001 prompted us to take a much closer look at North American security," explained Minister of National Defence Bill Graham. ${ }^{201}$

Implied in Mr. Graham's comments was the need for much closer cooperation with the United States on a wide array of security and defence issues. As mentioned previously in this thesis, it was a changed threat environment that gave impetus to closer and more dynamic relations between the two countries in this area in the years following 9/11. While genuinely responding to what were perceived as immediate threats to its national security, Canada also took appropriate measures to protect the security interests of the United States and to maintain or advance strong links to its mighty neighbour. However, that cooperation does not occur automatically and, occasionally, domestic political considerations may even prevent joint Canadian-US projects from taking off, e.g., Canadian participation in the United States' National Missile Defense (NMD) program. A more detailed analysis of this issue will be provided in next chapters of this thesis.

Yet, while not participating in the NMD program, Ottawa repeatedly announced after 9/11 its willingness to defend North America from threats and took concrete measures to protect the security of both Canada and the United States. Canada quickly realized after September 11, 2001, that it was its obligation under the terms of a de facto new international environment, as an important player on the world stage and as a friendly neighbour of the USA, to protect both its interests and the interests of the United States in what was meant to be a long war against terrorist and insurgent forces.

\footnotetext{
201 ***, "Canada and United States Commit to Renewed Defence Cooperation," Canada NewsWire, November 29, 2004.
} 
Canada, along with most other key actors in the world, realized that the new stage in international affairs was defined not only by the nature and intensity of threats (terrorism as a main threat today, Communism during the Cold War), but also by the United States' reaction to these security challenges. Ottawa quickly concluded that taking solid and consistent action on security issues was imperative in order to alleviate US concerns about Canada as a possible source of terrorism and, thus, maintain healthy and indispensable economic and political links across the Canada-US border. As a consequence of this new context, Canada engaged swiftly and positively in setting up and revamping institutions and policies to address the new threat environment and the new terms of its relationship with the United States. The degree to which it altered its institutional and policy-making frameworks to deal with the new security context underscores, once again, the large extent of changes in the global environment that prompted these reactions.

To the seriousness of the terrorist threat many Canadian officials and analysts quickly added the gravity of the proliferation of weapons of mass destruction. Canadian officials also underscored the need to intervene in failed and failing states, such as Afghanistan, to provide them with much-needed order and stability. This position was consistent throughout the 2001-2006 period in Canada, despite the fact that the country was led by two distinct political forces: the Liberal Party of Canada (until February 2006) and the Conservative Party. It reflects Canada's concerns with a security context that is seen as hazardous, difficult to define and in a continuous state of flux. At the domestic level, the 
Canadian society has entered an era in which threats are perceived as real and deadly - a significant departure from early post-Cold War years (even if Canada was military active in the 1990s). At the international level, the Government has made instrumental use of an altered world order to advance its strategic goals, alongside counteraction measures. The next section will unveil similar patterns in the context of this dissertation's second case study, Romania.

The current analysis of threat levels and security-related responses in post-9/11 Canada has provided evidence for one of the main hypotheses of this dissertation: that the configuration of threats as they relate to this national context - and, by extension, to Western countries in general - during the period covered by this study cannot be determined along the lines of internal/external threat levels. Governments approached the post-9/11 era as a return to a period of security turbulence, of transnational challenges brought upon by the combination of threats such as international terrorism, WMD proliferation and failed and failing states. Canada's responses to the new security context substantiate these findings: government resources were directed during the 2001-2006 period toward both external missions and homeland security projects. The next section will investigate similar developments and will reach similar conclusions in the context of the second case study of this thesis, Romania. 


\section{III.4. Case study: Romania}

\section{III.4.a. Introductory remarks}

The end of the Cold War and the fall of the Soviet Union offered Romania the chance to transform its domestic processes radically and to reposition itself on the international stage. The historical changes of 1989-1991 constituted for this Warsaw Pact country the springboard for its reintegration into Euro-Atlantic economic, political and security structures. In the words of many Romanians, the new geo-political context allowed Romania to "return to its European destiny." However, the new world order brought novel challenges and, with them, the need for fresh re-conceptualizations of state responses. Romanian elites realized that the former bipolar standoff was replaced by a myriad of threats, ranging from transnational organized crime to terrorism and weapons of mass destruction to global environmental degradation and pandemics. ${ }^{202}$

The government was generally overwhelmed during the early post-Cold War era by the wide array of potential threats to be addressed, in a context in which the country struggled with a myriad of challenges related to its transition to liberal democracy and market economy. It is only understandable that, in the words of Minister of National Defence Victor Babiuc, "participation in security arrangements which address these new threats [was] a main foreign policy objective in the Central and Eastern European nations

\footnotetext{
${ }^{202}$ No serious attention was given and no significant preparations were put in place in this latter area until an outbreak of H5N1 avian influenza occurred in south-east Romania in late 2005.
} 
confronted with complex problems of transition."203 While several options were assessed in the early 1990s (including neutrality and the creation of regional security arrangements), Central and Eastern European countries such as Romania opted forcefully for integration into Western organizations such as NATO and the European Union. These institutions were seen in the former Warsaw Pact countries as not only being able to meet the latter's security needs in a changing international environment, but also offering the models and means for Central and Eastern Europe's transformation into a prosperous economic area.

These countries' geo-political repositioning was not merely - as some analysts saw it at the time - "euphoria resulting from the revolutions themselves [and] optimism about a 'Return to Europe' by joining NATO and [...] the European Union."204 Symbolism did play an important role in Central and Eastern European countries' vigorous attempts to leave the former Soviet arrangements behind: countries such as Romania perceived their Communist experience as an unnatural departure from their European vocation. But these governments were equally concerned about the future of Europe, their role in the new international configuration and their ability to provide political goods (including security) to their citizens. Joining organizations that could help them achieve ambitious objectives was a logical step for countries that had longed for decades to escape the structural constraints of an unfair world order.

${ }^{203}$ Victor Babiuc, "Reform of the Romanian Armed Forces: Modernization and Interoperability," in Romania and Euro-Atlantic Integration, ed. Kurt W. Treptow and Mihail E. Ionescu (Portland: The Center for Romanian Studies, 1999), 120-121.

204 Jeffrey Simon, "East Bloc Military Must Be Civilian Led," Aviation Week \& Space Technology, vol. 143, no. 10 (September 4, 1995), 10. 
While the Russian threat was still perceived as real and other security concerns were present as well, Central and Eastern European countries saw the North Atlantic Treaty Organization as much more than a defence alliance. At a time of great transformation and in a context of limited resources, countries such as Romania, "sure of their national orientation, but without a clear idea of how to achieve it, first looked at NATO as an organization which would come and solve all their problems." ${ }^{, 205}$ At the same time, both Western organizations such as NATO, on the one hand, and Central and Eastern European countries, on the other, had to redefine, in the post-Cold War context, their security and defence policies and responses to the new global environment. ${ }^{206}$

Although countries such as Romania implemented a large set of measures to facilitate their integration into Western organizations (primarily, NATO and the EU), the latter and their member states also had to reposition themselves in a fundamentally different international configuration. The European Union, for instance, would establish and consolidate in the early 2000s a European Security and Defence Policy (ESDP), which would be used in an attempt to coordinate common EU responses to the new world order, particularly in the post-9/11 era. ${ }^{207}$

\footnotetext{
${ }^{205}$ Chris Donnelly, "Defence Transformation in the New Democracies," NATO Review, no. 6 (November 1996), 20.

${ }^{206}$ Interviews with Alba Lamberti, EU Liaison Manager, and Dan Vexler, Research Manager, International Crisis Group, by the author, Brussels, Belgium, April 8, 2005.

${ }^{207}$ Interview with Dr. Kyriakos Revelas, Principal Administrator, Security Policy Unit, DG External

Relations, European Commission, by the author, Brussels, Belgium, April 7, 2005
} 
III.4.b. The Romanian perspective on the new security environment

Throughout the 1990s, but particularly during the first half of the current decade, Romania implemented measures that allowed it to join NATO in 2004; it joined the European Union as well, in 2007, along with its southern neighbour, Bulgaria. While these key foreign policy objectives were achieved, Romanian officials were well aware that the same international context that allowed their country to leave Communism and the Soviet repression behind brought with it new risks and vulnerabilities. In this situation, as Chief of the Department for Euro-Atlantic Integration in the Ministry of National Defence (MApN) George Cristian Maior emphasized, the transformation of the country's security and defence policies and institutions "is not necessarily meant to accommodate the requirements of NATO accession; it emerges out of domestic needs, since $[\ldots]$ we live in a changed world, in a fluctuating security environment." ${ }^{208} \mathrm{MApN}$ officials repeatedly underlined, especially in the post-9/11 context, the necessity of identifying proper responses to a more diverse array of security concerns, often through an independent (rather than multinational) assessment process.

Chief of the General Staff (CGS) Gen. Mihail Popescu underscored this idea a few years after Romania had already been invited to join NATO. It was not NATO that drove the transformation of the national armed forces during the last decade, he said, although Euro-Atlantic integration, de facto and de jure, was a fundamental objective of post-Cold

\footnotetext{
${ }^{208}$ George Cristian Maior, "Nu intram in NATO pentru a beneficia de securitate, ci pentru a participa la crearea securitatii," Gandirea militara romaneasca, no. 1/2002, 175.
} 
War Romania: “The profound transformation of the Romanian military establishment is based primarily on the very complex requirements of defending the country today and of establishing armed forces that can [...] engage flexibly in creating global security."209 Assessments of the new threat environment following the end of the Cold War and post$9 / 11$, conducted by Romanian experts, indicated the need to react independently to the new international security environment, but also the country's necessary integration into international security structures, among which NATO was given prominence. ${ }^{210}$ (Accession to organizations such as NATO and the European Union was also used by Eastern European countries such as Romania as a springboard for their economic and political rebirth after the end of the Cold War, yet in-depth analysis of that process is beyond the scope of this thesis).

As Romanian officials pointed out, threat assessments were not simply borrowed from Western organizations or governments and formalized in policy documents, so that Romania was perceived to be "more Western." Its transformation in the fields of security and defence, although often based on Western models, was driven by domestic concerns and national objectives. Romania promoted its key national interests through adaptation to the new international environment - as countries generally do - as it saw fit. One of the ways of promoting its interests has been through NATO accession (based on shared values and goals); however, Romania has not always implemented unreservedly the NATO acquis and the process of adaptation to the new world order has often gone both

\footnotetext{
${ }^{209}$ Gen. Mihail Popescu, "Prefacerea organismului military romanesc corespunde nevoilor de aparare ale Romaniei," Gandirea militara romaneasca, no. 1/2003, 11.

${ }^{210}$ Interview with Stefan Tinca, Security and Defence Expert, Mission of Romania to the European Union, by the author, Brussels, Belgium, April 7, 2005
} 
ways. NATO accession countries and its new member states have undoubtedly transformed the Alliance as well, particularly in the post-9/11 era.

Prior to September 11, 2001, Romania listed among its top security concerns disintegrative phenomena - including state failure - in its near abroad (inter alia, the break up of the Soviet Union, Yugoslavia, Czechoslovakia and, de facto, the Republic of Moldova) and their possible spill-over effects on Romania; post-9/11, terrorism, WMD proliferation and state failure became key issues on the Romanian government's agenda. Romanian authorities emphasized, in domestic debates and in various international fora, the threat posed by "the globalization of vulnerabilities, $[\ldots]$ threats $[\ldots]$ and aggressive actions, materialized through the activity of not only state actors, but also groups and individuals, organized in international networks that escape control, that can be present and strike anywhere in the world." 211 Also emphasized repeatedly would be the need to fight fundamentalist groups perpetrating violence against innocent civilians, which became, post-9/11, a new item on the country's list of security priorities. The regional component of Romania's security concerns did not disappear, however; on the contrary, regional risks and vulnerabilities, as well as occasional interethnic tensions at the domestic level, re-emerged as significant security anxieties, since they could become interlinked with the main threats that define the current global environment.

Similar to the international system as a whole, Romania's immediate neighbourhood and the broader region in which the country is positioned has changed dramatically since the

211 Gheorghe Fulga, "Romania si mediul regional de securitate," http://www.sie.ro, 2005 (accessed September 10, 2005). 
fall of the Iron Curtain. Past or present conflicts in the separatist region of Transdniestria (the Republic of Moldova) ${ }^{212}$ and in the former Yugoslav space (Kosovo, among others), but also in further away territories such as South Osetia and Abhazia (Georgia), NagornoKarabach (Azerbaijan), Chechnya (Russia) and Kurdistan (covering parts of Turkey, Iraq, Iran, Armenia and Syria), have heightened Romania's sense of insecurity in a volatile part of the world. Most of these conflicts emerged following the disintegration of the Soviet Union and, according to Gheorghe Fulga, Director of Romania's Foreign Intelligence Service (SIE), "they have affected the political and economic development of countries in the region, contributing to more radical political life and increased instability, an ideal environment for the proliferation of phenomena such as organized crime and terrorism." ${ }^{213}$ South East Europe and the larger Black Sea region are, in Romanian authorities' view, areas in which inter-linkages between various categories of threats become visible and pose a significant danger to countries' security and stability.

Even pre-9/11 analyses by Romanian officials and independent experts indicated the new nature of international threats, their close interrelatedness and the need for states' joint efforts in counteracting these novel challenges. Post-9/11, their attention has been drawn

\footnotetext{
${ }^{212}$ Transdniestria, a narrow strip of land at the Republic of Moldova's eastern border, is of particular concern to Romania, given not only the large proportion of Romanian citizens living in Moldova, but also the separatist region's proximity to Romania. The breakaway republic of Transdnistria is widely seen as a very convenient transit spot for smuggling rings and possibly terrorist networks and as a genuine threat to world security, as the territory is used as a reliable source of weapons, possibly including WMD. In the post-9/11 context, Transdnistria has increasingly received the undesirable reputation of a rogue quasi-state, although Western intervention in its domestic affairs is virtually impossible for now, given the presence on its territory of Russia's 14th Army (the former Soviet 14th Army). European countries such as Romania engage actively in presenting Transdniestria as a fine illustration of the "negative effects of insufficient state control over weaponry, munitions and materials necessary for manufacturing weapons of mass destruction, which can be easily acquired by groups or states that sponsor or perpetrate terrorism" (***, "Interviu acordat de directorul SIE, dr. Gheorghe Fulga, reporterului cotidianului ZIUA, Radu Tudor, la 26 noiembrie 2004," http://www.sie.ro, November 26, 2004 (accessed July 2, 2005)).

${ }^{213}$ Gheorghe Fulga, "Climatul de securitate in regiunea Marii Negre extinse dupa 11 septembrie 2001," http://www.sie.ro, 2005 (accessed June 26, 2005).
} 
increasingly to unconventional, asymmetrical threats, such as terrorism and weapons of mass destruction; conventional threats (e.g., aggressive military action by neighbouring countries) have hardly received mention in the country's post-9/11 security assessments. Many Romanian experts share, in this new international environment, Col. Nicolae Dohotariu's view that "the main characteristic of $21^{\text {st }}$ century's confrontations will be asymmetry; and the rise of terrorism - through its various forms of manifestation, potential targets and possible effects - will be the key threat to regional and global security." ${ }^{214}$ The number of analysts and officials that still place conventional military threats at the top of their assessments and policy agendas has decreased considerably.

Terrorism and the proliferation of weapons of mass destruction are superimposed, however, on other, equally serious, threats that Romanian officials consider important tackling: organized crime, illegal migration and interethnic conflicts. What they often emphasize is that terrorism can be more lethal and can have a more striking impact on a country, yet all these threats are inter-related and even present a high degree of adaptation to various national and regional contexts. "We can speak, with certainty, of 'the most explosive' combination: terrorist organizations, sponsoring states, organized crime and weapons of mass destruction," SIE Director Gheorghe Fulga stated in a 2005 material. ${ }^{215}$ To back up their threat assessments, organizations such as the Romanian Intelligence Service (SRI) point to a growing number of organized crime cells and terrorist groups that operate in Romania's immediate neighbourhood, including on Romanian territory inter alia, they were alleged to be involved in illegal transactions with components of

\footnotetext{
$214 * * *$, Confruntarile asimetrice," Gandirea militara romaneasca, no. 4/2002, 90 .

${ }^{215}$ Gheorghe Fulga, "Combaterea terorismului international si a criminalitatii organizate transfrontaliere," http://www.sie.ro, 2005 (accessed June 26, 2005).
} 
nuclear and biological weapons, originating in Ukraine and other former Soviet republics. $^{216}$

Romanian officials have repeatedly emphasized in recent years that their assessments of threats to national security are similar to assessments done by Romania's allies, notably the United States and the United Kingdom. While national specificity is related to assessments of regional security environments, top international threats are virtually identical in documents prepared by Western countries, Romania included. The extent to which the new international security context was used instrumentally by Romania to advance its objective of stronger links to its Euro-Atlantic partners will be investigated briefly later in this chapter and in next chapters of this thesis.

Romania's Supreme Council of National Defence (CSAT) listed, in early 2005, five key components of the country's national security strategy in the post-9/11 context. According to CSAT, the main threat to national security in the new global environment is international terrorism, followed by the proliferation of weapons of mass destruction and "totalitarian regimes that sponsor terrorism." The fourth and fifth places are held by crisis situations in Romania's strategic neighbourhood ("frozen conflicts or situations of political instability") and, at the domestic level, poor governance (associated with relatively high levels of corruption among state officials and public servants). ${ }^{217}$

\footnotetext{
${ }^{216}$ Radu Tudor, "Brigada Antiterorista din Romania isi extinde cooperarea in lupta impotriva terorismului," http://www.sri.ro, January 2002 (accessed June 26, 2005).

$217 * * *$, "Comunicat de presa," http://www.presidency.ro, February 28, 2005 (accessed February 28, 2005).
} 
This threat assessment indicates the extent to which the post-9/11 strategic environment has influenced the positions of governments around the world on security issues; most countries have also used the new context to reposition themselves in the international arena. According to a SIE analysis, the events of September 11, 2001, have imposed "a shift in a majority of states' views on this scourge, no matter if they have been confronted or not with terrorist incidents on their national territories. ${ }^{218}$ It is in this context that Romania witnessed a paradigm shift in the way its institutions and experts (military and civilian) approached the new security environment in recent years.

As years passed following the events of 9/11, Romanian threat assessments and security analyses have moved further away, in a rapid and decisive manner, from traditional risks to national security and conventional response measures. They acknowledged the novel nature of conceptualizing and "doing" security in the post-Cold War and especially the post-9/11 period - a context in which terrorism has gained unexpectedly new and infamous connotations. Civilian and military officials pointed out that with the recent terrorist incidents in Western countries, "perceived as direct attacks on universal human values, we witness the beginning of a new type of terrorist actions, much more dangerous, as they are perpetrated by an enemy that is ever more elusive, bloodier and scrupleless." ${ }^{219}$ The 2005 London attacks in particular have further contributed to the realization among Romanian officials and other experts that the world has entered a new,

$218 * * *$, "Combaterea terorismului international in acceptiunea SIE," http://www.sie.ro, 2005 (accessed June 26, 2005).

${ }^{219}$ Col. Ion Coscodaru, "Terorismul: Implicatii asupra actiunilor militare," Gandirea militara romaneasca, no. 6/2001, 26. 
radically different, international security environment as compared with the first decade following the end of the Cold War.

The terrorist incidents of September 11, 2001, were perceived, in Romania and elsewhere, as a historical landmark, separating the twentieth century from the twenty-first century, after a decade of transition from the old to the new world order. As Romanian authorities put is, "[the] events of 11 September 2001 inexorably changed the world. They etched into the psyches of governments and people the need for committed alliances to stand together in a common cause" - the fight against international terrorism and related threats. ${ }^{220}$ They shattered the illusion that the world had entered an era of peace and security, in which significant military confrontations and violent conflicts had largely been eliminated, at least in the West.

In an attempt to clarify the rationale behind domestic institutional and policy changes, but also to send Washington a signal of Romania's intentions to "stay the course" in the USled "war on terror," President Traian Basescu pointed out in 2005 that "September 11, 2001, has meant a repositioning of governments, states and citizens vis-à-vis imminent dangers and real dangers, which have materialized forcefully since that moment."221 The concepts of "terrorism," "proliferation of weapons of mass destruction" and "failed and failing states" have become in the new era as commonly encountered in Romanian debates on security issues as "atomic diplomacy," "containment" or "spheres of influence" were in the West during the Cold War.

\footnotetext{
${ }^{220}$ Government of Romania, Romania on Its Way to NATO (Bucharest: Government of Romania, 2002), 185.

221 ***, "Traian Basescu propane internationalizarea Marii Negre," ZIUA, June 24, 2005.
} 
III.4.c. Post-9/11 security concerns in Romania

Although several recent assessments by the SRI Centre for Counterterrorist Operative Coordination indicate that, during the 2001-2006 period, the threat level for terrorist attacks on Romanian territory was low to moderate, terrorist attacks in Europe and "recent Jihadist statements by leaders of international terrorist organizations, present the potential of raising the threat level internationally, with clear consequences for Romania's national security."222 Romanian officials repeatedly underlined the transnational nature of the new terrorist threat: while originating from abroad in the vast majority of cases, terrorism tends to affect today Western countries at the domestic level, even those that have not yet experienced terrorist incidents on their national territory. A domino effect in terms of threat assessments and overall societal responses can be noticed throughout the West every time one or several countries are targeted by terrorist organizations.

While Romania has experienced very few terrorist incidents on its territory (about a dozen minor ones since the early 1970 s), there is fear today, among officials and other experts, that things may change for the worse. No terrorist incident has occurred targeting Romanian institutions or Romanian nationals specifically; most have been directed to foreign interests on Romanian territory. Among the most notable incidents are: the 19721973 attempts by the Black September terrorist organization to storm the Embassy of

$222 * * *$, "Centrul de Coordonare Operativa Antiterorista. Informare de presa. Evaluare pe trimestrul I/2004," http://www.sri.ro/, 2004 (accessed December 7, 2004). 
Israel in Bucharest; the 1985 car bombing on the University of Bucharest campus, organized by the Muslim Brotherhood and targeting Syrian nationals; the 1991 attempt (in Bucharest) by Sikh militants to assassinate Julio Ribeiro, the Indian Ambassador to Romania; and the 2005 attempted mail-bombing of Italian Catholic congregation "Surorile Providentei" (in north-western Romania) by a suspected Italian terrorist called by the media "Unabomber $2 . "$

However, with Romanian troops operating in Afghanistan and Iraq, and several United States military bases on Romanian territory (at the Black Sea), many experts estimated that attacks against Romanian targets were simply a matter of time. They argued that the kidnapping of three Romanian journalists in Iraq in 2005 - later recovered by special operations forces (SOF) - and attacks on Romanian troops in Afghanistan and Iraq in 2005-2006 (which left several soldiers dead and others wounded) were the beginning of a worrying trend. Romanian authorities arrested in May 2005 two individuals - Omar Hayssam, a Syrian citizen, and Mohammad Munaf, an Iraqi citizen - and charged them with masterminding the Romanian journalists' kidnapping.

The Romanian Intelligence Service estimated that at least ten terrorist organizations operated on Romanian territory and in the country's immediate neighbourhood shortly after 9/11: Muslim Brotherhood-derived organizations (Egypt), Hamas (Palestine), Hezbollah (Lebanon), the Party of Islamic Liberty (Uzbekistan), the Palestine Liberation Front (based in several Middle Eastern countries), Abu Nidal (Iraq), Kongra-Gel - former PKK (Kurdistan), Grey Wolves-related organizations (Turkey), the Revolutionary 
People's Liberation Party/Front or DHKP/C (Turkey) and other organizations linked to al-Qaeda. ${ }^{223}$

Col. Mihail Ciuperceanu, General Director for Military Intelligence at MApN, pointed out that these terrorist organizations had operatives or interests on Romanian territory: "they are involved in organized crime, drug trafficking, human trafficking and illegal migration. [But these] terrorist cells can act as intermediary for possible attacks on Romania, via Transdniestria or originating directly from the strategic Islamic region.,224 During the 1995-2005 period, close to 1,000 foreign citizens, the vast majority of them of Muslim background, were deported from Romania on security-related charges. ${ }^{225} \mathrm{SIE}$ Director Gheorghe Fulga added, in a dramatic manner, that "Romania is stuck in a cobweb of terrorist groups that can anytime unleash acts of terror such as the ones on September 11, 2001, in the United States, ${ }^{, 226}$ which pointed equally to domestic and external threats affecting the country's security. His statement and other similar positions by Romanian officials and independent experts underscore the complex nature of the post-9/11 security environment, particularly the interconnectedness of internal and external threat factors.

As exemplification of its new view of the changing international security environment, the Romanian government initiated, in February 2002, a process involving 23 institutions to set up a National Strategy for the Prevention and Counteraction of Terrorism.

\footnotetext{
${ }^{223}$ Radu Tudor, "Brigada Antiterorista din Romania isi extinde cooperarea in lupta impotriva terorismului." ${ }^{224}$ Mihai Diac, "Pe teritoriul Romaniei sunt prezente zece grupari teroriste," Gandul, May 27, 2005.

${ }^{225}$ Radu Tudor, "Interventia, esecul prevenirii terorismului," Jurnalul national, October 8, 2005.

${ }^{226}$ Adrian Artene, "Romania, plasata pe axa de actiune a unor organizatii teroriste," Libertatea, January 24, 2005.
} 
According to a decision made by the Supreme Council of National Defence in October 2001, the Romanian Intelligence Service was given the authority to coordinate counterterrorism-related measures. The National Strategy for the Prevention and Counteraction of Terrorism identified terrorism as a key threat to national security and, for the first time in the country's history, a legal document elaborated on the nature of terrorism, its varieties and possible targets. ${ }^{227}$ A specialized institution (UM 0962), part of Romania's Ministry of Interior, was added to the national counterterrorism system. The Government thus responded to "a new security environment, one characterized by the globalization of processes and activities [...] so that it can meet its challenges, according to $[\ldots]$ the fundamental interests of the Romanian state," SRI Director Alexandru Radu Timofte said in January 2003.

Immediately after the beginning of the US-led military intervention in Iraq in 2003 and in the context of the Afghan mission, the Romanian Government concluded that the threat level increased domestically and took measures to protect its citizens and locations of strategic importance from possible terrorist attacks. Among others, border guards were put on high alert; additional security measures were implemented at nuclear facilities, airports, oil refineries and industrial sites working with chemical materials; additional guards were assigned to water processing plants; and more emphasis was placed on the training of crisis intervention teams, some of them specialized in biological/chemical terrorism response.

$227 * * *$, "Proiectul strategiei nationale de prevenire si combatere a terorismului - aproape de finalizare," http://www.sri.ro/, February 7, 2002 (accessed December 7, 2004). 
One year later, after the attacks on the Madrid transit system by al-Qaeda-related terrorists, the Romanian government intensified its emergency preparedness measures, based on an assessment of a heightened threat to the country's security at home and Romania's interests abroad, and it toughened its rhetoric on the need for additional efforts in the war against international terrorism. Minister of National Defence Ioan Mircea Pascu argued that "the fight against terrorism goes beyond politics and nationality. It is the fight of those that want to live against those that want to kill, to destroy life."228 Even more determined positions from Romanian officials, the media and regular citizens against terrorism were expressed after the London attacks of 2005 , in which - as in previous incidents in the USA and Spain - Romanian nationals were killed.

While the Romanian government condemned the attacks in the strongest terms, a terrorist group named The Secret Organization of al-Qaeda in Europe once again warned all states with troops in Afghanistan and Iraq that they would share the fate of the UK. Fearing attacks on the Bucharest transit system, the Romanian government employed gendarmerie teams in key underground stations. The London attacks had a noticeable impact on the Romanian society: Romanian citizens died in those incidents, they occurred just a year after the Madrid attacks and another key ally of Romania's was targeted by international terrorism. "The London terrorist attacks demonstrate, once again," security analyst Radu Tudor argued, "what we already knew: that Europe is at war with terrorism."229 In light of such assessments, the Romanian government increased constantly during the 2001-2006 period the funding allocated to intelligence and special

\footnotetext{
${ }^{228}$ Gen. Mihail Floca, "Europa sub teroare," Observatorul militar, no. 11 (March 17-23, 2004).

${ }^{229}$ Radu Tudor, "Europa in razboi," ZIUA, July 8, 2005.
} 
services such as the Romanian Intelligence Service, the Protection and Guard Service (SPP) and the Special Telecommunications Service (STS). ${ }^{230}$

Despite significant efforts to address potential security threats at the domestic level - in both institutional and policy terms - there is little evidence to suggest that the country was threatened by terrorism from within during the 2001-2006 period. No terrorist incidents occurred in the country over the five-year period covered by this study and no publicly available information suggests that Romanian nationals were involved in terrorism-related activities abroad. The only significant incident during the 2001-2006 period occurred in June 2006, when counter-terrorism forces arrested a Romanian citizen converted to Islam, Florin Lesch (a.k.a. Ayhah Hassan Abger), allegedly attempting to detonate a home-made bomb in downtown Timisoara, Romania's fourth largest city and home of a sizable Muslim community. It is alleged he had links to Islamic fundamentalist operatives abroad, and his actions were meant to determine the Romanian Government to withdraw its troops from Iraq. ${ }^{231}$ Yet the very connection between developments in the international arena and events at home, as well as the transactional nature of the new security challenges, contribute strongly to the argument that the analytical distinction between external and internal threats is very difficult to sustain. Moreover, as Glen McGregor pointed out, in relation to the Canadian case, the lack of terrorist incidents over the period covered here "shows that either no attacks have been attempted or that the

${ }^{230}$ Gabriela Palade, "Serviciile speciale ne costa 338 milioane de euro," Evenimentul zilei, November 2, 2004.

${ }^{231}$ O. Marascu et al., "Arestarea teroristului-butelie," ZIUA, June 28, 2006. 
buckets of money spent on 'hardening' potential targets and bolstering intelligence are paying off.",232

Romanian intelligence agencies pointed out that foreign citizens were active in fundraising activities for international terrorist groups on Romanian territory, yet no charges were laid and no convictions made for such alleged offences. Nonetheless, numerous homeland security initiatives were motivated by fear of terrorist attacks; the lack of actual terrorist incidents did not constitute a guarantee of lower threat levels internally.

On the military side of the country's security and defence establishment, the Romanian armed forces were further modernized and reorganized, based on a professional (i.e., nonconscriptionary) model - a process begun in the early to mid-1990s, but given new impetus after 9/11. In October 2004, President Ion Iliescu presented, in a nutshell, the key desired characteristics of the Romanian military, which should become "leaner, more efficient and flexible, capable to respond to national security needs and, alongside allies, to engage in a variety of international missions, fighting the new threats to peace and security, especially terrorism and the proliferation of weapons of mass destruction. ${ }^{.233} \mathrm{In}$ response to the new security environment and the growing need for Romanian armed forces participating in campaigns against terrorist and insurgent groups on foreign territory, particular emphasis was placed on special operations units (inter alia, mountain troops), military intelligence and military police. Although the process of transformation

\footnotetext{
${ }^{232}$ Glen McGregor, "Judging terrorism's real threat to Canada."

233 ***, "Mesajul domnului Ion Iliescu, Presedintele Romaniei, cu prilejul Zilei Armatei Romaniei," http://www.presidency.ro, October 22, 2004 (accessed October 25, 2004).
} 
of the Romanian military was initiated in the early 1990s and was driven by both domestic and external factors (e.g., NATO), it was accelerated post-9/11, being given impetus by a novel threat environment.

During the 2001-2006 period, Romania adopted and implemented legislation freezing terrorist financing, it intensified intelligence sharing with its key allies (notably the United States and the United Kingdom) and it adapted all key policy instruments (such as its National Security Strategy) to the new security framework. It also actively promoted a mission expansion of the Bucharest-based Southeast European Cooperation Initiative (SECI) Center for Combating Trans-border Crime to include counterterrorist activities. ${ }^{234}$ All the measures and security concerns reviewed in the current subsection serve to underscore the extent to which Romanian authorities deemed it necessary to respond to what they perceived to be a radically changed threat environment and international configuration. The emphasis was both on external missions and on addressing potential security vulnerabilities at home; the next subsection will detail some of the most significant security and defence responses initiated by Romania between September 11, 2001, and September 11, 2006, with particular emphasis on the country's military engagements.

III.4.d. A "proactive" security and defence policy

At the international level, Romania offered, as early as January 2002, its support to set up the UN-mandated, NATO-led International Security Assistance Force (ISAF) in

${ }^{234}$ Government of Romania, Romania on its Way to NATO, 165. 
Afghanistan, acting as a de facto NATO member. In addition to its military contribution to ISAF, Romania provided from the early moments of the new "war on terror" assistance with over-flight rights for the immediate US military response to $9 / 11$ : Operation Enduring Freedom (OEF) in Afghanistan, meant to topple that country's Taliban regime and to capture or kill al-Qaeda terrorists. Romanian troops were deployed to Afghanistan as part of Operation Fingal (ISAF) based on a unanimous decision by the Romanian Parliament. An infantry battalion of 400 troops and a nuclear, biological, and chemical (NBC) warfare company of 70 troops were sent to Kandahar; Romania's military effort in Afghanistan would increase to around 600 troops as part of the NATOled International Security Assistance Force. Not only the troop numbers increased in the latter part of the 2001-2006 period covered by this study, but also their specializations (by 2005-2006, they included special operations forces, used in hunting down suspected terrorists and insurgents). In Iraq, Romania had at its peak, in 2005-2006, 730 personnel including 400 infantry, 100 military police and 150 de-miners - deployed as part of the US-led Multi-National Force - Iraq (MNF-I); by mid-2007, the numbers would be reduced to around 400 .

The post-9/11 threat environment presented Romania with an opportunity not only to prove that the country was willing to share the burden of responding forcefully to multifaceted international security challenges and that its armed forces were capable of taking part in complex multinational operations; but also to strengthen its relations with some of its key strategic partners, most notably the United States and the United Kingdom. As a concrete response to the new international threat environment, Romanian 
military units fought suspected terrorists and insurgents in Afghanistan - and, to a lesser extent, in Iraq, where Romanian armed forces acted primarily in a supporting role.

In Afghanistan, Romanian contingents operated alongside US, British and Canadian troops in the Afghan capital Kabul and in the country's second largest city, Kandahar. As a member of the North Atlantic Treaty Organization, Romania shared with its NATO allies both a similar vision of the current international security environment and a similar philosophy on the need to reduce the threat of terrorism and to spread democratic values to countries around the world. Although there is acknowledgement among Romanian experts that addressing world inequality or problems related to failed and failing states is no assurance of getting rid of terrorism or other asymmetrical threats, the Romanian government deemed necessary to pursue a proactive policy, alongside other Western nations, on foreign territory.

Romania expressed in recent years, along with allies such as the United States and the United Kingdom, its conviction that the threats to international security have to be addressed at their source. Senior Romanian officials at all levels of government have underscored the need for their country and for the international community at large to intervene militarily in other regions, if all other options have been exhausted, so that international security is not jeopardized by entities such as terrorist groups or rogue states. The breadth of all these changes serves to underscore the extent to which Romania acknowledged the rise of a new threat environment, whose chief threats (internally and externally) are significantly different from the ones preceding $9 / 11$. 
The paradigm shift from mainly reactive to preponderantly proactive security and defence policies occurred with the events of September 11, 2001. Four years later, in September 2005, President Traian Basescu told the United Nations General Assembly that "the protection against security threats must not be limited to measures taken at own borders; it must involve actions in the regions where these threats arise [...]. It is for these reasons that Romania has joined its partners and allies in the stabilization and reconstruction efforts in Iraq and Afghanistan. ${ }^{, 235}$ The national security priorities presented by the centre-right coalition that won the general parliamentary elections of 2004 (National Liberal Party-Democratic Party) emphasized as well the idea that Romania had responsibilities related not only to defence of its national territory and preventive diplomacy. It also had to engage in activities that promote proactively its interests abroad.

Romania's new policies built on documents issued by the previous centre-left government (Social Democratic Party-Romanian Humanist Party) in the areas of security and defence, such as the White Paper on Security and National Defence, the Military Strategy of Romania and the National Security Strategy of Romania, most of which were released following the terrorist incidents of September 11, 2001. According to President Traian Basescu, at that moment the world entered a new security environment in which democratic countries, such as Romania, are specifically targeted by religious fundamentalist organizations. The very nature of a democratic polity becomes, in

$235 * * *$, "Comunicat de presa," http://www.presidency.ro, September 15, 2005 (accessed September 20, 2005). 
terrorists' views, cause for retaliation, a feature that has to be eliminated by violent means, so that radical ideas prevail.

While stressing the fact that Romania stands by its democratic values and practices, Romanian officials along with President Basescu underscored the fact the country has an obligation to "stay where it is, alongside its allies, and to fight with all means at its disposal the scourge of terrorism."236 Yet Romanian military involvement in foreign theatres of operations (in Afghanistan and elsewhere) came at a cost. In addition to the financial burden of sending several thousand troops abroad for extended periods of time, Romania had to confront the reality of violent conflict: soldiers were occasionally killed and wounded in mission, which led to debates over the role of armed forces in society and the country's foreign military interventions.

With Romania's involvement in Afghanistan and Iraq, the debate also touched on the potential repercussions to homeland security, i.e., increased probability of terrorist attacks on Romanian territory as retaliation for Romanian armed forces' actions against terrorists and insurgents in the two countries. SIE Director Gheorghe Fulga presented in 2005 terrorism as a "major threat" to national security and linked possible attacks to Romania's war against international terrorism in Afghanistan, Iraq and Kosovo. ${ }^{237}$ President Traian Basescu announced that the heightened risk to domestic security would not deter Romania from maintaining armed forces in Afghanistan and Iraq "as long as necessary."

\footnotetext{
${ }^{236}$ A. M. B., "Romania, o tinta pentru teroristi, ca orice democratie," Gandul, July 13, 2005.

${ }^{237}$ Adrian Artene, "Romania, plasata pe axa de actiune a unor organizatii teroriste."
} 
While Hungary, Bulgaria, Ukraine or Poland, as countries in the same geographic region as Romania, reduced their military presence in the two theatres of operations or withdrew their troops altogether (mainly from Iraq) during the 2001-2006 period, Romania confirmed its decision to stay in Afghanistan and Iraq, along with other Western allies, for the long haul. This position was meant on the one hand to convey its determination in the face of an increasingly deadly and disruptive set of threats, and on the other hand to send a message to its key allies that it supported their military efforts overseas and hoped for improved relations.

President Ion Iliescu explained the avalanche of his country's post-9/11 reaction measures (at both the domestic and the international level) as a natural response in a new democracy where symbolism is important: "[w]e understood the brutal attacks of 11 September as attacks against all freedom-loving nations and felt compelled by human solidarity to offer not only compassion, but also our concrete support in the war against terrorism. ${ }^{238}$ Other officials emphasized as well the need for a multinational response to a global threat; but also the importance of countries such as Romania repositioning themselves in relation to a military superpower that had come under attack. Romanian officials also pointed to the new threat environment as offering Romania an opportunity to speed up processes of domestic reform in the areas of security and defence and facilitating closer synergy with its Western allies (something it had been longing for).

\footnotetext{
${ }^{238}$ Ion Iliescu, "Taking No Chances," Transitions On-Line, http://www.tol.cz, November 21, 2002 (accessed November 21, 2002).
} 
Stronger bilateral relations with the United States and the United Kingdom (among other European partners) were seen as important by Romanian policy makers and Romanian assistance in the new "war on terror" certainly helped strengthen those relations. It is important to underscore in this context, however, that it is the very threat environment that made possible a reconfiguration of bilateral relations and transnational security arrangements. The fact that Romania could pursue forcefully its key security interests in the new international environment only serves to emphasize the changing nature of the world rather than changing fundamental objectives of Romania on the international stage. Romanian officials are also quick to argue, as Prime Minister Adrian Nastase did in 2002, that the country's military involvement in Afghanistan "came not by conjecture, but from a firm commitment to promote security and cooperation in [its] region and worldwide. During the decade preceding $9 / 11,7,000$ Romanian soldiers participated in international missions to maintain peace and stability in Kuwait, Rwanda, Somalia, Angola, Albania, Bosnia and Kosovo."239

Following the events of September 11, 2001, Romania's military interventions in Afghanistan and Iraq and corresponding security-related domestic measures were supported by both government coalitions that led the country during the 2001-2006 period: Social Democratic Party-Romanian Humanist Party (until November 2004) and National Liberal Party-Democratic Party: Overall, at both the domestic and the international level, the Romanian society perceived the post-9/11 period as an era of dramatic security changes - officials and regular citizens became aware of potential

\footnotetext{
${ }^{239}$ Opening Remarks by Adrian Nastase, Prime Minister of Romania, at the summit The Spring of New Allies, organized by the North Atlantic Treaty Organization, March 25, 2002, Bucharest, Romania, cited in Government of Romania, Romania on its Way to NATO, 172-173.
} 
threats at home, the need to respond forcefully to a new threat environment, including militarily, and the opportunity the new context provided for improved bi-lateral and multilateral international relations.

The current section has offered arguments substantiating the claim that, from a Romanian perspective, the post-9/11 threat environment can be viewed as indeterminate; the assessment of security configurations as a function of the location and the intensity of threats does not fit closely any of the four arrangements in Michael C. Desch's model. Similar to the rest of Western countries, Romania approached post-9/11 external threat levels as high and reacted appropriately, alongside its international partners. Nearly identical findings in the two national contexts analyzed in depth in the context of this thesis (Canada and Romania) suggest that similar conclusions can be extended to other Western countries as well. The Romanian Government reacted to the events of September 11, 2001, along virtually identical lines compared to other Western counterparts: it reassessed its stance on security and defence matters, re-arranged the hierarchy of threats to national security and initiated a vast array of measures (with resources being dedicated to both external missions and domestic security projects). The following chapter will analyze such responses in detail in both cases (Canada and Romania), by looking specifically at a predefined set of measures - intermediate variables in the context of this thesis. 
The current chapter has provided an assessment of the post-9/11 threat environment - it has offered both a general analysis of the international security context following the terrorist incidents of September 11, 2001, and an overview of the perception of threats in two national contexts (Canada and Romania). The latter undertaking was meant not only to shed light on the new security environment in post-9/11 Canada and Romania - thus facilitating understanding of security and defence issues in the two countries - but also to provide evidence for the idea of an indeterminate threat environment, as it relates to Western countries.

This chapter has argued that the events of September 11, 2001, have dramatically altered the way security is conceptualized in the West and response measures are designed and implemented by governments, individually and collectively. It has also made a case for transnational threats for countries such as Canada and Romania, and implicitly for Western polities in general - security challenges that are difficult to quantify and categorize, particularly along the lines proposed by Michael C. Desch, external and internal threats. The analysis of the post-9/11 threat environment (the independent variable in the context of this thesis) and Western countries' new strategic priorities has revealed an unexpected finding: countries (other than the United States) react to what they perceive are genuine security challenges in a post-9/11 context, but they also use instrumentally the new world order to reposition themselves vis-à-vis the USA and the existing international power structure. 
The general section made a case for a changed security "reality," as seen through a Western lens, in the post-9/11 era. Countries' security priorities changed considerably, state institutions - including defence establishments - were altered significantly and new ones were established to tackle the latest security concerns, while officials and independent experts alike agreed that the world entered a new stage, characterized by a novel threat environment. There has been disagreement over the meaning and depth of these changes, but wide understanding that the world was no longer, in security terms, the place it used to be prior to $9 / 11$. Terrorism, WMD proliferation, failed and failing states, against the background of tackling insurgent forces in theatres such as Afghanistan and Iraq, rose to the top of Western countries' security agendas.

The analysis of the two case studies (Canada and Romania) advanced arguments supporting the idea of largely indistinguishable boundaries between external and domestic threats in a Western context. From a Canadian and Romanian perspective, it was the external environment that constituted the primary source of security threats to these countries and, by extension, to Western polities, but they presented the potential to materialize on domestic soil. Despite a number of potential terrorist attacks on Canadian and Romanian territory being allegedly foiled by authorities and a growing emphasis on homeland defence, the general official view was that threats originated - physically and ideologically - first and foremost from beyond these countries' borders. The overview of state responses to the new international environment, following the events of $9 / 11$, was provided in the two sections on Canada and Romania to underscore the extent to which their respective governments perceived the post-9/11 era as a radical departure from previous years. 


\section{The Transformation of Military Affairs}

\section{IV.1. Introduction}

This chapter investigates the factors that constitute intermediate or intervening variables in the context of this study. While the threat environment, analyzed in the previous chapter, acts for the purposes of this thesis as the independent variable, several developments in field of security and defence link analytically this new threat environment to potential changes in civil-military relations. Five such areas have been identified as intervening variables - that is, they are a consequence of the new security milieu and also contributing factors to changing patterns of interaction between the civilian and military leadership in a national context.

Although the list of intervening variables is potentially longer, five such factors have been identified as prominent during the post-9/11 period: (i) general indicators of recent developments related to the defence establishment, most notably levels of defence spending; (ii) the shaping of government policies in the areas of security and defence; (iii) the transformation of armed forces at multiple levels; (iv) the role of the United States in the new world order and the repositioning of other countries in relation to the world's sole superpower; and (v) responses to the new threat environment, with a focus 
on the role of the armed forces in addressing the new security challenges. The analysis of these five areas helps frame the discussion of civil-military relations, which will be conducted in Chapter V of this thesis - without a proper foundation, provided by the current chapter, an assessment of the civil-military interaction vis-à-vis these topical matters would become a daunting task.

It is hoped that the investigation of these factors provides not only the analytical bridge between the broader security changes noticed in recent years and novel arrangements in the area of civil-military relations, but also evidence for what is generally acknowledged to be a new way of conceptualizing defence, based on the existence of a novel set of threats and strategic priorities. The next section of this chapter will approach the five factors from a general perspective, whereas the following two sections will examine the particular situation on these topics from the national perspective of Canada and Romania respectively.

\section{IV.2. General considerations}

The nature of the post-Cold War and particularly post-9/11 security environment has led to profound changes in patterns of warfare, new government policies and military doctrines, as well as roles for the armed forces that are significantly different from the Cold War understanding of what military establishments were expected to do. The institutional structure of the military (at least in the Western world) has been altered as well, through changes in command and control mechanisms, an emphasis on particular 
types of services rather than others, the creation of new bridges between the military establishment and various civilian organizations and novel ways of interaction between different branches of the armed forces.

Military and civilian organizations alike have adapted to new security realities, in which the armed forces have continued to play a role at least as significant as during the Cold War. Following the end of their confrontation with the Soviet Union and particularly in the post-9/11 era, Western governments have continued to rely heavily on armed forces to ensure the security of their citizens and the protection of their national interests around the world. Yet, along with a perception that something has changed in the international arena following the terrorist attacks of September 11, 2001, among others in relation to the nature of global threats, there has been increased awareness of the changing nature of warfare. Moreover, as Rod Lyon pointed out, "[s]eeing terrorists as war-makers is important to our understanding of the contemporary strategic order, but we need to be careful about what we do with this perception. Terrorism itself cannot fully be addressed merely through military responses."240

It had become clear since the collapse of the Soviet empire that the international wars that Western countries had to engage in no longer presupposed conventional military clashes, whose iconic image is perhaps the tank battle, or nuclear standoffs. Even prior to $9 / 11$, military commanders and policy makers had seen the need for a re-conceptualization of the ways in which the armed forces were employed in various missions and theatres of operations based on the requirements of a qualitatively different battlefield. The image of

\footnotetext{
${ }^{240}$ Rod Lyon, "Civil-Military Relations in an Age of Terror."
} 
massive forces massed along a country's borders to counteract another state's aggressive military action or the idea of another Cuban Missile Crisis seemed to become, during the post-Cold War, increasingly anachronistic. The focus shifted instead toward the need to intervene in low-level conflicts and civil wars, to respond to insurgencies, guerrillas and resistance forces, to prevent or put an end to humanitarian disasters, and - particularly after September 11, 2001 - to fight global terrorism.

These trends mark an undeniable departure from conventional warfare, with its emphasis on the use of uniformed, large-scale forces employed in the fight against similar counterparts, which characterized much of recent history. The reality of contemporary warfare, as John Ralston Saul argued, is no longer based on the idea of "classic, clean victories in which you defeat the enemy and they admit that they were defeated, after which both sides come to an arrangement such as a peace treaty. That is not the world in which we live today. ${ }^{241}$ New strategies, tactics and even weaponry make contemporary warfare significantly different from previous organized fighting.

In Western liberal democracies, the new approaches to military intervention have been largely dictated by the spread of irregular warfare in other parts of the world; this has pushed the transformation of Western military establishments in the same direction, so that they can respond effectively to these novel security challenges. While struggling to strike the right balance between conventional capabilities and new tools for fighting wars of an increasingly sophisticated nature, the armed forces and their civilian masters have

\footnotetext{
${ }^{241}$ John Ralston Saul, “A New Era of Irregular Warfare?," Canadian Military Journal, vol. 5, no. 4 (Winter 2004-2005), 10.
} 
to develop appropriate responses to a fluid security environment. One of the difficulties for military commanders in the field is related to the need to accommodate the requirements of successful military action with the imperative of ongoing interaction between the armed forces and its many civilian partners. Discussing the idea of interagency coordination, Rod Lyon argued that "counter-terrorism is still primarily a form of OOTW [operations other than war]. Like other OOTW, it requires our militaries to work in close cooperation with civilian agencies and partners."242

As US Secretary of Defence Donald H. Rumsfeld pointed out shortly after $9 / 11$, "wars in the twenty-first century will increasingly require all elements of national power: economic, diplomatic, financial, law enforcement, intelligence, and both overt and covert military operations." 243 The United States' policy in this respect, Canada's "3D" approach (defence, development, diplomacy) or Romania's UN-based DDR strategy (disarmament, demobilization, reintegration) are just a few examples of complex reconceptualizations of security missions and the armed forces' role in the larger picture of contemporary security operations.

While the number of unconventional attacks against Western forces, citizens, physical infrastructure and interests has gone up in recent times, there has been growing awareness among Western military commanders, civilian experts and policy makers that their responses have to be brought in line with the imperatives of asymmetric warfare. That is, they have to gain a better understanding of asymmetry as strategy and irregular warfare

${ }^{242}$ Rod Lyon, "Civil-Military Relations in an Age of Terror."

${ }^{243}$ Donald H. Rumsfeld, "Transforming the Military," Foreign Affairs, vol. 81, issue 3 (May/June 2002), 30. 
as the tactical approach of choice on the part of groups that possess lower levels of conventional capabilities. Michael Ignatieff pointed to the importance of four types of asymmetries that people making military decisions in the West have to be aware of: asymmetry of power ("the weak against the strong"), of weaponry ("low-tech against high-tech"), of organization (people holding, or lacking, the status of "armed combatants" of a state) and of morality (combatants who obey, or do not obey, "the same rules you do"). ${ }^{244}$

One of the responses on the part of Western governments has been to increase the role of special operations forces within their military establishments and to deploy them, overtly or covertly, to other countries in the fight against terrorists, insurgents, guerrilla groups or conventional armed forces. ${ }^{245}$ In the years following September 11, 2001, many Western countries - Canada and Romania included - followed the example of the United States in increasing the importance of SOF among their military branches, recognizing the qualitatively different nature of post-9/11 warfare. Such changes are part of a larger effort in what has become in recent years one of the primary objectives of Western countries' external security interventions: the fight against global terrorism, alongside preventing WMD proliferation and lessening the impact of failed and failing states on the international community.

\footnotetext{
${ }^{244}$ Michael Ignatieff, "Ethics and the New War," Canadian Military Journal, vol. 2, no. 4 (Winter 20012002), 7.

${ }_{245}$ According to a generally accepted definition, modern SOF are "specially organized, trained and equipped military and paramilitary forces that conduct special operations to achieve military, political, economic or informational objectives by generally unconventional means in hostile, denied or politically sensitive areas" (Colonel Bernd Horn, "When Cultures Collide: The Conventional Military/SOF Chasm," Canadian Military Journal, vol. 5, no. 3 (Autumn 2004), 3).
} 
Since deterrence does not work when dealing with terrorists willing to sacrifice their own lives for radical political causes and conventional military action may not be successful in targeting non-uniformed insurgents, new structures and strategies have been added to current security interventions. In the context of crisis management, these are "a continuum of military operations that begin when first efforts are made to prevent an armed conflict. They peak during the peace enforcement intervention and they continue at varying degrees of intensity throughout the post-conflict phase."246 While most Western governments argue that the best defence in the fight against global terrorism is a good offence, they also recognize the limitations of purely military intervention in achieving their desired security goals.

While the perceived cause of violence on the part of terrorist groups and other radical organisations is debatable (poverty, world inequity, religious fundamentalism, specific political demands, etc.), many civilian and military leaders in the West promote the idea of long-term presence in conflict areas and support to troubled countries for stabilization purposes. The terrorist incidents of September 11, 2001, were an example of the dangers incurred by insufficient international efforts to address state failure and political extremism in various countries and regions. It is in this context that Stephen D. Krasner and Carlos Pascual point to "unprecedented acknowledgement throughout the world of the need to work together to prevent or manage state failure - and that not doing so would threaten international security."247

\footnotetext{
${ }^{246}$ Col. Klaus Naumann, "The Responsibility to Protect - Humanitarian Interventions and the Use of Military Force," Canadian Military Journal, vol. 5, no. 4 (Winter 2004-2005), 30.

${ }^{247}$ Stephen D. Krasner and Carlos Pascual, "Addressing State Failure," Foreign Affairs, vol. 84, no. 4 (July/August 2005), 152.
} 
In the post-Cold War era and particularly in the post-9/11 context, countries throughout the Western world have recognized their responsibility to provide security to their citizens and stability abroad by intervening militarily and by other means in troubled areas. To do so, they have had to revisit security policies and military doctrines, and to proceed vigorously with a process of transformation of their armed forces. This process has to take into account the need for leaner, more agile, increasingly decentralized armed forces, capable to interoperate more easily with external entities. The transformation is seen as reaction to a new type of warfare that emphasizes precision, asymmetry and novelty rather than massive force and mass destruction. In such a context, the nature of military missions changes and the structure of military services is revamped.

Today's armed forces have to engage in a myriad of operations ranging from direct combat to post-conflict reconstruction; their theatres of operations range from own national territories to faraway places, on mandates received from their governments and from international security organizations. David S. Alberts and Richard E. Hayes also point to additional elements that challenge military organizations to pursue a radical process of transformation in the new security environment: given the complexity of current military operations and the duration of missions or conflicts, "the [command and control] system, operating concepts, and forces will need to prove effective in new and emergent contexts." 248 Military organizations that are agile enough to respond to what

\footnotetext{
${ }^{248}$ David S. Alberts and Richard E. Hayes, Power to the Edge: Command and Control in the Information Age (Washington, DC: US Department of Defense, 2004), 134.
} 
most analysts see as a qualitatively new security environment represent the model for armed forces' transformation.

In a fluid international milieu and in a context in which the nature of particular missions changes significantly over time, a military establishment should be able to match quickly and efficiently its assigned goals with the conditions on the ground. It has to approach its area of competence from a new standpoint since "the emerging threats are different and are continuing to evolve, as well as because our legacy force structure and concepts of operations are not well suited for the tasks at hand, nor are they agile enough to keep abreast of the continuing changes." 249 In parallel with the growing acceptance of special operations forces in overt security operations, we have witnessed, following the end of the Cold War, an increased reliance on novel tools, including information technology, within the larger military establishment.

What has come to be known as a Revolution in Military Affairs (RMA) is defined by some analysts as a major revision in the way armed forces are employed by many Western countries: this transformation is "brought about by the innovative application of new technologies which, combined with dramatic changes in military doctrine and operational and organizational concepts, fundamentally alters the character and conduct of military operations. $" 250$ Many of the examples related to RMA come from the short and highly effective US-led intervention against Iraq in the early 1990s, which seemed to

\footnotetext{
${ }^{249}$ Ibid., 2.

${ }^{250}$ Jeffrey McKitrick et al., "The Revolution in Military Affairs," in Battlefield of the Future: $21^{\text {st }}$ Century Warfare Issues, ed. Barry Schneider and Laurence E. Grinter (Maxwell Air Force Base, AL: Air University Press, 1995), 65.
} 
prove the profound impact on warfare of sophisticated technologies and their use in monitoring the enemy forces' position, disabling their information systems or conducting guided missile strikes. A large number of commentators have noticed, however, that the First Gulf War may have been an exception in this respect and that subsequent military conflicts have combined the use of conventional and RMA-type technologies and tactics.

Recalling the first stages of the US-led military intervention against Afghanistan after 9/11, former US Secretary of Defense Donald H. Rumsfeld made an interesting point: "Here we were, in 2002, fighting the first war of the twenty-first century, and the horse cavalry was back $[\ldots]$. It shows that a revolution in military affairs is about more than building new high-tech weapons - although that is certainly part of it. It is also about new ways of thinking and new ways of fighting. ${ }^{.251}$ It seems clearer now that early positions on the revolution in military affairs were overly optimistic: RMA has not cleared Clausewitz's "fog of war" nor has it led to a situation in which losing own soldiers' lives on the battlefield is a thing of the past.

There are still open questions related to RMA's "nature [...], its likely development, and its implications for various nations, the future of warfare, and defense policy, ${ }^{, 252}$ and the extent to which new technologies "are being translated into the doctrinal and organizational changes that are necessary for an RMA to take hold." ${ }^{253}$ Yet, while

\footnotetext{
${ }^{251}$ Donald H. Rumsfeld, "Transforming the Military," 21.

${ }^{252}$ Thierry Gongora and Harald von Riekhoff, introduction to Toward a Revolution in Military Affairs? Defense and Security at the Dawn of the Twenty-First Century, ed. Thierry Gongora and Harald von Riekhoff(Westport, Connecticut and London: Greenwood Press, 2000), 1.

${ }^{253}$ Elinor Sloan, "Terrorism and the Transformation of US Military Forces," Canadian Military Journal, vol. 3, no. 2 (Summer 2002), 19.
} 
scholars and practitioners do not seem to agree on one definition of RMA, most would be in agreement that significant changes have occurred in recent years in the use of military technologies and in patterns of warfare. Many of these changes have been initiated in the process of transformation of Western militaries following the terrorist attacks of September 11, 2001.

Such military-related responses to the new security environment can be detected both at the level of specific countries and in the context of multinational organizations, such as the North Atlantic Treaty Organization. One of the first countries to engage in a systematic process of transformation of its armed forces and their interaction with civilian organizations following the attacks of September 11, 2001, has been - unsurprisingly the United States. It was US Secretary of Defense Donald Rumsfeld's position, immediately following the $9 / 11$ terrorist incidents, that the process of transformation of the United States' armed forces and their military doctrine may even be facilitated, rather than hindered, by wartime. The country's political leadership approached the subsequent military campaigns against terrorist and insurgent groups as the catalyst for a process that had begun after the end of the Cold War, but had not gone far enough in meeting the challenges of what 9/11 seemed to signal: a qualitatively different international threat environment.

Collectively, NATO itself was pursuing a process of transformation, based on the requirements of the post-9/11 threat environment. "Recalling the tragic events of 11 September 2001," the North Atlantic Treaty Organization's Prague Summit (November 
2002) has approved "a comprehensive package of measures, based on NATO's Strategic Concept, to strengthen [its] ability to meet the challenges to the security of our forces, populations and territory, from wherever they may come." ${ }^{254}$ For the first time in its history, NATO invoked on September 12, 2001, Article 5 of the founding Washington Treaty (1949), its mutual defence clause: the terrorist attacks of 9/11 were declared an armed attack on all NATO members.

NATO AWACS aircraft were deployed to the United States the following month and several operations were launched under US leadership, the two most significant in the Mediterranean Sea (maritime operation Active Endeavour, since October 2001) and in Afghanistan (International Security Assistance Force, authorized by the United Nations Security Council in December 2001 and formally led by NATO since August 2003). Both Active Endeavour and ISAF were designed and run specifically to deal with threats posed by terrorist and insurgent groups. The Atlantic Alliance expanded its area of competence in Afghanistan by setting up Provincial Reconstruction Teams (PRTs), which were defined as "teams of international civilian and military personnel working in Afghanistan's provinces to extend the authority of the central government and to provide a safer and more secure environment in which reconstruction can take place."255

These measures marked an important milestone in NATO's transformation, since they emphasized specifically the imperative of adapting armed forces' mission and actions to

254 ***, "Prague Summit Declaration," http://www.nato.int/docu/pr/2002/p02-127e.htm, November 21, 2002 (accessed December 5, 2005).

255 ***, "Response to Terrorism," http://www.nato.int/docu/briefing/rtt-e.pdf, March 2005 (accessed January 5,2006$)$. 
the structural conditions of a novel security environment. At NATO's Prague Summit of 2002, the Alliance's leaders discussed the need for "a leaner, more efficient, effective and deployable" command structure, "a technologically advanced, flexible, deployable, interoperable and sustainable" NATO Response Force (a first in the decades-long history of the Alliance) and "new military capabilities for modern warfare in a high threat environment," among others in the areas of chemical, biological, radiological, and nuclear defence. ${ }^{256}$ The Prague Summit and subsequent high-level NATO meetings identified terrorism (alongside WMD and failed and failing states) as a most significant threat to the stability of the world and endorsed NATO's newly-created Military Concept for Defence against Terrorism.

Afghanistan in particular represents, in the post-9/11 era, a theatre of operations that illustrates compellingly the necessity of adapting armed forces and military responses to the requirements of a new international threat environment. It underscores the saliency of firm action on the part of the international community in attempting to root out terrorism and addressing the challenges of a failed or failing state. It exemplifies the devastating impact on a country, its region and the whole world of terrorism (including the statesponsored kind) and insurgent activity. Afghanistan also shows the extent to which twenty-first century warfare marks a significant departure from previous ways of fighting, of approaching the enemy and interacting with the larger population. It emphasizes as well the need for new government policies and military doctrines, and new institutional structures for the armed forces, so that Western military establishments can address effectively today's security realities. Finally, Afghanistan is a place where large 256 ***, "Prague Summit Declaration." 
contingents of Canadian and Romanian troops have been deployed in the years following the $9 / 11$ attacks, therefore it contributes to a consistent comparative analysis of Canadian and Romanian positions vis-à-vis the current threat environment (an analysis of which will be provided later in this chapter).

Afghanistan became a recognized source of instability and concern for the international community in mid-1990s, when an Islamic fundamentalist group, the Taliban, took control by force over the national government and, later on, allowed terrorist leader Osama bin Laden to run the operations of his organization, al-Qaeda, from this country. When 9/11 occurred, Afghanistan was the obvious target for a US-led military intervention. Yet, while the Taliban regime was swiftly removed from power in 2002, after US troops supported by local fighters (particularly the Northern Alliance) launched a sustained military attack against it, both al-Qaeda and the Taliban regrouped for what proved to be a long insurgency.

To date, coalition forces have not managed to capture the two organizations' leaders, Osama bin Laden and Mullah Mohammed Omar, although both are thought to hide in Afghanistan or in neighbouring Pakistan. Combined with presumed support from other terrorist groups and countries in the region, a core of Taliban and al-Qaeda fighters has been able to challenge the efforts for Afghanistan's reconstruction. Although generally unable to "hold territory or defeat coalition troops in battle," these insurgents are "capable of staging ambushes, kidnappings, beheadings, road-side bombings and suicide 
attacks, ${ }^{, 257}$ which pressures Afghan and coalition forces to adapt their own strategies to the situation on the ground.

The NATO-led International Security Assistance Force (which also comprises nonNATO countries) is the biggest such operation ever to be undertaken by the Atlantic Alliance outside Europe - involving up to 15,000 troops in 2006 - and one of the most challenging in terms of location, tactics, inter-agency arrangements, the nature of missions and the type of enemies encountered. Similar to the North Atlantic Treaty Organization's intervention in Kosovo in the late 1990s and the early 2000s, NATO's Afghanistan operations are multi-faceted assignments, meant to provide stability to the country as a whole and to engage in nation-building and reconstruction.

Despite real progress made by the United States and its allies in the first five years in Afghanistan, coalition forces and a weak Afghan National Army (ANA) were in no position in late 2006 to claim wide control over areas outside key urban centres - even there they faced strong resistance from Taliban elements, groups sympathetic to al-Qaeda and other radical elements. Rebuilding the country and providing it with a safe security environment still proved to be, in mid-2008, a formidable challenge for its national government and the international community, despite considerable advances made by coalition forces in adapting to new strategic realities.

The Afghan situation reflects the difficulties faced by governments and armed forces reacting to the threats of this new era, chief among them international terrorism, WMD

257 ***, "The New Taliban," The Globe and Mail, January 17, 2006. 
proliferation and failed and failing states. Not only that success in various security operations is hard to define and is, quite often, an elusive goal; but there is no clear consensus on a wide array of issues, ranging from levels of defence spending and appropriate government policies vis-à-vis these new security challenges to strategies and mechanisms for armed forces' transformation to the best configuration of military responses, as well as bilateral and multilateral international relations. (Chapter $\mathrm{V}$ will assess how all these obstacles play out in terms of civil-military relation in two national contexts, Canada and Romania).

\section{IV.3. Case study: Canada}

IV.3.a. Defence background

The end of the Cold War brought with it not only new patterns of international relations, but also dramatic changes in the way security was conceptualized and acted upon at national level. In Canada, like in most other Western countries, there was a sense that the world had entered a less violent era and that a peace dividend was to be expected. State resources were supposed to be redirected, to a significant extent, from defence to economic and social programs - the "guns versus butter" argument gained solid ground, at least in the early 1990s. Developments in the first decade following the end of the Cold War era rendered this reasoning irrelevant, yet the process of scaling down the armed forces - to about 60,000 regular troops today - and cutting back funding for security and defence programs had already begun. 
Among others, the Canadian Forces were affected by important budget cuts, while the governments of the day still kept the military's operational tempo high, by sending troops on various missions around the world. This became known as the capability-commitment gap, a problem that most defence analysts said affected negatively the effectiveness and the morale of the Canadian Forces in recent years. Not only was the number of post-Cold War operations high, but the intensity of the Canadian Forces' overseas engagements (an estimated 40 missions) was also soaring constantly since the early 1990 s. Although most missions have been presented as peacekeeping assignments, Canadian Forces (CF) personnel were involved, as early as 1993, in active combat. Former Assistant Deputy Minister (Policy) at the Department of National Defence Kenneth Calder pointed out that, starting with the end of the Cold War and moving into the post-9/11 era, we witnessed a "pattern of significant, dangerous operations" involving the Canadian Forces. ${ }^{258}$

At Medak Pocket in Croatia (1993), Canadian soldiers engaged local troops in conventional war fighting; despite romantic images at home portraying Canadians as neutral, blue helmet-wearing arbiters, experts present the Medak Pocket intervention as "the most violent Canadian military engagement in the half century between the Korean War and the War in Afganistan." ${ }^{259}$ However, the CF involvement in Somalia (1993) and Rwanda (1994) inflamed Canadian public opinion and contributed to loss of confidence in the Canadian Forces. In the first case - what has become known as the "Somalia

${ }^{258}$ Interview with Kenneth Calder (former Assistant Deputy Minister, Policy, Department of National Defence of Canada), by the author, Ottawa, ON, July 9, 2008.

${ }^{259}$ Scott Fitzsimmons, book review of The Ghosts of Medak Poket: The Story of Canada's Secret War, by Carol Off (Toronto: Random House Canada, 2004), Canadian Military Journal, vol. 6, no. 1 (Spring 2005), 87. 
Affair" - the CF leadership was accused of covering up the beating death of a Somali teenager by two Canadian soldiers; in the latter case, Canada saw its troops, under UN leadership, unable to prevent the Rwandan genocide, which reportedly led to the slaughter of about 800,000 Tutsi by the Hutu majority in just a few months.

At home, the Canadian Forces became involved, as a "force of last resort," in several controversial interventions against armed Native groups: in Oka, QC (Operation SALON) in 1990; at Gustafsen Lake, BC (Operation WALLABY) in 1995; and in Ipperwash Provincial Park, ON (Operation MAPLE) in 1995. It also intervened in the socalled Turbot War of 1995, a fishing dispute between Canada and the European Union, by seizing a Spanish trawler off the coast of Newfoundland, while "a submarine was deployed to covertly observe illegal scalloping operations." ${ }^{260}$ In the area of disaster relief, the Canadian Forces have provided assistance both abroad and at home - e.g., the Red River, MB, flood (Operation ASSISTANCE) in 1997; the Central/East Canada ice storm (Operation RECUPERATION) in 1998; and the Peggy's Cove, NS, activities following the crash of Swissair flight 111 (Operation PERSISTENCE) in 1998. The Disaster Assistance Response Team (DART), formed in 1997, would be deployed in Honduras (Operation CENTRAL) in 1998; in Turkey (Operation TORRENT) in 1999; in Sri Lanka (Operation STRUCTURE) in 2005; and in Pakistan (Operation PLATEAU) in 2005.

Despite the fact that the post-Cold War international security environment was amorphous and threat assessments presented contradictory pictures of the security

${ }^{260}$ Sean M. Maloney, “Force Structure or Forced Structure?," Choices, vol. 10, no. 5 (May 2004), 22. 
situation, the Canadian Forces would begin in the mid- and late 1990s a complex process of regeneration that would prove appropriate in light of post-9/11 realities. The changes were meant "to improve leadership and management of the $\mathrm{CF}$, modernize and enhance the fairness of the military justice system, increase openness and transparency, and strengthen professional development and ethics. ${ }^{.261}$ In addition to these developments as the intervention in Kosovo (Operation KINETIC) in 1999-2000 would seem to suggest - the Canadian Forces moved toward a lighter structure and a more flexible way of conducting missions.

Even prior to the events of September 11, 2001, Canada's military establishment emphasized increasingly the importance of special operations forces, its capacity to counter WMD proliferation and its level of preparedness for intervention in collapsed and weak states or in protecting Canada's coastlines and its Far North. Retrospectively, Sean M. Maloney sees the Canadian experience as "a combination of what American doctrine calls 'unconventional warfare' $[\ldots]$, counter-terrorism $[\ldots]$, security assistance, and irregular support to conventional operations," 262 a view shared by other defence analysts as well. This seems to have become the norm post-9/11, with Canadian troops fighting a new kind of war in Afghanistan, a place where they confront - according to Prime Minister Stephen Harper - the "menace of terror."263

\footnotetext{
261 ***, A Time for Transformation: Annual Report of the Chief of the Defence Staff (2002-2003), http://www.cds.forces.gc.ca/pubs/anrpt2003/intro e.asp, 2003 (accessed April 18, 2006), 15.

${ }^{262}$ Sean M. Maloney, "Who Has Seen the Wind?: An Historical Overview of Canadian Special Operations," Canadian Military Journal, vol. 5, no. 3 (Autumn 2004), 39.

${ }^{263}$ Cited in: Kathleen Harris, "'Sacrifice and risk' vital, PM warns," The Ottawa Sun, September 12, 2006.
} 
The most important debate regarding the Canadian Forces following the end of the Cold War centred, however, on a perceived shortage of resources and personnel, the apparent imbalance between funding and operational commitments, and the optimum level of the country's defence budget. "So cash-strapped is the army," a commentator pointed out, "that it has stopped buying spare parts for many of its vehicles, as well as many other supplies. ${ }^{\text {264 }}$ Other analysts warned that Canada would become the first country in the Western world without armed forces: with crumbling infrastructure, burned out personnel and no strategic lift capability, the Canadian Forces would disappear in the near future. Colin Kenny, Chairman of the Standing Senate Committee on National Security and Defence, argued that a defence budget increase of $\$ 4-5$ billion a year was necessary "not just to make the military more effective, but to keep it solvent."265

Other experts disagree, however, arguing that - although it spends comparatively less money on defence than most other NATO countries - Canada is still "one of the biggest spenders in the Western alliance."266 Terry Copp says the Canadian Forces are "about the right size for a small, middle power such as Canada" and Joel Sokolsky argues that increases in Canada's defence budget "would afford Ottawa no measurable increase in its ability to influence the direction of American policy.,267 Civil-military disagreements over these matters will be investigated at length in Chapter $\mathrm{V}$ of this thesis. The next subsection will provide an overview of the second intermediate variable, the shaping of government policies in the areas of security and defence.

\footnotetext{
${ }^{264}$ Richard Foot, "Tug of War," Ottawa Citizen, September 25, 2004.

${ }^{265}$ Ibid.

${ }^{266}$ Chris Wattie, "Why $\$ 13.6 \mathrm{~B}$ a year isn't enough to run our military," Ottawa Citizen, September 28, 2004.

${ }^{267}$ Cited in: Richard Foot, "Tug of War."
} 


\section{IV.3.b. Government policies}

The reconfiguration of Canada's foreign, security and defence policies became a clear necessity in a context in which - as Prime Minister Paul Martin pointed out - "[o]ur security, our prosperity and our quality of life all stand to be influenced and affected by these global transformations and by the challenges they bring." 268 This position was taken one step further in 2006 by Prime Minister Stephen Harper's Conservative Government. Although its "Canada First" electoral platform was not very specific on the importance given to expeditionary forces overseas, the new government became a staunch supporter of Canada's intervention in Afghanistan. It also promoted measures boosting the defence budget and improving defence capabilities at home; as Martin Shadwick pointed out, "[s]omewhat paradoxically, the heightened attention to homeland defence and sovereignty protection could also reassure the United States about Canada's commitment to enhanced continental security in the post-9/11 environment.",269

The remainder of this subsection will take a more detailed look at the two most important policy documents in the areas of security and defence during the period covered by this study: the 2005 International Policy Statement and the 2004 National Security Policy.

\footnotetext{
${ }^{268}$ Paul Martin, "Making a Difference," in Canada's International Policy Statement: A Role of Pride and Influence in The World (Overview), http://www.dfait-maeci.gc.ca/cip-pic/IPS/IPS-Overview.pdf, 2005 (accessed March 8, 2006), iii.

${ }^{269}$ Martin Shadwick, "Defence and the Conservatives," Canadian Military Journal, vol. 7, no. 1 (Spring 2006), 73 .
} 
IV.3.b.i. 2005: The International Policy Statement

In April 2005, the Liberal Government released an International Policy Statement, the first document of its kind to integrate all the state's major international tools. The document articulated Canada's international priorities in four key areas of interest: defence, diplomacy, development and commerce. All IPS sections were inspired by the idea of a more active Canada on the international stage, a country that has to reposition itself in relation to a new global environment, including new and more challenging security threats. An international policy at a crossroads: that's how many analysts described, in a nutshell, the main purpose and the key objective of the International Policy Statement.

IPS was designed as a novel lens offering optimized reflections of a changing world in which Canada tries to find a place for itself, but also as a platform for further conceptualization of government positions on international affairs. It focused on a more dynamic diplomacy and the rethinking of relations with emerging world powers, a stronger emphasis on development cooperation and a clearer set of criteria for providing bilateral aid, the reconfiguration of Canada's priorities in the area of international commerce and the overhaul of the country's defence and security priorities.

The International Policy Statement repeatedly underscored the importance of implementing what became known as Canada's "3D" approach (diplomacy, defence and 
development) to overseas operations. The philosophy behind IPS represented a "tidal wave" in government thinking on foreign, security and defence policies: among others, Canada was portrayed as a country under potential attack, which had to act forcefully outside its borders to make sure its opponents' violent objectives do not materialize. To increase the likelihood of success in its operations abroad, Canada has to mobilize a wide array of resources and organizations, in finely coordinated missions. Defence and security issues are discussed extensively in the Defence Policy Statement (DPS) - this IPS section was meant to update the country's priorities and positions relating to the new international threat environment (particularly in the post-9/11 context), the transformation of the Canadian Forces, Canada-US defence relations and the military's participation in domestic, continental and overseas operations.

Among chief security and defence priorities, DPS focused on the protection of North America, the fight against international terrorism, efforts to prevent the proliferation of weapons of mass destruction and effective intervention in failed and failing states. The last of those was presented as necessary not only based on humanitarian concerns, but also on Canada's direct security interests: while contributing to the reconstruction of wartorn countries, the Canadian Forces and the Canadian Government moved the fight against international terrorism overseas.

"Today's front lines," the Defence Policy Statement argued, "stretch from the streets of Kabul to the rail lines of Madrid to our own Canadian cities," pointing to the 
interconnection of domestic and external security ${ }^{270}$ Acknowledging the existence of an "increasingly interdependent world," the document underscored the predominantly external nature of (physical and/or ideological) threats, i.e., the fact that they originate primarily beyond Canada's borders, but also the potential dangers they pose to the country's homeland and to North America. "The Government has made a commitment to respond to potential threats to Canadian security before they reach our shores, ${ }^{, 271}$ thus radically altering Canada's security and defence priorities and the Canadian Forces' roles, based on the requirements of the new global security context.

The Defence Policy Statement was not the first major government document to identify terrorism, WMD and failed and failing states as major security threats to Western countries such as Canada. Other government documents and official positions, as well as independent analyses, had focused, prior to 2005 , on the same range of security challenges. Yet the major contribution of DPS was to clearly place these threats in what was perceived to be a new era in international affairs (for $9 / 11$ "reset the international policy agenda") and to identity the need for proactive policies in counteracting them, preferably beyond Canada's borders. Its principles were firmly grounded in the realities of a post-9/11 threat environment: "[s]ecurity in Canada ultimately begins with stability abroad," DPS argued, pointing to the necessity for Western countries to intervene in failed and failing states. ${ }^{272}$ The inability of these latter polities to provide political goods to their citizens, especially security, was presented as threatening regional and global

\footnotetext{
${ }^{270}$ Department of National Defence, Defence Policy Statement, http://www.forces.gc.ca/site/reports/dps/index_e.asp, 2005 (accessed March 10, 2006), 5.

${ }^{271}$ Ibid., 5.

${ }^{272}$ Ibid., 2.
} 
stability; they can constitute breeding grounds or safe havens for international terrorist organizations and organized crime groups.

While promoting the idea of more vigorous, effects-based, three-block war operations abroad (the away game), the document placed, however, particular emphasis on the protection of Canada and North America (the home game): "[t]his must be the Canadian Forces' first priority." ${ }^{, 273}$ It stressed the fact that the sense of invulnerability enjoyed by Canada prior to September 11,2001 , as a country protected by three oceans and a friendly neighbour, was shattered, along with the United States'. In the new strategic environment, Canada has an even greater duty to protect its territory and its citizens from terrorism and related threats - if necessary by conducting combat missions - and to avert attacks against its southern neighbour.

As a blueprint for action in the international realm, IPS was a useful addition to Canada's policy toolbox, received positively by practitioners and scholars alike. Its role in setting the Government's agenda on a novel international milieu is particularly significant in the process of Canada's repositioning vis-à-vis the new world order. In the areas of defence and security, the International Policy Statement provided both specific guidelines and strategic direction to tackle threats associated with the post-9/11 threat environment - in Canada, in North America and abroad. The defeat of Paul Martin's government one year later would, nonetheless, minimize the impact of this document within official circles; the Conservatives" "Canada First" outline would replace IPS as the key security and defence blueprint.

${ }^{273}$ Ibid. 
IV.3.b.ii. 2004: The National Security Policy

A precursor of IPS, Canada's National Security Policy was released by the government of the day in April 2004. NSP listed among chief threats to Canada's security and stability terrorism, the proliferation of weapons of mass destruction and failed and failing states, along with foreign espionage, natural disasters, critical infrastructure vulnerability, organized crime and pandemics. "Throughout our history," Prime Minister Paul Martin pointed out in its introductory section, "we have managed a wide range of threats to our society - from the influenza pandemic of $1918-19$ to the risk posed by Soviet bombers that led to the creation of NORAD [the North American Aerospace Defence Command].",274

The first such document ever released in Canada, the National Security Policy focused on addressing three core security interests: "protecting Canada and Canadians at home and abroad; ensuring Canada is not a base for threats to our allies; and contributing to international security. ${ }^{275}$ Despite its comprehensive listing of threats, risk factors, priorities and response measures, NSP was, nonetheless, less specific than the Government's 2005 International Policy Statement about the interaction between these elements. Careful consideration is given, however, to the events of September 11, 2001, and their impact on the understanding of threat domestically and in the international arena. Terrorism is thus presented not as an incidental occurrence (NSP was released

${ }^{274}$ Privy Council Office, Securing an Open Society: Canada's National Security Policy, http://www.pcobcp.gc.ca/docs/Publications/NatSecurnat/natsecurnat_e.pdf, April 2004 (accessed March 11, 2006).

${ }^{275}$ Ibid., vii. 
after the Madrid attacks of March 11, 2004), but rather as a systematic phenomenon which can have a dramatic impact on the world's economic life and political systems.

While the National Security Policy established many of the ideas that could also be identified in IPS, such as the strategic decision to deploy Canadian troops overseas to counteract threats before they reach Canadian shores, it was rather vague in linking precisely international developments to domestic threat levels. Critics argue, for instance, that clearer criteria and a more compelling argumentation should have been provided regarding intervention in failed and failing states. What it did provide, nonetheless, was a new approach to security: as Deputy Prime Minister Anne McLellan put it, “an integrated effort across the Government and with a range of partners - domestic and international to address threats, ${ }^{, 276}$ at home and overseas.

By shedding some light on the interconnectedness of personal, national and international security, NSP set the terms of the current discussion on present threats and appropriate responses. An important point related to the idea of the exponential rise in dangerousness that comes with the combination of threats, such as terrorism and weapons of mass destruction. Acknowledging, for instance, the need to fight a long war against terrorist and insurgent groups and the complexity of this campaign, the National Security Policy pointed to "managing and reducing risks" rather than eliminating such security challenges. $^{277}$

\footnotetext{
${ }^{276}$ Anne McLellan, "Securing Canada: Laying the Groundwork for Canada's First National Security Policy," presentation to the Canadian Club of Ottawa, http://ww2.psepcsppcc.gc.ca/publications/speeches/20040325 e.asp, March 25, 2004 (accessed March 11, 2006).

${ }^{277}$ Privy Council Office, Securing an Open Society, 8.
} 
Overall, all policy documents released during the 2001-2006 period, including the Conservative Party's "Canada First" electoral platform, identified terrorism, WMD proliferation and failed and failing states as key threats to world security. Restructuring Canada's approaches to dealing with these novel security challenges would involve massive changes and would lead to the creation of new institutions and procedures. The third key intermediate variable in the context of this thesis, defence transformation, will be explored in the following subsection, with particular emphasis on the idea of transformation, developments relating to this process and transformation challenges.

\section{IV.3.c. Defence transformation}

IV.3.c.i. The idea of transformation

Both the civilian and the military leadership of the country have acknowledged the need for a process of transformation of Canada's defence establishment and - particularly the Canadian Forces based on the requirements of the new threat environment. "Today, individuals have the power to undermine our security in ways that used to be available only to hostile states. [...] [Terrorists] have long-term objectives, they refuse to follow the traditional rules of war and they are capable of attacking indiscriminately without concern for innocent civilians," Chief of the Defence Staff Gen. Ray Henault argued in 
his annual 2003-2004 report titled "Making Choices." ${ }^{, 278}$ He also pointed, in this vein, at the interconnection of domestic and international security, as the threat of terrorism is enhanced by the existence of transnational radical networks, organized crime groups and failed and failing states.

Gen. Henault also argued in his 2002-2003 report titled "A Time for Transformation" that we now face "a new generation of threats," "different kinds of adversaries," "new forms of warfare and potentially new, horrific weapons." ${ }^{.279}$ A year earlier, in the 2001-2002 annual report of the Chief of the Defence Staff, he had referred to the unpredictable nature of the new international security environment and the serious challenges posed by asymmetric threats to countries such as Canada and their armed forces. ${ }^{280}$ Based on such assessments, Gen. Henault argued strongly - until late 2004, when named chairman of NATO's military committee - for a process of transformation of the Canadian Forces. He was, in fact, one of the most vocal proponents of this idea, but civilian policy makers would engage forcefully in that conversation as well.

Although Gen. Rick Hillier, his successor, was an even stronger, and arguably more effective, advocate of the Canadian Forces' transformation, Gen. Henault set the basic principles of this process during his tenure as Chief of the Defence Staff. Gen. Henault called for a new system of management, a more flexible and leaner organization, novel tactical and operational principles, jointness, interoperability and networking, and

\footnotetext{
278 ***, Making Choices: Annual Report of the Chief of the Defence Staff (2003-2004), http://www.cds.forces.gc.ca/pubs/anrpt2004/intro_e.asp, 2004 (accessed April 18, 2006 ), 2. $279 * * *, A$ Time for Transformation, II.

$280 * * *$, Annual Report of the Chief of the Defence Staff (2001-2002), http://www.cds.forces.gc.ca/pubs/anrpt2002/intro_e.asp, 2002 (accessed April 18, 2006 ), 10.
} 
improved capabilities. He defined transformation as a process with "no definable end" that "focuses on people, technology, ways of conducting operations and ways of thinking. It does not seek to re-equip or re-structure the CF completely, but rather to blend existing and emerging systems and structures to create greatly enhanced capabilities relevant to future missions, roles and tasks." 281

Chief of the Defence Staff Gen. Rick Hillier would call for "new and more flexible capabilities than we have had for the conventional threat," recognizing that conventional threats (such as "an attack by another country using massed infantry and tanks on land") have largely lost their significance, while asymmetric threats ("terrorism, suicide bombers, riots, explosive devices and well-armed militias") are the new enemies of Western armed forces. ${ }^{282}$

\section{IV.3.c.ii. Developments in the transformation process}

In this context, one of the most significant challenges facing Canada's defence community during the post-9/11 period was to make decisions on the best course of action for the transformation of the Canadian Forces. Prime Minister Paul Martin's June 2004 election campaign statement according to which Canada would add 5,000 new troops and 3,000 reservists to the military for peacekeeping missions led to a choir of criticisms from journalists and defence analysts. While new manpower was definitely

\footnotetext{
$281 * * *$, Making Choices, 3 .

$282 * * *$, "Commander Speaks about Army Transformation," http://www.forces.gc.ca/site/Newsroom/view_news_e.asp?id=1239, October 30, 2003 (accessed October $15,2004)$.
} 
welcome, they argued, using the new forces for traditional peacekeeping missions could prove to be a mistake, since the nature of warfare changed dramatically during the postCold War era.

In September 2004, Minister of National Defence Bill Graham indicated that his staff was "considering a range of options for what those new bodies will be doing. The options include adding to existing units, including beefing up Canada's JTF2 special operations forces and troops that would respond to a biological, chemical or nuclear attack. ${ }^{\$ 283}$ Bill Graham's position came in reaction to increasingly numerous assessments according to which today's military interventions take place overwhelmingly in foreign theatres of operations that are more violent than in the recent past. The new missions also require updated strategies to deal with asymmetric treats and the armed forces have to engage in long-term cooperation with other organizations and less formal groups.

Most senior military and civilian leaders supported similar positions following the events of September 11, 2001, although even prior to 9/11 the Canadian Forces had emphasized the need for enhanced capabilities in areas as diverse as special operations; biological, chemical and nuclear defence; intelligence; information operations; research and development; and force protection. ${ }^{284}$ The strongest efforts toward the Canadian Forces' transformation along these lines occurred, however, after the Defence Policy Statement was officially released by the Liberal Government (the content of which was largely shaped by the military, as will be explored in Chapter V).

\footnotetext{
${ }^{283}$ Mike Blanchfield, "We'll make good on our promises of more money, more troops, Graham insists," Ottawa Citizen, September 25, 2004.

284 ***, Annual Report of the Chief of the Defence Staff (2001-2002), 25.
} 
As Craig Stone and Brig.-Gen. Daniel Gosselin explain, "transforming the CF without the benefit of a new defence policy, without an overarching CF vision, and with a limited budget, proved to be near impossible. Consequently, little progress could be made in this regard during General Henault's tenure.,"285 Using IPS as a springboard, Gen. Hillier initiated, in 2005, an overhaul of the Canadian Forces' command and control structure and eventually worked with the Liberal and Conservative Governments toward beefing up the country's defence budget. "[M]ake no mistake about this, we are moving through this transformation at a phased, but aggressive pace," he said in early $2006 .{ }^{286}$

For the first time, Canada was approached in the 2005 Defence Policy Statement as an operational theatre, with its own command structure (the newly created Canada Command), dedicated forces and improved capabilities. Whereas the Canadian Expeditionary Forces Command (CEFCOM) would be responsible for most CF international operations, Canada Command - with its six regional headquarters - was created "to respond to national contingencies." 287 A Special Operations Group (SOG) Command, composed among others of Joint Task Force Two and the Joint Nuclear, Biological and Chemical Defence (JNBCD) Company, would provide support to both Canada Command and CEFCOM. The creation of a Strategic Joint Staff (SJS) to assist the CDS was also announced, as well as a new office of Chief of Force Development (CFD). A 2007 report produced for Chief of the Defence Staff Gen. Hillier indicated,

\footnotetext{
${ }^{285}$ Brig.-Gen. Daniel Gosselin and Dr. Craig Stone, "From Minister Hellyer to General Hillier," Canadian Military Journal, vol. 6, no. 4 (Winter 2005-2006), 9.

286 ***, Transform and modernize the Canadian Forces, http://cds.forces.gc.ca/cft-tfc/intro e.asp, April 2006 (accessed April 18, 2006).

${ }^{287}$ Ibid., 18.
} 
however, that - with most resources directed to the Afghanistan mission - Canada Command remained "very much a command in-waiting," while CEFCOM was "stretched thin."288

The unified and integrated approach to CF operations also entailed the establishment of a Standing Contingency Task Force (SCTF), deployable on a 10-day notice, both at home and abroad, as well as Mission-Specific Task Forces (MSTF). Improved strategic lift capacity, additional troops $(5,000$ regular force personnel and 3,000 reserve personnel) and an increased defence budget ( $\$ 12.8$ billion over five years) were some of the key elements of the Defence Policy Statement, meant to transform the Canadian Forces and improve security in Canada, North America and overseas. In 2006, the Conservative Government would raise the defence budget by an additional \$5.3-billion over five years.

Beefed-up surveillance in the North, supplementary air and maritime capabilities for domestic operations, closer Canada-US cooperation through the temporary Bi-National Planning Group and a renewed NORAD were meant to improve security on the North American continent. "Threats to one country are threats to the other country," Vincent Rigby, then-Director General of the Policy Planning division in the Department of National Defence, pointed out in 2005; "by helping each other, we help ourselves, we defend our citizens. ${ }^{289}$ In the area of emergency planning and management, the 2004 National Security Policy created the position of Associate Minister of National Defence

\footnotetext{
${ }^{288}$ David Pugliese, "Command Performance," Ottawa Citizen, September 4, 2007.

289 Vincent Rigby, presentation at the conference Terrorism, Democracy and Empire, organized by Carleton University, Ottawa, October 1, 2005.
} 
and Minister of State (Civil Preparedness), and underscored the need for additional resources being allocated to the Canadian Forces.

New facilities and capabilities were advocated for CF and other authorities involved in emergency preparedness and support, as well as the creation of a dedicated NBC response unit, to act domestically and abroad. ${ }^{290}$ The area of international security has traditionally been at the core of Canadian Forces' raison d'être and NSP emphasized the idea that "[t]he primary obligation of the Canadian Forces is to defend Canada and Canadians, particularly from external military threats."291 One of the foremost ways to achieve that objective was through strengthening the ability of SOF - the Ottawa-based JTF2 and a new, Petawawa-based Canadian Special Operations Regiment, created in 2006 - in acting effectively at home and abroad against enemy targets. "What we're looking at is high mobility, high training, with both conventional and non-conventional capabilities," said military spokesman Maj. Doug Allison; ${ }^{292}$ his statement reflects the overarching post-9/11 philosophy within the Canadian defence establishment, centred around nimble and lethal armed forces, an organization that can react quickly and successfully to terrorist incidents, insurgent activities and other asymmetrical threats.

\section{IV.3.c.iii. Transformation challenges}

The increasingly complex strategic environment has created a challenge for Western security and defence establishments, as they had to devise new strategies and institutional

\footnotetext{
${ }^{290}$ Privy Council Office, Securing an Open Society, 23.

291 Ibid., 47.

${ }^{292}$ David Pugliese, "Canada to get its own version of Green Berets," Winnipeg Free Press, January 3, 2006.
} 
innovations to deal with novel defence and security realities, and to become increasingly interoperable with allied forces. Threat assessments are often unreliable or controversial mechanisms and the policies to deal with a myriad of security concerns can themselves be inconsistent and open to criticism.

While there was an obvious need for the armed forces to adapt to a radically different threat environment following the end of the Cold War, the exact patterns of that transformation were the subject of heated debate. Although the Canadian military's Defence Science Advisory Board (DSAB) pointed out that, in the post-9/11 context, "it is the threat of terrorism that needs to drive planning and strategy, ${ }^{, 293}$ how the Canadian Forces and the country's security and defence establishment would look like in the medium and long run was still an open question. Some of the debates centred around the optimal model for a military establishment that could protect Canada and Canadians effectively, but was also highly interoperable with Canada's allies, notably the United States, so that it could make a decisive contribution to allied military efforts when needed.

Canadian defence analysts and policy makers argued, for example, over the appropriateness of widening the functions of the military so that it acquires skills other than soldiering (with retired Gen. Romeó Dallaire arguing for and retired Maj.-Gen. Lewis MacKenzie making a case against this idea); ${ }^{294}$ whether Canada should join the United States' missile defence system to get better protection from potential enemy air

\footnotetext{
${ }^{293}$ David Pugliese, "Time to protect the homeland," Ottawa Citizen, October 2, 2004.

${ }^{294}$ Maj.-Gen. (ret'd) Lewis MacKenzie, "Peacemaking is Not Social Work," National Post, Nov. 23, 2004.
} 
strikes or, alternatively, direct resources to less controversial defence projects; ${ }^{295}$ whether or not special operations forces, such as Joint Task Force Two, should become the rule rather the exception in CF's overseas interventions; weather or not CF should remain the "force of last resort" at home or take on new, non-traditional and proactive tasks.

Hugh Thorburn of Queen's University, for example, argues that special operations present advantages for Canada: it is less difficult to set up special operations forces than to (re)build large-scale militaries and it is more economical and expeditious to work with them. ${ }^{296}$ Paul de B. Taillon goes one step further, discussing the need for Canada to develop covert operations forces and capabilities (SOF acting in clandestine manner in foreign countries) that would perform duties similar to the ones assigned to Joint Task Force Two in post-9/11 Afghanistan, in the Haiti political crisis of March $2004^{297}$ and in the alleged military intervention to rescue two Canadian hostages in Iraq in $2006 .^{298}$ Deputy Minister of National Defence Ward Elcock agreed as well with the idea that JTF2-like capabilities were necessary assets in counter-terrorism efforts. ${ }^{299}$

\footnotetext{
${ }^{295}$ Dave Pugliese, "Missile shield could use our money, land," Ottawa Citizen, Dec. 3, 2004.

${ }^{296}$ Cited in: David Last et al., "Evaluating National Security in the Context of Terrorism: What Do Our Leaders Expect of Us?," paper presented at the Third War Studies Symposium Global Insurgency, Terrorism and Special Operations in the $21^{\text {st }}$ Century, organized by the Royal Military College of Canada and the Joint Special Operations University (USA), Kingston, ON, October 20, 2004.

${ }^{297}$ Paul de B. Taillon, "The Evolving Requirements of the Canadian SOF," paper presented at the Third War Studies Symposium Global Insurgency, Terrorism and Special Operations in the $21^{\text {st }}$ Century, organized by the Royal Military College of Canada and the Joint Special Operations University (USA), Kingston, ON, October 20, 2004.

${ }^{298}$ Peter Goodspeed and Stewart Bell, "Involvement of Canadian Agencies Unclear," National Post, March 24,2006 .

${ }^{299}$ Ward Elcock, "The Future Threat Environment," paper presented at the Third War Studies Symposium Global Insurgency, Terrorism and Special Operations in the $21^{\text {st }}$ Century, organized by the Royal Military College of Canada and the Joint Special Operations University (USA), Kingston, ON, October 20, 2004.
} 
Although acknowledging that special operations forces are very useful in the "war on terror," Maj.-Gen. Andrew Leslie pointed out, nevertheless, that they are highly secretive and they cannot help with many of the tasks Canadian Forces perform in theatres of operations around the world (such as maintaining the rule of law, making arrests, performing humanitarian tasks or assisting local authorities); he argues that conventional forces can be successfully employed in the new type of military interventions. ${ }^{300}$ What Maj.-Gen. (ret'd) Lewis MacKenzie proposes instead for the future Canadian Forces are specialized brigades focusing on rapid reaction operations, enforcement and homeland security. ${ }^{301}$ Divergent viewpoints on implementing the process of military transformation, expressed by policy makers and armed forces personnel, often indicative of civil-military tension, will be presented in the next chapter of this thesis.

\section{IV.3.d. Canada-United States defence relations}

A key feature of Canada's post-9/11 policy documents concerns the country's defence relations with the United States. The Defence Policy Statement, for instance, emphasizes that "[t]he United States remains Canada's most important ally"302 - for almost 70 years, the Canada-US defence relationship has been successful and mutually advantageous. Canadian and US soldiers have defended the joint interests of their countries in the

\footnotetext{
${ }^{300}$ Maj.-Gen. Andrew Leslie, "Conventional Forces Doing Special Things: Afghanistan and Lessons for the Future," paper presented at the Third War Studies Symposium Global Insurgency, Terrorism and Special Operations in the $21^{\text {st }}$ Century, organized by the Royal Military College of Canada and the Joint Special Operations University (USA), Kingston, ON, October 20, 2004.

${ }^{301}$ Maj.-Gen. (ret'd) Lewis MacKenzie, "Security and Defence," keynote address delivered at the Seventh Annual Graduate Student Symposium Security and Defence: National and International Issues, organized by the Conference of Defence Associations Institute and the Canadian Defence and Foreign Affairs Institute, Kingston, ON, October 29, 2004.

${ }^{302}$ Department of National Defence, Defence Policy Statement, 21.
} 
Second World War, the Korean War, the First Gulf War, military operations in the Balkans and post-9/11 interventions against terrorist and insurgent groups, based on shared values and - generally - a common understanding of the evolving international threat environment. Even when the two countries have had different priorities in terms of specific overseas military engagements, they have largely shared the same underlying values regarding foreign intervention. During the post-Cold War period, both countries have engaged in elaborate debates over the nature of threats and appropriate responses to the new challenges.

While the answers sought were not consistently clear - given the amorphous nature of the post-Cold War security environment and differences in the nature of their respective domestic political debates - Canada and the United States have worked together in peacekeeping and humanitarian operations, and in addressing problems associated with failed and failing states, terrorism and the proliferation of weapons of mass destruction. Homeland defence regained its importance for the United States in the 1990s, with a series of domestic terrorist attacks, although the role of US or - even less so - Canadian forces in a response to this new threat was less than obvious at that moment. Both countries deployed significant numbers of troops to Afghanistan, although Canada refused to participate in the US-led invasion of Iraq. Norman Hillmer lists as two possible explanations for this decision Canadian wariness about US President George W. Bush and differences between the two governments" "conceptions of global order. Iraq is 
Bush's war, just as Vietnam was Lydon Johnson's. Canada avoided both, and Washington's wrath was palpable."303

The two countries (or agencies within their governments) seemed interested in initiating discussions over a US-funded National Missile Defense system for North America. Some critics have raised concerns, however, over the possibility of Canada's participation in future military confrontations with the United States' adversaries and in space warfare. After expressing, in 2003-2004, its desire to join the US missile defence program, the Liberal Government announced in 2005 that Canada would not take part in the NMD system, a decision confirmed in 2006 by the country's Conservative Government.

Critics of this decision denounced the apparent inconsistency in political positions, arguing that it had been the very same Liberal leadership that had promoted the idea of joining the United States' missile defence program. In 2003, Minister of National Defence John McCallum had announced in the House of Commons that Canada would enter negotiations with the USA on this topic: "if we [Canada] are not inside the tent our ability to influence the US decisions in these areas is likely to be precisely zero." 304 Prime Minister Paul Martin had shared the same view, the House of Commons had passed a motion supporting "any system developed to defend North America against ballistic missiles" and, in August 2004, Minister of National Defence Bill Graham and Minister of Foreign Affairs Pierre Pettigrew announced that Canada amended the NORAD

\footnotetext{
${ }^{303}$ Norman Hillmer, "Reflections on the unequal border," International Journal, vol. 60, issue 2 (Spring $2005), 338$.

${ }^{304}$ James Fergusson, "Shall We Dance? The Missile Defence Decision, NORAD Renewal, and the Future of Canada-US Defence Relations," Canadian Military Journal, vol. 6, no. 2 (Summer 2005), 18.
} 
agreement with the United States, authorizing the Command "to make its missile warning function [...] available to the U.S. commands conducting ballistic missile defence." The implications of this episode for civil-military relations will be discussed in Chapter V of this thesis. ${ }^{305}$

The announcement that Canada would not take part in the NMD system raised concerns among Canadian defence experts that - following the 2002 reconfiguration of the United States' Unified Command Plan (UCP), through the creation of a US Northern Command (NorthCom) and the merger of the US Space Command (SpaceCom) with the US Strategic Command (StratCom) - Canada would be barred from key decisions on missile defence and from access to space surveillance data. The relevance of the bilateral North American Aerospace Defence Command was questioned, yet a 2006 Canada-US agreement extended its competencies in the area of maritime surveillance.

Despite this latter move, critics such as Christopher M. Sands, Senior Associate with the Centre for Strategic and International Studies in Washington, D.C., believe "NORAD could disappear"; even more moderate voices would argue that the 2005 decision is "a big departure" from previous tradition. David J. Bercuson of the University of Calgary sees it as "a big break" in Canada-US defence relations: "[a]nytime we have had a major evolution in the North American defence policy since 1940, the two countries have been together. ${ }^{306}$ Experts fear that NORAD would become an empty shell and substantive

\footnotetext{
${ }^{305}$ Department of National Defence, Canada and United States Amend NORAD Agreement, http://www.dnd.ca/site/Newsroom/view_news_e.asp?id=1422, August 5, 2004 (accessed September 10, 2004).

${ }^{306}$ Clifford Krauss, "NORAD in Jeopardy: Experts," National Post, February 28, 2005.
} 
decisions related to the defence of North America will be made by the United States with no input from Canada. Joseph T. Jockel and Joel J. Sokolsky pointed out that US NorthCom "is unhappy with the division of responsibilities between it and NORAD" and "sees Canada [Command], with its fairly broad mandate for military operations in the defence of Canada and its approaches (including the US), as its natural partner for transboundary cooperation.

Alongside the United States and separately, Canada has taken measures to increase the security of North America in the post-9/11 threat environment. As Joel J. Sokolsky noted, "in a number of significant respects, the government of Canada, in seeking to reassure Americans that their security is not threatened from the north, has also moved quickly and effectively to secure the Canadian homeland. ${ }^{, 308}$ But work on joint Canadian-US security and defence missions has increasingly taken place overseas. The Canadian Forces' Operation APOLLO and the Canadian participation in US-led Operation ENDURING FREEDOM and NATO-led ISAF have constituted solid efforts in trying to root out the Taliban and al-Qaeda elements and to strengthen the capacity of the Afghan state - by operating alongside US and allied forces. They proved, once again, as Foreign Minister John Manley pointed out, that "[t]here are perhaps no two militaries that are more interoperable than those of Canada and the U.S." ${ }^{309}$ 2001-2006 was a period in which this axiom proved largely to hold true, despite the fact that policy makers in the

\footnotetext{
${ }^{307}$ Joseph T. Jockel and Joel J. Sokolsky, "Renewing NORAD - Now if not forever," Policy Options, JulyAugust 2006, pp. 54-55.

308 Joel J. Sokolsky, "Northern exposure? American homeland security and Canada," International Journal, vol. 60, issue 1 (Winter 2004/2005), 36.

${ }^{309}$ Cited in: James Fergusson, "Shall We Dance?," 24.
} 
two capitals did not always share a common set of policy priorities ${ }^{310}$ or devise similar responses to the new threat environment.

\section{IV.3.e. Military responses}

Following the events of September 11, 2001, Canada engaged actively in tackling new security challenges. Alongside other measures, the country's military contribution to the "war on terror" was substantial: at home, in North America but mostly overseas, the Canadian Forces proved their capacity to respond forcefully to the post-9/11 security environment. However, some of these responses were mired in controversy and heated debates occurred over the optimal way of employing armed forces in the battle against such elusive entities as terrorist organizations and insurgent groups.

Given the nature of the new security environment, greater emphasis was placed on the defence of Canada and the protection of the North American continent than in the past. In just a few months following the 9/11 attacks, Canada passed legislation allowing lawenforcing agencies to "crack down" on radical organizations and individuals, and it created new organizations to deal with the new threat situation. Canada's Defence Policy Statement (2005) would become a blueprint for the Canadian Forces' transformation, proposing inter alia the establishment of Canada Command, supposed to enable the military "to bring the best available military resources from across Canada to bear on a

\footnotetext{
${ }^{310}$ On the United States' changing security priorities post-9/11, including a move from an initial strategy of primacy to broader objectives in US foreign policy, see: Elinor Sloan, "Beyond primacy: American strategy in the post-September 11 era," International Journal, vol. 58, issue 2 (Spring 2003).
} 
crisis or threat, wherever it occurs, nation-wide." 311 In the North American context, Canada and the United States initiated a series of bilateral mechanisms, such as the Smart Border Declaration of December 2001 and a Bi-National Planning Group (operational 2001-2006), meant to strengthen cooperation between the two neighbours on terrorismrelated issues.

An area of even greater cooperation was the Canada-United States joint participation in overseas military engagements. Shortly after 9/11, Canada deployed thousands of military personnel, 20 Canadian warships and a significant number of aircraft in operations in Afghanistan, the Arabian Sea and the Persian Gulf. ${ }^{312}$ The Canadian Forces also participated in several Proliferation Security Initiative (PSI) exercises and the Canadian Government repeatedly underscored that PSI "is a powerful response to the commitment that [Canada and its international partners] have made to address the proliferation challenge." $" 313$ In February 2002 the first major contingent of Canadian troops (about 850 soldiers from the Third Battalion of the Princess Patricia's Canadian Light Infantry Battle Group) was sent to Kandahar, as part of US-led Operation ENDURING FREEDOM, after a small group of JTF2 soldiers had reportedly taken part in reconnaissance, surveillance and combat missions in the region. Afghanistan would become, from the early stages of Canada's military presence there, the main focus of its overseas security interventions.

311 ***, "Backgrounder: Canada Command," http://www.forces.gc.ca/site/Newsroom/view news_e.asp?id=1692, June 28, 2005 (accessed March 14, 2006).

312 ***, "Canada's Fight against Terror," http://www.canadianally.com/ca/terror/terror military-en.asp, February 3, 2006 (accessed March 14, 2006).

${ }^{313}$ James Wright, "The Proliferation Security Initiative," remarks to the Proliferation Security Initiative Operational Experts Working Group Meeting, Ottawa, April 16, 2004, http://www.dfaitmaeci.gc.ca/arms/psi3-en.asp (accessed March 15, 2006). 
Canada is not an island, Prime Minister Stephen Harper said in 2006; five years after 9/11, he explained to his fellow Canadians the reasoning behind the presence of CF troops in Afghanistan: "to deal with the source of the 9/11 terror and to end, once and for all, the brutal regime that horribly mistreated its own people while coddling terrorists." ${ }^{\text {,314 }}$ Mr. Harper argued that the coalition forces in Afghanistan deny terrorist organizations the ability to use the country as a safe haven and also contribute to Afghanistan' reconstruction efforts. However, in order to provide significant forces on the ground, Canada's Conservative Government reduced its military commitments elsewhere in the world - e.g., withdrawing, in 2006, all its troops serving with the UN-led Golan Heights peacekeeping mission.

Between August 2003 and October 2005, as part of Operation ATHENA, Canada's contribution to the UN-authorized, NATO-led International Security Assistance Force, thousands of Canadian troops rotated through Kabul with the mission to contribute to creating a more secure environment in the Afghan capital. The CF personnel in Kabul performed a series of tasks usually associated with police forces and other non-military organizations: they fought against organized crime, patrolled main streets and provided advice to the Afghan Transitional Authority (ATA) on security and defence issues, and on the operation of the Kabul International Airport. According to the Department of National Defence, the overarching goal of the mission was "to prevent Afghanistan from

314 ***, “The Right Note," Maclean's, September 25, 2006, 17. 
relapsing into a failed state that provides a safe haven for terrorists and terrorist organizations. 9315

In 2006, over 2,000 Canadian Forces personnel were deployed to Kandahar as part of Operation ARCHER, in what would become the country's largest military deployment and its most dangerous mission since the Korean War. While both Liberal and Conservative leaders emphasized its critical importance in responding to the post-9/11 international treat environment and promoting Canadian values abroad, critics of this deployment accused the Government of hiding from the general public the nature of this mission. Among others, they pointed to the fact that neither the Government nor the Canadian Forces' senior staff shed sufficient light on a campaign that conducted a growing number of combat missions, often under direct US command, against Taliban and al-Qaeda elements.

Moreover, critics such as Colin Kenny, Chair of the Senate Standing Committee on National Security and Defence, started asking tough questions in relation to this deployment: "one has to wonder whether the cost is going to be worth the gain. Is there any strategy in place that will get us where we want to go? I wish I had an answer to that. So far I haven't seen one." ${ }^{\$ 16}$ Other security and defence analysts pointed to the apparent lack of an "exit strategy" on the part of the Canadian Government and conflicting positions on the nature of the mission and its expected duration. This intensified after

$315 * * *$, "Operation ATHENA: The Canadian Forces Participation in ISAF," http://www.forces.gc.ca/site/Newsroom/view_news_e.asp?id=1228, August 27, 2004 (accessed November $3,2004)$.

${ }^{316}$ Colin Kenny, "Rebuilding a country," Ottawa Citizen, June 10, 2005. 
media reports about Defence Minister Bill Graham "acknowledg[ing] that mending fences with the [United States] played a role in the government's decision to take on the Kandahar mission.

The Martin government embraced the idea of having Canadian troops in Afghanistan for a significant period of time, as the Canadian involvement in this theatre was based on the country's new "3D" approach. In the words of a Canadian official, "[it is] not just about having a bunch of troops on the ground. It is [about] going in there with the complete package: diplomacy, development and defence. This is right up our alley."318 This "complete package" materialized, among others, in the deployment, and strong support for, a Provincial Reconstruction Team in Kandahar. The Harper government would largely abandon the official use of the "3D" approach; despite strong support for diplomacy and development, the activity of PRT teams would be negatively affected by the deteriorating security situation in many areas of Afghanistan. The $\$ 3.5$ billion announced by the Conservative Government in 2006 for the Afghan effort focused increasingly on combat operations in the face of growing insurgent attacks on Canadian troops stationed in southern Afghanistan.

Added to this complex situation was the increasingly significant use of special operations forces by Canada in foreign theatres of operations and related speeches by top military leaders on the new combat focus of the Canadian Forces. "We are the Canadian Forces and our job is to be able to kill people," Chief of the Defence Staff Gen. Rick Hillier was

\footnotetext{
${ }^{317}$ David Pugliese, "From peacekeepers to Taliban hunters," Ottawa Citizen, March 25, 2006.

${ }^{318}$ Sheldon Alberts, "Canada set to beef up Afghan presence," National Post, Nov. 24, 2004.
} 
quoted as saying in 2005 , leading to angry responses from some politicians and members of the public. ${ }^{319}$ This did not prevent, however, JTF2 troops in Afghanistan from carrying out special operations, the pace of which increased after the Canadian mission's move to Kandahar in early 2006.

The lack of public debate prior to Canada's decision to move its troops to Kandahar and to alter the nature of its operations in Afghanistan raised concerns about the reasoning behind this choice and the end goal of the mission. As one Canadian diplomat put it, in early 2006 , "[w]e have turned a failed state into a fragile state $[\ldots]$ but there is no shared road map, ${ }^{, 320}$ a view underscored by the mixed mandate of Canadian operations there. Inter alia, critics argued that the measures taken by Canada in response to the new threats were uneven and that, in many cases, no solid argumentation was provided for specific decisions made.

Other critics argued that, given the frail chance of turning Afghanistan to stability and prosperity, the Canadian Government put its soldiers in harm's way for no other reason than to improve its relations with the United States. In many quarters, the uproar relating to Canada's decision not to participate in the US NMD system or to support a US-led invasion of Iraq was not about the Government responding inadequately to the new threat environment, but rather upsetting its relations with its southern neighbour. These debates would only intensify in the years following the 2001-2006 period, covered by this study.

319 ***, "Canada says to hunt down al-Qaeda in Afghnistan," Reuters, July 15, 2005.

${ }^{320}$ Hamida Ghafour, "Escalating violence has roots beyond Taliban," The Globe and Mail, January 17, 2006. 


\begin{abstract}
What the post-9/11 developments in the area of Canadian military affairs seem to indicate is a clear departure from the previous, post-Cold War status quo. Higher levels of defence spending, radically altered government policies, a sustained effort to transform organizationally and doctrinally the Canadian Forces, the country's repositioning vis-àvis the United States and an aggressive military intervention overseas, in Afghanistan all provide evidence for the idea of a thorough re-conceptualization of defence matters in post-9/11 Canada. This phenomenon is closely inter-related with, and has clear consequences for, the state of Canadian civil-military relations. Chapter $\mathrm{V}$ of this thesis will examine its implications for the interaction between the country's civilian and military leadership, against the backdrop of a new threat environment. The following section will provide a similar analysis of these factors in a different national context, Romania.
\end{abstract}

\title{
IV.4. Case study: Romania
}

IV.4.a. Defence background

The year 1989 marked a new beginning for Romania: the country left behind an authoritarian political system, a planned economy and a Communist identity. It engaged in a complex and painful transition process toward democracy, capitalism and integration 
into Western structures - fundamentally adjusting, along the way, the country's social fabric, its national identity, its institutional architecture and its relations with the rest of the world. In less than two decades following that annus mirabilis of global affairs, Romania has managed to accede to the European Union and to become a member of the North Atlantic Treaty Organization. Throughout this time, the military has been, alongside the Romanian Orthodox Church, one of the two most trusted institutions in the country. ${ }^{321}$

Nonetheless, despite this enviable position, the armed forces have been plagued by systemic problems and have been mired in political controversies. Given what was perceived to be an international security environment defined my much fewer and less significant threats, the Romanian military underwent a radical process of downsizing. It was supported by most political forces in Romania, at a time in the country's history when its limited financial resources had to be primarily directed toward social and economic restructuring programs. Many military leaders have occasionally opposed this process; some have even attempted to participate actively in political debates - either individually or in a collective form.

From about 250,000 military personnel in 1989 (most of whom were conscripted soldiers), the Romanian armed forces were downsized to about 100,000 in late 2006 (the majority being military employees). At the same time, from virtually no active military operations in 1989, the Romanian armed forces would participate in an increasing

${ }^{321}$ Interview with Serban Cioculescu (Researcher, Monitor strategic), by the author, Bucharest, Romania, April 18, 2005. 
number of international interventions, under the flags of the $\mathbf{U N}$, the Organization for Security and Cooperation in Europe (OSCE), NATO and multinational coalitions. Romania sent support troops to Saudi Arabia during the Persian Gulf War (1991), Somalia (1993-1994), Angola (1995-1997) and Bosnia-Herzegovina (1996-2001). It also sent peacekeeping and humanitarian assistance forces to Angola (1995-1997), Albania (1997-1999), Kosovo (after 2001) and Bosnia-Herzegovina (after 2001). It was, however, following the events of September 11, 2001, that Romania started to send troops in a predominantly combat role to foreign theatres of operations - up to 2,000 military personnel at a given moment as part of US- and NATO-led operations in Afghanistan and Iraq.

Most analysts agree that - combined with achievements in security and defence-related domestic reforms - Romania's active participation in the "war of terror" was a key contributing factor to receiving the invitation to join NATO in 2004. As George Cristian Maior, State Secretary for Euro-Atlantic Integration and Defence Policy at MApN, pointed out in 2004, "Romania's new strategic identity is being consolidated [...] through the intellectual ability to use 'windows of opportunity' created by a mix of domestic transformational dynamics and changes in the international security environment. ${ }^{\text {"322 In }}$ the first half of the 1990s this meant for Romania - externally - abandoning an already derelict military structure, the Warsaw Treaty Organization, and - domestically initiating the transformation of a military organization that was too large and redundant.

${ }^{322}$ George Maior, "Transformarea politicii de aparare a Romaniei: Trei teme de reflectie strategica," ISPAIM Occasional Papers (Bucharest), no. 5 (III)/2004, 3. 
A new legal framework was put in place for the functioning of its armed forces, new guidelines were agreed for military downsizing and a novel project started to take shape: closer relations, even interoperability, with NATO structures. There was strong opposition, however, from various military quarters to all these ideas - many military officers saw their vested interests threatened, but they were at the same time reluctant to support a large-scale restructuring program conceived and run by inexperienced, or even incompetent, civilians. In all Eastern European countries at the time, as Chris Donnelly explains, “[t]his was exacerbated by the militaries' lack of exposure to alternative professional views and by the naturally cohesive qualities found in all effective military systems. ${ }^{323}$

The process of transformation of the defence sector eventually led, in 1994, to the appointment of the first civilian Minister of National Defence, Gheorghe Tinca, and the signing of a framework document for stronger relations with the North Atlantic Treaty Organization - NATO's Partnership for Peace (PfP). The main objective of this restructuring process was, in the words of Lt.-Gen. Dumitru Cioflina, Secretary of State and Chief of the General Staff, to "establish smaller and highly mobile military forces, with modern training and equipment, under the democratic control of civil society. ${ }^{, 324}$

Given its laggardness in implementing systemic (including security and defence-related) reforms as compared with some of its neighbours in Eastern Europe, Romania was not

${ }^{323}$ Chris Donnelly, "Reform realities," NATO Review, vol. 49, no. 3 (Autumn 2001), http://www.nato.int/docu/review/2001/0103-11.htm (accessed July 12, 2006).

${ }^{324}$ Lt.-Gen. Dumitru Cioflina, "Restructuring and Modernizing the Romanian Armed Forces," NATO Review, vol. 42, no. 4 (August 1994), http://www.nato.int/docu/review/1994/9404-8.htm (accessed July 12, 2006). 
invited to join NATO at the Alliance's 1997 “enlargement" summit in Madrid. Romania had implemented only reluctantly embargo measures imposed by the international community against the government of former Yugoslavia and had sent mixed signals about its firm desire to choose sides in what was still perceived at the time as a "Cold War Light." The Romanian armed forces were still dominated by a generation of people that had been indoctrinated prior to 1989 (and, occasionally, after 1989 as well) against both the Soviet Union/Russia and the West.

To add to this situation, the transformation of the Romanian military - translated largely in downsizing and budget cuts - led to significant tension between civilian and military decision makers. Moreover, as Chris Donnelly explains, efforts to reform the armed forces from below failed as well, "either because [young officers] could not overcome the inertia of the mid-level structures or because they were undermined by superiors who viewed them as a threat." ${ }^{325}$ Toward the late 1990s, however, Romania seemed to have identified joining NATO and, eventually, the European Union as its top foreign policy objectives. The "NATO factor" started to play an increasingly important role in advancing noticeably the transformation of the Romanian military and the country's system of civil-military relations.

Yet, as Gen. Mihail Popescu would recognize toward the end of his term as Chief of the General Staff, "despite all efforts and measures undertaken - given decision-making disfunctionalities at the level of [both] the civilian and military leadership - in late 2000

${ }^{325}$ Chris Donnelly, "Reform realities." 
the credibility of military reform reached a critical stage. ${ }^{\text {} 326}$ With NATO accession and EU membership still a distant prospect, Romania continued to announce its willingness to take on new international security responsibilities, while lagging behind in terms of its domestic defence sector reforms. Given limited financial resources to fund the increasingly busy Romanian armed forces, military officers continued to be laid off by the thousands.

Whereas top-level officers were over-represented in the Romanian military (in many cases the Government sought vigorously to terminate their employment), the armed forces lacked enough personnel to fill mid-level officer positions. The military continued to hold a positive image among Romanians, but young people were generally reluctant about a career in the armed forces. The military budget fluctuated around 2 percent of GDP, a figure considered sufficiently high by many politicians and too low by most military leaders. As part of the Membership Action Plan (MAP), launched by NATO at its 1999 Washington summit to assist candidate countries, Romania took part in military exercises alongside its NATO partners and attempted to improve its domestic record relating to institutional reform, policy revision and improved civil-military relations.

It was 9/11 that gave the country's chances to NATO membership a significant boost: at a time when the United States initiated a war against international terrorism, countries such as Romania saw the opportunity to join the USA and its NATO partners in this global fight. The budget allocated to the Romanian military and to other security

\footnotetext{
${ }^{326}$ Gen. Mihail Popescu, "Starea Armatei Romaniei: Reforma si Integrare," http://www.mapn.ro, October 25, 2004 (accessed December 20, 2004).
} 
organizations rose following the events of September 11, 2001, and the Government's decision to send troops to Afghanistan and, later, Iraq - the military was promised a minimum level of 2.38 percent of GDP in a context of vigorous economic growth nationally. ${ }^{327}$ The prospect of receiving strong support from the United States for its NATO membership application, coupled with progress already made on transforming its armed forces, led to an accelerated pace of defence reform. In a 2007 interview, Prime Minister Calin Popescu Tariceanu commented on what the Romanian Government perceived to be a positive correlation between military involvement abroad alongside NATO allies, improved international relations and a higher pace of defence transformation domestically: "[t]oday, we increasingly see military diplomacy as an extraordinarily important instrument in the [Defence] Ministry's and the [Defence] Minister's activity. ${ }^{328}$

The North Atlantic Treaty Organization's decision at its 2002 Prague summit to invite Romania and other six Eastern European countries to join the Alliance was received enthusiastically in the country, although both civilian and military leaders understood that NATO membership would also mean greater security obligations for Romania internationally. This translated into much greater numbers of troops being deployed to foreign theatres of operations as compared with the pre-9/11 period and much higher portions of the defence budget allocated to external missions - a situation that would come to de described by top military officers, including Chief of the General Staff Gen.

${ }^{327}$ Guvernul Romaniei, Carta Alba a Securitatii si Apararii Nationale (Bucharest: Guvernul Romaniei, 2004), 43.

${ }^{328}$ Interview with Calin Popescu Tariceanu (Prime Minister of Romania), "Intarirea credibilitatii armatei," Observatorul militar, no. 14/2007 (April 12-17), 3. 
Eugen Badalan, as unsustainable. ${ }^{329}$ The Government's argument was that such changes were accelerated and made even more imperative by the security realities following 9/11.

\section{IV.4.b. Government policies}

From a Romanian point of view, the events of September 11, 2001 - tragic as they were triggered two sets of distinct, but closely interrelated, official positions. First, there was the reaction to what was perceived to be a different international threat environment; the need to adjust policies, reposition institutions and set up novel mechanisms to deal with the new security context has led to changes in all these areas. Second, there was in Romania - as in many other Western countries - the sense of an opening window of opportunity; the ability to use instrumentally the newly discovered international fight against global terrorism to forge closer relations with NATO and the United States was seen as a positive side effect of an otherwise tragic act.

As Minister of National Defence Ioan Mircea Pascu pointed out in 2003, the security environment changed to such an extent that "security has become a indivisible good of all and has to be defended everywhere it comes under threat." Nonetheless, he continued, the deployment of Romanian troops to fight terrorism in Afghanistan "eased [Romania's] efforts toward becoming a member of NATO" - by contributing forces to the US-led

\footnotetext{
${ }^{329}$ Bogdan Costache, "Armata nu are bani de NATO," Adevarul, October 14, 2005.
} 
"war on terror," Romania managed to secure its accession to the North Atlantic Treaty Organization and thus "contributed to strengthening its own national security.",330

A year later, in 2004, George Cristian Maior, State Secretary for Euro-Atlantic Integration and Defence Policy, expressed in an academic article one of the fundamental ideas to be found in all of Romania's post-9/11 major policy documents: the close interconnectedness between diplomacy and defence. Both dimensions, he argued, "gained a larger conceptual meaning" following the events of September 11, 2001: with the new international focus on combat operations against terrorist targets and the proliferation of weapons of mass destruction, but also on nation building, security now "involves an array of military, political, social and economic elements."331 ${ }^{93}$ Therefore, participation in military actions has obvious consequences for the diplomatic affairs of the countries involved, as political relations between them can also have a decisive impact on the way they conduct security operations.

One of the novel elements introduced by Romania's 2006 National Security Strategy (NSS) is the idea of proactive military intervention against global terrorism and WMD proliferation - an idea seen as controversial by some security analysts, but well received by the United States in the context of its "war on terror." "Through this Strategy, Romania enters a different stage of representing its own interests," President Traian Basescu said in early $2006 ; ;^{332}$ at that point, Romania already had more troops than any of

\footnotetext{
$330 * * *$, "Conferinta de presa," http://www.mapn.ro/briefing/030626/conferinta 030626.htm June 26, 2003 (accessed May 31, 2006).

${ }^{331}$ George Maior, "Transformarea politicii de aparare a Romaniei," 3.

${ }^{332}$ Doru Dragomir, "Pe doua limbi," ZIUA, April 18, 2006.
} 
its Eastern European partners in both Afghanistan and Iraq. The implications of its new policy orientation and the actors behind this process will be explored in more detail in the next chapter of this thesis. The following subsections will shed light on three of Romania's most important policy instruments during the 2001-2006 period: the 2006 "National Security Strategy," the 2004 "White Paper on Security and National Defence" and the 2001 "National Security Strategy of Romania."

\section{IV.4.b.i. 2006: The National Security Strategy}

Romania's 2006 NSS defined as the country's top security priorities the fight against global terrorism and transnational organized crime, the prevention of WMD proliferation, strengthening of failed and failing states, democracy consolidation and improved regional security and stability in South East Europe and the larger Black Sea region. "The main confrontation is [now] between fundamentally different values, between democracy and totalitarianism, determined by the major aggression of the international terrorism of an extremist-religious kind, structured in trans-border networks" - as a consequence, "terrorism cannot be ignored and cannot be tolerated," and "neutrality in the global war against terrorism is not possible." 333

Proactive and efficient counteraction against this threat was presented by Romania's 2006 National Security Strategy as the country's top priority concern, domestically and on the international stage. Yet, to tackle efficiently this threat, careful consideration

\footnotetext{
333 Presedintele Romaniei, Strategia de Securitate Nationala a Romaniei (Bucharest: Presedintele Romaniei, 2006), 7 and 14.
} 
should also be given to WMD counter-proliferation measures and to improving the political capacity of failed and failing states. Inter-ethnic and religious regional conflicts that "fuel $[\ldots]$ other forms of violence and facilitate terrorism activities" are also a grave source of concern, along with transnational organized crime - both of these phenomena are "emblematic of the [security] reality in [Romania's immediate] region."334

While all these trends and occurrences have been noted in previous post-9/11 documents, the key novelty brought about by the National Security Strategy was the idea of a proactive strategy in addressing the new threats. This includes military action against foreign targets, in Romania's near abroad, but also in other areas of the world. "Responsible and effective engagement in the international campaign against terrorism among others, through military means, whenever and wherever necessary - represents a major directive of Romania's security policy."335 The new policy guidelines would thus facilitate not only better counteraction against threats such as global terrorism and WMD proliferation, but also strengthening of political and security ties between Romania and other NATO member states, chief among them the United States.

As the first such document released after Romania's accession to the North Atlantic Treaty Organization in 2004, the 2006 NSS underscored the importance for this South East European country of belonging to a well-established military alliance. "The security guarantees enjoyed within NATO - expression of transatlantic solidarity - are the

\footnotetext{
${ }^{334}$ Ibid., 9 and 20.

${ }^{335}$ Ibid., 15.
} 
strongest in Romania's history. ${ }^{\$ 336}$ The consolidation of strategic partnerships, mainly with the United States, and contributions to the European Union's common foreign, security and defence policy are two other important policy objectives.

Despite its rather straightforward positioning vis-à-vis the post-9/11 international threat environment, the National Security Strategy was not without its critics. Most common among the points made by critics were the document's lack of specificity in defining the security challenges and the country's proposed responses, as well as the use of vague language and terminology in describing Romania's security objectives and the ways to achieve them. While some of these critical positions may be unwarranted - it is, after all, the bird's eye view that defines such a paper as a strategic document - it was noticeable that the 2006 NSS lacked clarity in a number of key areas. To quote Gen. (ret'd) Mihaiu Margarit, former head of Romania's Military Intelligence service, "there is frequent use [in NSS] of terms such as fundamental or vital national interests, formulated in a nonspecific and unclear manner." ${ }^{337}$

While strategic partnerships with the United States and other major partners were promoted - implicitly or explicitly - by NSS, the document did not go into significant detail in explaining Romania's links to the North Atlantic Treaty Organization and, especially, the European Union or the implications of advancing these partnerships for tactical, operational and strategic relations with NATO and EU partners. Even Prime Minister Calin Popescu Tariceanu said, shortly after the document's release, that the 2006

\footnotetext{
336 Ibid., 16.

${ }^{337}$ Gen. (ret'd) Mihaiu Margarit, “Strategia de securitate, un eseu,” Jurnalul national, March 9, 2006.
} 
NSS was not explicit enough in setting up a clear security agenda and in offering a identifiable roadmap of Romania's further integration into European and transatlantic security structures. ${ }^{338}$

\section{IV.4.b.ii. 2004: The White Paper on Security and National Defence}

According to Romania's White Paper on Security and National Defence, released in 2004 , the most significant international threats affecting the country were represented by terrorism, the proliferation of weapons of mass destruction and unstable and nondemocratic regimes. "The risks posed by the proliferation of terrorist networks, supported by organized crime and the illegal traffic of weapons," the White Paper pointed out, "require a coherent and comprehensive approach in the areas of prevention and counteraction of unconventional attacks against Romania and its allies." ${ }^{\text {,339 }}$ Similar to other policy documents issued by the Romanian government in recent years, the White Paper suffered from a lack of focus: while it covered convincingly general issues related to threats and risk factors, it seemed to use a poorly defined concept of security and to merely repeat most key arguments to be identified in previous documents.

Statements such as "approaching security from a purely military perspective is no longer sufficient" 340 and "states and societies are confronted today with the phenomenon of

\footnotetext{
${ }^{338}$ Doru Dragomir, "Pe doua limbi."

${ }^{339}$ Guvernul Romaniei, Carta Alba a Securitatii si Apararii Nationale, http://www.gov.ro, 2004 (accessed January 10,2005), 2.

${ }^{340}$ Ibid.
} 
globalization of risks" ${ }^{941}$ were not accompanied by more specific explanatory statements; they were too broad to be policy relevant. What the White Paper tried to offer was a basis for the Romanian Government's strategic thinking in an international and regional security environment defined by the wide proliferation of asymmetric threats and the expansion of the North Atlantic Treaty Organization in Central and Eastern Europe. It attempted to set broad guidelines on the future transformation of the Romanian armed forces, based on the country's security needs, political interests and financial constraints.

One of the novelties introduced by the White Paper was the concept of "defence diplomacy" - a public acknowledgement that the Romanian military tackles the country's security concerns, but also supports and promotes political goals (chief among the latter Romania's role within NATO and the strengthening of its strategic relationship with the United States). It is relevant in this context that the document' first chapter elaborated at length about the significance of Romania's membership in NATO and the European Union, its geo-political place in South East Europe and the larger Black Sea region and the need for conceptual and institutional military adaptation to a new security reality and different political objectives.

As the White Paper pointed out, "NATO integration and the transformation of the armed forces are two interdependent and essential elements of Romania's efforts to ensure national security. ${ }^{.342}$ To achieve these objectives, the document promoted the idea of a smaller, more flexible, more mobile, better equipped and NATO-interoperable military.

\footnotetext{
${ }^{341}$ Ibid., 3.
}

${ }^{342}$ Ibid., 13. 
The new forces could thus be asked to participate in allied interventions, including "highintensity military operations $[\ldots]$ away from the national territory and outside NATO's area of responsibility." ${ }^{.343}$ These changes would not only facilitate better integration of Romanian armed forces within NATO structures, they would also secure, if needed, NATO help against threats to Romania.

The proposed defence transformation strategy signalled a shift toward an expeditionary and increasingly proactive policy that was meant to address new global threats such as international terrorism, but also to create "a new strategic profile of Romania" ${ }^{344}$ and to solidify its political links to key NATO countries, such as the United States. These would prove to be, however, significant tasks and their implementation would lead to civilmilitary clashes (to be explored in Chapter V of this thesis). While Romania's intervention, alongside its NATO allies, in Afghanistan proved to be more strongly supported by both civilian and military leaders, the successive deployments of Romanian troops to Iraq grew increasingly controversial over the years.

IV.4.b.iii. 2001: The National Security Strategy of Romania

Endorsed by the Romanian Parliament only two months after 9/11, the 2001 National Security Strategy of Romania presented a similar picture of the threats to the country's security, but offered fewer policy prescriptions. According to this document, the "enlargement of the spectrum of unconventional risks [and] the diversification of the

\footnotetext{
${ }^{343}$ Ibid., 37.

${ }^{344}$ Ibid., 121.
} 
types of crises and conflicts have been generating multiple challenges that require multidirectional reactions, based on mobility, diversity, coherence and complementarity, both domestically and internationally. ${ }^{345}$ One of the key differences between this Strategy and other post-9/11 documents is a less precise definition (and possibly understanding) of the new security challenges.

While internally the threats to Romania's security and stability were defined as a series of difficulties in the political, social and economic realms, the document identified more violent threats in the external environment (among others, "irrational acts of forces pursuing terrorism as a means of dividing the international community and weakening world stability"). ${ }^{346}$ Yet its vague description of security challenges and its few directions of actions prescribed (among others, a general commitment to further Euro-Atlantic integration) made the 2001 National Security Strategy less useful as a policy paper than the documents succeeding it.

Despite some of their weaknesses, all of Romania's post-9/11 policy documents identified terrorism, the proliferation of weapons of mass destruction and failed and failing states as major challenges to international security and stability - alongside the strategic objective of joining the Atlantic Alliance. They underscored the country's

${ }^{345}$ Presedintele Romaniei, The National Security Strategy of Romania: Safeguarding Democracy and Fundamental Freedoms, Sustainable Economic and Social Development, and Integration into NATO and the European Union (Bucharest: Presedintele Romaniei, 2001), 7.

${ }^{346}$ Ibid., 6. 
determination to address these challenges; implicitly or explicitly, they also made clear the Romanian Government's understanding that the new threat environment offered the chance of strengthening relations with its international partners, by being on the same side in the fight against these novel threats. To materialize this latter desire, deep changes were necessary (and made) in relation to military structures and defence policies. The next subsection will explore this transformation course: the broad set of ideas behind it, developments in the transformation process and transformation challenges.

\section{IV.4.c. Defence transformation}

\section{IV.4.c.i. The idea of transformation}

The desire to transform the Romanian armed forces had been present - at both civilian and military levels - since the early to mid-1990s, although to different degrees. It intensified, among political and military leaders alike, following the events of September 11,2001 , a period in which (i) the need for defence-sector reform became evident in many countries around the world and (ii) Romania's chances to join Western security structures rose considerably. Both these factors contributed directly to pushing forward the radical makeover of the Romanian armed forces, based on (i) perceived pressures dictated by the new global threat environment and (ii) a perceived "window of opportunity" for Romania to prove to its Western partners - mainly the United States its willingness and ability to join them in the newly discovered "war on terror." 
The process of transformation of Romania's military establishment took off after 9/11, at a time when the North Atlantic Treaty Organization itself launched an overhaul of its political and military structures to better respond to the new international security context. Answering a reporter's question in April 2002, Chief of the General Staff Gen. Mihail Popescu said, "[not] the Americans tell us what to do, nor NATO, but Romania's needs. What we must have, given the security environment in which Romania finds itself, is not a military designed primarily to defend the country, but a military for security and collaboration. ${ }^{347}$ In other words: armed forces that can participate in a wide range of security operations, at home and abroad, that are highly interoperable with Romania's key international partners, notably the United States and the United Kingdom.

To be able not only to respond to new threats such as global terrorism, the proliferation of weapons of mass destruction and failed and failing states, but also to advance Romania's strategic interests, the military was subjected to a far-reaching process of transformation. In the words of Romanian President Ion Iliescu, post-9/11 military reform was guided by the idea of "flexible, rapidly deployable, self-sustainable professional forces, fully interoperable with NATO." ${ }^{348}$ Adapted to fighting terrorism and to assisting with the reconstruction of weak and collapsed polities, the Romanian armed forces were given new roles and were asked to perform missions that represented a radical departure from their traditional assignments.

\footnotetext{
347 ***, "Conferinta de presa a sefului Statului Major General," http://www.mapn.ro, April 22, 2002 (accessed June 10, 2006).

${ }^{348}$ Ion Iliescu, "Taking No Chances," Transitions On Line, http://www.tol.cz, November 21, 2002 (accessed November 21, 2002).
} 
As State Secretary for Euro-Atlantic Integration and Defence Policy George Cristian Maior pointed out, "[w]hat we're talking about here is, in fact, a conversion from the exclusive logic of territorial defence to the multifaceted logic of expeditionarism. In other words, the novel introduction of new variables [...] capacity of deployment and selfsustainability, mobility, agility, flexibility." ${ }^{349}$ Whereas during the Cold War the Romanian military had as its exclusive role the country's defence against a foreign (Soviet or Western) invasion, with no external support, the new armed forces are mainly designed to participate alongside Romania's allies in security operations far beyond the country's borders.

IV.4.c.ii. Developments in the transformation process

Despite some hurdles (to be explored later in this section and in the next chapter of this thesis), the transformation of the Romanian military moved forward, following the events of September 11, 2001, at a vigorous pace. The "Force-Objective 2007" proposed by the Government in the early 2000 s as a roadmap for military transformation was largely declared achieved by late 2006 (it would be followed by "Force-Objective 2012"). Its main goal focused on the creation of a new Romanian military, one that moves beyond territorial defence in a traditional sense and is able to participate alongside other forces in external security operations. For increased preparedness levels and improved interoperability with its Western allies, the Romanian military abandoned compulsory conscription and concluded its move toward professionalism by late 2006 .

\footnotetext{
${ }^{349}$ George Cristian Maior, "Transformarea politicii de aparare a Romaniei," 4.
} 
As Minister of National Defence Teodor Atanasiu pointed out, the transformation aimed, in broad terms, "at developing the institutional capacity and reviewing the administration structures and defence procurement" so that the military body becomes "more efficient and credible, to ensure the defence and promotion of Romania's vital interests." Annual defence expenditures were stabilized below 2 percent of GDP throughout this reform phase, which allowed the military to send troops abroad and maintain operational forces at home only by reducing its size (a discussion of civil-military tensions over defence spending levels will be provided in Chapter V).

The armed forces were re-structured, by concentrating military bases in fewer locations and increasing the forces' operational readiness; by relying less on territorial and reserve forces and more on the new category of "active forces;" by stressing the need for rapidreaction, expeditionary forces, ready to be send abroad for peacekeeping, humanitarian and combat operations; and by setting up special operations forces, consisting of army, navy and logistical components. Chief of the General Staff Gen. Eugen Badalan also proposed in 2005 the creation of a Romanian military intelligence battalion, to be completed in a few years, that would offer niche capabilities to future NATO operations. $^{351}$

All these developments were defined as priorities in the 2004 White Paper on Security and National Defence, which stated the need for forces that reflect Romania's new strategic approach in these areas: "surveillance and early warning; prevention and crisis

\footnotetext{
${ }^{350}$ Interview with Teodor Atanasiu, "An Army of Professionals," Romanian Military Newsletter, February 14, 2005.

${ }^{351}$ Radu Tudor, "Batalion romanesc de informatii militare," ZIUA, November 15, 2005.
} 
management; participation in countering terrorism; and collective defence missions."352 The central structure of the Romanian armed forces was also transformed, alongside the forces' territorial structures, in an attempt to create a more flexible and more efficient military. As a result of this process, by mid-2000s, Romania was able to send abroad over 2,000 troops at a given moment, a figure comparable with Canada's or other countries of a similar population size.

These changes have been based on re-structuring the armed forces along two lines: deployable forces and in-place forces. The traditional organization of the Romanian military for the collective defence of the country's territory has given way to expeditionary units, able to execute the entire range of NATO missions. ${ }^{353}$ In the new global war against terrorist and insurgent groups, the Romanian military broadened the scope of its actions from training for counter-terrorism responses domestically to deploying forces in places such as Afghanistan and Iraq. As a next step, Romania offered the North Atlantic Treaty Organization and its immediate allies a set of "niche capabilities" to be used in multinational operations, chief among them mountain troops and military intelligence units. Minister of National Defence Teodor Atanasiu indicated in 2005 that Romanian mountain troops were particularly useful in the rugged terrain of Afghanistan. ${ }^{354}$

${ }^{352}$ George Cristian Maior, introduction to Carta Alba a Securitatii si Apararii Nationale, 4.

${ }^{353}$ Interview with Gen. Mircea Muresan, by Col. Cosinel Petrache, "Structura de Forte 2007 va fi rezultatul nevoilor reale ale apararii nationale," Gandirea militara romaneasca, no. 3/2003, 142-143.

${ }^{354}$ Raluca Crisan, "Atuurile lui Teodor Atanasiu: vanatorii de munte si spionii," Evenimentul zilei, January $17,2005$. 
At home, the Romanian military and the Ministry of National Defence strove to improve its cooperation with the other departments and agencies that were part of the National System for the Prevention and Counteraction of Terrorism. Alongside better inter-agency coordination, a radical overhaul of the military organization was initiated by the Ministry of National Defence, based on the idea of an integrated multi-service operational command structure. Special operations forces have also been set up, able to carry out missions on Romania's territory and beyond.

While SOF units were active in Afghanistan, under US-command, starting in mid-2000s, the Romanian Government announced the creation of an SOF battalion, scheduled to be operational in $2007\left(1^{\text {st }}\right.$ Special Operations Battalion "Vulturii"/"Eagles"). The special operations forces were assisted in their operations by specialized military intelligence units and beefed-up navy and air force capabilities (a process begun in the 2001-2006 period and planned to intensify during the 2007-2012 period). Improved capabilities, revised military doctrines and specialized force structures were meant not only to better respond to a radically transformed international security environment, but also to offer Romania a better political position in the international arena - enhanced relations with its NATO partners, especially the United States, were propped up by sympathetic military support. 


\section{IV.4.c.iii. Transformation challenges}

Nonetheless, even if the idea of transformation was generally well embraced by both political and military leaders, the exact roadmap to reform the Romanian armed forces was a matter of wide-ranging debate. First, there was opposition to the idea of downsizing the Romanian military, coming from the groups and individuals directly affected: the military officers that would be laid off. Second, there were difficulties in the transformation process, such as controversial procurement programs, lack of transparency and a general sense of frustration on the military side with how the Government ran the various transformation programs. Third, there were civil-military differences over the pace of the transformation process and its technical aspects.

All these parallel, yet interconnected, debates occurred in a context in which Romania was engaged in an unprecedented effort whose end-goal was the systemic transformation of its political, economic and social systems that would eventually allow the country to join not only NATO, but also the European Union. As a consequence, questions related to new strategies and institutional changes to deal with a novel threat environment were often imprecisely formulated and the ensuing conversations hazy. As Mihail Popescu of the Bucharest-based Institute for Political Studies of Defence and Military History (ISPAIM) recalled, "military leaders started asking what is expected of the armed forces in a cooperative security context. What is the balance between the external and the internal focus for the military? Should the forces take on tasks such as fighting organized 
crime or maintain a more traditional stance?"355 Trying to use instrumentally an emerging world order to advance the country's strategic interests was difficult at best, in a context in which NATO itself engaged on a transformation path and - when the US-led attack on Iraq occurred in 2003 - trans-Atlantic security relations stalled. Civil-military conflict seemed to threaten any progress made on these previous issues.

Using the military as an instrument of diplomacy tended to complicate the process of armed forces transformation, as several sets of priorities seemed to be at play at once: not only a military that was being adapted to the twenty-first century security context and small enough that it could be supported by the country's limited national budget, but also an organization that advanced a broad range of foreign policy objectives. "[B]eyond the national security component," Romanian President Traian Basescu pointed out in 2004, "it is our goal that the military support Romania's foreign policy. [...] The more the military will be well equipped, strong and professional, the more our partnership with the United States and the United Kingdom will be continued, consolidated. ${ }^{.356}$ President Basescu also addressed the issue of the very large number of generals in the Romanian armed forces, stating his determination to gradually reduce their number, in both absolute and relative terms, throughout the process of downsizing the military establishment. ${ }^{357}$

At times, military leaders felt frustrated not only about uncertainty and the potential of losing their employment, but also about a perceived tendency on the part of politicians to

\footnotetext{
${ }^{355}$ Interview with Dr. Mihail Popescu (Director, Institute for Political Studies of Defence and Military History), by the author, Bucharest, Romania, April 18, 2005.

356 ***, "Alocutiunea Presedintelui Romaniei, domnul Traian Basescu," http://www.mapn.ro, December 29, 2004 (accessed February 11, 2005).

${ }^{357}$ Radu Tudor, "Prea multi generali," ZIUA, March 10, 2005.
} 
appropriate the positive outcomes of defence reform. As Minister of National Defence Ioan Mircea Pascu explained, using as an example the move toward a professional military, "much too often, we have an easy inclination in the political quarters [...] to pretend that all benefits arise from their proposals $[\ldots]$ compulsory conscription is simply no longer needed."358 Civil-military controversies related to the transformation of the Romanian armed forces will be assessed in Chapter V of this thesis. The next section will look at Romania-US defence relations and their significance in the context of a new and rapidly changing international threat environment.

\section{IV.4.d. Romania-United States defence relations}

Overwhelmingly since the end of the Cold War, the Romanian Government has emphasized the importance it attaches to its relationship with the United States. There is no other country that has received more positive attention in Romania during this period; in sizable sections of the Romanian population, this attitude goes back to the Cold War itself. Romania was the first former Eastern bloc country to join NATO's US-endorsed Partnership for Peace in 1994 and both President Bill Clinton and President George W. Bush visited Bucharest, in 1997 and 2002 respectively.

A report by the US Department of State suggested that President Clinton's visit was recognition of Romania's unequivocally pro-Western and pro-US policies; the two countries initiated and developed "cooperation on shared goals, including economic and political development, defense reform, and non-traditional threats (such as trans-border 358 ***, "Conferinta de presa la MApN," http://www.mapn.ro, June 26, 2003 (accessed July 3, 2004). 
crime and non-proliferation). ${ }^{, 359}$ Romania's pro-American approach comes as no surprise to seasoned analysts of the region, as - even prior to 1989 - the United States had inspired the population and had been seen more positively than the Soviet Union by the country's Communist leadership.

Following the revolutionary events of December 1989, Romania expressed its desire to join the North Atlantic Treaty Organization and the European Union, as well as to strengthen relations with the United States and other key international partners. Fear of Russian and - to a lesser extent - German domination in Europe provided additional reasons for Romania to pursue integration into the EU and NATO, and to advance the cause of strong transatlantic relations. As an editorial in The Romanian Digest put it eloquently in 2006, "[t]o see the world through the eyes of Romanians is to understand why over one hundred and thirty thousand Romanians wept in a rain-soaked Revolution Square $[\ldots]$ when they heard US President George W. Bush telling them that Romania need never again fear foreign domination." 360 This provides evidence for the idea of Romanian involvement in US-led missions being motivated not just by the necessity of tackling new international threats, but also by a perceived need to secure - in return - US security guarantees for the country. ${ }^{361}$

\footnotetext{
${ }^{359}$ United States Department of State, Background Note: Romania, http://www.state.gov/r/pa/ei/bgn/35722.htm, December 2005 (accessed June 5, 2006).

$360^{* * *}$, "Romania's National Security Dilemma," The Romanian Digest, vol. X, no. 9 (September 2005), http://www.hr.ro/digest/200509/digest.htm, September 2005 (accessed June 8, 2006).

${ }^{361}$ In both Romania and Canada, civilian and military leaders were largely in agreement about promoting closer defence ties with the United States; however, civilian leaders had to balance this objective against political considerations, as portions of their respective electorates opposed such ties.
} 
The two countries initiated a Strategic Partnership and set up a Bilateral Working Group in 1997; yet, prior to 9/11, Romania-US security and defence relations were limited to collaboration on military missions in the Western Balkans and other small-scale peacekeeping operations. Romania still focused most of its energy in this area inwards, making efforts to advance on the path of transforming its armed forces and its broader security apparatus. The importance of unyielding and lasting Romania-US relations was repeatedly underlined by the Romanian Government, yet it did not move much beyond declaratory status. This situation would change dramatically following the terrorist attacks against the USA on September 11,2001, and subsequent retaliatory action by the United States and its allies.

Romania joined the US-led "war on terror" from its early days: it immediately declared itself a "de facto NATO ally," it opened its air space, air fields and port facilities for military action against Afghanistan's Taliban regime only a few days after 9/11 and it sent its first troops to Afghanistan as early as January 2002. In 2003, it would also join the US-led war against Iraq, a move that was partly perceived - in Romania and elsewhere - as an attempt to consolidate its links with the United States, rather than a response to a genuine, immediate threat arising out of the Middle East. In early 2006, Romania concluded an agreement with the United States for the creation of several American military bases ("forward-operating sites") on Romanian territory.

Minister of National Defence Teodor Atanasiu argued that both political and military leaders were supportive of closer Romania-US relations (a similar position being 
expressed by his military counterparts): “[f]rom the Government's point of view, there is no reservation. From Parliament, it is okay. From the armed forces' point of view, there is no reservation. And from the population, there are no major issues. ${ }^{\text {362 }}$ The agreement to establish American bases in Romania was the first such deal to be signed by the United States with a former Eastern bloc country. Romanian troops started to train with American soldiers, to conduct joint military exercises at Black Sea coastal bases and to participate in multinational overseas operations, a development that seemed to advance both the Romanian Government's foreign policy objectives and the Romanian armed forces' aspiration for international visibility and better defence funding.

Yet the nature of Romania's newly found strategic partnership with the USA was questioned by a number of actors, at home and abroad, when The Washington Post run a story in late 2005 alleging that several Eastern European countries hosted secret CIA prisons post-9/11. The US-based NGO Human Rights Watch would eventually identify Romania and Poland as the most likely locations of such detention centres and the Council of Europe would start an official enquiry into the matter. When concluded, the Council of Europe investigation and a similar one, initiated by the Parliament of Romania in 2006, did not offer any solid proof to substantiate the claims; nonetheless, it opened up questions about Romanian political and military leaders' possible willingness to compromise democratic principles and the rule of law in the name of better relations with an external partner.

\footnotetext{
${ }^{362}$ Cited in: Russ Rizzo, "Romania moving closer to base access deal with U.S.," Stars and Stripes, July $25,2005$.
} 
Officials in Bucharest vehemently denied any involvement in this affair, while Romanian and foreign analysts questioned, in turn, the Government's eagerness to get to the bottom of this story. Political analyst Marian Chiriac saw it "unlikely that the current government would risk offending Washington by launching a [thorough] investigation that could confirm the existence of such prisons." ${ }^{363}$ Military officials generally avoided public involvement in this debate with transatlantic ramifications - this was not an issue generating civil-military friction; on the contrary, it seems to indicate harmony between politicians and armed forces personnel on a topic of common concern (to be explored further in Chapter V of this thesis).

President Traian Basescu visited the United States and met with US President George W. Bush several times after becoming President of Romania in late 2004. It was the concluding stage of a larger campaign by the Romanian Government for recognition in Washington as a steadfast ally of the USA, campaign initiated by Romania's leaders in the mid- to late 1990s. Romanian foreign policy analysts would promptly emphasize the historical relevance of these contacts: "[h]aving made itself useful to the United States, even to the sometime consternation of the French, the Germans and the Russians, Romania has obtained a modern security blanket that $[\ldots]$ can go a long way today in securing the nation's defence. ${ }^{364}$ Nonetheless, to convince the United States of Romania's commitment to the war against terrorist and insurgent groups, Romanian troops were deloyed in relatively large numbers in Afghanistan and Iraq and such

\footnotetext{
${ }^{363}$ Marian Chiriac, "Romania wary of probe into illegal prisons," Taiwan News, December 19, 2005.

364 ***, "Romania's National Security Dilemma."
} 
deployments would eventually generate heated exchanges among political and military leaders toward the end of the 2001-2006 period.

Some observers raised the issue of lack of an imminent threat to the country's security, some pointed to opposition on the part of several European countries to US military action in the Middle East and others emphasized the dramatic change in the country's military doctrines, as well as foreign and defence policies: Romania had never before sent military contingents for combat missions on other continents. "Our country will abide by the commitments assumed in Afghanistan and Iraq, for as long as it is necessary," President Traian Basescu stated in $2005^{365}$ - a position that would lead to significant civil-military tensions.

\section{IV.4.e. Military responses}

The intervention of Romanian troops in Afghanistan and Iraq constituted only one element, albeit the most significant and visible, of the set of measures taken by the Romanian Government in response to the changing security environment. New legislation was adopted to deal with was perceived to be the growing threat of international terrorism, proliferation of weapons of mass destruction, failed and failing states, and organized crime. New institutions were created to coordinate and improve inter-agency work and tackle the new security challenges to Romania's homeland; new bilateral and multi-lateral international agreements were concluded, to advance broad collaboration on security-related tasks.

${ }^{365}$ ***, "Press Communiqué," http://www.presidency.ro/, July 11, 2005 (accessed July 20, 2005). 
Not always, however, there was agreement over responses initiated in the context of this novel threat environment - from joint coordination structures for the intelligence services and increased integration within the country's security and defence apparatus to new security and defence policies and military doctrines, including new roles and missions for the armed forces. Greater emphasis was placed on the defence of Romania's national territory, the initiation and consolidation of bilateral security relations with key NATO partners, the transformation of the Romanian military and better interoperability with allied armed forces. Measures taken post-9/11 in security and defence areas consolidated Romania's image as a reliable international partner in the "war on terror," but raised questions at home related to the country's ability and willingness to sustain such a course of action in the medium and long term.

Shortly after the events of September 11, 2001, Romania's Supreme Council of National Defence adopted emergency measures to respond to the new situation created by the $9 / 11$ terrorist attacks. It opened the country's territory for the transit of multinational forces to participate in the US-led military intervention in Afghanistan (Operation ENDURING FREEDOM), it sent Romanian mountain troops to Kandahar and Kabul (Operation FINGAL - the first military deployment to Afghanistan by a NATO candidate country), it created an Operational Team to monitor terrorism-related developments and it urged the military to speed up its process of transformation. 
Romania thus "[a]dapted armed forces reforms to better fight against asymmetrical threats by planning a new force structure (endorsed by NATO) with emphasis on special operations, mountain troops, military intelligence, military police and other elite units." ${ }^{\text {366 }}$ Alongside its military deployment to Afghanistan, Romania linked its air control system to the Atlantic Alliance's NATINADS radar system, it sent liaison officers in the United States and the United Kingdom, it improved early warning and surveillance capabilities, it developed "increased intelligence capacities [...] reinforcing HUMINT resources" and it increased the activity of its "intelligence assets deployed with NATO operations in the Balkans [...] to monitor and detect possible terrorist actions in the region. 367

During the first half of the 2001-2006 period, Romania made considerable efforts to prove to its international partners its level of preparedness and motivation to participate in military operations away from its national territory. It pressed ahead with restructuring its armed forces, while deploying military contingents to Afghanistan and Iraq. State Secretary George Cristian Maior saw these developments as "a natural continuation of a position adopted [by Romania] at a political level as early as September [2001], in the wake of the tragic events of $9 / 11 . .368$ Romania was the first NATO candidate country in 2002-2003 to participate in missions in Afghanistan coordinated by the International Security Assistance Force.

\footnotetext{
${ }^{366}$ Government of Romania, Romania on its Way to NATO (Bucharest: Government of Romania, 2002), 202.

${ }^{267}$ Ibid., 203.

368 ***, "Conferinta de presa," http://www.mapn.ro, January 8, 2002 (accessed June 14, 2006).
} 
It was the first time Romania sent large numbers of troops for military operations on other continents and the first time in its modern history it launched military offensives against foreign troops pre-emptively. Unlike other governments around the world, Romania's Government was open in presenting its intervention in Afghanistan as warfare: "the dangers are significant, we cannot stress this aspect enough; we are talking in fact about combat missions, including the destruction of Taliban terrorist networks."369 To achieve this latter objective, the Romanian military employed novel technology (e.g., unmanned aerial vehicles) and improved its interoperability with NATO forces and the Afghan National Army.

Not everything ran without problems: the Romanian officers in charge of information operations (IO) conducted by ISAF in Afghanistan proved their relative inability to achieve specific IO objectives, ${ }^{370}$ the troops in Iraq were most often given a support role for other NATO forces given the Romanians' lack of experience in combat situations and - in both Afghanistan and Iraq - their dated equipment was at times a source of humiliating jokes and irritation for coalition partners. Nonetheless, during the second half of the 2001-2006 period, Romania was able to increase the number of its special operations forces in Afghanistan and to send an SOP-like military intelligence team to Iraq, which became models for the future transformation of Romanian expeditionary forces.

\footnotetext{
$369 * * *$, "Conferinta de presa," http://www.mapn.ro, August 21, 2002 (accessed June 20, 2006).

${ }^{370} 2^{\text {nd }}$ Lt. Jessica M. Davis, "From Kosovo to Afghanistan: Canada and Information Operations," Canadian Military Journal, vol. 6, no. 3 (Autumn 2005), 38.
} 
While the Romanian SOP teams in Afghanistan were reportedly engaged in "hunting down" Taliban insurgents and alleged al-Qaeda members, the intelligence teams in Iraq participated, alongside coalition forces, in gathering and processing human and electronic intelligence. Romania also announced its desire to contribute to the reconstruction efforts in the two countries, yet the vast majority of missions would continue to be of a predominantly military nature. While developments on the ground run generally smoothly - except for the death of several soldiers in the Afghan and Iraqi theatres - it was at home that analysts and political actors raised questions about the nature and appropriateness of Romania's military interventions overseas and where civil-military tensions started to flare up.

One of the key issues raised by pundits and politicians during this five-year period related to the Government's motives behind deploying large numbers of Romanian troops to the dangerous theatres of Afghanistan and Iraq. While most officials and commentators acknowledged the need for firm responses to a changing international security environment, including military action, many also questioned the extent to which such decisions were meant to improve political relations with external partners. Prior to becoming a NATO member state, in 2004, the Government was accused at times of sending Romanian troops in harm's way purely for the sake of joining the Atlantic Alliance - a premise invalidated by similar levels of troop deployments in the 2004-2006 phase. Nonetheless, as to confirm critics' suspicions, Minister of National Defence Ioan Mircea Pascu stated in 2002 that "the road to Prague went through Kandahar," a likely 
reference to the impact of the military contribution to the war-on-terror effort on NATO's decision to offer Romania membership status. ${ }^{371}$

President Traian Basescu would also explain in frank terms, in 2005, the significance of the Romanian armed forces' presence in Iraq: alongside their purely military role, "we use [them] in our foreign policy, as a tool to solve Romania's priority problems." 372 Former Romanian President Ion Iliescu reportedly asked his Chief of the General Staff, Gen. Mihail Popescu, and then-Minister of National Defence Ioan Mircea Pascu, in the early 2000s: "Gentlemen, is this the price [to pay for NATO membership]?" (the two agreed). ${ }^{373}$ According to Gen. Popescu and other observers, it was not only about assisting coalition countries in their military efforts, but also impressing NATO member states of Romania's ability to participate militarily in complex security operations. While not unusual for a country to use its armed forces to advance non-military goals internationally, these particular decisions led to vigorous debates, since they were radical enough to change the very nature of Romania's presence in the international arena and the traditional roles of the country's armed forces.

Maj.-Gen. Teodor Frunzeti argued in a 2005 interview that Romania's interventions in Afghanistan and Iraq had several main components: a security component, as a response to a new world order, a military component (the new missions represent "a very important professional experience" for the armed forces) and a political component

\footnotetext{
${ }^{371}$ Ioan Mircea Pascu, "Securitatea Romaniei se apara si la mare distanta de tara," Observatorul militar, no. 3 (January 21-27, 2004).

${ }^{372}$ Anca Hriban, "Basescu, vizita secreta in Irak si Afganistan," ZIUA, March 29, 2005.

${ }^{373}$ Interview with Gen. Mihail Popescu, by Col. Ion Petrescu, "Romania are, in Armata, un pilon de nadejde!," Observatorul militar, no. 42 (October 21-27, 2004).
} 
("Romania proves to be an ally and a credible partner for the United States" and other NATO member states). ${ }^{374}$ The intertwining of all these elements made policy prescription and decision making a difficult process, with various interest groups expressing contradictory views on an elusive best course of action. The clash between Romania's Minister of National Defence Teodor Atanasiu and Chief of the General Staff Gen. Eugen Badalan was evidence of this complex setting (to be explored at length in the next chapter).

Such contradictory views are indicative of the complex task of adjusting a country's security and defence establishment to the requirements of a new world order. Romania's civilian and military leadership engaged the country on the path of defence transformation, although critics raised questions in relation to various aspects of this multifaceted process. Despite hurdles, new policy documents were released by the government and the level of defence spending was stabilized; the Romanian armed forces proceeded vigorously with organizational and doctrinal reforms; and Romanian troops became an integral part of the US-led war against terrorist and insurgent groups. Issues of civil-military contention will be explored in greater detail in Chapter $\mathrm{V}$ of this thesis.

\footnotetext{
${ }^{374}$ Interview with Maj.-Gen. Teodor Frunzeti, by Capt. Marian Predoaica, "Armata - institutie de prestigiu a statului," Spirit militar modern, no. 1-2/2005.
} 


\section{Patterns in Post-9/11 Civil-Military Relations}

\section{V.1. Introduction}

The present chapter assesses the state of civil-military relations in Canada and Romania (taken separately) during the period under study, September 11, 2001-September 11, 2006. Each of its two main segments - focusing on Canada and Romania - will include an introduction to the area of civil-military relations in each respective country, followed by the analysis of five different topics relevant to the interaction between civilian and military leaders. They are the five intermediate variables explored in the previous chapter: (i) defence spending, (ii) government policies, (iii) defence transformation, (iv) relations with the United States and (v) military responses in the new security environment. Each introductory section itself is also divided into several subsections: (a) a general overview of civil-military relations in each country, (b) an analysis of the roles of the main organizations involved in the system of civil-military relations (Cabinet, Parliament, the armed forces, etc.), (c) a short assessment of the relative importance of parliamentary oversight in each of the two polities and (d) a succinct account of the relationship between civilian authorities and their military counterparts following the end of the Cold War. 
The two main segments of this chapter, looking at the state of civil-military relations in Canada and Romania during the 2001-2006 period, will be followed by a brief assessment of the findings. Specifically, this final section will formulate the answer to one of the key questions posed by this thesis: were civil-military relations in the two countries investigated here "good" - using Michael C. Desch's terminology and methodology - during this five-year timeframe? The answer to this question will indicate - in the particular security configuration revealed by Chapter III - "who prevail[ed] when civilian and military preferences diverge[d]," more specifically whether during the first half-decade of the post-9/11 era "the military play[ed] an important role in [the two countries'] political decision-making." By looking at the five issue areas that "pitted military preferences against those of civilians" in the two polities, the thesis supports the case for military preferences prevailing some of the time, i.e., civilian control of the military that, according to Desch, is "not firm." ${ }^{\text {375 }}$ The theoretical implications of these findings will be explored in the next, concluding chapter of this thesis.

\title{
V.2. Civil-military relations in Canada
}

\author{
V.2.a. Introduction
}

\section{V.2.a.i. General overview}

For the past few decades, Canadian civil-military relations have been characterized at times by dissonance between the country's political and military leaders. While

\footnotetext{
${ }^{375}$ Michael C. Desch, Civilian Control of the Military, 5.
} 
politicians have occasionally been accused of being disinterested in security and defence matters, the military has expressed - mostly indirectly - some concerns about levels of defence spending and the country's defence policies. While tensions have arisen on occasion between senior military leaders and officials, on the one hand, and Prime Ministers, Ministers of National Defence and senior public servants, on the other, Parliament has largely been absent from complex debates on security and defence issues. Gen. (ret'd) Gerard Thériault identified two main challenges in Canadian civil-military relations: "the challenge of political control, on the one hand, and the responsiveness, adaptability and cost-effectiveness of armed forces in conditions of political, strategic and economic change, on the other."${ }^{376 *}$

9/11 represents a breaking point in these patterns, in that the previous state of affairs became untenable: in a context in which there is a perceived need for complex, largescale, politically controversial military deployments abroad in the new war against terrorist and insurgent forces, all partners have seen their stakes rising. Nonetheless, post9/11 civil-military relations in Canada have been anything but harmonious. The military has demanded increased funding for, and a larger "say" on, its highly dangerous and sensitive operations overseas; successive minority governments have seen their ability to make defence a priority agenda item restricted; and Parliament has been unable to overcome its traditional inability to deal in a systematic manner with security and defence issues.

\footnotetext{
${ }^{376}$ Gen. (ret'd) Gerard Thériault, "Democratic Civil-Military Relations: A Canadian View," in The Military in Modern Democratic Society, ed. Jim Hanson and Susan McNish, Toronto: Canadian Institute of Strategic Studies, 1996, 4.
} 
In the words of Douglas L. Bland, "[p]olitical inattention, a significant degree of independence and discretion on the part of senior officers and officials, and disharmony followed by surprise are the chief characteristics of civil-military relations in Canada. The fault $[\ldots]$ comes from both camps. ${ }^{, 377}$ Following the events of September 11, 2001, and the ensuing war against terrorist and insurgent groups in far-away places, politicians have become more interested in security and defence matters, while senior military officials have seen the armed forces' needs recognized more forcefully and have understood the necessity of working more closely with their civilian counterparts. Philippe Lagassé and Joel Sokolsky argue that this civil-military rapprochement can be explained in part by the Canadian Forces' growing level of "recognized expertise in using force to guarantee national security," which gave them "moral weight and sway $[\ldots]$ to challenge the policy preferences of their civilian principals."378

Why these changes have not led to improved civil-military relations has to do with differences in positions taken by military and political leaders on a variety of topics. According to Janice Gross Stein and Eugene Lang, "[w]hat is important to military leaders is often irrelevant to civilians, and what is vital to civilians is frequently of no importance whatsoever to the military." ${ }^{379}$ The armed forces' occasional desire to bypass both Cabinet and Parliament when their key interests have been at stake, which in itself seems to undermine Canada's system of democratic civilian control over the military,

377 Douglas Bland, "Who decides what? Civil-military relations in Canada and the United States," Canadian-American Public Policy, issue 41 (February 2000), 10.

${ }^{378}$ Philippe Lagassé and Joel Sokolsky, "A Larger 'Footprint' in Ottawa: Canada's Evolving Civil-Military Relationship," paper presented at the International Studies Association's $49^{\text {th }}$ Annual Convention Bridging Multiple Divides, San Francisco, CA, March 26, 2008.

${ }^{379}$ Janice Gross Stein and Eugene Lang, The Unexpected War, 9. 
comes in reaction to what some analysts called "unwarranted political influence, incompetence and mismanagement" by "successive Liberal and Conservative governments. ${ }^{" 380}$ Yet other observers point to a tendency on the part of Canada's military leaders to make decisions and express views in their area of competence and beyond "as though they were free of 'the facts of national life'."381 To better understand the background against which these positions were articulated, the next section of this chapter's introduction will provide a short overview of the institutional setting relating to Canada's system of civil-military relations.

\section{V.2.a.ii. Roles and functions}

The Cabinet of Canada

Technically a Committee of the Queen's Privy Council for Canada - a reference to the country's past, when its members were advisors to the British Monarch - the Cabinet of Canada is in fact the Government's executive body, holding a tremendous amount of power. In a Westminster political system such as Canada's, the main executive institution of the state concentrates power disproportionately in its favour. As Cabinet members are generally chosen from the House of Commons and the Senate and the Government is formed based on the political configuration of the House of Commons, following elections, the Cabinet of Canada is in a politically sound position to make important decisions for the country.

\footnotetext{
${ }^{380}$ Fred R. Fowlow, "Have You Heard?," On Track, vol. 9, no. 3 (Autumn 2004), 12.

${ }^{381}$ Douglas Bland, "Who decides what?," 10.
} 
Headed by a Prime Minister (usually, the head of the party that wins the most seats in the House of Commons), the Cabinet comprises Ministers (also referred to as Ministers of the Crown), who administer government departments and agencies. Each Cabinet member is held accountable for the activity in his/her formal area of competence (which is referred to as individual ministerial responsibility), but the Cabinet is also accountable as a whole to Parliament (collective ministerial responsibility).

Ministers supervise the performance of the Public Service in relation to their government portfolios, yet the Cabinet is also responsible for initiating legislation, setting strategic directions for the country and conducting international affairs. Although the Governor General is, de jure, the Commander-in-Chief of the Canadian Forces, it is the Prime Minister who has de facto authority over the military. It is also the Prime Minister who appoints the Chief of the Defence Staff and who, "of course, exercise[s] control in other customary ways by, for instance, opening and closing the doors to the treasury, supporting favoured projects, and championing the armed forces in public."”82

The Privy Council Office

The Privy Council Office (PCO) is the Cabinet secretariat and "the Prime Ministers' source of public service advice across the entire spectrum of policy questions and operational issues facing the Government, including matters relating to the management

${ }^{382}$ Ibid. 
of the federation and constitutional development." ${ }^{\text {383 }}$ Answerable to the Prime Minister, the Privy Council Office also provides support to other key government officials. PCO is headed by the Clerk of the Privy Council, who is simultaneously Secretary to the Cabinet, Head of the Public Service and Deputy Minister to the Prime Minister.

It acts separately from the Prime Minister's Office (PMO): whereas the Privy Council Office is mostly an interface between the Government and the Public Service, the Prime Minister's Office is particularly responsible for managing the agenda of the head of the Cabinet. Former Clerk of the Privy Council Office R.G. Robertson drew, in the early 1970s, a classic distinction in the Canadian political and public administration system between PMO and PCO: “The Prime Minister's Office is partisan, politically oriented, yet operationally sensitive. The Privy Council Office is non-partisan, operationally oriented, yet politically sensitive., ${ }^{, 384}$

Although some of its specific responsibilities change with every new Prime Minister in office, PCO plays an important role in assisting the Prime Minister in relation to appointments, mandates and government organization; in supporting the Cabinet and Cabinet Committees in their operations; in helping define government policy directions; and in providing advice on constitutional matters. Post-9/11, PCO received increased responsibilities in the areas of security and foreign policy.

\footnotetext{
${ }^{383}$ Privy Council Office, The Role and Structure of the Privy Council Office, http://www.pcobcp.gc.ca/default.asp?Page $=$ Publications $\&$ Language $=E \& d o c=$ Role/role e.htm, February 1999 (accessed March 15, 2006).

${ }^{384}$ R.G. Robertson, "The Changing Role of the Privy Council Office," Canadian Public Administration, vol. XIV, no. 4 (1971), 506.
} 
The Canadian Forces

While the Cabinet of Canada is ultimately responsible for the direction of the country's security and defence policies, the Canadian Forces is the main institution in charge of carrying out operations, under the command of the Chief of the Defence Staff. CDS follows the political orders of the Prime Minister (or he faces the risk of being discharged), yet, as Douglas L. Bland notes, "government ministers [...] must depend on CDS and his subordinates if they are to achieve the government's defence and military objectives. $" 385$

The Chief of the Defence Staff holds not only a liaison position between the Canadian Forces and the Cabinet, being at once the main official implementing government policy in this area and the chief advocate of the armed forces' interests; CDS is also fully responsible for the selection and promotion of most senior military officers, and for the implementation of key organizational aspects of the CF. For top military positions, it is the Minister of National Defence who promotes officers to general or flag rank, but even in those cases on the recommendation of CDS. As Douglas L. Bland explains, this arrangement "places a bar between professional and political appointments in the armed forces. ${ }^{386}$

\footnotetext{
${ }^{385}$ Douglas L. Bland, "Finding National Defence Policy in 2004," Canadian Military Journal, vol. 4, no. 4 (Winter 2003-2004), 7.

${ }^{386}$ Douglas Bland, "Who decides what?," 11.
} 


\section{The Parliament of Canada}

The Parliament of Canada is the legislative branch of the state, comprising three institutions: the Queen (represented by the Governor General), an appointed upper chamber (the Senate) and an elected lower chamber (the House of Commons). The Governor General and the Senate have mostly ceremonial functions and Parliament itself has seen in recent decades part of its authority being transferred gradually to the executive. Nonetheless, Parliament provides the fundamental democratic mechanism through which Canadian citizens confirm their confidence in, or change, the Government of the day and legitimacy is given to the Cabinet to lead the country.

The two Parliament chambers scrutinize, debate and pass bills (which are then granted the Royal Assent by the Governor General, making them laws); examine government policies and decisions (such as spending on specific programs or in various areas); hold hearings and produce reports on topics of public interest; and interact with other state institutions, nongovernmental organizations and constituents in parliamentarians' ridings. Of particular significance, the Minister of National Defence is "accountable to Parliament for the use of executive and expenditure authorities authorized by legislation, government policies and regulations." ${ }^{387}$

${ }^{387}$ Ross Graham, "Civil Control of the Canadian Forces: National Direction and National Command," Canadian Military Journal, vol. 3, no. 1 (Spring 2002), 23. 
Yet Parliament is not always consulted by the Cabinet on topics of great significance for the country, such as the deployment of troops overseas or the conclusion of international agreements. This has partly to do with what is perceived to be a "knowledge gap" in Parliament on particular topics, such as security and defence-related matters, but also with the fragmented nature of the political debate in Parliament, often shaped along party lines. Parliamentarians can, however, hold the Government accountable, inter alia by asking oral questions, doing Committee work and holding formal hearings. The next section of this chapter introduction will present a more elaborate picture of the place of Parliament in the system of civil-military relations of Canada.

\section{V.2.a.iii. Parliamentary oversight}

Canada's Westminster political system ensures that power is concentrated in the Prime Minister's hands and his or her Cabinet. When analyzing civil-military relations in Canada, and in most other liberal democracies, the interaction of military and political leaders is generally defined as relations between senior military officers and senior Executive officials (in this case, chief among the latter being the Prime Minister). The significance of this political configuration for Parliament is overwhelming and translates into a much diminished role for this institution in the fields of security and defence.

A systematic study of Parliament's role in this governance area argues that the Parliament of Canada is hindered in exercising its functions "partly by habit, by weak parliamentary structures, by the overtly partisan nature of modern parliaments, and especially by the 
great distance between the Hill and the Ottawa bureaucracy." ${ }^{388}$ In part as a legacy of this political arrangement, but also as a contributing factor to this setting, most Senators and Members of Parliament (MPs) show little interest and are hardly expert in security and defence matters. When some parliamentarians are genuinely interested and reasonably proficient in this field, they usually have to toe their party's line - political positions on such important matters as international affairs and military operations are generally decided in caucus meetings, prior to parliamentary debate.

While party discipline generally ensures the passing of government legislation in the House of Commons (the Cabinet itself being formed based on the political configuration in Parliament's lower chamber), the Senate by and large has a similar rubber-stamping role. On the one hand, the governing party (i.e., the Prime Minister) can appoint new Senators, over time, from amongst its supporters; on the other hand, the Senate is typically reluctant to block important legislation, with a growing number of observers calling it an obsolete organization, a remnant of a distant past. The situation doesn't change very much when it comes to specialized committees on security and defence matters in the House of Commons and the Senate - they function largely based on the same party loyalty basis. The Senate Standing Committee on National Security and Defence has been fairly proactive and largely non-partisan in its activity in recent years, which was the case to a lesser extent with the House of Commons Standing Committee on National Defence.

\footnotetext{
${ }^{388}$ Douglas L. Bland, "Parliament's Duty to Defend Canada," Canadian Military Journal, vol. 1, no. 4 (Winter 2000-2001), 38.
} 
Overall, despite genuine interest for parliamentary oversight of security and defence matters on the part of individual parliamentarians and the institution as a whole, the postCold War era and particularly the post-9/11 period have not revealed much progress in this respect. "While Canada became engaged in one crisis after another," Douglas L. Bland notes, "there were no serious debates in Parliament to establish clear priorities and a consensus on what the national interest was in making policy choices." ${ }^{.389}$ Bland and a growing number of other analysts (this author included) suspect that, in addition to the partisan political conversation, the increasingly complex nature of government policies and military operations for the newly discovered campaign against terrorist and insurgent forces could make Parliament's work more, rather than less, challenging - "thus making it impossible to erase the 'democratic deficit' and make Parliament the centre of Canadian political life. ${ }^{390}$

\section{V.2.a.iv. Three political regimes}

With Parliament far from having decisive influence on national defence, Prime Ministers have a crucially important role in shaping the debate on security matters and civilian officials' interaction with their senior military counterparts. For the purposes of this study, focusing on the five years following the events of $9 / 11$, three top political leaders decisively influenced the way civil-military relations evolved in Canada: Prime Ministers Jean Chrétien (until December 2003), Paul Martin (December 2003-February 2006) and

389 Douglas L. Bland and Roy Rempel, "A Vigilant Parliament: Building Competence for Effective Parliamentary Oversight of National Defence and the Canadian Armed Forces," Policy Matters, vol. 5, no. 1 (February 2004), 4.

${ }^{390}$ Ibid. 
Stephen Harper (starting February 2006). The three political regimes had their own distinct (yet not radically different) characteristics in relation to their take on national defence and patterns of civil-military interaction.

Jean Chrétien became Prime Minister of Canada in November 1993 and was widely known for his reluctance to increase defence spending, despite a large number of analysts arguing that maintaining the status quo would lead to military irrelevance for Canada. While most observers lauded his efforts to reduce the national debt and, at the same time, maintain a sizable Canadian presence internationally (including militarily, as a peacekeeping force), he received criticisms from some quarters for a perceived lack of commitment to the Canadian Forces' well-being. Hugh Segal saw Chrétien as "largely disengaged from the larger geopolitical world, and unenthusiastic about any military role for Canada in that geopolitical world;",391 Martin Shadwick argued that, "most importantly, he failed to fundamentally reassess defence requirements in response to changing international circumstances;",392 and Jack Granatstein argued that Chrétien "did not understand Canada's interests, nor did his government understand the USA response to $9 / 11 .{ }^{, 393}$ Other experts, however, made a case for proper levels of defence spending, given the Government's foreign policy and defence objectives.

Not surprisingly, the Chrétien era was characterized by civil-military tensions, the main cause of which was an apparent commitment-capability gap. In spite of these tensions

\footnotetext{
${ }^{391}$ Hugh Segal, "A Grand Strategy for a Small Country," Canadian Military Journal, vol. 4, no. 3 (Autumn 2003), 3.

${ }^{392}$ Martin Shadwick, "The Chrétien Legacy," Canadian Military Journal, vol. 4, no. 4 (Winter 2003-2004), 69.

${ }^{393}$ Col. Howie Marsh, "CDA Annual General Meeting," On Track, vol. 9, no. 1 (March 2004), 13.
} 
and 'the military's complaints, [the Chrétien government's] system of strict civilian control imposed [...] painful budget cuts on the CF with relative ease" - according to Lagassé and Sokolsky, "[t]he civilians' control was near total." 394 The appointment by Jean Chrétien, in June 2001, of Gen. Ray Henault as Chief of the Defence Staff secured the Prime Minister another two years in office with no major civil-military incidents; as CDS, Gen. Henault preferred to keep a low profile and to try appeasing both military and political camps. As Lagassé and Soolsky explained, “[p]ublic criticism of government policies was unacceptable [...]. Loyalty to Cabinet was a prerequisite for the job"395 (the situation would change radically with the arrival of Gen. Rick Hillier as Chief of the Defence Staff). The Prime Minister's decision to deploy Canadian troops to Afghanistan and to reject the United States' request to join its intervention in Iraq won him - despite initial military opposition - positive reviews.

Gen. Henault continued to hold the position of Chief of the Defence Staff after Paul Martin became Prime Minister, as head of a minority government, in late 2003; in February 2005, Gen. Henault would assume the position of Chairman of the NATO Military Committee in Brussels and be replaced as CDS by Gen. Hillier. During his relatively short stay in office, Paul Martin initiated measures to increase defence spending, promote more forcefully military procurement programs and support the Canadian Forces in his public interventions. Paul Martin also allowed the military to more forcefully express views on defence issues and to influence the policy-making

\footnotetext{
${ }^{394}$ Philippe Lagassé and Joel Sokolsky, "A Larger 'Footprint' in Ottawa." ${ }^{395}$ Ibid.
} 
process; the Prime Minister thus rebalanced the relationship between the Government and the military establishment.

In support of this view, various analysts point to Prime Minister Martin's decision to appoint Gen. Rick Hillier (an outspoken military officer), from among several top choices, to the position of CDS. Former Assistant Deputy Minister (Policy) at DND Kenneth Calder argued that "Hillier's appointment gave more clout to the military" - as opposed to the Chrétien era, with Paul Martin as Prime Minister and Gen. Hillier as CDS "the balance shifted toward the military" (the situation would be "slightly corrected" under the Conservative government). ${ }^{396}$ Paul Martin also chose to extend Canada's operations in Afghanistan, but - based mostly on electoral considerations - he rejected the idea of joining the United States' National Missile Defense system, an idea strongly supported by the military (as well as most civilian officials at DND). Especially this latter episode raised concern among defence analysts and officials about the Prime Minister's willingness to shoulder the consequences of supporting the Canadian Forces in the face of some opposition from the Canadian public.

As columnist James Travers observed, "Martin's strength is connecting Canadians to bold concepts; his weakness is failing to match action to rhetoric." ${ }^{397}$ Doubts were raised once again in January 2006, when the Liberals posted on their website an electoral campaign ad that seemed to suggest Canadian cities would be subject to military

\footnotetext{
${ }^{396}$ Interview with Kenneth Calder (former Assistant Deputy Minister, Policy, Department of National Defence of Canada), by the author, Ottawa, ON, July 9, 2008.

397 James Travers cited in Fred R. Fowlow, "Have You Heard?," On Track, vol. 9, no. 3 (Autumn 2004), 12.
} 
occupation under a new Conservative government. Media organizations were flooded with messages from outraged military personnel and Gen. Rick Hillier said publicly he felt "like almost every other man and woman in uniform [...] insulted by that commercial ${ }^{398}$ - while endorsing the Conservative campaign platform in the area of national defence. Canadian media argued that "his strong, public response to the Liberal ad [...] reflects just how deeply offended the military establishment was. ${ }^{\text {"399 }}$ His response also reflected a new level of military assertiveness: Gen. Hillier "came in with more political support than any other CDS in the recent past" and "he took advantage of that support." ${ }^{400}$ Peggy Mason, a former U.N. ambassador who worked for Gen. Hillier said the General "professes non-involvement in politics, [but] has a clear political agenda and he's been very successful at advancing it." ${ }^{401}$ While Gen. Hillier's personality played a role in recalibrating the civil-military relationship, Lagassé and Sokolsky argue that "the CF's larger 'footprint' abroad," particularly in Afghanistan, allowed the military "to secure higher ground on Ottawa's political an bureaucratic battlefields. ${ }^{~} 402$

The Conservative victory in the 2006 federal elections would bring a radical change to Canada's political life: not only a new Prime Minister, but also a new political force that had been out of power for over a decade. Gen. Hillier's electoral endorsement of its campaign platform - which seemed to reflect a more pro-military political stance than the Liberals' - made news headlines and led many analysts to question the appropriateness of such an intervention. Relations between the Chief of the Defence Staff and Prime

\footnotetext{
398 ***, "Hillier rebukes Liberals," Metro Ottawa, February 1, 2006.

399 Ibid.

${ }^{400}$ Interview with Kenneth Calder, by the author.

${ }^{401}$ Cited in: Peter Pigott, Canada in Afghanistan: The War So Far, Toronto: Dundurn Press, 2007, 103.

${ }^{402}$ Philippe Lagassé and Joel Sokolsky, "A Larger 'Footprint' in Ottawa."
} 
Minister Stephen Harper were mostly convergent during the period covered by this study to the extent that both strongly supported Canada's operations in Afghanistan and were committed to improving the state of the Canadian Forces.

Higher public recognition of the armed forces' effort, higher levels of defence spending and a more efficient military procurement process were some of the most important elements on the two officials' agendas. Tensions arose, however, when the outspoken CDS repeatedly declared his dissatisfaction vis-à-vis defence budget levels and dabbled in the realm of policy making, by expressing views on Canada's foreign affairs and security issues. In April 2006, the Chief of the Defence Staff was reportedly asked "to submit advance copies of his public speeches for vetting by the Harper government, a move critics say shows mistrust of the country's blunt-spoken senior general. ${ }^{, 03}$ This move on the part of Mr. Harper's government was meant to reassert civilian control over the country's important defence file.

Tensions reportedly continued to exist below the surface after this incident, with military and civilian leaders clashing over the Prime Minister's decision to temporarily restrict media access to repatriation ceremonies for Canadian soldiers killed in Afghanistan. The decision, presented by government officials as a move to protect the privacy of soldiers' families, was widely thought to be driven by the Prime Minister's attempt to minimize the public's exposure to the ultimate image of war. Documents obtained by the Canadian Press under the Access to Information Act indicate that "[s]enior military officials opposed the Conservative government's controversial ban on media coverage" by raising

\footnotetext{
${ }^{403}$ Michael den Tandt, "Ottawa seeks closer watch on top general," The Globe and Mail, April 19, 2006.
} 
the issue of the safety of journalists covering the homecoming ceremonies from outside the airport gates, by clearing military equipment from the airport tarmac and, generally, by expressing their displeasure with the new policy. ${ }^{404}$

Relations between Gen. Hillier and Defence Minister Gordon O'Connor would worsen in late 2006 and 2007 (Mr. O'Connor would eventually be replaced by Peter MacKay). Many analysts noted not just differences in their views on military priorities, but also an inability to "get along personally" - the problem between them as L. Ian Macdonald put it, "is that a four-star [general - Rick Hillier] is working for a one-star [general - Gordon O'Connor]. ${ }^{, 405}$ Don Martin pointed to an "understandable jealously breaking out as the media-savvy Hillier attracts rock-star billing and his troops' adoration, while crusty O'Connor delivers the equipment and gets written up as a belligerent blowhard." ${ }^{406}$ In a revealing statement of his broad approach to leading the military, Gen. Hillier described, in early 2007 , the previous Liberal governments' record on defence as a "decade of darkness" and, referring to the relationship with his civilian masters, he said: "as the Chief of the Defence Staff, I care not who governs our country, as long as they support the Canadian Forces." ${ }^{407}$ It was not just Gen. Hillier's outspoken style that posed problems for the civil-military relationship, but also the fact that the CDS seemed to contradict his civilian principals in public. In 2007 the Harper government would begin to remind Gen. Hillier that final authority for policy making rests with the civilians, thus

\footnotetext{
${ }^{404}$ Alexander Panetta, "Internal documents hint at military's discontent with Tory repatriation policy," The Canadian Press, July 2, 2006.

${ }^{405}$ L. Ian Macdonald, "A problem of communication," The Gazette, August 1, 2007.

${ }^{406}$ Don Martin, "Showdown over military's direction rankles top general," The Gazette, February 16, 2007.

407 ***, "Top general's comments anger Liberals," Toronto Star, February 16, 2007.
} 
"reassert[ing] a more traditionally Canadian degree of civilian control over the CF," while "keep[ing] its confrontation with Hillier out of sight.",408

\section{V.2.b. Defence spending}

The typical patterns of interaction between the military and civilian authorities in Canada in recent decades involved, inter alia, uneasiness on the part of politicians with the idea of high defence budgets, mistrust on the part of military personnel vis-à-vis politicians' rhetorical commitment to the well-being of the armed forces and, generally, tensions over defence spending levels. The military perceived its institutional needs as being neglected among other government priorities (the argument went as far as to suggest that some political leaders deliberately tried to undermine the Canadian Forces), while the country's civilian leaders tended to believe that Canada's security needs were satisfactorily addressed with the given military capabilities and defence funding. ${ }^{409}$

These were largely irreconcilable differences, with both sides overstating at times their stance. While the situation was manageable and tensions did not degenerate into fullblown conflicts prior to the events of September 11, 2001, a new international threat environment - perceived as indeterminate, but potentially more dangerous - pushed the two sides toward confrontation. In trying to advance their demands for higher defence spending levels, both prior and after 9/11, the Canadian Forces "relied on a number of

${ }^{408}$ Philippe Lagassé and Joel Sokolsky, "A Larger 'Footprint' in Ottawa."

${ }^{409}$ Scot Robertson, "Years of Innocence and Drift: The Canadian Way of War in the Post-Cold War Era," in The Canadian Way of War: Serving the National Interest, ed. Col. Bernd Horn, Toronto: Dundurn Press, $2006,364$. 
retired officers, defense academics, journalists, and defense-sector lobbyists to air the military's concerns." ${ }^{410}$ By looking at the issue of defence spending, which pitted the military against civilians, this section will investigate whose preferences prevailed. An analysis of civil-military developments in the five-year period covered by this thesis suggests the balance leaning toward military preferences.

Colin Kenny, the chairman of the Senate's Standing Committee on National Security and Defence, noted that "Canadian prime ministers have failed to understand that the country doesn't have a large enough military for the missions politicians assign it" ${ }^{\text {"411 }}$ (the commitment-capability gap argument). A 2002 report by Mr. Kenny's committee showed how senior military leaders such as Vice Adm. Ron Buck, Chief of the Maritime Staff, Lt.-Gen. Mike Jeffrey, Chief of the Land Staff, and even Gen. Ray Henault, Chief of the Defence Staff, pointed publicly to the un-sustainability of Canadian Forces preparedness due to low defence spending levels. ${ }^{412}$ Many others agreed with this assessment: not only the Senate's defence committee, but also the House of Commons' Standing Committee on National Defence, as well as the federal Auditor General repeatedly emphasized that, as Auditor General Sheila Fraser put it, "the Canadian Forces do not have much capacity to tolerate further decline." ${ }^{, 43}$

The lack of resources provided to the Canadian Navy, for instance, could jeopardize this service's future, analysts argued. "The navy is invariably taken for granted except when

\footnotetext{
${ }^{410}$ Philippe Lagassé and Joel Sokolsky, "A Larger 'Footprint' in Ottawa."

${ }^{411}$ Richard Foot, "Tug of War," Ottowa Citizen, September 25, 2004.

${ }^{412}$ David Pugliese, "Canada's 'Analysis Paralysis," Ottawa Citizen, September 27, 2004.

${ }^{413}$ Michelle MacAffee, "Sheila Fraser on the Canadian Forces," CNEWS, December 4, 2001.
} 
things go wrong. It cannot be taken for granted much longer, because rust-out of the fleet will set in without decisive action in the near term," argued Peter Haydon of Dalhousie University. ${ }^{414}$ Defence analysts and navy leaders pointed out that the Canadian Navy needed to devise plans to replace part of the aging fleet as soon as possible if it wanted to maintain at least the country's existing naval capacity. Even so, they emphasized, "it takes at least 15 years to build and commission new ships. Canada's current destroyers [HMCS Algonquin, HMCS Athabaskan, HMCS Huron and HMCS Iroquois], already long in the tooth, aren't expected to last another decade and a half." ${ }^{\text {,415 }}$ A similar picture was generally painted by pundits and military officials in regards to the state of Canada's army and air force.

This bleak picture can be contrasted, however, with the view that the perceived problems are not as significant as alarmist observers would make us believe. Responding to critics of government actions, Terry Copp of Wilfrid Laurier University argued that the size of Canadian Forces and investment in the military were appropriate for a country like Canada: what the country needs is "a military very similar to the one it has now, but which is under less operational stress in terms of the number of operations it's called to do." ${ }^{.916}$ Joel Sokolsky of the Royal Military College of Canada argued that the fundamental weakness of the argument used by proponents of soaring defence spending resided with the fact that "it has always been difficult $[\ldots]$ to argue that a specific,

\footnotetext{
${ }^{414}$ Peter Haydon, "We can't afford to let our navy rust out," National Post, Nov. 29, 2004.

${ }^{415}$ Richard Foot, "On board of the navy's fragile flagship," Ottawa Citizen, November 20, 2004.

${ }^{416}$ Cited in: Richard Foot, "Tug of War."
} 
particularly higher, level of contribution translates directly into the enhanced achievement of specific, vital national interests." ${ }^{417}$

In other words, going beyond the fact that politicians tended to overlook the plight of the Canadian Forces, the high levels of defence spending requested by top military brass would have no solid justification except the advancement of the Department of National Defence and the Canadian Forces' institutional interests and influence amongst state organizations. The crux of the matter: "the CF has, despite its well-documented deficiencies, generally supported the pursuit of [Canadian] foreign policy objectives, to the extent that armed forces is relevant to their achievement." ${ }^{\text {418 }}$ The new international threat environment serves as the background against which heightened civil-military tensions over levels of defence spending emerged - an era in which the armed forces advanced more proactively its immediate institutional interests, occasionally at the expense of harmonious cohabitation with the Government.

Several particular instances and related developments reveal the extent to which the disagreements over defence funding intensified during the first five years of the post-9/11 era (even after Prime Ministers Martin and Harper announced increases in defence budgets) and the extent to which the military made inroads in advancing its institutional agenda. Canadian military leaders were well aware that it was inappropriate, given civilmilitary custom and tradition, to challenge the country's civilian authorities, including the government's position on defence spending. Yet the post-9/11 era reveals a growing

417 Joel J. Sokolsky, "Clausewitz, Canadian Style?," Canadian Military Journal, vol. 3, no. 3 (Autumn 2002), 7.

${ }^{418}$ Ibid. 
number of such occurrences (listed later in this section), involving senior military leaders, which arguably determined political authorities to change their stance on the topic. Assuming the two parties held conflicting views in relation to what was deemed proper level of funding for the armed forces (and for the most part the empirical evidence indicates they did), significant increases in defence funding suggest the balance leaning toward the military's position.

The military decided it was no longer in its, and for that matter the country's, interest to maintain its politically obedient position. Even the normally tactful Chief of the Defence Staff Gen. Ray Henault told the Senate committee on defence in 2002 that "the status quo is unsustainable," while Army commander Lt.-Gen. Mike Jeffrey and Navy chief Vice Adm. Ron Buck criticized the chronic lack of resources their services faced; ${ }^{419}$ Vice Adm. Ron Buck wrote in a report, "[o]ur ability to sustain a credible and relevant maritime force is at risk, the implications of shortfall in funding are significant. ${ }^{, 420}$ In retrospect, David Collenette, Minister of National Defence under Jean Chrétien, gives legitimacy to the military leaders' position: he argues that his former boss, Prime Minister Chrétien, cut defence spending too much. Citing as an example the Government' decision to delay buying four used British submarines in the mid-1990s, for electoral reasons, Mr. Collenette told a parliamentary committee that "Canadians really have to face up to the fact that you can't have your cake and eat it too. [...] You can't keep calling on the military unless you give them the resources." ${ }^{421}$

\footnotetext{
${ }^{419}$ David Pugliese, "Canada's 'Analysis Paralysis."

${ }^{420}$ Bruce Campion-Smith, "Aging navy at risk, Senate warned," Toronto Star, February 15, 2005.

${ }^{421}$ Mike Blanchfield, 'Chrétien cut Forces too deep: Collenette,' Ottawa Citizen, December 14, 2004.
} 
Gen. Henault and his colleagues' statements, along with similar positions expressed at other levels of the military hierarchy, represented only the beginning of a campaign by the Canadian Forces and the larger defence community to increase military funding in the new security environment. Navy chief Vice Adm. Bruce MacLean pointed to "decaying infrastructure, a depreciating asset base, increasing personnel issues, and a fleet that faces considerable sustainment issues;" Air Force chief Lt.-Gen. Ken Pennie stated, "the air force we have today is not sustainable tomorrow;" and Army chief Gen. Rick Hillier argued that "the cumulative costs of not funding programs are not only significant and growing, but oftentimes are hidden insofar as they contribute to skill fade, career stagnation, and asset deterioration beyond economical repair." ${ }^{\text {,422 }}$ The arrival of Gen. Hillier as Chief of the Defence Staff would only increase the pressure on the Government - his blunt talk and straightforward stance on a variety of issues, from defence spending to foreign policy priorities, would encourage others to follow suit and would coincide with tensions in relations between senior CF leaders and top government officials.

At the very ceremony for his appointment as Chief of the Defence Staff, in February 2005, Gen. Hillier told Prime Minister Paul Martin and Minister of National Defence Bill Graham that "[i]n this country, we could probably not give enough resources to the men and women to do all the things that we ask them to do. [...] But we can give them too little, and that is what we are now doing." ${ }^{223}$ Although Mr. Martin had personally appointed Gen. Hillier as CDS, being aware of his loquacious style but also his desire to

\footnotetext{
${ }^{422}$ Cited in: Stephen Thorne, "Rick Hillier," International Journal, vol. 60, issue 3 (Summer 2005), 829.

${ }^{423}$ James Gordon, "New military chief attacks underfunding," Ottawa Citizen, February 5, 2005.
} 
drive forward the CF transformation, most analysts argue that his early positions on the Government took the Prime Minister by surprise.

The incident was followed a few days later by other statements by top military brass, such as Lt.-Gen. Ken Pennie, the head of the Air Force, telling the Senate defence committee that the resources of his service were "somewhat depleted" after years of downsizing and "the air force faces a sustainability gap in its ability to generate operational capability." ${ }^{, 424}$ Chief of the Maritime Staff Vice Adm. Bruce MacLean told the same committee that the Navy faced very serious sustainability issues. Although not necessarily a result of these positions, the 2005 federal budget, released later that month, reflected military concerns over levels of defence funding; the Government pledged an additional $\$ 12.8$ billion for the Department of National Defence over the following five years. "We'll look back and see this was a turning point for the armed forces," Chief of the Defence Staff Gen. Hillier said in an April 2006 interview. ${ }^{425}$

However, this did not stop senior military officials from mounting their offensive for additional defence spending. Throughout his first months as Chief of the Defence Staff, Gen. Rick Hillier continued to be the strongest proponent of increased levels of funding for the Canadian Forces; along with the chiefs of the navy, the army and the air force, he painted a gloomy picture of Canada's armed forces: a military that faced imminent demise. These positions occurred in a context in which, during the previous decade, as Lagassé and Sokolsky point out, "[h]igh-ranking military officers $[\ldots]$ were stunned by

\footnotetext{
${ }^{424}$ Stephen Thorne, "Air force is pushed past limit, Ottawa told," The Globe and Mail, February 8, 2005.

${ }^{425}$ Interview with Gen. Rick Hillier, by John Geddes, "'If we don't bring stability to places like Afghanistan, they will bring instability to Canada," Maclean's, April 11, 2005.
} 
the magnitude of the budget reduction. [...] Some senior officers resigned and publically chastised the Chrétien government.",426

While Minister of National Defence Bill Graham attempted to shed light on positive developments in relation to Canada's military establishment, his voice tended to be lost under the loud roar of angry servicemen and women. Conservative Defence Critic Gordon O'Connor - later Minister of National Defence - blasted the Liberal government in 2005 for what his party perceived to be an insufficiently high level of defence spending, which only provided the military with fresh ammunition (in 2006, Minister O'Connor would experience himself criticism over his government's stance on security and defence issues). Encouraged by a wave of media attention to military matters, Gen. Hillier suggested in late 2005 that he would rely on the Canadian public, rather than the country's political authorities, to save the armed forces - a radical departure from the traditionally acquiescent role of a Chief of the Defence Staff. ${ }^{427}$

In early'2006, before the release of the Canadian federal budget, Gen. Hillier continued forcefully his campaign for a higher share of the federal budget. "It takes money," he said in an early 2006 speech to the Conference of Defence Associations, asking for "more people, new equipment and better conditions for the troops [...]. We remain short about three quarters of a billion dollars just to sustain the present Canadian Forces. ${ }^{, 428}$

\footnotetext{
${ }^{426}$ Philippe Lagassé and Joel Sokolsky, "A Larger 'Footprint' in Ottawa."

427 ***, "Canadian Forces chief says the public, not politicians, will save the military," The Brandon Sun, November 25, 2005.

${ }^{428}$ John Ward, "Military can't afford basic bullets and beans," The Canadian Press, February 24, 2006.
} 
Following a $\$ 1.1$ billion top-up in the country's defence budget, ${ }^{429}$ the Conservative government would announce a large procurement program in mid-2006, designed to reequip all military services within a few years, with an emphasis on the army and the air force.

The fact, however, that in late 2006 (the end of the timeframe employed by this thesis) top military brass carried on with their efforts to seek a bigger slice of the federal budget pie, despite significant achievements, projects the image of a civilian leadership on the defensive. On this particular item (defence spending) there is strong evidence that the military was successful, during the 2001-2006 period, in advancing its institutional agenda. Undoubtedly, in releasing beefed-up defence budgets, Canada's post-9/11 governments must have taken into consideration the requirements of a novel international threat environment (having a direct, independent impact on government decisions). Yet the analysis of civil-military patterns during this period suggests that increases in government spending and new budget supplements were closely correlated with campaigns on the part of the military (and sympathetic NGOs run by retired officers), demanding a larger share of the country's treasure.

The new security environment acted as a facilitating backdrop, giving the armed forces' demands more weight. The military's post-9/11 stance vis-à-vis government decisions on military expenditure was suggestively expressed by a line in an article signed by Brig.Gen. (ret'd) Jim Cox: "With money only promised in future years, one might be tempted

\footnotetext{
${ }^{429}$ Department of Finance, Budget 2006: Focusing on Priorities, http://www.fin.gc.ca/budtoce/2006/budliste.htm, May 2, 2006 (accessed May 2, 2006).
} 
to bash a counter and ask, "Where's the beef?"' The where's-the-beef slogan proved to be more than a catchy phrase during the first five years of this new era; it was a new approach to handling the military's relations with its civilian masters - a strategy that changed the nature of the civil-military relationship and arguably contributed to increased levels of defence spending.

\section{V.2.c. Government policies}

Difficulties in managing the interaction between civilians and the military in Canada in the process of shaping defence policy are due to a series of systemic conditions affecting civil-military relations in this country. Maybe the most important factor in this respect is a customary lack of interest on the part of recent (particularly pre-9/11) governments on military issues: Canadian governments would engage in this process only to the extent that existing policy documents had become obviously obsolete. Another important factor is the tendency on the part of the Canadian military establishment to try to influence government decisions on military issues and, more broadly, to be an active participant in setting national security and defence priorities.

This second factor emerged partly by default and partly by design - the military felt compelled to "do policy" when faced with unwilling political authorities, while top military brass also sensed an opportunity to advance institutional goals in suitable threat environments. Their involvement in the policy arena was facilitated by what former Prime Minister Paul Martin saw as questionable expertise on the civilian side: "Over 
twenty-five years, due to the combination of Michael Pitfield's centralization initiatives and my budgets, we have totally destroyed the policy-making capacity of the public service." ${ }^{\text {430 }}$ This leads us to the third significant factor, the security environment: the post-9/11 era provided the context in which top military officers decided to push their organizational agenda, at the same time that the country's political leaders were forced to live up to their obligations and become more active in the policy arena. With no magic bullet in sight (offering optimal responses to a largely unspecified security environment) and, on a regular basis, lack of convergence between the two parties, debates on policy responses to the new threats have occasionally led to strain in post-9/11 Canadian civilmilitary relations.

Occasionally, members of Canada's defence community expressed forcefully and publicly their views on the country's defence policy and the management of the Canadian Forces. While "the army definitely needs to be bigger" according to Capt. Tyrone Green, ${ }^{431}$ Col. Pat Stogran saw the Government and the most senior CF leaders as "a bunch of mandarins that shove this peacekeeping down the throats of Canadians and say we're not a militaristic society." seen by Col. Stogran as "an absolutely unjust war. The reason didn't exist," but he approached the 1991 Persian Gulf War as "a just cause to be going into" and had felt "let down by our senior leadership," who "weren't prepared to get in and fight;" as a large

\footnotetext{
${ }^{430}$ Janice Gross Stein and Eugene Lang, 153.

${ }^{431}$ Richard Foot, "Tug of War."

${ }^{432}$ Mike Blanchfield, "We like a good punch-up,"” Ottawa Citizen, September 26, 2004.
} 
number of other military leaders, Col. Stogran believed Canada had to readjust its policies vis-à-vis its armed forces. ${ }^{433}$

At the same time that Col. Stogran seemed more than happy to lead his troops in Afghanistan, Lt.-Gen. (ret'd) Mike Jeffrey, Chief of the Land Staff thought Canada's military involvement in this Central Asian country was not "worth the risk, the cost, the potential downside cost" - Lt.-Gen. Jeffrey saw Canada's plan to send troops as part of NATO-led ISAF as a "high-risk operation" that he openly questioned. ${ }^{434}$ In 2006 , Lt.Col. John Conrad, commander of Canada's National Support Element in Kandahar argued that, on the contrary, "Canadians care about having a voice in the world, and that voice goes silent without boots on the ground. [...] You want a voice at the G-8, you gotta pay. I think Canada is ready for that." ${ }^{, 435}$ That same year, Gen. Rick Hillier added further policy arguments to the rationality behind Canada's presence in Afghanistan: "[w]hat we're looking for is the chance to have sufficient profile [...] sufficient credibility that gives the opportunity to get leadership appointments and shape regions and populations in accordance with our interests and in accordance with our values. ${ }^{\text {\$36 }}$

These exarnples are emblematic of situation in which military personnel have occasionally attempted to shape the direction of the country's stance on security and defence matters - or at least to express views in this area - despite that fact that, formally, "neither [the Chief of the Defence Staff] nor any other officer is responsible or

\footnotetext{
${ }^{433}$ Ibid.

${ }^{434}$ Interview with Lt.-Gen. (ret'd) Mike Jeffery, National Network News, vol. XI, no. 2 (Fall 2004).

${ }^{435}$ Cited in: J. L. Granatstein, Whose War Is It? 48

${ }^{436}$ Sharon Hobson, "Interview: General Rick Hillier, Canadian Forces Chief of the Defence Staff," Jane's Defence Weekly, August 9, 2006.
} 
accountable for the national defence or defence policy, ${ }^{, 437}$ As Ross Graham pointed out in a Huntingtonian vein, the difficulty of establishing defence policy arises from the position of political leaders being "dependent on the advice of [military] experts who may be in a conflict of interest position when they offer such advice." ${ }^{438}$ The military's proactive role in this area was most evident in the post-9/11 context, with the three factors mentioned above converging toward patterns of tense civil-military relations. As Douglas Bland explains, "[c]hiefs of the defence staff have exercised their rightful and implicit authority in a very nuanced and responsible way [...]. Nevertheless, policy disagreements, especially during defence emergencies, have from time to time exposed a fault-line in Canadian civil-military relations. ${ }^{.439}$

In the period immediately following $9 / 11$, the relations between Chief of the Defence Staff Gen. Ray Henault and the governments of the day (under Prime Ministers Jean Chrétien and Paul Martin) were relatively tranquil. Some military leaders felt, however, that the Canadian government's decision not to participate, alongside the United States, in the US-led intervention in Iraq was a major mistake, affecting negatively both the country's position on the international stage and the strategic interests of the Canadian Forces. ${ }^{440}$ Minister of National Defence John McCallum (serving under Prime Minister Chrétien) acknowledged that civil-military tension was caused, in 2003, by top Canadian Forces officers' clearly defined opposition vis-à-vis the Government's stance on the wars

\footnotetext{
${ }^{437}$ Douglas L. Bland, "Parliament's Duty to Defend Canada," 35.

${ }^{438}$ Ross Graham, "Civil Control of the Canadian Forces," 27.

${ }^{439}$ Douglas Bland, "Hillier and the new generation of generals: The CDS, the policy and the troops," Policy Options, March 2008, 56.

440 ***, "Chrétien government rejected military's advice on Afghan deployment: ex-army chief," $C B C$ News, October 18, 2006.
} 
in Iraq and Afghanistan (a policy area by definition). "They wanted to go into Iraq," McCallum remembers - "[t]he military leadership of the day wasn't terribly enthusiastic about Afghanistan." ${ }^{.441}$ The Government made it clear that Canada would not join the United States in its campaign in Iraq (except for a few liaison officers and, later on, limited personnel in charge of training Iraqi troops). Maj.-Gen. Cameron Ross, Director General of International Security Policy at DND's National Defence Headquarters, quit in June 2003, reportedly over the further deployment of Canadian troops to Afghanistan rather than Iraq. ${ }^{442}$

Partly recognizing the military's opposition to government defence plans and partly due to limited civilian policy capacity in this area, Prime Minister Martin and Minister of National Defence Bill Graham assigned Chief of the Defence Staff Gen. Rick Hillier as the person de facto in charge of the Government' defence policy. "The Prime Minister appointed Gen. Hillier," Minister Graham pointed out, "precisely because we wanted a strong voice to tell us how we can have the right strategic vision for this country and how we can acquire the assets." ${ }^{443}$ It was Gen. Hillier who saved the Defence Policy Statement, after initial drafts were reportedly "tossed out" by the Government, ${ }^{444}$ and who forcefully projected, and later started to implement, his own vision for the Canadian Forces and the country's position on security and defence matters. Former Prime Minister Paul Martin recalled that episode in a 2006 interview: "[Minister of National Defence] Bill [Graham] asked me for a new CDS to help him get the defence policy done. [Gen.

\footnotetext{
${ }^{441}$ John Geddes, "Bullets fly. Ottawa ducks," Maclean's, August 28, 2006, 26.

442 Ibid.

${ }^{443}$ Mike Blanchfield and Aileen McCabe, "Military leaders confident budget will offer \$1B extra," Ottawa Citizen, February 15, 2005.

${ }^{444}$ Stephen Thorne, "Defence minister rips military paper," The Canadian Press, February 11, 2005.
} 
Rick] Hillier then came to 24 Sussex and he put his perspective to me. I immediately agreed with it." ${ }^{\prime 45}$

Gen. Hillier reportedly discarded altogether, as unacceptable, the philosophy behind existing DPS drafts, by "rejecting the [three-service] balanced approach in favour of a single service dominant (Army-centric) approach"446 and by promoting Army-based expeditionary forces to be deployed on short notice anywhere around the globe. James Fergusson noted in a 2006 commentary in relation to the DPS episode, that "accepting the CDS' defence policy implies that the military makes policy, rather than advises and implements" - Gen. Hillier's intervention "represents in this context the dominance of the "uniformed" [side within Canada's defence establishment], whereas putting it aside would signal the re-assertion not only of political control, but also civilian input into the process. ${ }^{\text {447 }}$ Former Assistant Deputy Minister (Policy) at DND Kenneth Calder pointed out that, in the process of writing the Defence Policy Statement, "the CDS and close military associates had more than the usual amount of influence on policy." Gen. Hillier who, in 2004, had initiated and successfully pushed through the idea of mixed civilian-military teams on the ground in Afghanistan (e.g., Provincial Reconstruction Teams), in his former position as commander of the International Security Assistance Force in Kabul. ${ }^{449}$

\footnotetext{
${ }^{445}$ Janice Gross Stein and Eugene Lang, 150.

446 James Fergusson, "Wanted? A Canadian Defence Policy," Canadian Defence and Foreign Affairs Institute Newsletter, Summer 2006, 2.

447 Ibid.

${ }^{448}$ Interview with Kenneth Calder, by the author.

${ }^{449}$ Robert J. Jackson, "Bureaucrats with guns: Canada's secret weapon," Ottawa Citizen, July 19, 2007.
} 
In 2006, it was still Gen. Hillier who set in an internal document the conditions for a "successful and completed" mission in Afghanistan - chief among them, when effective, new Afghan security forces "are established" and "fully controlled" by the Afghan government and when "terrorist groups are denied sanctuary within Afghanistan. ${ }^{.450}$ The terrorist attacks against the London transit system, in the summer of 2005, offered Gen. Hillier yet another occasion to venture into the policy domain, by projecting an image of Canada under attack by international terrorist elements - in opposition to the Government's attempt to assure the Canadian population of no immediate danger. By making defence policy his first priority, Gen. Hillier raised concerns among analysts and government officials - as Janice Gross Stein of the University of Toronto and Eugene Lang, chief of staff to the Minister of National Defence (2002-2006), noted, "[o]nce [Gen. Hillier] took over, defence policy became almost the exclusive domain of the military leadership. [...] Defence policy was historically, and quite appropriately, the domain of civilian officials, and it was unprecedented for a chief of the defence staff to be given this responsibility. ${ }^{451}$ In the end, all decisions were formally approved and publicly announced by the Government; to the extent that the military (or the Chief of the Defence Staff) drove the policy process in 2005-2006, this was done behind the scenes.

Gen. Hillier's and other top military leaders' most significant intervention in the policy arena occurred throughout the 2005-2006 period vis-à-vis Canada's mission in Afghanistan. Only a few months after taking over as Chief of the Defence Staff, Gen. Hillier found it necessary to publicly delineate the armed forces' mission in Afghanistan

\footnotetext{
450 ***, "Document outlines Canada's military plans in Afghanistan," CBC News, January 28, 2007. 451 Janice Gross Stein and Eugene Lang, 151 and 163.
} 
and, consequently, the essence of Canada's intervention in this Asian country - the military constituting the bulk of Canadian personnel there: “[w]e are going to Afghanistan to actually take down the folks that are trying to blow up men and women. [...] We are the Canadian Forces and our job is to be able to kill people." ${ }^{, 452}$ Gen. Hillier also described Canada's enemies in Afghanistan as "detestable murderers and scumbags," argued that al-Qaeda leader Osama bin Laden had long ago made Canada a target for terrorist attacks and likened the Taliban and al-Qaeda fighters to Canadian convicted murderers Clifford Olson, Paul Bernardo and Karla Homolka.

Also during the summer of 2005, Maj.-Gen. Andrew Leslie, Director General, Strategic Planning, National Defence, and former Deputy Commander of the International Security Assistance Force in Kabul, told an academic conference that "Afghanistan is a 20-year venture," but "there are things worth fighting for. There are things worth dying for. There are things worth killing for." ${ }^{453}$ Along with other military officials, Gen. Hillier advocated a 3-D approach to Canada's foreign interventions (defence, diplomacy and development), which would become the foundation of Canada's post-9/11 overseas security missions, particularly in Afghanistan - at least until the Conservatives' rise to power.

The military intervention in Afghanistan (particularly the 2005 Kandahar deployment) was dubbed by some media outlets "Hillier's War," a title that seems to underscore not

\footnotetext{
${ }^{452}$ Daniel Leblanc, "General's talk of terrorist 'scumbag' praised," The Globe and Mail, July 16, 2005.

${ }^{453}$ Maj.-Gen. Andrew Leslie, "Thoughts on the Future of the Canadian Forces," paper presented at the 74th Annual Couchiching Summer Conference Handcuffs and Hand Grenades: The Use of Force Within and Between Nations, Willowdale, ON, August 7, 2005.
} 
only the armed forces' desire to drive the post-9/11 war effort, but also the Government's initial inability and unwillingness to articulate this mission. Gen. Hillier "has no problem defending the mission or speaking on behalf of the men and women in uniform, but until recently the government had not stepped up to the plate," a DND source told the Canadian Press in late $2006 .{ }^{454}$ Shortly before the end of his mandate as CDS, in 2008, Gen. Hillier told CBC, "I articulated what we felt we could do as Canadian Forces [in Afghanistan]. I was very clear in my articulation and if my articulation of the logic of going into Afghanistan helped sway the Government in that direction, as they did, then 'good,' I was doing my job., 455

At a September 2006 meeting with senior federal officials, Gen. Hillier reportedly said that critics of the war had been offered an "open field" to "degrade public support for the mission. ${ }^{456}$ This tends to explain Gen. Hillier's forceful public campaign promoting the Afghan intervention, in which he was joined by other senior military leaders, such as Brig.-Gen. David Fraser, commander of Regional Command (RC) South in Kandahar (February-November 2006). Observers such as Liberal defence critic Ujjal Dosanjh stated that "it's not the job of the military to promote the mission - that's up to the government;", ${ }^{457}$ others argued, along similar lines, that "it is not Gen. Hillier's job to explain why our troops are in Afghanistan or to attempt to rally support for them being

\footnotetext{
${ }^{454}$ Murray Brewster, "Military worried about Tory failure to defend Afghan mission," The Canadian Press, October 1, 2006.

${ }^{455}$ Interview with Gen. Rick Hillier, by Wendy Mesley, www.cbc.ca (The National), April 15, 2008 (accessed April 17, 2008).

${ }^{456} \mathrm{Ibid}$.

${ }^{457}$ ***, "Canadians ill-informed about Afghan mission: Fraser," The Canadian Press, December 5, 2006.
} 
there. That is the job of the elected representatives of the Canadian people who decided to put our troops in that country.",458

Yet, throughout this period, Gen. Hillier and his top military advisors continued their public relations campaign in favour of the Afghan mission and of Canada's expeditionary, 3-D-based overseas interventions. Hinting that the Government is reluctant to explain the mission, Gen. Hillier was willing to assume that role: "one of those [soldiers] comes home in a body bag, and [if] I can't articulate, and you can't articulate, and we can't articulate as Canadians why that sacrifice was necessary, then we have failed them;" he added that as CDS he has a duty to the soldiers he commands: "when I send young men and women out of the country I just like to make sure they know why they are going and what they are going to achieve and why we are asking them to do that. ${ }^{.459}$ Gen. Hillier and the Harper government would also be "at odds over several issues," most of the tension stemming from differences between the 2005 Defence Policy Statement and the Conservative's Canada First defence strategy; Lagassé and Sokolsky identified three main areas of disagreement: the proposed acquisition of transport platforms (to be explored later in this chapter), Canada's policy on the Arctic and homeland defence approaches. ${ }^{460}$

All these developments over the period covered by this study - taken in themselves or compared with previous periods - provide evidence for a tendency of the military to

\footnotetext{
${ }^{458}$ Jack Glenn, "Harper right on Hillier," The Globe and Mail, April 22, 2006.

${ }^{459}$ Gen. Rick Hillier, "Setting Our Course," speech presented to the Canadian Institute for Strategic Studies Conference, Toronto, July 22, 2005.

${ }^{460}$ Philippe Lagassé and Joel Sokolsky, "A Larger 'Footprint' in Ottawa."
} 
compete with civilian authorities over, and even drive and announce, the country's policy agenda. Repeatedly, military leaders have lamented the Government's poor policy capacity, especially related to integrating the Afghan mission within the country's larger policy framework. As Col. D. Craig Hilton noted in 2007, the question the country faced after years of military involvement in Afghanistan was: "how do we connect past efforts with emerging policy and future objectives? In military parlance, making such a connection requires the unenviable 'reverse estimate' process, i.e., figuring out how we got here from there, and then rearranging the threads so as to weave a coherent position from which to proceed." ${ }^{461}$

While it might be argued that several factors have driven Canadian civil-military relations in this direction in the post-9/11 context, this thesis proposes that the overall threat environment was the facilitating background and the most important independent variable leading to the above-mentioned outcome. It influenced decisively the interaction between military and civilian elites, providing the latter with practical and conceptual security challenges they had not fathomed before and the former with an additional impetus to advance their institutional agenda. Assessing the patterns of civil-military interaction in relation to this area during the 2001-2006 period and the ensuing results, this study concludes that top military brass have managed to decisively influence the country's policy-making processes and thus transform the nature of the interaction between the armed forces and their civilian principals.

\footnotetext{
${ }^{461}$ Col. D. Craig Hilton, "Shaping Commitment: Resolving Canada's Strategy Gap in Afghanistan and Beyond," Strategic Studies Institute, the U.S. Army War College, http://www.StrategicStudiesInstitute.army.mil, July 2007 (accessed July 29, 2007).
} 


\section{V.2.d. Defence transformation}

The need for defence transformation in Canada became apparent from the early moments of the post-Cold War era, when the danger of a military confrontation with the Soviet Union was replaced by an amorphous international security environment. Revamping military doctrines, renewing equipment and reorganizing the defence establishment along new lines was, furthermore, widely perceived as a clear necessity after the events of September 11, 2001. While both military and civilian leaders have agreed over the general idea of transforming the armed forces to address more effectively novel, post9/11 security challenges, their positions have - at times - diverged over the practical ways of implementing this plan.

At strategic, operational and tactical levels, as well as in the area of defence procurement, the 2001-2006 period saw clashes, attempts by one party to impose its views over the other or simply decisions made unilaterally - by default - by one partner, usually the military, while the other lacked interest in the matters discussed. From defining the broad principles of defence transformation to changing the way operations are envisioned and conducted to acquiring new military capabilities, military and civilian leaders engaged in a complex process whose patterns will be investigated below.

As discussed in Chapter IV of this thesis, there was hardly agreement over the precise details of novel strategies, new equipment and institutional innovations. Despite this state 
of affairs, the post-9/11 military transformation was conducted forcefully, especially in the latter part of the 2001-2006 period, which raises the question of the driving actors behind this process and the ways to settle disagreements - particularly those opposing civilians to military leaders. This chapter proposes that defence transformation was decisively influenced at the strategic level by senior military staff (a departure from the traditional model of civil-military relations); at the operational and tactical level by both civilian and military leaders, with some disagreements over deployment of troops to, and roles in, particular theatres of operations; and in terms of defence procurement primarily by the armed forces, with civilians ultimately unable to fully impose their position on their military counterparts.

The following paragraphs will investigate each of these areas of civil-military interaction and provide evidence for these preliminary propositions. As in previous sections, the analysis of these empirical developments will lead to tentative conclusions on post-9/11 patterns of civilian control over the military in Canada. As a most important observation, at a strategic level the transformation of Canada's post-9/11 defence establishment was driven overwhelmingly by the armed forces: senior military leaders such as Chiefs of the Defence Staff Gen. Ray Henault and - especially - Gen. Rick Hillier resolutely shaped the direction of this process. While it is normal, according to the traditional model of civil-military relations, for the military to have a sizable "say" in the security and defence realm, what is notable from the post-9/11 picture in Canada is the weak presence of the political authority in this discussion. 
As presented in Chapter IV of this thesis, it was the military, most importantly the office of the Chief of the Defence Staff, that articulated the need for military transformation in an altered international threat environment and initiated concrete steps toward revamping the military institution. Gen. Henault's and Gen. Hillier's annual reports and occasional speeches defined the essence of defence transformation; complacency, different policy priorities or the inability to define the civilian side's position in this process left the Government in a role of rubberstamping military decisions. From linking the reform in this area with a new global security context to providing a radically new perspective on the institutional configuration of the Canadian Forces and their command structure to offering a roadmap for implementing the new vision at operational and tactical levels, it was predominantly military rather than civilian leaders having a decisive influence on these matters.

Brig.-Gen. Daniel Gosselin and Dr. Craig Stone noted that "[i]nitiatives of this magnitude create anxiety, foster rumours and generate suspicion, as options for change are being developed and important decisions are often made at a speedy pace, without the usual full consultation expected by some of the actors. ${ }^{, 462}$ As a relevant observation, the least significant opposition to the military-driven process of post-9/11 transformation came from the forces' direct political masters, the Government. Political authorities' main contribution in shaping the transformation of Canada's military establishment was indirect: decisions made by civilian and military leaders on deployment of troops

\footnotetext{
${ }^{462}$ Brig.-Gen. Daniel Gosselin and Dr. Craig Stone, "From Minister Hellyer to General Hillier," Canadian
} Military Journal, vol. 6, no. 4 (Winter 2005-2006), 10. 
overseas had the effect of reconfiguring the Canadian Forces toward an expeditionary, combat-focused, mobile and interoperable military establishment.

The Government's position on external interventions - primarily, the Afghanistan mission - largely coincided with the position of senior military brass; both sides favoured a pro-active policy in the international arena and forceful rules of engagement at theatre level. While the intervention in Afghanistan was a priority for the Canadian Government as a means to address new international security threats and to improve relations with the United States, the military also perceived it as an opportunity to advance its institutional agenda of increased defence spending and better positioning in the context of conflicting political priorities. The end result - for which neither civilian nor military leaders can claim full responsibility or merit - was a more agile, more easily deployable and better equipped military.

Serious disagreements occurred, however, over the issue of defence procurement, particularly relating to strategic lift. While the small-scale procurement programs announced during the tenure of Gen. Ray Henault as Chief of the Defence Staff did not cause any notable civil-military tensions, the situation would change significantly during his successor's term as CDS. As soon as Gen. Rick Hillier was installed by Prime Minister Paul Martin as head of the Canadian Forces, he repeatedly and forcefully underscored his resolve to pressure the Government into launching a comprehensive procurement program for Canada's military. His focus was, among others, on purchasing heavy-lift helicopters and short-haul transport aircraft for intra-theatre manoeuvres, while 
long-range flights could be handled by rented aircraft or other bilateral and multinational arrangements.

Gen. Hillier also insisted on the idea of federal funds being allocated toward purchasing a big amphibious expeditionary warship, able to carry up to 1,500 troops, as well as heavy army and air force equipment to various theatres of operation around the world. Lack of agreement on this subject between the Chief of the Defence Staff and Defence Minister Bill Graham (the warship would have come with a price tag in the range of \$1B), coupled with the prospect of new federal elections in which the governing Liberals were perceived as half-heartedly committed to the Canadian Forces' well-being, seemed to have convinced the Government of the necessity of investing more in the armed forces.

In a reversal of the Government's original position, Defence Minister Bill Graham announced in November 2005 a \$5-billion plan to replace the country's obsolete fleet of short-haul Hercules C-130 aircraft. Gen. Hillier praised the plan as "an essential tool that could save the lives of Canadian military personnel and allow the country to remain relevant on the international stage. ${ }^{, 463}$ The defeat of the Liberal government in the federal elections of early 2006 saw the multi-billion plan abandoned, reset the terms of the discussion and renewed civil-military tensions. The new Conservative government's main priority in the area of defence procurement was buying several long-range military transport planes, while downplaying the importance of short-haul aircraft for the Canadian Forces.

\footnotetext{
${ }^{463}$ Mike Blanchfield, "Liberals defend \$5B purchase of 16 planes," National Post, November 23, 2005.
} 
In line with Prime Minister Stephen Harper's position, Defence Minister Gordon O'Connor favoured a renewed emphasis on the North and the ability to ship troops and equipment overseas on short notice and over long distances. As Lagassé and Sokolsky pointed out, "[1]ed b y the CDS, senior officers attempted to delay the government's purchase of strategic lift aircraft in favor of tactical airlifters," but also to "block the creation of urban consequence management units, and compel Cabinet to reevaluate its plans for a larger CF presence in the arctic." ${ }^{, 464}$ Gen. Hillier's strong opposition, publicly and behind the scenes, sparked rumours of his forced departure as CDS and prompted Defence Minister O'Connor to underline in May 2006 that the country's political leaders, not the military, were in charge of the procurement file: "We are the government and we set the policy. The military and the public servants follow our policies." ${ }^{, 465}$

Just a month later, facing harsh opposition from defence associations and members of the Canadian Forces, active and retired, Defence Minister O'Connor - just like his predecessor - decided to try to reach a compromise with his military colleagues. In the avalanche of comments and opinion pieces relating to his position on this file, Minister O'Connor had largely been presented as "the voice of the past, a man trained in the Cold War who never got over it," while Gen. Hillier had acquired the image of a "more modern, a rapid-deployment guy who no longer worries about the Berlin Wall and the Communists. ${ }^{.466}$ Accurate or not, these images may have also contributed to the change

\footnotetext{
${ }^{464}$ Philippe Lagassé and Joel Sokolsky, "A Larger 'Footprint' in Ottawa."

${ }^{465}$ Michael den Tandt, "O'Connor denies rift with Hillier delaying military purchases," The Globe and Mail, May 4, 2006.

${ }^{466}$ John Gray, "What do we want the Canadian military to do?," CBC News, May 12, 2006.
} 
of heart on the part of the Defence Minister and to a government decision to spend \$8.3billion on 17 short-haul airplanes and four long-range aircraft.

"It is in the interest of Canada," Minister O'Connor would later say, "that the Canadian Forces possess both a strategic- and tactical-airlift capability. ${ }^{.967}$ The Chief of the Defence Staff was quick to present this compromise as an obvious choice for Canada, whose Government finally understood the necessity of such purchases. McGill University historian Desmond Morton noted, in a 2006 commentary, the extent to which Gen. Hillier was able to push his institutional agenda in debates with his civilian masters: "His predecessors were noted for their caution, their careerism and their absolute refusal to stick their necks out on anything. [...] Hillier was the bluff [Newfoundlander] who was going to set a difference." ${ }^{468}$

The implementation of the Conservatives' "Canada First" defence policy would spark further tensions between Defence Minister O'Conner and Gen. Hillier, in 2007. The Conservative campaign pledge to create 14 "territorial defence battalions" was met with opposition by the Chief of the Defence Staff, who promoted instead the idea of larger contingents to be sent to Afghanistan: "we have sufficient [territorial] units ... we don't need new units. ${ }^{469}$ In return, Mr. O'Connor "has infuriated the brass," according to media reports, "by demanding that Hillier plan for the questionable deployment of a rapidreaction battalion to Goose Bay, N.L., and the relocation of the Joint Task Force Two to

${ }^{467}$ Gloria Galloway, "Controversy takes flight on $\$ 8.3$-billion plan for planes," The Globe and Mail, June $30,2006$.

${ }^{468}$ As quoted in "Ottawa seeks closer watch on top general," by Michael den Tendt, The Globe and Mail, April 19, 2006.

${ }_{469}^{* * *}$, "Harper must deal with Hillier and O'Connor," The Intelligencer, August 2, 2007. 
Trenton, Ont., which seems more to do with electioneering than legitimate military manoeuvres." ${ }^{470}$ The government realized it was forced into a defensive position in its dispute with military brass over aspects of defence transformation and decided, in the summer of 2006, to underscore its pre-eminence over key decisions in the area of military affairs. Among others - as indicated earlier in this chapter - Gen. Hillier was asked to run his speeches by the Defence Minister's office and the Government committed itself to sending out clearer messages on its expectations related to defence transformation. In the end, as Lagassé and Sokolsky indicated, Gen. Hillier's positions led to "mixed, but telling, results. Though $\mathrm{O}^{\prime}$ Connor succeeded in prioritizing the acquisition of strategic airlifters, the government diluted its arctic defence proposals and no urban consequence management units materialized., ${ }^{, 41}$

In many cases of disagreement over main aspects of the transformation process, political leaders did not seem able to fully impose their viewpoints over their military counterparts. Faced with a worsening security situation in Afghanistan (Canada's only military intervention overseas at that moment), coupled with anxiety about lack of majority political support in Parliament, the Martin and Harper government were reluctant to further antagonize the country's armed forces - especially when they started to be perceived as Canada's first political forces following the end of the Cold War to take the military's concerns seriously. Conflicts occurring over military procurement, for instance, are relevant to the analysis of civil-military relations in the area of defence transformation. The assessment of these tensions provides evidence for a partial inability

\footnotetext{
${ }^{470}$ Don Martin, "Showdown over military's direction rankles top general," The Gazette, February 16, 2007.

${ }^{471}$ Philippe Lagassé and Joel Sokolsky, "A Larger 'Footprint' in Ottawa."
} 
on the part of Canada's political establishment to fully shape today's Canadian Forces and their future evolution; after years of perceived neglect, the military was determined to advance its agenda, even it meant upsetting its civilian masters.

\section{V.2.e. Canada-United States defence relations}

The importance of strong relations with the United States cannot be overemphasized in Canada; genuinely disliked or unconditionally accepted, close US-Canada relations are a fact of life and their impact is felt in a wide array of areas. In the field of security and defence, US-Canada relations are some of the strongest such bilateral links in the world's recent history. This occurs, as Norman Hillmer pointed out, in a context in which "[e]ighty-five percent of our foreign policy resides in our relations with the United States. That is the brutal fact, and that is the interest we most zealously and effectively protect. ${ }^{\text {472 }}$ As indicated in Chapter IV of this thesis, Canadian military and civilian leaders alike have largely agreed that it is in the country's best interest to maintain and increase the level of defence cooperation with the United States.

While this principle has been accepted by Canada's political and military authorities, some patterns can be identified in their approach to this issue: top military brass tend to unreservedly promote US-Canada defence relations, while civilian officials are more cautious in their positions. This area is highly relevant to civil-military relations given the fact that, as Janice Goss Stein and Eugene Lang pointed out, "Canada's generals and admirals tend to be more concerned about their relationships with their American

${ }^{472}$ Norman Hillmer, "The secret life of Canadian foreign policy," Policy Options, February 2005, 33. 
counterparts than they are with their own political masters in Ottawa." ${ }^{, 473}$ The armed forces perceive increased cooperation with the US military as highly beneficial to defence readiness and professionalism, whereas political leaders are at the same time concerned about being perceived by their supporters as "too cozy" with the United States. The manifest civil-military tension reached unexpected levels during the period covered by this study in relation to Canada's proposed participation in the United States' National Missile Defense program.

On the military side, senior leaders perceived the changing treat environment as a period offering the chance of renewal for the country's armed forces; in this context, better interoperability with the United States military and participation in a growing number of joint programs were seen by high-ranking officers in the Canadian Forces as an important opportunity for institutional rejuvenation. As indicated in previous chapters of this thesis, the Canadian Forces had gone through what some military leaders, including Chief of the Defence Staff Gen. Rick Hillier, called "a decade of darkness." The possibility of participating in a continental and possibly global defence program, as a key player given their unique status in NORAD, convinced military leaders of the strategic importance of Canadian involvement in the NMD project.

On the other side of this divide, Canada was just entering a period of political flux, with a series of federal minority governments (following the elections of 2004); and the country's civilian leaders were reluctant to commit to stronger relations with the United States, given key segments of the electorate opposing this idea. With Quebec as an

${ }^{473}$ Janice Gross Stein and Eugene Lang, 14. 
important electoral battleground and a large section of the Canadian public strongly opposed to newly emerged US policies in the "war on terror" (e.g., the US-led invasion of Iraq), politicians did not want to be perceived as giving in to US demands in the area of security and defence. While the Cabinet proposed a wait-and-see policy vis-à-vis missile defence plans for North America, military leaders, on the other hand, were keen to capitalize on a rapidly closing window of opportunity to strengthen links with the world's largest military establishment.

As Hugh Segal put it in early 2002, referring to differences in the civilian and the military approach to Canada-US defence relations, "[t]he issue of relative size, capacity and proximity make military conclusions about cooperation and interoperability almost selfevident. The politics of those conclusions are, of course, quite problematic." ${ }^{474}$ On the issue of Canadian participation in the National Missile Defense initiative, even Canada's Ministers of National Defence have largely supported the idea; their political bosses, however, the Prime Ministers, have generally been reluctant supporting openly this initiative, mainly for electoral reasons.

Defence Minister John McCallum and Defence Minister Bill Graham were, post-9/11, two of the most vocal supporters of Canada-US cooperation on this file. "While no decision has been made," Mr. McCallum said in November 2003, I believe Canadians are better off 'inside the tent." "475 Another advocate for Canada's participation in the NMD

\footnotetext{
${ }^{474}$ Hugh Segal, "The Canadian-American Defence Relationship: Nostalgia Ain't What It Used to Be," Policy Options, vol. 23, no. 3 (April 2002), 23.

475 ***, "Speaking Notes for The Honourable John McCallum, P.C., M.P. Minister of National Defence at the Standing Committee on National Defence and Veterans Affairs,"
} 
system, Mr. Graham noted that there was a "long tradition of Canada and the United States working together on the defence of North America, because it's in our interest [...] if one is attacked, the other is at risk" ${ }^{\prime 476}$ - in September 2004, he called the NMD system "an important program in the context of Canadian-American relations." in this debate proved to be inconsequential, as final decisions were made by Prime Ministers, particularly Paul Martin, leading to Canada declining to join the proposed continental program.

Mr. McCallum's and Mr. Graham's comments were made in a context in which the governing Liberals were reluctant to commit to stronger relations with the United States for fear of electoral reprimand. The events of September 11, 2001, did not radically change their position on this file, both Prime Minister Jean Chrétien and Prime Minister Paul Martin trying to avoid substantive discussions on Canada's participation in the NMD system. Describing the domestic political context at the time, a National Post editorial noted: "[g]iven the anti-Americanism that infects Canadian political life [...] posturing against America has been embraced as a more important goal than protecting Canadian lives." ${ }^{, 478}$ Prime Minister Chrétien had already been opposed to stronger Canada-US relations prior to the debate on a NMD system; as Opposition leader, for instance, he had opposed forceful involvement of Canadian troops in the 1991 US-led Gulf War.

http://www.forces.gc.ca/site/Newsroom/view news e.asp?id=1252, November 6, 2003 (accessed March 22, 2007).

${ }^{476}$ Andrew Richter, "Towards a More Strategic Future? An Examination of the Canadian Government's Recent Defence Policy Statements," Canadian Military Journal, vol. 7, no. 1 (Spring 2006), 36. 477 ***, "Missile defence talks important for Canada: Graham," CBC News, September 23, 2004. 478 ***, "Fresh thinking on missile defence," National Post, January 16, 2006. 
While Prime Minister Martin oscillated between maintaining a similar position vis-à-vis the United States and a new policy of rapprochement, he was not only concerned about the public's perception of his decisions, but also about dissent in his party's caucus. After sending out a series of contradictory messages, Mr. Martin said, in December 2004: 'I'm not going to put money into it. I'm going to put money into our priorities. [...] Having missiles on our territory is not one of those priorities. ${ }^{, 479}$ During the period covered by this study, Prime Minister Stephen Harper would not commit to Canadian participation in the NMD system either.

With a political establishment fixated on the electoral cost of strengthening defence relations with the United States, Canada's Department of National Defence was still going ahead with plans to reach an agreement with its US counterparts on cooperation in the NMD framework. According to a March 2004 briefing note by DND's policy branch, "Canada sees its participation in [NMD] as being anchored in NORAD, which has for almost 50 years been an integral part of our partnership in the defence of North America"; in February 2004, another DND briefing note argued that Canada "wants to continue to work closely with the U.S., as we have done for over 60 years, in the defence of the continent. [NMD] will build on this co-operation." ${ }^{\text {480 }}$ The defence establishment argued that Canadian participation in the US National Missile Defense framework was worthwhile and would strengthen, rather than compromise, national sovereignty, by providing Canada with additional access to security and defence resources. According to

479 Robert Fife, "Budget to include funds for Armed Forces to recruit 5,000 troops," Ottawa Citizen, December 15, 2004.

${ }_{480}$ Mike Blanchfield, "Canada told U.S. in June it backs missile shield," Ottawa Citizen, January 14, 2005. 
a senior civil servant, cited anonymously by Janice Gross Stein and Eugene Lang, some Canadian military leaders worked with their US counterparts to lobby the Government to join the NMD project: “[i]t's unthinkable for the Canadian Forces ... to behave that way."481

Uniformed and civilian DND officials argued for the integration of NMD structures within the NORAD framework, which would automatically allow Canada to work alongside the United States on this project. The Department of National Defence and the Department of Foreign Affairs and International Trade negotiated intensely during the 2003-2004 period the terms of Canada's participation in the system. When the country's political leaders announced the decision not to be part of the NMD framework, the defence establishment's reaction was unmistakably negative. In the words of Vincent Rigby, then-Director General for Policy and Planning at DND, civilian and uniformed personnel at the National Defence Headquarters were frustrated by that turn of events: “there was disappointment, after we tried so hard and we worked with the Americans to that point. [...] There was disappointment, we're going to leave it at that. [...] What it did disappoint a lot of people inside the Department is that $[. .$.$] we never had a chance to$ have a public debate. ${ }^{~} 482$ In late 2006 , the Conservative government would announce it had no plans to reopen the US ballistic missile defence system debate, despite a Senate defence committee recommendation to sign on. ${ }^{483}$

\footnotetext{
481 Janice Gross Stein and Eugene Lang, 261.

${ }^{482}$ Vincent Rigby, presentation at the conference Terrorism, Democracy and Empire, Carleton University, Ottawa, October 1, 2005.

${ }^{483}$ Kathleen Harris, "Tories shoot down missile defence," The Ottawa Sun, October 6, 2006.
} 
Despite such roadblocks, the military pushed for the extension of the North American Aerospace Defence Command's competencies in the area of maritime surveillance, while leaving open the possibility of future Canadian participation in the NMD system through NORAD. Top military officers and political figures were also strongly behind closer Canada-US defence collaboration in Afghanistan and promoting increased participation in bilateral and multilateral military exercises. At a time when the country's political leadership seemed to purposefully distance itself from the image of close supporter of the United States military and US foreign policy goals, Canada's military and political leaders were in fact actively involved in improving the stature of Canadian Forces at home and abroad; one of the ways to achieve that objective was through stronger links to US forces, which they pursued forcefully. On this file, civilians were largely able to impose their preferences upon their military counterparts; while military leaders promoted their agenda of strengthening Canada-US defence relations with relative success, when policy disagreements occurred civilians proved able to define the scope of that collaboration.

\section{V.2.f. Military responses}

As the most important (if not the only significant) military engagement of Canada's in the post-9/11 era, Afghanistan sheds further light on national patterns of civil-military interaction. The next paragraphs will provide evidence for tense civil-military relations, which stands to support the main argument of this thesis - uncertainty over optimal responses to a new and unstructured threat environment, combined with the risk of 
drawing the country into a very dangerous war zone with no exist strategy in sight, led to complex patterns of civil-military affairs. Three stages can be identified during the 20012006 period, each with its own distinct characteristics, corresponding with the tenures of Prime Ministers Jean Chrétien, Paul Martin and Stephen Harper. (On the military side, Mr. Chrétien's Chief of the Defence Staff was Gen. Ray Henault, Mr. Harper's CDS was Gen. Rick Hillier, while Mr. Martin worked with both generals).

Prime Minister Chrétien, for instance, pushed through the idea of larger contingents of Canadian troops being sent to Afghanistan in 2003 against the advice of the country's military leaders; Prime Minister Martin struggled to define his government's position on Afghanistan during a time of transition within the office of the Chief of the Defence Staff; while Prime Minister Harper, a supporter of the Canadian effort in Afghanistan, had to ask his CDS to moderate his pro-war positions. None of the three Cabinet leaders enjoyed harmonious relations with top military brass on the topic of Afghanistan, although there were degrees of divergence that will be explored further.

While being praised by analysts and foreign counterparts for his willingness to provide active support to the newly discovered war against international terrorism, Prime Minister Chrétien sent around 2,000 Canadian troops to Afghanistan in early 2003 despite the opposition of his own military advisors. It was the second major Canadian deployment to Afghanistan in as many years, meant to assist the US-led international coalition in a complex effort to annihilate Taliban insurgents and al-Qaeda militants, and to create conditions for this Asian country's transition to democracy and stable government. 
Observers of Mr. Chrétien's activity in office generally agree that his decision to deploy Canadian troops to Afghanistan in a significant role was driven by his desire to avoid a positive decision on deployment to Iraq, in the months prior to the US-led attack on Saddam Hussein's regime. Yet senior military leaders have openly expressed their disagreement both prior to and after the official announcement that a Canadian army battle group and a brigade headquarters would be sent to Afghanistan. Top military brass argued that the Canadian Forces had to recover after the 2002 deployment and that the limited resources they were given made the recovery painfully slow. In an analysis of this episode, Douglas L. Bland and Roy Rempel show that the armed forces' leaders were concerned that "such a deployment would have a serious and negative long-term impact on future army operations. ${ }^{.484}$

Maj.-Gen. Cam Ross, Director General for International Security Policy at DND, resigned in protest over the redeployment issue, while Lt.-Gen. Mike Jeffrey, Chief of the Land Staff, said his troops were not ready for a major external mission. "I could see Canadian soldiers dying, because they weren't properly prepared. [...] the risks were too high," Lt.-Gen. Jeffrey told CBC. ${ }^{485}$ In an interview for National Network News, he argued that his opposition was fuelled by the fact that "the military establishment [...] was already tired, stretched to the maximum," while the "political objectives [for the Afghan mission] were less than clear" - "[t]o my mind this was a high risk operation that

\footnotetext{
${ }^{484}$ Douglas L. Bland and Roy Rempel, "A Vigilant Parliament," 29.

485 ***, "Chrétien government rejected military's advice on Afghan deployment: ex-army chief," $C B C$ News, October 18, 2006.
} 
[...] I frankly questioned. ${ }^{, 486}$ Chief of the Defence Staff Gen. Henault reportedly opposed the idea of a significant overseas deployment, although - consistent with previous interaction with his civilian masters - he did not voice his apprehension publicly (he did not throw his weight behind the plan either). As a response to these military positions, a former senior official in the Prime Minister's Office, Eddie Goldenberg, pointed out that, customarily, "Governments decide where the military goes, the military doesn't decide where it goes." ${ }^{.487}$

On the civilian side, Minister of National Defence John McCallum presented the Afghan deployment as the country's military contribution to the war against terrorism: "the Afghanistan mission is right for Canada. ${ }^{488}$ In the end, the 2003 deployment to Kabul was decided by the country's political leaders and "imposed on the military." 489 The civil-military rift exposed by this episode reveals broken channels of communication between the two sides (going into Mr. Martin's tenure as Prime Minister) and an inability to reach viable compromises over difficult security and defence questions. One of the few military leaders that had supported the Afghanistan mission was Gen. Rick Hillier, later to be promoted Chief of the Land Staff and commander of the International Security Assistance Force in Kabul. While his approval of the deployment is said to have contributed to his swift rise in the defence hierarchy at a time when the Government was in need of sympathetic military voices, a Maclean's analysis also reveals that for Gen.

\footnotetext{
${ }^{486}$ Interview with LGen (ret'd) Mike Jeffrey, National Network News.

487 ***, "Chrétien government rejected military's advice on Afghan deployment: ex-army chief."

488 John Geddes, "Bullets fly. Ottawa ducks," Maclean's, August 28, 2006, 23.

${ }^{489}$ Interview with Kenneth Calder, by the author.
} 
Hillier "serving in Afghanistan seems to have left a deep personal and professional impression. He emerged as a driving force behind Canada's Afghan commitment. ${ }^{, 490}$

Once Gen. Hillier was appointed Chief of the Defence Staff by Paul Martin, the country's new Prime Minister, the roles shifted in the civil-military relationship. Whereas the Chrétien-Henault interaction revealed a civilian side managing to impose most of its decisions over a reluctant military leadership, the Martin-Hillier relationship inclined the balance in the military's favour. With an increasing number of critics accusing Prime Minister Martin of indecisiveness on his Government's key files (the influential British magazine The Economist labelling him "Mr. Dithers"491), Gen. Hillier emerged as the country's most significant voice on security and defence issues. He convinced the Prime Minister to commit Canadian troops to one of the most dangerous areas in Afghanistan, the Kandahar region, and suggested, along with other senior defence leaders, that the Canadian presence in this Asian country would be long-term. (The Harper-Hillier relationship would see civilian oversight over the armed forces restored to some extent).

According to defence analyst David Pugliese, besides the official goal of Canada's presence in Afghanistan, i.e., the country's reconstruction, "the general had other motives [...]. A combat mission in Kandahar fit into Gen. Hillier's vision of the Canadian Forces. That future would involve direct military intervention if necessary to stabilize failed or failing states" - the more intense the theatre security situation, the better equipped and

\footnotetext{
${ }^{490} \mathrm{Ibid}$.

491 ***, "The uncertain leadership of Canada's Paul Martin," The Economist, February 17, 2005.
} 
prepared the Canadian Forces would have to be. ${ }^{492}$ For a significant period of time, well into the next Prime Minister's tenure, it was Chief of the Defence Staff Gen. Hillier setting the country's direction on security and defence issues and proposing timelines for the Canadian Forces' Asian engagement. The Afghanistan mission became Gen. Hillier's war even more than it became Prime Minister Martin's war or Mr. Harper's. Canada's new government would, however, challenge Gen. Hillier's virtual monopoly over the country's security and defence file and rebalance the civil-military relationship.

For the first few months after Mr. Harper's Conservatives took over the reigns of power in Ottawa (in early 2006), Gen. Hillier continued his campaign of vigorous promotion of the Afghanistan mission and active engagement into the policy arena. In the fever of putting together "Canada's New Government," Prime Minister Harper left the Chief of the Defence Staff in control over the country's most important military engagement in recent decades. Gen. Hillier joined a chorus of other military leaders who argued that Canadian troops would need to stay in Afghanistan for at least a decade (he would reassert this position in 2007). Even Minister of Foreign Affairs Peter MacKay seemed unwilling to challenge the armed forces growing control over this file: "[ $[$ t]he length of Canada's military commitment in Afghanistan is an 'open question' to be determined in large part by generals," Mr. MacKay said in March 2006. ${ }^{493}$

However, as the head of a minority government and faced with unsteady electoral support, Prime Minister Harper had to step in and make clear that "decisions on

\footnotetext{
492 David Pugliese, "From peacekeepers to Taliban hunters," Ottawa Citizen, March 25, 2006.

493 ***, "Generals will determine Afghan stay: MacKay," Toronto Star, March 6, 2006.
} 
deployments are always made in the end by the civilian authorities, the elected democratic authority of the country." 494 The statement, coupled shortly after with the request that the CDS check his public statements with the Minister of National Defence, reinstated civilian leaders in a control position vis-à-vis the country's military. Nonetheless, Gen. (ret'd) Lewis MacKenzie expressed what many thought about these civil-military tensions: "the public perception of difference has created confusion and undermined support for the mission in Afghanistan." ${ }^{, 495}$ The episode only increased public awareness over the complex picture surrounding Canada's intervention in Afghanistan. The government seemed rather unable to define the end goal of the mission and its expected length. "You'd have to be clairvoyant to imagine how long these things are going to go on. [...] We don't have any conception at the moment in terms of length of time," Minister of National Defence Gordon O'Connor told the media. ${ }^{496}$

Civilian authorities started gradually losing credibility in the face of an increasingly sceptical public - neither the Government, nor the armed forces (not the latter's task, in the first place) could answer the many serious questions relating to this mission. How long will the Canadian troops stay in Afghanistan? What is the nature of the mission? What are the end-state conditions to declare the mission a success? What situations would determine the Government to bring the troops home even when they would be far from achieving their final objectives? And - maybe the two most important questions "why Afghanistan?" and "what is the exit strategy?" By late 2006, these questions

\footnotetext{
${ }^{494}$ Mike Blanchfield, "Government, not generals, will decide mission: Harper," National Post, March 8, 2006.

495 ***, "O'Connor, Hillier out of step on issues: critics," CTV News, July 31, 2007.

${ }^{496}$ John Geddes, "Canada in Combat," Maclean's, March 20, 2006, 23.
} 
remained unanswered; in early 2008 an "Independent Panel on Canada's Future Role in Afghanistan," led by former Deputy Prime Minister and Minister of Foreign Affairs John Manley, produced a report that addressed many of these questions. ${ }^{497}$

In 2007, a controversy erupted over the treatment of Afghan detainees handed over by Canadian forces to Afghan authorities during the course of the mission, in previous years. According to media reports, detainees said they were beaten, tortured and generally mistreated while in custody, which led to a frenzy of positions from both civilian and military officials in Canada. According to a DND source, cited by The Hill Times, the armed forces "never saw the detainees as a problem [...]. They saw them as a nuisance that would blow up in the press from time to time"; the military reached a late 2005 agreement with Afghan authorities on the transfer of prisoners, signed by Gen. Hillier, with little civilian supervision. ${ }^{498}$

The media and many analysts noted that, while the agreement was finalized toward the end of the Martin administration, Conservative Defence Minister O'Connor didn't understand its implications and, consequently, had to apologize to Parliament for several inaccuracies presented on this issue. James Travers pointed out that the episode highlighted the "profound military resistance to civilian control," compounded by the appointment of Mr. O'Connor as Minister of National Defence ("a political embarrassment") and the Harper administration's use of Afghanistan as "a wedge

\footnotetext{
${ }^{497}$ Independent Panel on Canada's Future Role in Afghanistan, http://www.independent-panelindependant.ca/main-eng.html, January 2008 (accessed February 2, 2008).

498 James Travers, "PM uses Afghanistan mission as a wedge political issue," The Hill Times, April 30, 2007.
} 
political issue." ${ }^{, 499}$ Janice Gross Stein and Eugene Lang also argued that Gen. Hillier's decision to sign an agreement with the Afghan government with little civilian supervision (in the context of an election campaign at home) "is one more troubling example of the weak civilian oversight of Canada's military.",500

Overall, Canada's military engagement in Afghanistan revealed a general inability on the part of the country's civilian authority to provide solid expertise on security and defence matters and to be in full control over their armed forces. When they did manage to impose their positions (e.g., Mr. Chrétien's decision on military deployment to Afghanistan or Mr. Harper reclaiming authority over the Afghanistan file) civilian leaders had to balance military-related decisions against the complex background of political considerations. Col. D. Craig Hilton pointed in 2007 to "a strategy vacuum" - "a critical deficiency" that was "present from the outset" which, "if left unchecked, will continue to threaten the strategic coherence and operational success of Canada's present undertaking and those others that undoubtedly lie ahead."

Other times, it was the military advancing proactively its own institutional agenda, even when it meant reaching far into the policy realm (e.g., during most of Mr. Martin's short term as Canada's Prime Minister). Gen. Hillier's leadership - as Gross Stein and Lang put it - "because it [was] so strong, so strategic, and so focused [...] unbalanced the relationship between civilians and the military [...] some allege that Canada's military

499 Ibid.

${ }^{500}$ Janice Gross Stein and Eugene Lang, 254.

501 Col. D. Craig Hilton, "Shaping Commitment: Resolving Canada's Strategy Gap in Afghanistan and Beyond." 
now lacks sufficient civilian oversight." ${ }^{502}$ Afghanistan in particular presented us with an ambiguous civil-military relations picture - one in which civilian leaders tried to reclaim ownership over a file they rarely saw as worthy of attention, except in those cases when they saw their legitimate authority undermined by an increasingly vigorous military establishment.

\title{
V.3. Civil-military relations in Romania
}

\author{
V.3.a. Introduction
}

\section{V.3.a.i. General overview}

The Romanian Armed Forces' involvement in the country's political debates since the revolutionary events of 1989 has suggested not a risk of military coup - as some analysts feared in the early $1990 \mathrm{~s}$ - but a tendency on the part of the military establishment to express public views and to shape the official discussion on key security and defence matters. Especially in a fluid political environment and in a European area where military establishments traditionally provided the expertise on defence matters, the Romanian military attempted to consolidate its position within the state apparatus. At the same time, the country's politicians often attempted to use the armed forces for partisan political games, i.e., trying to enlist military support in political conflicts with their opponents or the media.

${ }^{502}$ Janice Gross Stein and Eugene Lang, 260. 
While civilian control over the military had been strong before the revolutionary events of 1989, the post-Cold War transformation of the Romanian defence establishment involved numerous arguments between civilians and the military. By trying to impose stronger control over the terms of the debate and the scope of this process, civilian leaders often antagonized their military counterparts. Many experts tend to agree that tight measures of civilian oversight of the military were implemented in Romania, as in most Central and Eastern European countries, given external organizations such as the North Atlantic Treaty Organization and (to a lesser extent) the European Union having defined them as basic conditions for accession; such measures had a mixed rate of success. Marina Caparini noted that governments in the region "have been accused of valuing civilian control mainly as a means to the end of NATO membership, rather than inherently attaching value to the concept as a hallmark of democracy."

Since 1989, although recognizing - in a qualitatively different international context - the need for civilians to act as the country's legitimate decision makers in the areas of security and defence, the Romanian armed forces have retained a significant degree of autonomy in military affairs. They opposed inquiries into their internal affairs, but also in relation to the military's involvement in various events of high relevance for the Romanian society, including the 1989 political changes. By opposing closer examination of such episodes, the armed forces attempted in fact to maintain the post-Cold War status quo, which involved cohabitation and respect for civilian leaders, but not full control by politicians over military matters.

\footnotetext{
${ }^{503}$ Marina Caparini, "The Challenge of Establishing Democratic Civilian Control Over the Armed Forces of Central and Eastern Europe," Canadian Defence Quarterly, vol. 2, no. 2 (Winter 1997), 23.
} 
This has led to a situation in which, as Larry Watts argues, "the military was to bear the brunt of the reform and restructuring. [...] Assigning the military the lead in the process also stemmed additional civil-military frictions, since neither the reforms nor the manner of their implementation seemed to have been 'imposed' from outside." 504 Specific problems in post-Cold War and post-9/11 civil-military relations in Romania will be investigated later in this chapter. The following section will offer a short overview of institutions that play a key role in Romania's security and defence arena.

\section{V.3.a.ii. Roles and functions}

The Cabinet of Romania

According to the country's legal framework, the Cabinet of Romania (or, colloquially, "Government of Romania") is the state's main executive branch, in charge of shaping and implementing domestic and foreign policies, and exercising the general management of the national public administration system. Its departments (called ministries), including the Ministry of National Defence (MApN), are organized based on the principle of subordination to the Cabinet only. The Romanian Constitution notes that, in the area of security and defence, the Cabinet initiates legislation, submits draft defence budgets to Parliament, negotiates treaties and agreements on international cooperation and, with

\footnotetext{
${ }^{504}$ Larry L. Watts, "The Crisis in Romanian Civil-Military Relations," Problems of Post-Communism, vol. 48, no. 4 (July/August 2001), 15.
} 
prior parliamentary approval, allocates financial resources to the country's armed forces. $^{505}$

Headed by a Prime Minister (named by the party or coalition of parties holding the majority in Parliament), the Cabinet is formally accountable to Parliament and to the Supreme Council of National Defence (CSAT); in fact, the Cabinet makes most security and defence-related decisions without broader consultation and with little external oversight. Formally, Cabinet ministers are held accountable for the activity in their area of responsibility and the Cabinet is accountable as a whole to Parliament. MApN is chiefly responsible for setting up and implementing the country's main defence policies; in conducting its activity, the Ministry of National Defence may cooperate with other government departments, with other national and local public administration bodies, and with nongovernmental organizations.

The Ministry of National Defence analyzes and proposes to CSAT, for formal approval, appropriate measures in relation to the country's strategic defence needs, organizes military units in peacetime, prepares draft defence budgets, supervises budgetary implementation in its sphere of competence, and makes and enforces decisions on the armed forces' overarching organization. The first civilian Minister of National Defence was appointed in post-Communist Romania in 1994 (Gheorghe Tinca); since then, the position has continuously been held by civilians. Along with the Prime Minister, the

\footnotetext{
${ }^{505}$ Parlamentul Romaniei, Constitutia Romaniei, http://www.cdep.ro/pls/dic/site.page?id=339, 2003 (accessed May 23, 2007).
} 
Minister of National Defence exercises control over the armed forces via the office of the Chief of the General Staff (the equivalent of Canada's Chief of the Defence Staff).

The Romanian Armed Forces

Similar to the role of the Canadian Forces and other Western military establishments, the Romanian Armed Forces (called, at times, the "Romanian Army") are in charge of providing military security, based on policies and strategies set up by the country's civilian authorities. The armed forces' General Staff is responsible for the operational and military command of the units; it is subordinated, through the Chief of the General Staff, to the Ministry of National Defence. At all times, the MApN command is exercised by the civilian Minister of National Defence, who represents his/her organization in relations with other government departments and external bodies.

The Chief of the General Staff, the highest defence authority, is the main military adviser to the Minister of National Defence and the Prime Minister, but also to the President of Romania and the Supreme Council of National Defence. (In wartime - i.e., when a declaration of war is formally passed by Parliament - the management of strategic military actions becomes the responsibility of a Grand General Staff, headed by a military officer named by the President based on a proposal from the Minister of National Defence). During the post-Cold War period, the General Staff has become better integrated within MApN, but military leaders have retained a high degree of power in decision-making processes. 
The President of Romania

The President of Romania represents the Romanian state, is the Commander-in-Chief of the Romanian Armed Forces and presides over the Supreme Council of National Defence. The President may declare, with prior approval by Parliament, partial or general mobilization of the armed forces and may institute the state of siege or emergency. $\mathrm{He} /$ she designates a candidate to the position of Prime Minister, appoints the Cabinet based on a vote of confidence by Parliament and may preside over Cabinet on matters of national interest, including security and defence issues. The President has the power to award official decorations and titles of honour, and to make promotions to the military ranks of Marshal, General and Admiral.

As Head of State in a semi-presidential political system, the President of Romania has a less important role in peacetime than Parliament or the Cabinet in the areas of security and defence. The fact that the President may declare armed mobilization only with prior approval by Parliament and that the declaration has to be initially agreed upon by CSAT exemplifies adequately the Romanian President's position in the country's system of military oversight. As a general rule, the President's prerogatives in the defence realm are carried out subject to approval by Parliament.

As the Cabinet is formed based on the relative weight of political parties in Parliament, this framework places the Cabinet in a more influential position than the President. 
His/her "functions are circumscribed to the sphere of the executive power and, accordingly, their exercise is being divided between the President and the [Cabinet], both authorities under parliamentary control. [...] In the overwhelming majority, these are subject to the [Cabinet's] or Parliament's consent. ${ }^{" 506}$ Conflicts between the President and the Cabinet (i.e., the Prime Minister) can lead to political deadlock, yet in most cases it is the latter that carries the day.

The Supreme Council of National Defence

Romania's Supreme Council of National Defence, chaired by the President of Romania and comprising key government officials with responsibilities in the areas of security and defence (including the Minister of National Defence and the Chief of the General Staff), has an important role in the system of civilian control over the armed forces. It provides "an institutionalized forum to coordinate civilian and military thinking on the most pressing national security issues [and] to monitor the implementation of executive and governmental decisions affecting national security. ${ }^{~} 507$ While experts agree that its scope is very broad, CSAT is an institution virtually unaccountable to other state organizations or the society at large. It can make decisions, inter alia, on matters relating to the structure, composition and internal regulation of the organizations acting in the areas of security and defence, but also on international security agreements and participation in military operations.

506 Gheorghe Diaconescu et al., Democratic Control over the Army in Romania (Bucharest: Editura Enciclopedica, 1996), 154.

${ }^{507}$ Larry Watts, "Reform and Crisis in Romanian Civil-Military Relations: 1989-1999," Armed Forces and Society, vol. 27, no. 4 (Summer 2001), 602. 
When it was created in 1990, Parliament proposed for CSAT a role similar to that of the US National Security Council. Nonetheless, Romania's Supreme Council of National Defence became an entity that can regulate to a significant extent the fields of security and defence - thus, going beyond a predominantly consultative role, as initially designed. ${ }^{508}$ Although it has to report annually to the Parliament, "[a]s far as the nature, number and importance of [its] attributions are concerned, it has to be noted that all major issues coming within the ambit of national defence are taken up by [CSAT] - mandatory and prior to their examination by any other public authorities. ${ }^{.509}$

A 1996 study conducted by the Management and Consulting Services of the United Kingdom's Ministry of Defence ${ }^{510}$ recommended a re-evaluation of CSAT's responsibilities. The study suggested that the council's roles and functions are unjustifiably high, some of them duplicating other state institutions' responsibilities. A 2002 review of the law regulating the activity of the Supreme Council of National Defence brought no major changes to this legal document. ${ }^{511}$ While CSAT is at times perceived as duplicating the Cabinet's activity, it acts mainly as the institutional arena where the most important debates on security and defence matters take place and the backdrop against which civil-military differences are addressed.

\footnotetext{
${ }^{508}$ Liviu Muresan, "Security Sector Reform: An Opportunity for Euro-Atlantic Integration of Romania," DCAF Working Papers, no. 11 (April 2002), 10.

${ }^{509}$ Claudiu Degeratu, "Civil-Military Relations in Romania: Objectives and Priorities," in Civil-Military Relations in South-East Europe, ed. Plamen Pantev, (Vienna: Institut für Internationale Friedenssicherung, 2001), 161.

${ }^{510}$ M. Holmes, Studiu privind controlul parlamentar asupre Ministerului apararii nationale al Romaniei si controlul democratic asupra fortelor armate (Bucharest: Ministerul Apararii Nationale, 1997), 51.

${ }^{511}$ Anca Hriban, "Legea CSAT are forma dorita de Iliescu," ZIUA, June 19, 2002.
} 
The Parliament of Romania

Parliament is, according to the country's Constitution, the supreme representative body of the Romanian people and the sole legislative authority of the state. It comprises two chambers (the Senate and the Chamber of Deputies), which have important responsibilities in the areas of security and defence: Parliament may declare partial or general mobilization of the armed forces, declare a state of war, and suspend or cease armed hostilities. In addition to examining reports and recommendations from CSAT, the two parliamentary chambers include standing committees on Defence, Public Order and National Security and may institute commission of inquiry.

Laws are submitted for promulgation to the President, who can return them to Parliament for reconsideration. The fact that the President may only do so once for every single law illustrates the pre-eminence of Parliament vis-à-vis the President. Nonetheless, Parliament itself is in a less influential position as compared with the Cabinet - the locus of state decisions on security and defence matters. One of Parliament's main responsibilities in these areas is to assess and approve the draft defence budget; yet lack of expertise and continuity among parliamentary committee members often hamper Parliament's ability to influence this process, placing the organization in a rubberstamping position. 
This situation has led to increasingly influential roles for the Cabinet. In many instances following the end of the Cold War, the Cabinet has been able to bypass Parliament altogether, with no negative repercussions. Various Romanian Prime Ministers have exercised their powers by having their ministers pass so-called "emergency ordinances" in non-emergency circumstances; they have arguably avoided long and uncertain parliamentary debates, yet these have also undermined the country's democratic processes. The following subsection of this chapter will offer a more in-depth analysis of the extent to which the Parliament of Romania manages to exercise oversight over security and defence matters.

\section{V.3.a.iii. Parliamentary oversight}

Parliamentarians' general lack of expertise on military issues and continuity as part of the legislative assembly and/or the parliamentary defence committees has had a significant impact on Parliament's ability to influence the national debate on security and defence matters. In post-Communist Romania, only a relatively small number of parliamentarians (MPs) have represented their constituencies in more than one mandate. An analysis of MPs holding positions as Members of Parliament for a longer period of time reveals their relative lack of expertise in the areas of security and defence. This is noticeable - Marina Caparini pointed out - "in the absence of sustained or in-depth parliamentary debate on crucial defence issues and in the often low-prestige and acquiescent behaviour of parliamentary defence committees." ${ }^{\text {512 }}$ Not only that these committees consist of

\footnotetext{
${ }^{512}$ Marina Caparini, "The Challenge of Establishing Democratic Civilian Control Over the Armed Forces of Central and Eastern Europe," 18.
} 
insufficiently prepared MPs, but the staff affiliated to them are themselves usually unable to "undertake deeper analyses and independent assessments of defence issues." "513 Although meant to play a very important role in the oversight of armed forces, the Romanian legislature has been rather superficially involved in this process during the post-Cold War era.

Weak parliamentary control over the military and, generally, frail parliamentary involvement in debates on security and defence-related matters can also be explained by the limited audience for military issues and, consequently, by generally low parliamentary interest in this field. At the same time, while final control over defence budgets should give Parliament significant leverage over the Cabinet and the armed forces, Minister of National Defence Ioan Mircea Pascu noted that, "[i]n practice, the efficacy of this instrument is considerably reduced by a combination of mechanism restraints and limitations imposed by the general economic situation." ${ }^{.514}$ Parliament's rubber-stamping role - by no means a unique characteristic of Romania among Western nations - undermines the legislature's very essence in the country's political system.

With budgetary control as a weak instrument of influencing the military establishment and most parliamentarians uninterested in the area of security and defence, the Cabinet has been able to operate without the supervision assigned to Parliament by the Constitution of Romania. Larry Watts points out that, "after 1997, [...] a number of

\footnotetext{
${ }_{513}^{513} \mathrm{Ibid}, 18-19$.

514 Ioan Mircea Pascu, "Parliamentary Control over the Military," in Romania and Euro-Atlantic Integration, ed. Kurt W. Treptow and Mihai Ionescu (Oxford: The Center for Romanian Studies, 1999), 116.
} 
procurement scandals suggest that civilian defense officials were evading normal [parliamentary] channels of monitoring and control."515 While the country' main legislative institution tries to improve its record in the area of defence oversight, it is the Cabinet that remains the locus of decisions in military-related matters.

\section{V.3.a.iv. Four political regimes}

The uprising of December 1989 was a momentous experience for Romania - it represented a radical break with its Communist past and, as Romanians saw it, an opportunity for reintegration within "Europe" and the West. Although controversial when it came to the involvement of second-tier Communist elites in the revolutionary unwinding - the events of that fateful December made the previous political order obsolete and planted the seeds for the country's rebirth. Many analysts have discussed the important role played by the Romanian armed forces in overthrowing the previous regime, by their decision to side with the anti-Communist forces after briefly defending the existing order. Marian Zulean, a fine observer of Romanian security and defence issues, notes that military participation in the events of 1989 left a double inheritance for the country's civil-military relations: "[o]n the one hand, [it] created a diffuse sentiment of guilt among the officers, this fact reducing their opposition to the setting up of new civilian control. On the other hand, the army's coalition with the civilian population contributed to the victory of the Revolution, raised the respect for the army and offered legitimacy for the internal reform process." 516

\footnotetext{
${ }^{515}$ Larry Watts, "Reform and Crisis in Romanian Civil-Military Relations: 1989-1999," 608.

${ }^{516}$ Marian Zulean, Armata si societatea in tranzitie (Bucharest: Tritonic, 2003), 170.
} 
From December 1989 until the elections of late 1996, the country's main political figure was President Ion Iliescu, a former Communist apparatchik who, behind the scenes, had led the uprising against dictator Nicolae Ceausescu's regime. Prime Ministers Petre Roman (1989-1991), Teodor Stolojan (1991-1992) and Nicolae Vacaroiu (1992-1996) representing the National Salvation Front (FSN) and, later, the Social Democracy Party of Romania (PDSR) - were secondary political figures in a country still approving of a strong head of state. Despite President Iliescu's apparent desire to strengthen civilian control over the military, the process proved to be complex and controversial. Coupled with a strategy of de-Communization and downsizing of the armed forces, the political changes at the top of the military hierarchy led to a severe crisis as early as 1990 .

President Iliescu's decision to reactivate Gen. (ret'd) Nicolae Militaru as Minister of National Defence in an attempt to ensure tighter control over the military establishment was opposed by an ad-hoc Action Committee for the Democratization of the Army (CADA). Composed of mostly active military officers, CADA promoted the idea of a change in the first post-Communist Government's policy vis-à-vis the armed forces, by rejecting the appointment or continuity as top military brass and civilian leaders of figures allegedly compromised during the Communist regime. Pressed by about 1,000 soldiers protesting in front of the Government building and embarrassed by an open conflict between CADA leaders and the new Minister of National Defence, President Iliescu asked for the resignation of Gen. Militaru. ${ }^{517}$

\footnotetext{
${ }^{517}$ Larry L. Watts, "The Romanian Army in the December Revolution and Beyond," in Romania after Tyranny, ed. Daniel N. Nelson (Boulder, CO: Westwiew Press, 1992), 98-99.
} 
The episode left the armed forces in a status-quo position and served as a reminder of the difficulty of pushing changes when faced with many, often opposing interests. For most of the 1990-1996 period, proposals for "de-Communization" and downsizing of the Romanian armed forces, as well as strengthening civilian control over the military, have been slow coming and even harder to implement. What Larry L. Watts calls a "sharedresponsibility" model of civil-military relations, characterizing Romania from 1990 until 1996, was rather a systemic inability of the actors involved to move forward. ${ }^{518}$ Not even external factors, such as the North Atlantic Treaty Organization or the European Union (which collectively would play a larger role in late 1990s and early this decade), were sufficiently strong to challenge the status-quo.

Gheorghe Tinca became the country's first civilian Minister of National Defence (appointed in 1994), yet the vast majority of top MApN positions were still occupied by military personnel. Military de-Communization started to become obsolete as a strategy and somewhat out-of-touch with the day-to-day activities of the armed forces, while downsizing was only pursued reluctantly. Lack of proper funding and civil-military and intra-military frictions further contributed to a sense of crisis within the defence establishment.

The elections of 1996 brought about the first major political change in post-Communist Romania, driving to the levers of power a right-of-centre political coalition, made up of the Democratic Convention of Romania (CDR), the Democratic Party (PD) and the ${ }^{518}$ Larry L. Watts, "The Crisis in Romanian Civil-Military Relations," 15. 
Democratic Union of Hungarians in Romania (UDMR). Ironically, what was initially expected to be a U-turn in the welfare of the military and a major boost for stronger civilian control over the armed forces never fully materialized - the new political coalition proved to be concerned more with infighting rather than security and defence issues. Military transformation was recognized by all major parties as a national priority, yet lack of proper funding, political will and clear roadmaps impeded the process. President Emil Constantinescu complained repeatedly toward the end of his mandate (1997-2000) that forces linked to the former Communist regime undermined his efforts for systemic transformation of the Romanian state; in fact, there were to a larger extent the quarrels within the coalition that supported his drive to power that played a negative role during those four years.

NATO started to exercise a degree on influence over domestic policies on the military only during the second half of President Constantinescu's term in power, when the influence of his office and his Cabinet had already started to wind down. By that time, however, the Atlantic Alliance had declined (in 1997) to extend an invitation for Romania to join NATO; the Government of Prime Minister Victor Ciorbea (1996-1998) did not regard NATO or EU accession as a major foreign policy priority, in the first place. It was mostly under Prime Ministers Radu Vasile (1998-2000) and Mugur Isarescu (April-November 2000) that the process of reform - more realistic steps toward downsizing, professionalization, improved defence funding and stronger civilian control over the military - was jumpstarted and began to be noticed in Brussels and Washington, DC. Generally, among the problems noted in relations between the Constantinescu 
regime and the armed forces, Larry L. Watts lists "the exclusion of Parliament [...] from decisions formally and constitutionally under its purview $[\ldots]$, the breakdown of relations between the Ministry of [National] Defense and the general staff [and] the vilification of the military by the Constantinescu administration as part of its attempt to undermine PDSR [...]."

Civil-military tensions resurfaced in late 2000, when a newly-founded National Officers' Association of Romania (ANMR) - with active, reserve and retired military personnel as members, including former Chief of the General Staff Gen. Mircea Chelaru - stated that its goal was to address problems negatively affecting the country's security and social life, e.g., corruption, antisocial and anti-national actions. Active military personnel are not legally allowed to engage in public political activity. Romania's political class reacted adversely to ANMR's goals and eventually managed to shut it down, yet its very existence (albeit short-lived) provided evidence of high levels of military adversity and mistrust vis-à-vis the country's legitimate representatives, as well as a constant need on the part of the armed forces to have a "say" in Romania's post-Communist era. The situation relating to the country' military establishment in the late 1990 s can further explain the emergence of ANMR: "[a]s a result of political intrusions, the effectiveness of the Romanian armed forces deteriorated, demoralization spread among officers and enlisted personnel, intra-service rivalries intensified, and the level of civil-military tension reached a new high."

s19 Ibid., 23, and interview with Dr. Larry Watts (Security and Defence Advisor, Presidential Administration of Romania), by the author, Bucharest, Romania, April 15, 2005.

${ }^{520}$ Ibid., 16. 
The year 2001 marked the return to power of PDSR (now called the Social Democratic Party or PSD) and President Ion Iliescu, but also a new impetus for defence reform. A more experienced government team on security and defence issues and a more stable political configuration insured better results on reform management. Also, as Marian Zulean points out, "[t] he dawn of the Prague NATO summit [December 2002, when the country was invited to join NATO] and Romania's expectations of becoming a member acted as an important stimulus for a focused effort in continuing the reform [process]." 521

A growing number of civilians were appointed to top positions in the Ministry of National Defence, including the three positions of Deputy Minister of National Defence: Parliamentary Relations; Supply and Procurement; and Defence Policy. As a means of ensuring compliance by armed forces with Government decisions - i.e., better civilian control over the military - MApN run a controversial campaign of conferring military ranks to civilians that would work in the military structure of this institution, such as the General Staff. It is worth noting that most of them had not had any prior experience and expertise normally required for those positions, a situation that aggravated civil-military relations. The Ministry's attempt to train civilian personnel (mostly through the country's National Defence College) were steps in the right direction, but insufficient in providing a significant number of civilian experts in the areas of security and defence.

Top military brass were irritated by an apparent lack of expertise and seriousness (bordering on abuse of position) on the part of Minister of National Defence Ioan Mircea Pascu. Shortly after taking over as head of MApN, he managed to become the target of

${ }^{521}$ Marian Zulean, Armata si societatea in tranzitie, 172. 
Romanian and international media for various inappropriate remarks made in relation to the media and his political opponents; it is also alleged that he used the military intelligence services for partisan political purposes and took personal trips in the Danube Delta using a rocket-enabled military frigate. This seemed to reflect badly on the military establishment as a whole and military leaders occasionally left their displeasure known publicly. These controversies occurred in a context in which, as a MApN official pointed out, the post-9/11 period "brought with it new dimensions to Romanian civil-military relations. New issues had to be more closely analyzed and discussed, such as terrorism as a security threat, integrated emergency preparedness and crisis management, and the role of the media." 522

The level of dissatisfaction with the civilian leadership of the Ministry transpired when Gen. Eugen Badalan replaced Gen. Mihai Popescu as Chief of the General Staff (the latter resigned to run as a candidate for the Senate of Romania in the elections of late 2004). "The Romanian Army," Gen. Badalan told newly-invested President Traian Basescu, " does not embrace control by certain civilians over certain military officers, but civilian control exercised through the national command authority. ${ }^{, 523}$ Gen. Badalan seemed to suggest, most analysts agree, that he would not accept orders easily from his direct superior, newly-appointed Minister of National Defence Teodor Atanasiu, only decisions formally approved by CSAT or the CSAT head, the President of Romania, who is also the Commander-in-chief of the armed forces. (De facto, the President has limited

\footnotetext{
${ }^{522}$ Interview with Dan Claudiu Degeratu (Director General, Department of Defence Policy, Ministry of National Defence of Romania), by the author, Bucharest, Romania, April 18, 2005.

$523 * * *$, "Alocutiuni cu prilejul investirii in functie a noului ministru al apararii nationale," http://www.mapn,ro, December 29, 2004 (accessed December 29, 2004).
} 
capacity to control the Government and to influence government decisions, including security and defence matters; Chiefs of the General Staff are traditionally controlled in Romania by the Ministers of National Defence).

This fourth political regime during Romania's post-Communist era marked renewed tensions between the country's civilian leadership and top military brass. They reached a level never experienced in recent history, the main players in the public civil-military confrontation being Chief of the General Staff Gen. Eugen Badalan, on the one hand, and Prime Minister Calin Popescu Tariceanu and Minister of National Defence Teodor Atanasiu, on the other. The conflict blocked progress on most MApN files, including 2005-2006 projects to streamline the organizational structure of the Ministry of National Defence and to overhaul the military intelligence services. Among others, Gen. Badalan opposed forcefully the proposal to appoint a civilian (rather than military) head to the General Directorate of Military Intelligence and questioned Mr. Atanasiu's ability to lead the Ministry, by not providing the military with sufficient financial resources.

The most significant clash occurred over Prime Minister Tariceanu's decision (supported by Mr. Atanasiu) to request, in early September 2006, the withdrawal of Romanian troops from operations in Iraq. Prime Minister Tariceanu had been mandated by his National Liberal Party (PNL) - one of the main political forces in the country's governing coalition, alongside the Democratic Party (PD), the Conservative Party (PC) and the Democratic Union of Hungarians in Romania (UDMR) - to propose to CSAT the military withdrawal, citing mostly financial concerns. Gen. Badalan opposed, once again, 
his political masters' position, noting: "[t]he Army is not an organization that is involved in partisan politics, but rather an institution that supports national interests. ${ }^{.524}$ In the end, CSAT, under President Basescu's direction, decided to keep Romanian forces in Iraq indefinitely; a few months later, both Gen. Badalan and Minister Atanasiu would be sacked, accused separately of abuse of position and suspicious dealings related to military procurement programs. Post-9/11 civil-military tensions, patterns of collaboration and their outcomes will be analyzed in-depth in the following sections of this chapter.

\section{V.3.b. Defence spending}

An analysis of post-Cold War patterns of interaction between Romania's civilian leaders and the country's top military brass reveals significant tensions over a large array of issues. Defence spending in particular became one of the most intense areas of contention: in a context in which the Romanian armed forces were reduced in size dramatically starting in the early to mid-1990s, civil-military conflicts over appropriate levels of funding for the military were unavoidable. Yet the post-9/11 period surprised even seasoned analysts in the virulence of the civil-military confrontation over the level of financial support for the armed forces - in the five years following the events of September 11, 2001, the conversation on this file degenerated into a public clash between top military officers and the country's civilian leaders.

The crux of the matter became the 2.38 percent of GDP agreed amongst the main political parties and, internationally, between Romania and the North Atlantic Treaty

\footnotetext{
${ }^{524}$ Anca Aldea, "Eugen Badalan: Armata nu face politica partizana," Jurnalul national, July 4, 2006.
} 
Organization as the most appropriate level of funding for the Romanian military. When governments repeatedly failed to meet this agreement - having to cater to different constituencies, both domestic and external (e.g., the EU) - the military made it clear it would make its voice heard. The ensuing confrontation, in 2005-2006, led to warnings from Minister of National Defence Teodor Atanasiu that he would force the resignation of Chief of the General Staff Gen. Eugen Badalan (finally, they both would be sacked on unrelated charges).

From 9/11 until the parliamentary and presidential elections of late 2004, civil-military disagreements over defence budgets - while significant - were mostly kept behind closed doors. Chief of the General Staff Gen. Mihail Popescu was largely unwilling to make public his case for increased military funding. Other than in parliamentary committee hearings, his musings about lack of sufficient equipment, difficulties in the institutional reform process and complications in international defence relations, as well as external military interventions, rarely touched directly on defence funding. It was just after his departure from active military life (in late 2004, when he was elected Senator in the Romanian Parliament) that he exposed his thoughts on the state of the armed forces.

While Gen. Popescu did not directly throw the responsibility into the Government's court - he became an elected politician on the governing party's (PDSR) electoral lists - many of his subordinates expressed their uneasiness with what they perceived as a crisis in the defence establishment. Chief of Land Forces Lt.-Gen. Sorin Ioan was one of several senior military officers who openly expressed their disappointment with the level of 
military funding, deeming it inappropriate vis-à-vis the institutional needs of the military and Romania's international military commitments. Speaking about the Land Forces, Lt.Gen. Ioan said his service did not receive enough funds even in order to complete the missions already under way: "Not according to our wishes, not according to the plans that we had. Not according to what we wanted and the strategic vision that we agreed upon." 525

With a significant number of Romanian soldiers deployed to various theaters of operations in Afghanistan and Iraq as part of the post-9/11 global war against terrorist and insurgent groups, lack of proper funding became easily noticeable. From insufficiently trained troops to lack of advanced body armour and personnel carriers to delays in institutional reform plans, issues related to procurement programs and levels of defence funding went steadily up on senior military leaders' priority agenda. Romanian President Traian Basescu argued that the situation had to be addressed urgently: "it is unacceptable," he said, for soldiers to wear body armour weighing over $15 \mathrm{~kg}$. at 40 degrees Celsius in the Afghan desert or to drive ARO military vehicles "that even a stone could get through." $\$ 26$

Having been given assurances by Ministry of National Defence officials that the Government had an ambitious procurement program and planed to replace fighter jets, infantry battle cars, tanks and anti-aircraft defence systems, President Basescu argued for increased efforts in addressing comprehensively all matters related to proper financial

\footnotetext{
${ }^{525}$ Interview with Lt.-Gen. Sorin Ioan, by Col. Francisco Stoica, "Vom valorifica experienta acumulata in teatre," Observatorul militar, nr. 42 (October 19-25, 2005).

526 ***, "Armata Romana este 'prost dotata," Gandacul de Colorado, no. 54 (July 2006).
} 
support for the military. "[E]ven if we had the most brilliant strategic and cooperation programs, if we neglected the equipment of the soldier, we would make a big mistake in our priorities," he said at a 2005 Ministry of National Defence press conference. ${ }^{527}$ A similar assessment was advanced by the country's parliamentary committees on security and defence issues, who repeatedly called on the Government to increase funding for the armed forces and to address their needs in a wide-ranging and all-inclusive manner. Mihai Stanisoara, Chairman of the Chamber of Deputies' defence committee said in September 2005 that "Romania should not go under the 2 percent of GDP threshold if it wants to preserve its international credibility;" he pleaded instead for 2.38 percent of GDP. $^{528}$

The most intense civil-military confrontation occurred in late 2005, between Minister of National Defence Atanasiu and Chief of the General Staff Gen. Badalan, over the draft defence budget for 2006. While Mr. Atanasiu stated that we has content with a military budget of 1.87 percent of GDP, Gen. Badalan warned that Romania would not be able to honour all its international commitments in Afghanistan, Iraq and other theatres of operations. The military, he argued, "cannot achieve its goals with the allocated budget for 2006 , which is 13 percent less than the required amounts;" he went on to say that various military agreements with the North Atlantic Treaty Organization would have to be renegotiated. ${ }^{529}$

\footnotetext{
${ }^{527}$ Anca Pol, "Gear Up: Basescu Tells Army," The Diplomat, April 2006.

${ }^{528}$ Radu Tudor, "10\% More for the Military Budget Next Year," Jurnalul national, October 1, 2005.

${ }^{529}$ Bogdan Costache, "Armata nu are bani de NATO," Adevarul, October 14, 2005.
} 
Gen. Badalan encouraged defence officials within MApN to harmonize budgetary levels with military plans at the beginning of every fiscal year or fiscal term, rather than force the military to review or modify abruptly missions and programs under way every time there is an unforeseen change in budgetary levels. In response to positions by the Chief of the General Staff on this file, Mr. Atanasiu stated that he would ask President Basescu to request Gen. Badalan's resignation. The conflict affected negatively the Ministry's activity, had an impact on the country's military cooperation programs and led to accusations on both sides of abuse of position, corruption and incompetence.

Since the Romanian armed forces underwent a process of downsizing starting in the early to mid-1990s, it would not be unusual for defence budgets to vary, i.e., to follow a similar downward trend. Not only in Eastern Europe, where countries engaged on a path of systemic transformation, but in most Western countries defence budgets were slashed significantly following the end of the Cold War. What the post-9/11 period seems to have added to this equation was a sense of purpose for the armed forces and renewed "munitions" in their negotiations with the Government over levels of defence funding. The more vigorous confrontation between the military and its civilian masters - in this case between the Chief of the General Staff and the Minister of National Defence, the latter being backed by the Prime Minister - provides evidence for the role played by the novel threat/strategic environment in shaping domestic patterns of civil-military relations. Given a combination of changing security priorities, new operational requirements and military pressures, the Government would steadily increase during the post-9/11 period the country's defence budgets, in both relative and absolute terms. As Minister of 
National Defence Sorin Frunzaverde would explain in early 2007, the new yearly defence budgets of over 2 billion Euros (about 3.2 billion Canadian dollars) would support "the procurement programs that we have initiated, equipment renewal and career advancement programs, but for just $\mathbf{8 8 , 0 0 0}$ people that are currently employed by the Forces. To put this in perspective, we had defence budgets of 600 million US dollars in the mid-1990s for $180-200,000$ positions. ${ }^{, 530}$

The Romanian armed forces perceived their involvement in military operations overseas and, in general, its more active role at home and abroad as an opportunity to advance its institutional agenda. The post-9/11 threat environment not only influenced political and military developments in countries around the globe, Romania included; it was also used as a platform for institutional repositioning amongst state organizations. In a country in which the armed forced have traditionally held a key role in shaping the debate on security and defence matters, Romanian military officials used their reinforced role in the post-9/11 context to counterbalance the growing influence of civilian officials over these policy areas.

One of the negative side effects of this feud over defence budgets - and, at a broader level, over the direction of the armed forces in the new security environment and their role as one of the most important state institutions - was the virtual paralysis of MApN activity in 2005-2006 (until both key protagonists were sacked by the Prime Minister and the President). The Ministry's procurement plans were delayed for so many months in

\footnotetext{
530 Interview with Sorin Franzaverde (Minister of National Defence of Romania), "Vom respecta angajamentele asumate fata de aliati," Observatorul militar, no. 2/2007 (January 17-23), 2-3.
} 
2005 and, again, in 2006 that entire programs had to be cancelled. Gen. Badalan accused Minister Atanasiu of blocking this process through poor management, but also "in order to demonstrate that the budgetary level [requested by the military] was not needed." 531 Mr. Atanasiu denied the accusations, but asked CSAT in June 2006 to approve the withdrawal of Romanian troops from Iraq, invoking cost-related concerns. He stated that 11.8 percent of his ministry's annual budget is dedicated to the Iraqi mission - about USD 200 million, in absolute figures. "Withdrawing the troops would save us USD 90 million," he told CSAT, along with Prime Minister Tariceanu. ${ }^{532}$

Their argument was quickly condemned by Gen. Badalan, as well as President Basescu and other key political players, as lacking credibility. They were accused of playing partisan politics in order to score political points for their party (PNL), while putting the troops' lives in danger and damaging the country's image internationally. In late 2006, Minister of National Defence Teodor Atanasiu would change his position and agree with Chief of the General Staff Gen. Eugen Badalan over the necessity of a larger defence budget, corresponding to 2.38 percent of GDP. Their virulent conflict and its resolution provides evidence for a military institution that continues to be very influential in Romania's state system, very engaged in defending its interests and unwilling to place itself under full civilian control by the country's political establishment.

\footnotetext{
${ }^{531}$ Interview with Gen. Eugen Badalan, by Alina Grigore, "Relatia cu NATO, afectata de scandalurile din MApN," Prezent, June 19, 2007.

${ }^{532}$ Mihai Toader and Razvan Gheorghe, "Premierul jucator," ZIUA, June 30, 2006.
} 


\section{V.3.c. Government policies}

Not unlike the situation in other countries following the end of the Cold War, in Romania top civilian officials placed security and defence matters at the bottom of their overall policy agendas. Combined with a traditionally strong role of the armed forces in defining military "realities" and appropriate defence measures, Romanian officials struggled in their efforts to elaborate security and defence documents of a broad, encompassing nature. In many cases they de facto passed this responsibility to their military officials and research structures affiliated to the armed forces. Yet the events of September 11, 2001, reinforced in a dramatic manner the previous observation that security and defence challenges cannot be tacked separately from each other, but rather in an integrated manner.

This change of optics revealed the obsolescence of relying on the country's military to define or significantly shape the debate on security and defence issues. As clearly suggested by the National Security Strategy of 2001, the policy capacity in this area on the civilian side was considerably limited. The following years, top government officials indicated their desire to change this state of affairs, by strengthening policy groups within the Ministry of National Defence and trying to balance the civil-military involvement in this process. Nonetheless, both civilian and military officials generally used EU and NATO strategic papers as a template for corresponding Romanian documents, while the armed forces still played a crucial part in the Government's defence policy exercises. 
As George Maior, State Secretary for Defence Policy in the Ministry of National Defence, pointed out, "one of the problems emerging in the civil-military interaction revolved around the need for new defence planning concepts, which were supposed to broaden the civilian [officials'] level of expertise in areas previously considered a military responsibility, but holding important political significance." 533 These areas of expertise would encompass questions as diverse as the role and structure of the armed forces in the new international security environment; the type of measures needed to tackle new, emerging threats; external military cooperation and involvement in overseas military missions; membership in security alliances and bilateral and multilateral international relations.

During the 2001-2006 period, such questions were addressed primarily in the context of elaborating three key policy documents: the 2001 National Security Strategy of Romania, the 2004 White Paper on Security and National Defence and the 2006 National Security Strategy. In the context of civilian control over the armed forces, the most challenging tasks focused, among others, on "striking an appropriate balance between resources and political objectives [and] improving organizational management and public servants' level of expertise. ${ }^{.534}$ One of the most important institutions involved in these processes was the Department of Defence Policy and Planning within MApN, which was the driving force behind many research documents that had an impact on the final form of the

\footnotetext{
${ }^{533}$ George Maior, "Transformarea politicii de aparare a Romaniei: Trei teme de reflectie strategica," MApN Occasional Papers, no. 5 (III)/2004, 41.

${ }^{534}$ Ibid., 40.
} 
documents listed above - the Department drew heavily from work by uniformed officers, reflecting predominantly general concerns of the armed forces.

It is not unusual for Romanian military officials to express publicly views on the country's international relations, its strategic orientation, its security and defence priorities, and the direction of current or future security missions. This behaviour should not come as a surprise: even President Ion Iliescu noted in 2004 that "no matter how well equipped and trained an army would be, if the political side is not able to define in firm and clear terms $[\ldots]$ its internal and external objectives, it will end up defeated ... [The Romanian military's] stance is essential to ensure the existence and continuity of the national Romanian state. ${ }^{.535}$ While some analysts criticized Mr. Iliescu's remarks as endorsement of military intervention in the policy realm, most observers agreed with his criticism of civilian authorities, asking for improved civilian capacity in the areas of security and defence.

Among others, defence analysts Gelu Trandafir (of the Romania libera daily) ${ }^{536}$ and Ioana Lupea (Evenimentul zilei) ${ }^{537}$ engaged in sustained criticism of government performance on various files, particularly related to levels of expertise and interest in military affairs by Minister of National Defence Teodor Atanasiu and Prime Minister Calin Popescu Tariceanu. It was in this context that President Traian Basescu suggested that government officials often perceive security and defence matters, including key

\footnotetext{
535 ***, "Mesajul domnului Ion Iliescu, Presedintele Romaniei cu ocazia Zilei Armatei Romaniei," http://www.mapn.ro, October 25, 2004 (accessed October 25, 2004).

${ }^{536}$ Gelu Trandafir, "Atansiu, un ministru deposit de misiune," Romania libera, August 8, 2006.

${ }^{537}$ Ioana Lupea, "Moarte in Irak," Evenimentul zilei, April 28, 2006.
} 
international developments such as the US-led war in Iraq, as "too remote, both as [geographical] location and as [general] interest." ${ }^{538}$

The events of 9/11 did influence the content of the country's National Security Strategy (adopted in December 2001), yet the impact was rather superficial. Neither the military nor the civilian authorities had the necessary analysis capacity to grasp the implications of a novel international threat environment and to formulate solid policy documents. As Romanian scholar Dorina Maria Nastase pointed out, the 2001 NSS "represented an inertial extension of previous documents, with no absorption of the doctrinal consequences of the attacks of September 11 on the international strategic context. ${ }^{4539}$ The document was sent to Parliament for approval after a long delay, which triggered strong criticism from various quarters, Opposition politicians and various analysts accusing the government of incompetence.

This episode only reinforced the existing image of civilian authorities struggling to fulfill their responsibilities in the area of security and defence policy and provided the military with a strong impetus to continue its traditional involvement in this state activity. Military officials pushed through the idea of sending forces to faraway theatres in the newlydiscovered "war on terror" (largely supported by civilians as well), de facto altering the country's strategic orientation. Such empirical developments translated into significant changes in military doctrines, policy papers and other strategic documents. The moment the first Romanian troops touched down in Afghanistan and, later, in Iraq to fight

\footnotetext{
538 Ibid.

${ }^{539}$ Dorina Maria Nastase, "Strategia nationala de securitate: de la aparare teritoriala la securitate umana?," Revista 22, year XIV, no. 825 (December 27, 2005-January 2, 2006).
} 
alongside their NATO counterparts, the country's security and defence identity was radically altered - this new identity would be reflected in later policy documents, to which the military would also contribute substantially, both directly and indirectly.

The reinforced military assertiveness in the area of defence policy reached a peak around the opening stages of the 2003 US-led invasion of Iraq, with some military officers asking for deployment of Romanian troops to this new multinational mission - just as one of Romania's key Eastern European neighbours, Poland, did. Facing a complex political equation in the European Union - France and Germany being among the most vocal opponents of the war against Iraq - the country's political authorities were less convinced of the immediate need of sending Romanian soldiers to an already controversial theatre of operations (Romanian troops would eventually be deployed to Iraq, in July 2003). Joining a Chief of the General Staff meeting in late April 2003, Minister of National Defence Ioan Mircea Pascu criticized in strong terms the armed forces' involvement in political debates, which was "against military regulations." 540

Civilians would continue, however, to be highly dependent on military advice and forced to tolerate military officers expressing publicly views on political developments and policy options, as the Government was in the process of adopting a new White Paper on Security and National Defence. Prime Minister Adrian Nastase asked for a unified civilmilitary effort to jointly update the previous White Paper and the armed forces' military strategy, noting that "military power is no longer an issue of size, but of speed and

${ }^{540}$ Cristian Oprea, "Pascu, suparat ca militarii fac politica," Evenimentul zilei, April 26, 2003. 
mobility. The recent war in Iraq demonstrated this, once again." ${ }^{541}$ The new White Paper, released in 2004, provided further evidence for the need for a joint civil-military approach to shaping security and defence policy in post-9/11 Romania.

By 2006, when the country's National Security Strategy was revised, the capacity of civilian officials to master the intricacies of security and defence policy and to take control of this file, would not improve significantly. The 2006 NSS was produced under the supervision of President Traian Basescu and the Supreme Council of National Defence, with significant input from Chief of the General Staff Gen. Eugen Badalan and CGS-related structures. So little control had Prime Minister Calin Popescu Tariceanu and Minister of National Defence Teodor Atanasiu over the new text that the day the document was released Prime Minister Tariceanu complained publicly that his views were not fully taken into account. "I think the national security strategy should have reflected to a larger degree our efforts toward deeper integration into the European Union ... There are differences of opinion [between the Prime Minister's office and the military-backed Presidency]," Mr. Tariceanu said. ${ }^{542}$

In turn, Gen. Badalan would later accuse Mr. Atanasiu - and implicitly the Prime Minister - of an inability to understand security and defence matters and to represent adequately the armed forces, of incapacity to support military reform, of "childish behaviour" and a tendency to "always contribute to tense situations" - all these factors would mean, according to Gen. Badalan, "endangering the country's defence

\footnotetext{
${ }^{541}$ Ibid.

$542 * * *$, "CSAT a aprobat strategia de securitate nationala," BBC Romania, April 17, 2006.
} 
capacity." ${ }^{\text {543 }}$ Sabina Fati, a commentator with Revista 22, along with many other analysts, criticized the overall result, calling the 2006 NSS "an overly complicated and blurry document, asphyxiated by pointless words and concepts," which would suggest "either carelessness in the way the document was created or lack of professionalism on the part of its authors."

These post-9/11 developments provide evidence for weak policy capacity on the part of Romania's civilian authorities. In a country in which the armed forces have traditionally provided the Government with advice on strategic directions in the area of security and defence, this state of affairs contributed to maintaining the status quo. The end result was a set of documents that were rather poorly conceived and formulated, and continuing civil-military struggles for control over this realm. At the same time, as Dr. Marian Zulean pointed out, "the non-governmental sector's level of expertise on defence issues continued to be rather low, a situation that also characterized the parliamentary committees." ${ }^{\text {545 }}$ While government officials improved their position on this file vis-à-vis their military counterparts during the 2001-2006 period, they were not able to establish clear civilian control over the very important sphere of policy production.

\footnotetext{
${ }^{543}$ Interview with Gen. Eugen Badalan, by Alina Grigore.

${ }^{544}$ Sabina Fati, "Strategia de securitate nationala," Revista 22, year XV, no. 834 (March 1-7, 2006).

545 Interview with Dr. Marian Zulean (Security and Defence Advisor, Presidential Administration of Romania), by the author, Bucharest, Romania, April 15, 2005.
} 


\section{V.3.d. Defence transformation}

The need for a radical transformation of the Romanian armed forces was expressed by various interested actors immediately following the revolutionary events of December 1989. While the transformation process has been pursued at different paces during the post-Cold War era, it was after the terrorist incidents of September 11, 2001, that defence "transformation" gained a new, more imperative significance. This new sense of urgency came partly as a direct reaction to what was perceived to be a radically redefined international threat environment and partly as an attempt to use instrumentally the new security context to strengthen international relations with the United States and other European partners. The post-9/11 process of transformation did not differ fundamentally from developments in previous years, but the more intense process of planning and the faster pace of implementing it led to significant civil-military tensions.

They can be divided into three different, yet closely interconnected, categories: (i) differences of vision and conflicting interests, (ii) complications that emerged in the transformation process, and (iii) problems related to the energetic process of downsizing the Romanian armed forces. All these developments together contributed to a tense relationship between military leaders and their civilian counterparts and produced lessthan-optimal results. The current section of this chapter will assess the level of civilmilitary divergence in the area of defence transformation and will provide evidence for difficult civilian control over this file during the 2001-2006 period. 
Civilians were able to set the general terms of the defence transformation process, however the implementation of the master plan was heavily influenced by the military. One critical development was the 2005 attempt by Minister of National Defence Teodor Atanasiu, supported by Prime Minister Calin Popescu Tariceanu, to reorganize the National Defence Headquarters, an initiative that was blocked by Chief of the General Staff Gen. Eugen Badalan's team. Although MApN reorganization was part of the broader government agenda to transform the country's defence establishment, which both civilians and the military had agreed upon in principle, the two parties could not reach a common decision on the end result of that process. "I was not able to send the draft law to Parliament," Minister Atanasiu said, "because we don't share a common view on this file with the General Staff ... This failure makes me wonder how well we collaborate with the Romanian armed forces. ${ }^{\circ 56}$

Minister Atanasiu faced strong opposition vis-à-vis this project not only from Gen. Badalan, but also from a large number of uniformed military personnel working within the central structures of the Ministry of National Defence. Among its key initiatives, Mr. Atanasiu's draft law proposed "eliminating parallel structures and practices and improving civilian control over the armed forces;" some military positions within MApN were to be transferred to the military's operational structures, while some others were to be eliminated altogether. ${ }^{547}$ Out of a total of about 2,000 positions at the National Defence Headquarters, Mr. Atanasiu proposed maintaining 1,500-1,600; he argued that

\footnotetext{
${ }^{546}$ Radu Tudor, "Armata in razboi," ZIUA, June 21, 2005.

${ }^{547}$ Doru Dragomir, “Atanasiu: Adio, racani!,” ZIUA, October 24, 2005.
} 
the number of MApN positions should follow the similar trend of downsizing the armed forces themselves.

One of the most important proposals within Mr. Atanasiu's draft law concerned the appointment of a civilian head for the ministry's Military Intelligence Division (DGIA one of Romania's most important intelligence services) and combat-ready forces subordinated to this division. Chief of the General Staff Gen. Badalan opposed this idea openly, arguing that such a significant position - head of DGIA - should be kept out of the political appointment process. In making the case for his stance, Gen. Badalan held several press conferences and briefed Romanian President Traian Basescu; after losing his position as CGS, Gen. Badalan would also accuse Mr. Atanasiu of mismanagement and lack of understanding of the country's defence transformation needs. ${ }^{548}$

In the end, Mr. Atanasiu could not impose his position - President Basescu appointed Lt.Gen. Sergiu Madar as Head of the Military Intelligence Division. The episode served as a reminder of civilian leaders' limitations in imposing their viewpoints on matters deemed vital by their military counterparts; the transformation of Romania's defence establishment would only proceed when both civilian and military leaders agree on the principles of this process and a clearly defined implementation plan. Differences of vision and conflicting interests stalled the process whenever top military brass disagreed fundamentally with political decision makers' positions. In a 2007 interview, Minister of National Defence Sorin Frunzaverde pointed out that "a state of mistrust, of suspicion came to characterize the relations between [the civilian and the military structures in the

\footnotetext{
${ }^{548}$ Interview with Gen. Eugen Badalan, by Alina Grigore.
} 
process of defence transformation]. We are talking about a tense environment within the Ministry of [National] Defence, the exact opposite of what we should normally have in such an important organization."

Given the magnitude of Romania's defence transformation process, controversies related to the many procurement programs under way were also contributing factors to a state of civil-military apprehension. There were many procurement controversies during the 2001-2006 period, the largest occurring during the summer of 2006, when the Ministry of National Defence announced that Romania would investigate the circumstances and clauses of a contract signed by the previous Government with the United Kingdom's Royal Navy for the purchase of two used British frigates. Many officials considered the price tag of $£ 116 \mathrm{~m}$ for the two frigates suspiciously high; a Romanian navy chief, Adm. Victor Blidea said the military "could have bought surplus Dutch frigates three times more cheaply than the second-hand purchase of HMS London and HMS Coventry [later renamed by the Romanian navy Regele Ferdinand and Regina Maria] which needed extensive new equipment and were costly to maintain.. $\$ 50$

The contract had been signed in 2003 by former Prime Minister Adrian Nastase and several other members of his Cabinet. Minister of National Defence Teodor Atanasiu would suggest in 2006 that bribes in the range of several million British pounds might have been received by the company negotiating the bilateral deal (BAE Systems), but

\footnotetext{
${ }^{549}$ Interview with Sorin Frunzaverde, "Vom respecta angajamentele asumate fata de aliati."

${ }^{550}$ David Leight and Rob Evans, "Bribery inquiry may force $£ 7 \mathrm{~m}$ refund to Romania," The Guardian, June $15,2006$.
} 
also by high ranking civilian members of the Nastase Government. ${ }^{551}$ In a 2007 interview, former CGS Gen. Badalan said problems related to procurement programs were so pervasive that he would be able to produce documents showing the involvement of Minister Atanasiu himself in many suspicious agreements. ${ }^{552}$ All these developments, although not eroding the position of either civilian or military leaders in this equation, would further contribute to increased detachment and lack of understanding between the two sides.

Another key problem that emerged in the process of transformation of the Romanian armed forces related to downsizing the military and, as part of this process, reducing the number of senior military officers. It had been determined that, compared with most other NATO countries, Romania had one of the highest numbers of senior officers as a proportion of the total armed forces members. Although layoff campaigns were generally accompanied by customized employment insurance and other social protection programs, the military reacted largely negatively to civilian attempts to reduce its size. In the words of Minister Atanasiu, the plan was to have armed forces "with a smaller number of members $[\ldots]$, more flexible and more dynamic structures, and less duplication of responsibilities." He acknowledged that such a plan would be "opposed strongly by most people - everyone is very unhappy when you push ahead with such reforms. We'll have fewer positions and people fight to keep theirs. ${ }^{" 553}$

\footnotetext{
551 ***, "Conferinta de presa a ministrului apararii nationale," http://www.mapn.ro, June 1, 2006 (accessed July 1,2006 ).

${ }_{552}$ Interview with Gen. Eugen Badalan, by Claudiu Tarziu and Simona Popa, "Atanasiule, plecam impreuna," Cotidianul, September 17, 2007.

${ }_{553}$ Doru Dragomir, "Atanasiu: Adio, racani!"
} 
Military leaders expressed their deep displeasure with such initiatives and occasionally accused the Government of undermining one of the most trusted Romanian institutions (the Romanian Army and the Orthodox Church held steadily throughout the post-Cold War as Romania's most trusted organizations). When President Traian Basescu announced in early 2005 that he would no longer authorize the promotion of any military officer to the rank of general until 2007 (when the military would be scaled down to 90,000 members), many military leaders expressed their shock and discontentment with his position. Deputy Chief of the General Staff Maj.-Gen. Florian Pinta urged the President to reconsider his views. ${ }^{554}$ Out of 107 generals in early 2005 only 75 would remain in the Romanian military by 2007 , for a force of 75,000 military and 15,000 civilian members.

While the armed forces could not impose their views on this particular file, civil-military debates and occasional quarrels took place relating to the transformation of the armed forces at strategic, operational and tactical levels, and - as indicated above - in the area of defence procurement. The military was able to block civilian progress on several crucial initiatives meant to adapt the military institution to the requirements of a new international security context. Even when military and civilian leaders agreed in principle over the broad strategy for Romania's defence transformation, there was hardly agreement - as in the case of Canada and many other Western countries - over the precise details of that master plan: new organizational structures, novel policy approaches and military doctrines, and new equipment. While the Government seemed to retain control over the transformation agenda at a strategic level, the implementation of its plans

\footnotetext{
${ }^{554}$ Mihai Diac, "Conducerea Armatei spera ca numarul generalilor va creste," Adevarul, March 14, 2005.
} 
was hampered significantly by the military during the 2001-2006 period, especially during the terms of Mr. Atanasiu as Minister of National Defence and Gen. Badalan as CGS. In light of Romania's accession to the European Union in early 2007, “[c]oncepts in the Romanian Armed Forces' transformation strategy [...] had to be revisited," according to the country's new Chief of the General Staff, Adm. Gheorghe Marin. ${ }^{555}$

In a country in which the armed forces have traditionally been in charge of their own affairs, the proactive and forceful intervention of civilians in the security and defence realm was resented by many top military officers. Their sentiment was accentuated by the view on their part that government officials and other civilian authorities were not competent enough to make coherent decisions in this area; to the extent that decisions were made and plans implemented, e.g., in the area of defence procurement, civilians would often be accused of inefficiency, corruption and lack of transparency (as indicated above). As in the case of Canada, the analysis of civil-military interaction over defence transformation in post-9/11 Romania suggests a partial inability on the part of the country's civilian leaders to redesign the Romanian armed forces and to provide the military establishment with a clear vision for the future. The military would continue to hold a very significant role in shaping the debate on these subjects, some of its most evident concerns revolving around the defence transformation agenda and the country's priorities in relation to military issues.

\footnotetext{
${ }^{555}$ Interview with Adm. Gheorghe Marin (Chief of the General Staff of the Romanian Armed Forces), by Lt-.Col. Leonard Mocanu, "Armata trebuie privita ca un organism viu," Observatorul militar, no. 17/2007 (May 3-9), 2.
} 
V.3.e. Romania-United States defence relations

Romania-US relations had already been strong in late 1990s and early this decade, but the events of $9 / 11$ created a security and political environment stimulating their development. Romania's civilian leaders and top military officials alike promoted the growth of bilateral relations with the world's sole superpower. Stronger Romania-US defence relations were perceived as a renewed opportunity for the country's repositioning on the international stage and - domestically - improved prospects for higher defence funding. The most significant difference, however, between civilian and military leaders during the 2001-2006 period was noticeable at a broad level: while the military perceived the Romanian armed forces' relations with their American counterparts as a catalyst for institutional reconstruction and consolidation, and evidence of higher professionalism, Romanian politicians struggled at times with questions related to the extent of defence cooperation and the end-goal of its military interventions abroad.

These patterns are not only specific to Romania's post-9/11 civil-military relations; they can be identified in other Western countries as well, Canada included. Romanian politicians, by personal conviction or motivated by the desire to cater to different categories of voters, toned down some of their messages and occasionally engaged in political disagreements (even within the governing coalition) over the terms of RomaniaUS defence cooperation - particularly after the country was granted NATO membership status, in 2004. 
Many military leaders and some media commentators were surprised by what they perceived as wavering positions on the part of the Government on security and defence files involving Romania-US relations: "[w]hen European chancelleries used to open their doors for us with the security door chain in its lock position, the Americans lent us a hand. From Gen. [John] Shalikashvili, Chairman of the Joint Chiefs of Staff in the 1990s, and Secretary of State Madeleine Albright to Condoleeza Rice and George W. Bush, we have a consistent partnership [with the USA], based on strong strategic considerations. ${ }^{\not 566}$ Such commentators, including Chief of the General Staff Gen. Eugen Badalan, questioned occasionally government officials' stance on relations with the United States and military involvement in US-led operations abroad.

Three main issues help define civilian and military positions on Romania-US relations during the 2001-2006 period: the alleged presence on Romanian territory of secret CIA prisons (the most likely locations being the Kogalniceanu and Timisoara Romanian military airbases), the hosting of US military bases near the Black Sea and Prime Minister Calin Popescu Tariceanu's proposed withdrawal of Romanian troops from Iraq, in mid-2006. Other less significant topics will be touched upon as well, all together shedding light on civil-military dynamics in the context of Romania's post-9/11 defence links with the United States.

When Romania was accused, in late 2005, by Human Rights Watch of having hosted secret CIA detention centres in previous years, both civilian and military leaders denied

\footnotetext{
${ }^{556}$ Radu Tudor, "Tampenie si tradare," Jurnalul national, July 4, 2006.
} 
it. Romanian politicians declared the debate a non-issue, while military officers generally refrained from expressing any public views on this matter. Former Minister of National Defence Ioan Mircea Pascu said "planes carrying U.S. prisoners may have made stopovers in Romania," but he denied the existence of secret CIA (or US-run) prisons on Romanian territory. ${ }^{557}$ Both Prime Minister Calin Popescu Tariceanu and President Traian Basescu also vigorously rejected the human rights group's accusations. Despite this position, Mr. Pascu added that it was entirely possible and even likely that planes carrying al-Qaeda suspects made stopovers on the Kogalniceanu and Timisoara military airports. He said part of these airbases were off limits to Romanian authorities and asked: "What's it all about? What seems to be the problem? [Terror suspects] did not reach Guantanamo on foot. ${ }^{, 558}$ Most notable in this debate was the virtual absence of military voices, although the two locations identified by Human Rights Watch and other organizations as possible prison locations were military bases.

The national and international controversy surrounding these accusations did not have a negative impact on civil-military relations in Romania; on the contrary, it seemed to have provided a common ground for the two sides - both valued significantly Romania-US defence relations and were reluctant to provide evidence for any possible wrongdoing. A Council of Europe investigation, led by Swiss Senator Dick Marty, offered no proof for the existence of CIA prisons on Romanian territory, but put the Timisoara airbase in a

\footnotetext{
557 Alison Mutler, "Former Romanian minister says part of base used by U.S. troops off-limits to Romanians," Associated Press, November 21, 2005.

558 Jacqueline Prager and Calin Cosmaciuc, "Romania, halta CIA," Evenimentul zilei, November 20, 2005.
} 
"detainee transfer/drop-off point" category, together with a Polish airport and eight other locations outside Europe and North America. ${ }^{559}$

Similar patterns of civil-military interaction can be detected in relation to the project of establishing several US military bases in Romania, along the Black Sea coast (the Kogalniceanu airfield as the largest base and three other military sites for smaller, rotational bases: Smardan, Babadag and Cincu). Both civilian and military leaders embraced the idea of closer political and defence relations with the United States, which the presence of US bases on Romanian territory would only strengthen. From late 2004, when the idea of such bases became an explicit item on the two countries' bilateral agenda, until mid-2007, when the Romanian Parliament approved the presence of US troops on Romanian territory (with overwhelming support from parliamentarians), the debates revolved around administrative details only.

Minister of National Defence Teodor Atanasiu said in late 2005 that the last important items of the bilateral agreement to be negotiated were, at the time, the financial aspects of building and maintaining the necessary infrastructure, and issues related to ownership rights. ${ }^{560}$ The only publicly known incident in the area of civil-military relations occurred when Mr. Atanasiu removed Brig.-Gen. Valeriu Nicut from his position as head of the military's strategic planning department after the top officer had told reporters, in late May 2005, that Romania and the United States had indeed reached an agreement to set up US bases near the Black Sea. Minister of National Defence Teodor Atanasiu removed

\footnotetext{
559 Jan Sliva, "Secret CIA Flights Stopped in Two Countries," Associated Press, July 6, 2006.

${ }^{560}$ Doru Dragomir, “Atanasiu: Adio, racani!," ZIUA, October 24, 2005.
} 
Gen. Nicut from his post "for making unauthorized statements to the media" at a time when the exact terms of the agreement were not yet finalized. ${ }^{561}$

An item that created a deep rift, however, between the military and their political masters was the presence of Romanian troops in the controversial US-led intervention in Iraq. While the armed forces firmly supported this mission, the Government proposed in mid2006 the withdrawal of Romanian military personnel from this Middle Eastern country. The deployment of Romanian troops to Afghanistan and Iraq in 2002-2003 was meant to address global security concerns in what was generally perceived to be a new international threat environment, but also - and perhaps more importantly - to strengthen relations with the United States and reassure other Western partners of Romania's stance in the war against terrorist and insurgent forces. Over the years, however, the threat-based rationale behind the presence of Romanian forces in two far-away countries started to be reassessed in Romanian political circles. A request by Prime Minister Calin Popescu Tariceanu and Minister of National Defence Teodor Atanasiu to the Supreme Council of National Defence, regarding the withdrawal of Romanian troops from Iraq, was met with strong opposition from Chief of the General Staff Gen. Eugen Badalan (backed by President Traian Basescu).

Gen. Badalan, along with a number of other key military and political figures, pointed to the potential damage such an initiative might cause to Romania-US relations. "The death and serious injury of Romanian soldiers is becoming a concern," said Mr. Tariceanu, citing financial considerations as well; in response, Gen. Badalan and President Basescu

561 ***, "Romania Removes Top General from Key Post," Associated Press, May 28, 2005. 
argued that the withdrawal would undermine Romania's strategic partnership with the United States. "I have the impression that not all the relevant parties, whether in Romania or beyond, were consulted," the US Ambassador to Romania, Nicholas F. Taubman, said in response to this incident. ${ }^{562}$ In the end, the episode caused significantly fewer problems in Romania-US relations (as Romanian troops would continue their activity in Iraq) than in Romanian civil-military relations: the Government's credibility was badly damaged, while civilian control over the military became open to discussion.

The Government's credibility took another plunge when Minister of National Defence Teodor Atanasiu seemed to handle poorly an incident involving a CD-ROM with sensitive (secret and top-secret) information involving military operations in Iraq and Afghanistan, including US forces' activities, which was leaked to the Romania media. Mr. Atanasiu first claimed the information on the CD-ROM was harmless, only to change his mind a few days later and call for an investigation into the incident. Almost unanimously, Romanian media accused the gaffe-prone minister of another blunder and questioned his ability to run the ministry and to maintain working defence relations with the USA and Romania's other partners; some even asked for his resignation. ${ }^{563}$ Combined with his performance on other files, the episode weakened his position vis-àvis his military counterparts, at a time when the civilian side struggled to improve its capacity for control of the country's armed forces.

\footnotetext{
562 Alison Mutler, "Romania May Withdraw Its Troops from Iraq," Associated Press, June 29, 2006. 563 ***, "Micile secrete ale lui... Teodor Atanasiu," http://www.hotnews.ro, September 8, 2006 (accessed September 8, 2006).
} 
While the civil-military interaction on the various aspects of Romania-US defence relations does not suggest overall military control over this file, the various points of contention and a general inability of civilians to clearly make a case for their position and drive change provide evidence for a mixed picture. The civilian principals lost in some of their key "battles" with the armed forces leadership, which provides further evidence against strong civilian oversight over defence issues in post-9/11 Romania.

\section{V.3.f. Military responses}

The deployment of Romanian troops to Afghanistan and Iraq in the early stages of the two US-led interventions (2002-2003) constituted a radical change in the country's recent history of military deployments - not only were Romanian soldiers sent abroad in a predominantly combat role, it was the first time they participated in such missions on other continents and in such large numbers. While the deployments did not generate much debate initially, 2005 marked the beginning of a more serious discussion of Romania's military role in the two theatres of operations, the reasoning behind sending troops to Afghanistan and Iraq and the end-goal of those operations. However, it was not until 2006 that clashes between the country's civilian and military leaders would come to the forefront of the conversation on military deployments overseas.

As in other Western countries, the terms of the debate were different when talking about Afghanistan than talking about Iraq: there was a much higher level of civil-military agreement over the legitimacy of sending Romanian troops to Afghanistan in the war 
against international terrorism and the chance of achieving the proposed military and political objectives than was the case with the Iraq mission. While the armed forces' leadership supported both assignments, as they seemed to promote organizational growth and prestige for the defence establishment, a significant number of the country's civilian leaders - led by the Cabinet - distanced themselves from the mission in Iraq, by proposing a phased troop withdrawal from this Middle Eastern country. The current section will assess the civil-military interaction vis-à-vis the two deployments and draw partial conclusions on civilian control over the armed forces during the 2001-2006 period.

The Afghanistan mission was generally seen in Romania as a justifiable reaction to the attacks of September 11, 2001, against the United States; there was a clear sense among Romanian officials that a response was necessary and that Romania should join the fight against al-Qaeda and the Taliban regime that had hosted and supported the perpetrators of 9/11. Even several years after Romanian troops had first landed on Afghan soil, this view did not change much; in fact, throughout the 2001-2006 periods, both military and civilian leaders agreed with the general idea of having Romanian troops on the ground, even in the more dangerous areas of southern Afghanistan. As the first major military deployment in generations, the Afghan mission was widely embraced by the armed forces as a chance for institutional renewal and better repositioning amongst state organizations (after decades of neglect and radical budget cuts). 
On the political side, the mission was seen as a reasonable reaction to a brutal act and as an unexpected chance to strengthen relations with Romania's Western allies (especially the United States), particularly in the context of its membership in the North Atlantic Treaty Organization. The Afghan deployment thus represented a good opportunity to promote more harmonious civil-military relations, with both the armed forces and civilian authorities on the same side of an important debate. At the same time, however, it provided the military with further incentives to advance more forcefully its agenda relating to better defence funding, more influence in shaping the country's security and defence policies, greater control over the defence transformation agenda and a stronger voice on international partnerships, particularly Romania-US defence relations.

Although the deployment of Romanian troops to Afghanistan generally contributed to improved relations between military and civilian leaders, it also acted as a catalyst for disagreements on different, yet related issues. In the area of defence spending, senior military officials used the participation of Romanian soldiers in missions in Afghanistan, Iraq and other theatres of operations as a firm argument for higher defence budgets. When a more serious conflict over defence spending broke in 2005-2006 between Minister Atanasiu and Gen. Eugen Badalan, the Afghan and Iraqi missions were invoked frequently by the armed forces as the main driving force behind their position. In the area of defence policy as well, the country's military involvement in two major areas of operations offered further incentives for the armed forces to stay involved actively in all key debates relating to defence and security issues. 
The Afghan mission in particular, as a longer and more clearly defined military intervention, helped decision makers define their basic stance on Romania's involvement in post-9/11 security and defence operations (and fine-tune the country's stance on tactical and operational aspects); all these conversations strengthened military leaders' position vis-à-vis their civilian counterparts, rather than weakening it. A new sense of urgency in the realm of defence transformation, post-9/11, was also brought forward by the need to adapt the defence establishment to the requirements of participating in two major international interventions overseas. Participating in military operations in Afghanistan and Iraq also brought changes in Romania-US defence relations and occasionally led to civil-military clashes - as investigated in the previous section of this chapter.

The Iraq intervention was approached differently from the Afghan mission from its early stages - particularly by the Government and the political parties that formed Romania's governing coalition. There was largely a sense of disconnect between the broader goals of addressing the new global threats (chiefly among them, international terrorism and the proliferation of weapons of mass destruction) and the US-led intervention, whose main objective seemed to be toppling the ruling regime in Baghdad. The Romanian Government felt compelled to join the Iraq mission, as a candidate country (at the time) to NATO, a US-led defence alliance; the military supported it unreservedly, as it provided further opportunities for the forces to train and engage in military operations alongside respected Western establishments. Another factor contributing to the initial positive decision to deploy Romanian troops to Iraq (on the civilian side) was the widely 
accepted view that toppling authoritarian regimes and spreading democracy around the world - with presumed positive spin-off effects - was a responsibility, indeed an obligation, for Western nations. Romanians had long waited during their own authoritarian regime, prior to 1989 , for a Western intervention to overthrow the Ceausescu regime.

Nonetheless, when the initial excitement over the rapid fall of the Hussein regime in Baghdad ran low, given the continuing sectarian violence in Iraq, combined with US findings over lack of evidence for a weapons of mass destruction program, questions arouse within political circles over the rationale behind the high price to be paid in this theatre of operations. While the emerging debate on the Iraq mission was seen by many as a healthy approach to a complicated issue, the military reacted largely negatively. In early 2005 , shortly after retiring from active military duty, former Chief of the General Staff Gen. Mihail Popescu expressed what many uniformed personnel thought: that questioning the mission equals questioning the work done by military men and women in Iraq. Moreover, presenting the Romanian military, in the political conversation, as a possible "force of occupation" is "not only an act that confuses the Romanian troops, but also dishonours them." 564

The most significant hurdle in the interaction between civilian and military leaders in relation to the Iraq war arose in mid-2006, when Prime Minister Calin Popescu Tariceanu and Minister of National Defence Teodor Atanasiu proposed the withdrawal of Romanian

\footnotetext{
${ }^{564}$ Mihail Popescu, "Trupele armatei romana nu pot fi considerate trupe de ocupatie in Irak," http://www.senat.ro, March 21, 2005 (accessed June 10, 2007).
} 
troops from Iraq, in direct opposition to Chief of the General Staff Gen. Eugen Badalan's stance. Although the final decision, by the Supreme Council of National Defence, was to keep the troops on the ground, the clash shook seriously the system of civilian control over the armed forces, by revealing its flaws. President Traian Basescu, who mediated between the two sides (although siding more with the military) expressed his dissatisfaction with the state of civil-military relations, arguing for increased efforts to resolve their key differences.

While reminding the parties involved that the principle of civilian control over the armed forces should be respected at all times, he accused the Government of poor understanding of Romania's strategic interests and of weak policy analysis capacity, by indicating that "the proposed withdrawal [of Romanian troops from Iraq] lacks adequate analysis and it only creates the impression of incoherent guiding principles in Romania's foreign and defence policy." 565 Other observers noted as well the poor level of preparedness and weak arguments proposed by the Prime Minister and the Minister of National Defence in trying to advance their position; the fact that their proposal came immediately after the death of a Romanian soldier in Iraq was also widely presented in the media as on opportunistic move. Parliament's involvement in this crisis was limited to holding hearings in defence committees with some of the key actors involved, particularly Mr. Atanasiu.

Overall, the analysis of civilian and military positions in relation to Romania's two most important military missions during the period under study (2001-2006) reveals patterns of

${ }^{565}$ Mihai Toader, "Dovada puciului," ZIUA, July 1, 2006. 
interaction that do not support the idea of strong civilian control over the armed forces. The Afghan mission was conducive to less antagonistic relations, given a larger portion of shared viewpoints among civilian and military leaders; it did not lead to conflict, mainly because the military agreed with civilians on most key points. On the Iraq file, different perspectives on the mission and different institutional interests pitted the military against their civilian masters, in a show of force that humiliated the country's civilian leaders and further strengthened the armed forces' influence on security and defence matters.

\section{V.4. Assessment of findings}

The chapter has provided evidence for the idea of strained civil-military relations in Canada and Romania over the period covered by this study (September 11, 2001September 11, 2006). At the very least, civilian leaders were unable to impose their will in a number of situations in which their perspectives differed from those of their military counterparts. Although distinct cases, Canada and Romania showed similar patterns of civil-military relations: an inability of the civilian authorities to fully control the conversation on security and defence issues, and in many cases to provide leadership on military-related matters, combined with a propensity on the part of armed forces to have a larger "say" on topics related to this realm. The Romanian case study reveals, nonetheless, slightly stronger disagreements between civilian and military officials than in the Canadian context. A related problem in Canada over the timeframe covered by this study concerned the civilian principals who - by deliberate choice or by default - 
occasionally abdicated their responsibilities in the military arena, particularly in the areas of defence policy and strategic decision making.

On all five key topics identified as relevant to the interaction between civilian and military leaders - (i) defence spending, (ii) government policies, (iii) defence transformation, (iv) relations with the United States and (v) military responses in the new security environment - civilian leaders had to strike compromises with their military colleagues. Although in some of the cases the military "lost" its battles with the civilian authorities, in other instances civilian officials were unable to hold their positions when the armed forces expressed dissimilar views. The following review will summarize the resolution of key civil-military disagreements in the two countries, in the context of the five issue areas listed above. The next chapter of this thesis will synthesize these findings and will attempt to incorporate them into the larger theoretical framework.

\section{V.4.a. Defence spending}

\section{- Canada}

On the issue of defence spending, the Canadian military was able to put over the period covered by this study significant pressure on the Government. Chiefs of the Defence Staff, particularly Gen. Rick Hillier, used official meetings and public fora to advance the armed forces' interests for higher defence spending levels. Encouraged by a wave of media attention and in the context of the Afghan war, Canadian Forces leaders (and the larger defence community) gave the Government little leeway on this file. Although 
decisions on defence spending were made in the end by the civilian principals, the armed forces were able to influence considerably the terms of the debate on appropriate funding for the country's military.

- Romania

In the case of Romania, disagreements over defence spending degenerated into fullfledged civil-military conflict. Romania was, on the one hand, in the process of downsizing its armed forces and reducing their overall budgetary levels and, on the other hand, attempting to react to a changed threat environment and impress its Western partners by sending troops to Afghanistan and Iraq. Deficiencies in providing the forces with needed equipment and in ensuring sufficient funding for operational and tactical effectiveness pitted military leaders squarely against their civilian counterparts. The Government would finally gave in to strong military pressure, which supports the idea of civilian inability to control this file.

\section{V.4.b. Government policies}

- Canada

A customary lack of interest on the part of recent governments on military issues, coupled with increased pressures generated by a new threat environment and by Canada's involvement in military operations in Afghanistan, provided further incentives for the military to engage in policy work. While this tendency was kept under control during Gen. Henault's tenure as Chief of the Defence Staff, Gen. Hillier changed course and 
became the driving force behind the country's process of redefining its security and defence agenda. Significant international events prompted policy positions by Gen. Hillier; the Afghan mission was dubbed "Hillier's War." Overall, the military managed to drive Canada's defence policy process to a considerable extent.

\section{- Romania}

A traditionally important role of the armed forces in defining Romania's defence priorities and a lack of advanced expertise on the part of civilian authorities on defence matters placed the armed forces in the driver's seat in the policy-making process. At the same time, both civilian and military authorities used NATO and other Western policy papers as sources of inspiration for national documents and strategies. However, many observers noted many more deficiencies in the realm of defence policy on the part of civilian, rather than military authorities. It was also the military who strongly supported the deployment of Romanian troops to both Afghanistan and Iraq, and their continued presence there; especially in the case of Iraq, the armed forces led the mission, militarily and politically.

\section{V.4.c. Defence transformation}

- Canada

The process of transformation of the Canadian Forces was influenced decisively at strategic level by senior military staff, at operational and tactical levels by both military and civilian leaders, and in the area of defence procurement to a significant extent by the 
armed forces. When conflicts broke out over proposals for the transformation of the Canadian Forces and the defence establishment, civilian authorities were partly unable to impose their viewpoints. Disagreements occurred over defence procurement projects, which had implications for the larger strategies relating to the country's armed forces. Gen. Hillier's influence seemed to slip away slightly under the Conservatives, yet the Government was still unable to fully impose its positions, unwilling to antagonize the military and its supporters.

- Romania

The Romanian armed forces underwent a large-scale process of transformation following the end of the Cold War; post-9/11, this process grew in intensity and its pace increased, and led to tensions between civilian and military leaders. There were differences of vision and conflicting interests; also, complications emerged in the context of various transformation projects and difficulties occurred in the process of downsizing the forces. Civilians were generally able to set the general terms of the process, while the military seemed to have the last word on the ways of implementing the overall transformation strategy. On this file, especially related to organizational downsizing, the armed forces were unable to oppose civilian decisions; however, they were still able to block many other crucial initiatives. 


\section{V.4.d. Relations with the United States}

\section{- Canada}

While both civilian and military authorities actively promoted strong Canada-United States defence relations, in most cases when disagreements occurred, civilian leaders were able to impose their preferences over their military counterparts. As a general rule, top military brass supported unreservedly stronger relations with the US military establishment, while Canadian politicians were more cautions in their positions. The most significant civil-military clash occurred over proposed Canadian participation in the US National Missile Defense project, which Prime Ministers Chrétien, Martin and Harper did not endorse. The Canadian Forces continued to promote actively other bilateral projects, yet the Cabinet was firmly in control of the NMD file, despite military disappointment with the civilian principals' decisions.

- Romania

Both civilian and military leaders actively promoted strong Romania-US defence relations during the period covered by this study. Both camps perceived improved relations with the world's superpower as a catalyst for further professionalization of the defence establishment and improved positioning of Romania on the global stage. However, Romanian politicians struggled at times with the implications of supporting unreserved collaboration on common projects. While debates relating to alleged CIA detention sites and US military bases at the Black Sea did not cause civil-military 
tensions, the Iraq deployment led to a deep rift. These developments do not suggest military control over this file, yet they are indicative of mixed civilian success.

\section{V.4.e. Military responses}

- Canada

While Canada did not deploy troops to Iraq in the aftermath of the US-led invasion of this Middle Eastern country, Prime Minister Jean Chrétien "compensated" by sending a large contingent to Afghanistan - against the advice of his military advisors. This marked the beginning of a turbulent period in Canadian civil-military relations, with the military - in a reversal of their original position - eventually pushing for more active engagement in Afghanistan. It was Chief of the Defence Staff Gen. Hillier that promoted the deployment of troops to the dangerous area of Kandahar and an increased focus on combat operations. Prime Minister Harper reinstated civilian control over this file, yet the military continued to exercise considerable influence over the terms defining the mission.

- Romania

For the first few years of Romania's military interventions in Afghanistan and Iraq, civilian and military leaders seemed to be on the same page - both supported the deployments in every respect. The 2005-2006 period marked the beginning of differences of opinion, with a growing number of civilian officials, including Prime Minister Calin Popescu Tariceanu and Defence Minister Teodor Atanasiu asking for the withdrawal of Romanian troops from Iraq and a review of the Afghan mission. Their position was 
forcefully opposed by Chief of the General Staff Gen. Eugen Badalan who, backed by President Traian Basescu, managed to keep the troops on the ground. These developments provide evidence against the idea of strong civilian control of the military. 


\section{Conclusions}

This thesis has investigated patterns of civil-military relations in Western countries over a period of five years (September 11, 2001-September 11, 2006). It has argued that there is a direct correlation between specific threat environments (the dependent variables) and models of civil-military interaction (the dependent variables). To link analytically the overall threat configuration during the given timeframe to civil-military relations, the thesis identified five intermediate variables: (i) defence spending, (ii) government policies, (iii) defence transformation, (iv) relations with the United States of America and (v) military responses to the new threat environment. Employing two case studies, Canada and Romania, the thesis tested and provided evidence against the validity of one of the major theoretical constructs in the field of civil-military relations, Michael C. Desch's framework on the relationship between threat configurations and forms of civilian oversight of the armed forces.

The thesis argued that in the first five years of the post-9/11 era countries such as Canada and Romania faced an indeterminate threat environment that did not fit closely any of Desch's categories. During this five-year timeframe, the empirical data gathered from the two national contexts suggested that there were frequent instances of serious disagreement between civilian and military leaders. While the overall principle of civilian 
control over the armed forces was not openly called into question, the study revealed discordance between the two sides on many of the issue areas investigated in this thesis. The empirical findings and theoretical implications tend to falsify Desch's theory or render it irrelevant in most cases potentially applicable to contemporary Western polities. The current conclusions provide a brief assessment of the empirical data and of Desch's framework against the background of other theoretical constructs in the field and offers a set of research suggestions meant to advance future work in the field of civil-military relations.

The empirical findings suggest that given the nature of the threat environment during the 2001-2006 period, with the US-led global "war on terror," civil-military relations in Western countries were characterized by a closely knitted blend of internal and external threats that were virtually indistinguishable from each other, coupled with patterns of tense interaction between civilian and military elites. Both case studies employed in the context of this thesis, Canada and Romania, revealed similar findings, despite obvious differences in the history, political culture, geo-strategic context and foreign relations of the two countries.

The thesis laid out the foundations for the study by proposing an analytical strategy and a methodological framework appropriate for the given topic and by indicating the place of the study in the theoretical civil-military relations literature. As part of the main arguments, it specified independent variables (the overall threat environment), intermediate/intervening variables (defence-related systemic or national factors) and 
dependent variables (patterns of civil-military relations). It thus set the background for the analysis of the nature of threats and their intensity, of changes in the area of military affairs and of the resolution of disagreements between top civilian officials and the military leadership in the two national contexts - Canada and Romania, taken separately.

The research design and specific strategies devised to pursue the study of civil-military relations in this analytical context were carefully crafted to be compatible with Michael C. Desch's theoretical framework, whose propositions this thesis has tested. Using a different ontological reality, different epistemological approaches and different research tools to test Desch's theory would have defeated the purpose of this exercise. Yet one of the surprising findings of this study was precisely that using Desch's overall approach to the subject matter is unproductive in the security environment encountered following the events of September 11, 2001. Two of the most important factors hampering such an effort from the perspective of Desch's theoretical stance is that internal and external threats cannot be easily differentiated, and that the proposed unambiguous separation of civilian and military spheres of competence and responsibility is increasingly difficult to identify empirically and justify in normative terms. The analysis was based on the use of qualitative methods and employed a combination of multiple research strategies, including comparative examination and case studies. As indicated previously, the choice of these research tools improved the prospect of gaining better empirical understanding of the complex area of civil-military relations and testing and formulating theoretical statements for this field. 
The thesis explored the new threat environment following the terrorist incidents of September 11, 2001, and Western countries' changing security priorities in the new strategic context. It investigated the impact of $9 / 11$ on the post-Cold War world order and the proposed reasons for the near-consensus behind recognizing the fight against terrorist and insurgent forces as the new security priority of this era. It also explored these topics in the two national contexts - Canada and Romania - by shedding light on these two countries' perspectives on the new security environment, the governments' security concerns and some of their key responses to the new strategic realities, especially in the area of national defence.

These latter aspects were examined in detail, as they provide evidence for the extent to which Western governments recognized $9 / 11$ as the dawn of a new era in international relations and for the way security and defence matters have since been tackled. After making a few terminological remarks on the concepts of "terrorism," "weapons of mass destruction" and "state failure," and providing a series of general considerations on the security context, the thesis offered an assessment of the post-9/11 threat environment.

The empirical evidence and analyses by experts and officials provided in the context of Canada and Romania largely support the idea of post-Cold War and particularly post9/11 threats as having both an internal and external dimension, at the same time; they can be conceptualized in the end as a new breed of threats, corresponding to a novel global security environment. Statements by Canadian government organizations and independent analysts contribute to making a case for such a threat assessment. It is the 
nature of these new security challenges, crossing national boundaries, that questions the appropriateness of Michael C. Desch's distinction between internal and external threats. An argument can be made that, from a national security perspective, some of the external security challenges can be viewed as threats because of the new danger they pose to Western homelands. Moreover, there was concern that external operations in the "war on terror" might result in terrorists seeking to strike back not at deployed forces but against more vulnerable national territories and populations; this provides evidence of a further blending of the external and internal security environments.

From Chiefs of the Defence Staff to Prime Ministers and Ministers of National Defence to academics, the post-9/11 period was perceived in Canada as a changed security environment, requiring novel policies, mechanisms and capabilities to address the dangers of this new era, the majority of them originating beyond the country's borders. The brief analysis of policy-related, strategic and institutional changes in the context of Canada was used in the thesis to the extent that they offered convincing evidence for the existence of a qualitatively different post-9/11 threat configuration, along the lines described above.

Similar developments and similar conclusions were reached in the context of the second case study used in this thesis, Romania. Despite its greatly different geo-political positioning, recent historical trajectory and distinct domestic institutional organization from Canada's, Romania has approached the post-9/11 era in similar terms. As in the case of Canada, Romanian officials and nongovernmental experts tended to agree on the 
inter-twining nature of the new threats (terrorism, coupled with WMD proliferation and failed and failing states) and the need to address the country's security vulnerabilities. Both the Canadian and the Romanian governments also used instrumentally the changed global security environment, to maintain their place or better position themselves on the international scene, particularly in relation to the hegemon of the international system, the United States.

The thesis looked at the transformation of military affairs during the 2001-2006 period, by focusing on five key areas that link the need to reform the defence establishments based on the requirements of a new security environment to the dependent variable, civilmilitary relations. These five areas are a consequence of the new security milieu and also contributing factors to changing patterns of interaction between the civilian and the military leadership in a national context. They were analyzed from a general perspective, while also providing an in-depth analysis in the context of the two case studies, Canada and Romania.

As intermediate variables, these issue areas were approached in the context of this thesis primarily as distinct settings for the national civil-military interaction. They were not only essential to the transformation of the defence scene in Western countries during the 2001-2006 period, but they also constituted the backdrop for topics of contention and/or concordance between the military and the civilian leadership, at least in the two national contexts studied at length here, Canada and Romania. 
The analysis of post-9/11 military-related developments in Canada also helped uncover an unmistakable departure from the status quo of earlier years, with clear consequences for the state of civil-military relations. A similar analysis of these factors in the context of the second case study, Romania, reveals comparable findings. An examination of general debates in the areas of security and defence, of various policy instruments and measures initiated during this five-year period, and of military responses overseas indicated the multifaceted character of this exercise. Romanian civilian and military elites engaged forcefully in this debate, in the process reshaping the nature of the interaction between the country's armed forces and its civilian authorities.

By looking at the interaction between civilian and military leaders in the context of each of the five issue areas in the two national contexts, Canada and Romania (taken separately), the thesis provided a composite picture of the state of civil-military relations for the first five years of what has become known as the "post-9/11 era." In a nutshell, it investigated if civil-military relations in Canada and Romania over the period covered by this study (September 11, 2001-September 11, 2006) were "good" - using Michael C. Desch's terminology and methodology - and provided evidence for the idea of a strained interaction between top civilian officials and the military establishment.

By looking at the five issue areas that "pitted military preferences against those of civilians" in the two polities, the study supported the case for military preferences prevailing some of the time, i.e., civilian control of the military that, according to Desch, 
is "not firm." "566 This appraisal refers particularly to those areas over which a Western country's civilian authorities have control traditionally, e.g., defence policy. Civilian leaders were often forced to strike compromises with an obstinate military establishment or to engage in public disputes with their military counterparts. The post-9/11 security environment is conducive to apprehensive relations between the actors involved in tackling the new threats, as best strategies for success are open to discussion and the role of defence organizations in addressing the changing security realities is constantly renegotiated.

Given the fact that Michael C. Desch defines "good," "mixed," "poor" and "worst" civilmilitary relations based on the extent to which civilian officials are able to impose their perspectives over their military counterparts and in light of these research findings, it may be useful to (re)visit a few other theoretical positions on civilian control over the armed forces. Underlying Desch's thesis is an assumption of the need for a clearly delineated distinction between the areas of competence and responsibility of civilian and military authorities (although Desch himself does not define exactly these areas in his book). The discrepancy, however, between academic prescriptions and empirical findings raises the question of the validity of the idea of a rigid "division of labour," which has inspired scholarly debate - particularly in a Huntingtonian tradition - for decades.

Has it ever been the case that military and civilian leaders conform strictly to what is a priori defined in the theoretical literature as their area of competence and refrain from "venturing" into their counterparts' territory? Do empirical analyses indicate that, as a ${ }^{566}$ Michael C. Desch, Civilian Control of the Military, 5. 
rule, such an approach leads to an improved interaction between a state's civilian authorities and its armed forces? In normative terms, should scholars promote this "solution" unreservedly? Has the threat environment brought forward by the events of September 11, 2001, changed anything in this approach and, if so, what exactly? This thesis does not claim to provide answers to these questions (they fall beyond its scope), yet in light of the research findings it deems it appropriate to raise the issue of the appropriateness of a rigid line of demarcation between the responsibilities of senior civilian and military officials.

As Frank Hoffman noted, "[w]e need to reject an outdated normal theory of civil-military relations to a more historically grounded model that accounts for the overlapping and reciprocal interrelationship of ends, ways and means that leads to strategic success. ${ }^{.567}$ It is, in broad terms, the same position as expressed by Douglas L. Bland, who is nevertheless much more specific, emphasizing the need for civilian control over the armed forces, managed and maintained through regimes of shared responsibility between the two principal actors. For Bland, these reciprocal interrelationships mean that "some responsibilities for control may merge," but "they are not fused" - "[s]hared responsibility does not mean equal responsibility. ${ }^{.568}$ Although proposing his theory of shared responsibility in the pre-9/11 context, the approach seems to be equally applicable to the post-9/11 security context. It is broad enough to allow for close interaction between civilian officials and the military in a variety of partnership arrangements and specific enough to facilitate the formulation of researchable hypotheses.

\footnotetext{
${ }^{567}$ Frank Hoffman, "Dereliction of Duty Redux?"

${ }^{568}$ Douglas L. Bland, "A Unified Theory of Civil-Military Relations," 9.
} 
Approaching consensus in decision-making processes as a "critical component of defence administration, ${ }^{, 569}$ Bland's theory is still inspired by separate areas of competence for a state's civilian leaders and their military counterparts (although in a rather minimal sense). While it allows for a wider range of overlapping responsibilities, Bland's theory raises the "unanswered questions [of] how and where the balance [between civilian and military leaders' responsibilities] is struck and how it is managed over time." ${ }^{.570}$ This civil-military balance could vary from period to period and from country to country; more elaborate research on this area, in future studies, could shed further light on this central issue in the civil-military relations literature.

New work building on Bland's framework presents the potential of illuminating patterns of civil-military relations not only in Western countries during the post-9/11 era (the scope of this thesis), but in other contexts as well. In particular, new paradigms revolving around the issue of civil-military distribution of responsibilities could address some of the flaws identified in Michael C. Desch's theory, notably the over-reliance on separate civilian and military spheres. This latter structural imperfection led Desch to draw artificial conclusions on types of civilian control over the military in various threat configurations. In addition, a framework in which one party's win is the other party's loss focuses in large measure on antagonistic patterns of civil-military relations and restricts (largely a priori) research on cohabitation/collaboration between civilian and military leaders on topics of mutual concern.

\footnotetext{
${ }^{569}$ Douglas Bland, "Protecting the Military from Civilian Control," 112.

${ }^{570}$ Douglas L. Bland, "A Unified Theory of Civil-Military Relations," 12.
} 
A more flexible approach may yield better results in describing and possibly predicting empirical developments, and in allowing observers to make sense in a more productive manner of the subject matter under investigation, the civil-military interaction. While - as Bland and other scholars argue, on a normative basis - strategic decisions on security and defence issues should rest ultimately with civilian authorities, new frameworks should reflect the more integrated civil-military patterns of interaction in the security and defence area that seem to characterize the post-9/11 era. Moreover, attempts such as Desch' theoretical proposal to elucidate patterns of civil-military relations by employing a basic $2 \times 2$ matrix, although appealing, may be unproductive - as Richard Kohn pointed out, "[c]ivilian control is not a fact, but a process, that varies over time and is very much situational, that is, dependent on the issues and the personalities, civilian and military, involved at any given point." ${ }^{571}$ Accounting for such factors may require more complex or more flexible frameworks than the one proposed by Michael C. Desch in Civilian Control of the Military.

Other critical positions on Desch's theory, expressed by scholars in recent years, look at a different aspect of his model, questioning the appropriateness of a rigid distinction between the external and the internal dimensions of threats in the post-9/11 security environment. Rod Lyon, for instance, argued that "the age of terror takes us outside the neat categories of the Desch model." Predicting contentious civil-military relations in the post-9/11 era, Lyon pointed out - against Desch - that internal and external threats

\footnotetext{
${ }^{571}$ Richard Kohn, "Out of control: the crisis in civil-military relations," 14.
} 
"might well be the same." 572 The evidence provided in this thesis supports the idea of largely indistinguishable boundaries between external and domestic threats in a Western context. From a Canadian and Romanian perspective, it was the external environment that constituted the primary source of security threats to these countries and, by extension, to Western polities, but they presented the potential to materialize on domestic soil. Further work building on Desch' theory may also take a more in-depth look at an aspect insufficiently explored by the author of Civilian Control of the Military: the causation (not just correlation) between structural conditions, e.g., threat environments, and patterns of civil-military relations.

Future research based on alternative premises relating to threat configurations presents the potential to further advance work in this field, yet such an approach falls beyond the scope of this thesis. The same thing could be said about alternative frameworks that would abandon the normative stance of the need, ultimately, for civilian control over the military. Rebecca L. Schiff's "theory of concordance" could serve as a source of inspiration for new theories approaching the subject matter from this angle - potentially applicable to both Western and non-Western cases. ${ }^{573}$ New security contexts and reactions triggered among civilian institutions and armed forces could also encourage scholars to revisit the concept of "military professionalism," particularly in light of an increased focus on inter-agency coordination, e.g., civil-military cooperation (CIMIC) at the theatre level.

\footnotetext{
${ }^{572}$ Ron Lyon, "Civil-Military Relations in an Age of Terror."

${ }^{573}$ Rebecca L. Schiff, "Civil-Military Relations Reconsidered."
} 
Overall, while trying to invalidate some of Desch's theoretical propositions, the author of this thesis agrees with many of his fundamental assumptions. They correspond to what could constitute part of a future research agenda for the field of civil-military relations. Issues relating to the under-theorization of this academic field have to do largely with lack of agreement over basic principles to guide scholarly explorations. Reaching relative consensus over the definition of "civil-military relations" should be a very first step in this direction. This subject area even competes over this title with a related, but significantly different field - what is known as "civil-military cooperation" or the interaction between the armed forces and various civilian agencies, particularly in a postconflict reconstruction setting. (In the context of this thesis, the focus is on the interaction of civilian and military elites: senior civilian officials and top military leaders). The following five research suggestions could form the basis for fruitful future investigation in this field.

(i) Civil-military relations as a field of academic scholarship should focus - as Michael C. Desch and others approach it - on the process of civilian control over the armed forces. It is what differentiates, in the end, this academic area from related fields, at least in a political science tradition.

(ii) Related to this aspect, part of a comprehensive research agenda could be the analysis of the civil-military "division of labour" in providing security and defence services, although in a less strict sense than the approach used by Desch in his study. Douglas L. 
Bland's theoretical framework comes closer to such an approach, while being based on the idea of civilian control over the military.

(iii) A third important aspect to investigate (or at least to account for its impact) is the influence of external and domestic factors on national patterns of civil-military relations. Michael C. Desch has advanced considerably research along these lines, by proposing one of the most recognizable frameworks linking changes in civil-military interaction to external and internal security developments. A focus on the impact of institutions and practices (internal and external) could offer an alternative avenue to account for such a process.

(iv) Future theories of civil-military relations should further differentiate between Western and non-Western contexts (or between democratic and non-democratic polities that act as a backdrop for civil-military dealings). While Rebecca L. Schiff and other scholars touched on this issue in formulating their theories or assessing alternative frameworks, there is no in-depth discussion in the field on what makes Western and nonWestern (democratic and non-democratic) patterns of civil-military relations different from each other. The schools focusing on Western and non-Western (the latter called, at times, "Third World") cases and theories of civil-military relations do not seem to communicate significantly with one another.

(v) Finally, scholars should pay closer attention to the interaction of civilian and military leaders in wartime as opposed to peacetime. Eliot A. Cohen focuses in depth on wartime 
civil-military relations, but neither he nor other scholars integrate comprehensively the impact of periods of war and peace on civil-military affairs. In the post-Cold War era and particularly in the post-9/11 period, differentiating between the two conditions may prove to be a challenging task; some observers may even make a case for the obsoleteness of such an approach.

It is this author's intention to build on the findings in this thesis and attempt to integrate the above-mentioned approaches to civil-military relations. Proposing such a comprehensive theoretical framework here is beyond the scope of this thesis. What this dissertation strove, instead, to accomplish was to examine one of the most important theories in the field of civil-military relations - a theory that integrates many of the elements recognized as important in previous paragraphs - and review its strengths and weaknesses.

Desch's framework is unsatisfactory in elucidating the relationship between threat environments and patterns of civil-military relations, and in predicting empirical developments - at least in the post-9/11 context. Michael C. Desch's theory, however, serves as a useful source of inspiration and a practical basis for further research in this area. Significant scholarly effort and cooperative work is required, however, to improve the state of theory in this field and to better integrate the study of civil-military relations within the larger discipline of political science. 


\section{Bibliography}

\section{Books}

Alberts, David S., and Richard E. Hayes. Power to the Edge: Command and Control in the Information Age. Washington, DC: US Department of Defense, 2004.

Babiuc, Victor. "Reform of the Romanian Armed Forces: Modernization and Interoperability." In Romania and Euro-Atlantic Integration, ed. Kurt W. Treptow and Mihail E. Ionescu. Portland: The Center for Romanian Studies, 1999.

Chanda, Nayan, and Strobe Talbott (ed.). The Age of Terror: America and the World after September 11. New York: Basic Books, 2001.

Chehabi, H. E., and Alfred Stepan. Politics, Society, and Democracy. Comparative Studies. San Francisco: Westview Press, 1995.

Clawson, Patrick (ed.). Strategic Assessment 1996: Elements of U.S. Power. Washington, DC: Institute for National Strategic Studies, 1996.

Cohen, Eliot A. Supreme Command: Soldiers, Statesmen and Leadership in Wartime. New York: The Free Press, 2002.

Crenshaw, Martha, and Maryann Cusimano Love. "Networked Terror." In Beyond Sovereignty: Issues for a Global Agenda, ed. Maryann K. Cusimano. Belmont, CA: Thomson Wadsworth, 2003.

Cusimano, Maryann K. (ed.). Beyond Sovereignty: Issues for a Global Agenda. Belmont, CA: Thomson Wadsworth, 2003.

Degeratu, Claudiu. "Civil-Military Relations in Romania: Objectives and Priorities." In Civil-Military Relations in South-East Europe, ed. Plamen Pantev. Vienna: Institut für Internationale Friedenssicherung, 2001.

Desch, Michael C. “Threat Environments and Military Missions.” In Civil-Military Relations and Democracy, ed. Larry Diamond and Marc F. Plattner. Baltimore and London: The Johns Hopkins University Press, 1996.

Desch, Michael C. Civilian Control of the Military: The Changing Security Environment. Baltimore and London: The Johns Hopkins University Press, 1999. 
Diaconescu, Gheorghe, et al. Democratic Control over the Army in Romania. Bucharest: Editura Enciclopedica, 1996.

Diamond, Larry, and Marc F. Plattner (ed.). Civil-Military Relations and Democracy. Baltimore and London: The Johns Hopkins University Press, 1996.

Duncan, W. Raymond, et al. World Politics in the 21st Century. New York: Longman, 2002.

Feaver, Peter D. Guarding the Guardians: Civilian Control of Nuclear Weapons in the United States. Ithaca: Cornell University Press, 1992.

Feaver, Peter D. Armed Servants: Agency, Oversight, and Civil-Military Relations. Cambridge, MA: Harvard University Press, 2003.

Felberbauer, Ernst M., et al. Transforming National Armed Forces in South East Europe: From the Social to the Military Challenge. Vienna: National Defence Academy and Bureau for Security Policy, 2005.

Finer, S. E. The Man on Horseback: The Role of the Military in Politics. London: Pall Mall Press, 1971.

Gaddis, John Lewis. "And Now This: Lessons from the Old Era for the New One." In The Age of Terror: America and the World after September 11, ed. Nayan Chanda and Strobe Talbott. New York: Basic Books, 2001.

Goldstein, Joshua S. International Relations. New York: Longman, 2002.

Goldstein, Joshua S. International Relations. New York: Pearson Longman, 2004.

Gongora, Thierry, and Harald von Riekhoff (ed.). Toward a Revolution in Military Affairs? Defense and Security at the Dawn of the Twenty-First Century. Westport, Connecticut and London: Greenwood Press, 2000.

Granatstein, J. L. Whose War Is It? How Canada Can Survive in the Post-9/11 World. Toronto: Harper Collins Publishers Ltd., 2007.

Gross Stein, Janice, and Eugene Lang. Unexpected War: Canada in Kandahar. Toronto: Viking Canada, 2007.

Hamilton, Dwight (ed.). Inside Canadian Intelligence: Exposing the New Realities of Espionage and International Terrorism. Toronto: Dundurn Press Ltd., 2007.

Hanson, Jim, and Susan McNish (ed.). The Military in Modern Democratic Society. Toronto: Canadian Institute of Strategic Studies, 1996. 
Holmes, M. Studiu privind controlul parlamentar asupre Ministerului apararii nationale al Romaniei si controlul democratic asupra fortelor armate. Bucharest: Ministerul Apararii Nationale, 1997.

Homer-Dixon, Thomas. The Upside of Down: Catastrophe, Creativity and the Renewal of Civilization. Toronto: Knopf Canada, 2006.

Horn, Col. Bernd (ed.). The Canadian Way of War: Serving the National Interest. Toronto: Dundurn Press, 2006.

Huntington, Samuel P. The Soldier and the State: The Theory and Politics of CivilMilitary Relations. Cambridge, MA: Harvard University Press, 1967.

Janowitz, Morris. The Professional Soldier: A Social and Political Portrait. Glencoe, IL: The Free Press, 1960.

Janowitz, Morris. The Military in the Political Development of New Nations: An Essay in Comparative Analysis. Chicago and London: The University of Chicago Press, 1964.

Kuhn, Thomas S. The Structure of Scientific Revolutions. Chicago: The University of Chicago Press, 1970.

Lee, Rensselaer W., and James L. Ford. "Nuclear Smuggling." In Beyond Sovereignty, ed. Maryann K. Cusimano. Belmont, CA: Thomson Wadsworth, 2003.

Lombardi, Ben. "The International Security Environment." In Strategic Assessment 2003, ed. S. E. Speed. Ottawa: Department of National Defence, 2003.

McKitrick, Jeffrey, et al. "The Revolution in Military Affairs." In Battlefield of the Future: $21^{\text {st }}$ Century Warfare Issues, ed. Barry Schneider and Laurence E. Grinter. Maxwell Air Force Base, AL: Air University Press, 1995.

Michta, Andrew A. The Soldier-Citizen: The Politics of the Polish Army after Communism. New York: St. Martin's Press, 1997.

Millett, Allan R. The American Political System and Civilian Control of the Military: A Historical Perspective. Columbus: Ohio State University Press, 1979.

Mychajlyszyn, Natalie L., and Harald von Riekhoff (ed.). The Evolution of Civil-Military Relations in East-Central Europe and the Former Soviet Union. Westport: Praeger, 2004.

Naroll, R., and R. Cohen (ed.). Handbook of Method in Cultural Anthropology. Garden City, NY: Natural History Press, 1970.

Naroll, Raoul. "Galton's Problem." In Handbook of Method in Cultural Anthropology, ed. R. Naroll and R. Cohen. Garden City, NY: Natural History Press, 1970. 
Nelson, Daniel N. (ed.). Romania after Tyranny. Boulder, CO: Westwiew Press, 1992.

Off, Carol. The Ghosts of Medak Pocket: The Story of Canada's Secret War. Toronto: Random House Canada, 2004.

Pantev, Plamen (ed.). Civil-Military Relations in South-East Europe. Vienna: Institut für Internationale Friedenssicherung, 2001.

Pascu, Ioan Mircea. "Parliamentary Control over the Military." In Romania and EuroAtlantic Integration, ed. Kurt W. Treptow and Mihai Ionescu. Oxford: The Center for Romanian Studies, 1999.

Pelletiere, Stephen C. (ed.). Terrorism: National Security Policy and the Home Front. Carlisle Barracks, PA: Strategic Studies Institute, 1995.

Phares, Walid. The War of Ideas: Jihadism against Democracy. New York: Palgrave Macmillan, 2007.

Pigott, Peter. Canada in Afghanistan: The War So Far. Toronto: Dundurn Press, 2007.

Popa, Dragos Constantin. "Civilian Control over the Military in Bulgaria and Romania (1989-2004)." In Transforming National Armed Forces in South East Europe: From the Social to the Military Challenge, ed. Ernst M. Felberbauer et al. Vienna: National Defence Academy and Bureau for Security Policy, 2005.

Popper, Karl. The Logic of Scientific Discovery. London: Routledge, 2002.

Popper, Karl. The Open Society and Its Enemies. Vol. II. The High Tide of Prophecy. Hegel and Marx. London: Routledge \& Kegan Paul Ltd., 1957.

Robertson, Scot. "Years of Innocence and Drift: The Canadian Way of War in the PostCold War Era." In The Canadian Way of War: Serving the National Interest, ed. Col. Bernd Horn. Toronto: Dundurn Press, 2006.

Rotberg, Robert I. (ed.). When States Fail: Causes and Consequences. Princeton: Princeton University Press, 2003.

Rotberg, Robert I. "The Failure and Collapse of Nation-States: Breakdown, Prevention, and Repair." When States Fail: Causes and Consequences, ed. Robert I. Rotberg. Princeton: Princeton University Press, 2003.

Sagan, Scott D., and Kenneth N. Waltz (ed.). The Spread of Nuclear Weapons: A Debate Renewed. New York: W. W. Norton \& Company, 2003. 
Sagan, Scott D. "Sagan Responds to Waltz." In The Spread of Nuclear Weapons: A Debate Renewed, ed. Scott D. Sagan and Kenneth N. Waltz. New York: W. W. Norton \& Company, 2003.

Schneider, Barry, and Laurence E. Grinter (ed.). Battlefield of the Future: $21^{\text {st }}$ Century Warfare Issues. Maxwell Air Force Base, AL: Air University Press, 1995.

Shain, Yossi. “Minimum Claims, Maximum Gains: The Advantages of Juan Linz's Definition of Democracy." In Politics, Society, and Democracy. Comparative Studies, ed. H.E. Chehabi and Alfred Stepan. San Francisco: Westview Press, 1995.

Sloan, Elinor C. Security and Defence in the Terrorist Era. Montreal: McGill-Queen's University Press, 2005.

Sloan, Stephen. "Terrorism: How Vulnerable is the United States?." In Terrorism: National Security Policy and the Home Front, ed. Stephen C. Pelletiere. Carlisle Barracks, PA: Strategic Studies Institute, 1995.

Speed, S. E. (ed.). Strategic Assessment 2003. Ottawa: Department of National Defence, 2003.

Stanley, Jay (ed.). Essays on the Garrison State. London: Transaction Publishers, 1997.

Stanley, Jay. Introduction to Essays on the Garrison State, ed. Jay Stanley. London: Transaction Publishers, 1997.

Thériault, Gen. (ret'd) Gerard. "Democratic Civil-Military Relations: A Canadian View." In The Military in Modern Democratic Society, ed. Jim Hanson and Susan McNish. Toronto: Canadian Institute of Strategic Studies, 1996.

Treptow, Kurt W., and Mihail E. Ionescu. Romania and Euro-Atlantic Integration. Oxford: The Center for Romanian Studies, 1999.

von Clausewitz, Carl. On War. New York: G. P. Putnam's Sons, 1967.

von Riekhoff, Harald. Introduction to The Evolution of Civil-Military Relations in EastCentral Europe and the Former Soviet Union, ed. Natalie L. Mychajlyszyn and Harald von Riekhoff. Westport: Praeger, 2004.

Waltz, Kenneth N. Theory of International Politics. Reading, MA: Addison-Wesley, 1979.

Watts, Larry L. "The Romanian Army in the December Revolution and Beyond." In Romania after Tyranny, ed. Daniel N. Nelson. Boulder, CO: Westwiew Press, 1992. 
Wilkinson, Paul. Terrorism and the Liberal State. New York: New York University Press, 1986.

Zulean, Marian. Armata si societatea in tranzitie. Bucharest: Tritonic, 2003.

\section{Journal articles}

Allison, Graham. "Is nuclear terrorism a threat to Canada's national security?" International Journal, vol. 60, issue 3 (Summer 2005).

Avis, Capt. (N) Peter, and Iain Grant. "Canadian Maritime Security and the Culture of Prevention." Canadian Military Journal, vol. 5, no. 4 (Winter 2004-2005).

Avis, Capt. (N) Peter. "Seductive Hegemon: Why NATO Is Still Important to Canada." Canadian Military Journal, vol. 5, no. 1 (Spring 2004).

Barkun, Michael. "Defending against the apocalypse: The limits of homeland security." Policy Options, September 2002.

Bland, Douglas L. "A Unified Theory of Civil-Military Relations." Armed Forces \& Society, vol. 26, no. 1 (Fall 1999).

Bland, Douglas L. "Finding National Defence Policy in 2004." Canadian Military Journal, vol. 4, no. 4 (Winter 2003-2004).

Bland, Douglas. "Hillier and the new generation of generals: The CDS, the policy and the troops." Policy Options, March 2008.

Bland, Douglas L. "Parliament's Duty to Defend Canada." Canadian Military Journal, vol. 1, no. 4 (Winter 2000-2001).

Bland, Douglas L. "Patterns in Liberal Civil-Military Relations." Armed Forces \& Society, vol. 27, no. 4 (Summer 2001).

Bland, Douglas. "Protecting the Military from Civilian Control: A Neglected Dimension of Civil-Military Relations." Democratic and Civil Control over Military Forces - Case Studies and Perspectives, no. 3 (1995).

Bland, Douglas. "Who decides what? Civil-military relations in Canada and the United States." Canadian-American Public Policy, issue 41 (February 2000).

Bland, Douglas L., and Roy Rempel. "A Vigilant Parliament: Building Competence for Effective Parliamentary Oversight of National Defence and the Canadian Armed Forces," Policy Matters, vol. 5, no. 1 (February 2004). 
Burk, James. "Theories of Democratic Civil-Military Relations." Armed Forces \& Society, vol. 29, no. 1 (Fall 2002).

Caparini, Marina. "The Challenge of Establishing Democratic Civilian Control Over the Armed Forces of Central and Eastern Europe." Canadian Defence Quarterly, vol. 2, no. 2 (Winter 1997).

Carment, David. "Effective Defence Policy for Responding to Failed and Failing States." Canadian Defence \& Foreign Affairs Institute's Research Paper Series.

http://www.carleton.ca/cifp/docs/EffectiveDefencePolicyFailedStates.pdf, June 2005 (accessed July 2, 2006).

Cha, Victor D. "Globalization and the Study of International Security." Journal of Peace Research, vol. 37, no. 3 (2000).

Cioflina, Lt.-Gen. Dumitru. "Restructuring and Modernizing the Romanian Armed Forces." NATO Review, vol. 42, no. 4 (August 1994).

Coscodaru, Col. Ion. "Terorismul: Implicatii asupra actiunilor militare." Gandirea militara romaneasca, no. 6/2001.

Cottey, Andrew, et al. "The Second Generation Problematic: Rethinking Democracy and Civil-Military Relations." Armed Forces \& Society, vol. 29, no. 1 (Fall 2002).

Davis, $2^{\text {nd }}$ Lt. Jessica M. "From Kosovo to Afghanistan: Canada and Information Operations." Canadian Military Journal, vol. 6, no. 3 (Autumn 2005).

Desch, Michael C. "Soldiers, States, and Structures: The End of the Cold War and Weakening U.S. Civilian Control." Armed Forces \& Society, vol. 24, no. 3 (Spring 1998).

Donnelly, Chris. "Defence Transformation in the New Democracies." NATO Review, no. 6 (November 1996).

Donnelly, Chris. "Reform realities." NATO Review, vol. 49, no. 3 (Autumn 2001).

Dutkiewicz, Piotr, and Sergei Plekhanov. "The Politics of 'Mimicry': The Case of Eastern Europe." In The Soldier and the State in the Post Cold-War Era, ed. Albert Legault and Joel Sokolsky. A special issue of the Queen's Quarterly (2002).

Epstein, Rachel A. "NATO Enlargement and the Spread of Democracy: Evidence and Expectations." Security Studies, vol. 14, no. 1 (January-March 2005).

Evraire, Lt.-Gen. (ret'd) Richard J. "Security in a New Era: Rethinking Canadian Defence and Foreign Policy." On Track, vol. 7, no. 3 (October 9, 2002). 
Fati, Sabina. "Strategia de securitate nationala." Revista 22, year XV, no. 834 (March 17, 2006).

Feaver, Peter D. "Civil-Military Relations." Annual Review of Political Science, vol. 2, no. 1 (1999).

Feaver, Peter D. "Crisis as Shirking: An Agency Theory Explanation of the Souring of American Civil-Military Relations." Armed Forces \& Society, vol. 24, no. 3 (Spring 1998).

Feaver, Peter D. "The Civil-Military Problematique: Huntington, Janowitz, and the Question of Civilian Control." Armed Forces \& Society, vol. 23, no. 2 (Winter 1996).

Fergusson, James. "Shall We Dance? The Missile Defence Decision, NORAD Renewal, and the Future of Canada-US Defence Relations." Canadian Military Journal, vol. 6, no. 2 (Summer 2005).

Fergusson, James. "Wanted? A Canadian Defence Policy." Canadian Defence and Foreign Affairs Institute Newsletter, Summer 2006.

Fitzsimmons, Scott. Book review of The Ghosts of Medak Pocket: The Story of Canada's Secret War, by Carol Off. Toronto: Random House Canada, 2004. In Canadian Military Journal, vol. 6, no. 1 (Spring 2005).

Floca, Gen. Mihail. "Europa sub teroare." Observatorul militar, no. 11 (March 17-23, 2004).

Fowlow, Fred R. "Have You Heard?" On Track, vol. 9, no. 3 (Autumn 2004).

Garrett, Laurie. "The Nightmare of Bioterrorism." Foreign Affairs, vol. 80, no. 1 (January/February 2001).

Graves, Frank. "U.S. and Canadian Outlooks on Threats: Coherence or Contradiction?" One Issue, Two Voices (Woodrow Wilson International Center for Scholars), issue 4 (October 2005).

Gibson, Christopher P., and Don M. Snider. "Civil-Military Relations and the Potential to Influence: A Look at the National Security Decision-Making Process." Armed Forces \& Society, vol. 25, no. 2 (Winter 1999).

Gosselin, Brig.-Gen. Daniel, and Dr. Craig Stone. "From Minister Hellyer to General Hillier." Canadian Military Journal, vol. 6, no. 4 (Winter 2005-2006).

Gourevitch, Peter. "The Second Image Reversed: The International Sources of Domestic Politics." International Organization, vol. 32, no. 4 (Autumn 1978). 
Graham, Ross. "Civil Control of the Canadian Forces: National Direction and National Command." Canadian Military Journal, vol. 3, no. 1 (Spring 2002).

Hillmer, Norman. "Reflections on the unequal border." International Journal, vol. 60, issue 2 (Spring 2005).

Hillmer, Norman. "The secret life of Canadian foreign policy." Policy Options, February 2005.

Hilton, Col. D. Craig. "Shaping Commitment: Resolving Canada's Strategy Gap in Afghanistan and Beyond." Strategic Studies Institute, the U.S. Army War College, http://www.StrategicStudiesInstitute.army.mil, July 2007 (accessed July 29, 2007).

Homer-Dixon, Thomas. "The Rise of Complex Terrorism." Foreign Policy, issue 128 (January/February 2002).

Horn, Col. Bernd. "When Cultures Collide: The Conventional Military/SOF Chasm." Canadian Military Journal, vol. 5, no. 3 (Autumn 2004).

Huebert, Rob. "New and formidable challenges require new and fresh thinking." On Track, vol. 7, no. 4 (December 20, 2002).

Ignatieff, Michael. "Ethics and the New War." Canadian Military Journal, vol. 2, no. 4 (Winter 2001-2002).

Jockel, Joseph T., and Joel J. Sokolsky. "Dandurand revisited: rethinking Canada's defence policy in an unstable world," in International Journal, vol. 48 (Spring 1993).

Jockel, Joseph T., and Joel J. Sokolsky. "Renewing NORAD - Now if not forever." Policy Options, July-August 2006.

Kemp, Kenneth W., and Charles Hudlin. "Civil Supremacy over the Military: Its Nature and Limits." Armed Forces \& Society, vol. 19, no. 1 (Fall 1992).

Kohn, Richard. "Out of control: The crisis in civil-military relations." The National Interest, no. 35 (Spring 1994).

Krasner, Stephen D., and Carlos Pascual. "Addressing State Failure." Foreign Affairs, vol. 84, no. 4 (July/August 2005).

Krueger, Alan B., and David D. Laitin. "Misunderestimating Terrorism': The State Department's Big Mistake.” Foreign Affairs, vol. 83, no. 5 (September/October 2004).

Lasswell, Harold. "The Garrison State." American Journal of Sociology, vol. 46, no. 4 (January 1941). 
Legault, Albert, and Joel Sokolsky (ed.). The Soldier and the State in the Post Cold-War Era. A special issue of the Queen's Quarterly (2002).

Legault, Albert. "Civil-Military Relations: Democracy and Norm Transfer." In The Soldier and the State in the Post Cold-War Era, ed. Albert Legault and Joel Sokolsky. A special issue of the Queen's Quarterly (2002).

Macdonald, Lt.-Gen. (ret'd) George. “Canada-US Defence cooperation: Where to from here." Canadian Military Journal, vol. 6, no. 2 (Summer 2005).

Maior, George Cristian. "Nu intram in NATO pentru a beneficia de securitate, ci pentru a participa la crearea securitatii." Gandirea militara romaneasca, no. 1/2002.

Maior, George. "Transformarea politicii de aparare a Romaniei: Trei teme de reflectie strategica." ISPAIM Occasional Papers (Bucharest), no. 5 (III)/2004.

Marsh, Col. Howie. "CDA Annual General Meeting," On Track, vol. 9, no. 1 (March 2004).

Maloney, Sean M. "Force Structure or Forced Structure?" Choices, vol. 10, no. 5 (May 2004).

Maloney, Sean M. "Who Has Seen the Wind? A Historical Overview of Canadian Special Operations." Canadian Military Journal, vol. 5, no. 3 (Autumn 2004).

Muresan, Liviu. "Security Sector Reform: An Opportunity for Euro-Atlantic Integration of Romania." DCAF Working Papers, no. 11 (April 2002).

Nastase, Dorina Maria. "Strategia nationala de securitate: de la aparare teritoriala la securitate umana?" Revista 22, year XIV, no. 825 (December 27, 2005-January 2, 2006).

Naumann, Col. Klaus. "The Responsibility to Protect - Humanitarian Interventions and the Use of Military Force." Canadian Military Journal, vol. 5, no. 4 (Winter 2004-2005).

Nelson, Daniel N. "Definition, Diagnosis, Therapy: A Civil-Military Critique." Defense \& Security Analysis, vol. 18, no. 2 (2002).

Pascu, Ioan Mircea. "Securitatea Romaniei se apara si la mare distanta de tara." Observatorul militar, no. 3 (January 21-27, 2004).

Perry, William J. "Preparing for the Next Attack." Foreign Affairs, vol. 80, no. 6 (November/December 2001).

Popescu, Gen. Mihail. "Prefacerea organismului militar romanesc corespunde nevoilor de aparare ale Romaniei." Gandirea militara romaneasca, no. 1/2003. 
Potter, William C., et al. "The Four Faces of Nuclear Terror." Foreign Affairs, vol. 83, no. 3 (May/June 2004).

Richter, Andrew. "Towards a More Strategic Future? An Examination of the Canadian Government's Recent Defence Policy Statements." Canadian Military Journal, vol. 7, no. 1 (Spring 2006).

Robertson, R. G. "The Changing Role of the Privy Council Office." Canadian Public Administration, vol. XIV, no. 4 (1971).

Rumsfeld, Donald H. "Transforming the Military." Foreign Affairs, vol. 81, issue 3 (May/June 2002).

Saul, John Ralston. "A New Era of Irregular Warfare?" Canadian Military Journal, vol. 5, no. 4 (Winter 2004-2005).

Schiff, Rebecca L. "Civil-Military Relations Reconsidered: A Theory of Concordance." Armed Forces \& Society, vol. 22, no. 1 (Fall 1995).

Schiff, Rebecca L. "Concordance Theory: A Response to Recent Criticism." Armed Forces \& Society, vol. 23, no. 2 (Winter 1996).

Segal, Hugh. "A Grand Strategy for a Small Country." Canadian Military Journal, vol. 4, no. 3 (Autumn 2003).

Segal, Hugh. "The Canadian-American Defence Relationship: Nostalgia Ain't What It Used to Be." Policy Options, vol. 23, no. 3 (April 2002).

Shadwick, Martin. "Defence and the Conservatives." Canadian Military Journal, vol. 7, no. 1 (Spring 2006).

Shadwick, Martin. "The Chrétien Legacy." Canadian Military Journal, vol. 4, no. 4 (Winter 2003-2004).

Simon, Jeffrey. "East Bloc Military Must Be Civilian Led." Aviation Week \& Space Technology, vol. 143, no. 10 (September 4, 1995).

Sloan, Elinor. "Beyond primacy: American grand strategy in the post-September 11 era." International Journal, vol. 58, issue 2 (Spring 2003).

Sloan, Elinor. "Terrorism and the Transformation of US Military Forces." Canadian Military Journal, vol. 3, no. 2 (Summer 2002).

Sokolsky, Joel J. “Clausewitz, Canadian Style?” Canadian Military Journal, vol. 3, no. 3 (Autumn 2002). 
Sokolsky, Joel J. "Northern exposure? American homeland security and Canada." International Journal, vol. 60, issue 1 (Winter 2004/2005).

Thorne, Stephen. "Rick Hillier." International Journal, vol. 60, no. 3 (Summer 2005).

Watts, Larry. "Reform and Crisis in Romanian Civil-Military Relations: 1989-1999." Armed Forces and Society, vol. 27, no. 4 (Summer 2001).

Watts, Larry L. "The Crisis in Romanian Civil-Military Relations." Problems of PostCommunism, vol. 48, no. 4 (July/August 2001).

Wells, Richard S. "The Theory of Concordance in Civil/Military Relations: A Commentary." Armed Forces \& Society, vol. 23, no. 2 (Winter 1996).

***. Confruntarile asimetrice." Gandirea militara romaneasca, no. 4/2002.

***. "Romania's National Security Dilemma." The Romanian Digest, vol. X, no. 9 (September 2005).

\section{Non-refereed articles}

Adam, Mohammed. "Canada must expect attack: McLellan." Ottawa Citizen, July 12, 2005.

Adam, Mohammed. "Prepare for catastrophe or pay with lives: reports." Ottawa Citizen, Nov. 27, 2004.

Alberts, Sheldon. "Canada set to beef up Afghan presence." National Post, Nov. 24, 2004.

Aldea, Anca. "Eugen Badalan: Armata nu face politica partizana." Jurnalul national, July $4,2006$.

Ames, Paul. "UN chief warns of global terror threat." Ottawa Citizen, February 14, 2005.

Artene, Adrian. "Romania, plasata pe axa de actiune a unor organizatii teroriste." Libertatea, January 24, 2005.

B., A. M. "Romania, o tinta pentru teroristi, ca orice democratie." Gandul, July 13, 2005.

Bell, Stewart. "Al-Qaeda could spread avian flu, report warns." National Post, October 25,2005

Bell, Stewart. "CSIS breaks up terror cell." National Post, November 3, 2005. 
Bell, Stewart. "Deportations put Canada at risk of attack." National Post, Nov. 22, 2004.

Bell, Stewart. "Terror Financing on the Rise," National Post, October 5, 2006.

Bell, Stewart. "Terrorism Threat Unabated." National Post, September 29, 2005.

Blanchfield, Mike. "Canada told U.S. in June it backs missile shield." Ottawa Citizen, January 14, 2005.

Blanchfield, Mike. "Chrétien cut Forces too deep: Collenette." Ottawa Citizen, December 14, 2004.

Blanchfield, Mike. "Government, not generals, will decide mission: Harper." National Post, March 8, 2006.

Blanchfield, Mike. "Liberals defend \$5B purchase of 16 planes." National Post, November 23, 2005.

Blanchfield, Mike. “We like a good punch-up."' Ottawa Citizen, September 26, 2004.

Blanchfield, Mike. "We'll make good on our promises of more money, more troops, Graham insists." Ottawa Citizen, September 25, 2004.

Blanchfield, Mike, and Aileen McCabe. "Military leaders confident budget will offer \$1B extra." Ottawa Citizen, February 15, 2005.

Brewster, Murray. "Military worried about Tory failure to defend Afghan mission." The Canadian Press, October 1, 2006.

Butler, Don. "How middle-class westerners are turned into human bombs." Ottawa Citizen, July 14, 2005.

Campion-Smith, Bruce. "Aging navy at risk, Senate warned." Toronto Star, February 15, 2005.

Chiriac, Marian. "Romania wary of probe into illegal prisons." Taiwan News, December 19, 2005.

Costache, Bogdan. "Armata nu are bani de NATO." Adevarul, October 14, 2005.

Crisan, Raluca. "Atuurile lui Teodor Atanasiu: vanatorii de munte si spionii." Evenimentul zilei, January 17, 2005.

den Tandt, Michael. "O'Connor denies rift with Hillier delaying military purchases." The Globe and Mail, May 4, 2006. 
den Tandt, Michael. "Ottawa seeks closer watch on top general." The Globe and Mail, April 19, 2006.

Diac, Mihai. "Conducerea Armatei spera ca numarul generalilor va creste." Adevarul, March 14, 2005.

Diac, Mihai. "Pe teritoriul Romaniei sunt prezente zece grupari teroriste." Gandul, May $27,2005$.

Dragomir, Doru. “Atanasiu: Adio, racani!” ZIUA, October 24, 2005.

Dragomir, Doru. "Pe doua limbi." ZIUA, April 18, 2006.

Duffy, Andrew. "Canada has sleeper cells: Moroccan terrorist." Ottawa Citizen, July 14, 2005.

Fergusson, Niall. “2011.” The New York Times Magazine, December 2, 2001.

Fife, Robert. "Budget to include funds for Armed Forces to recruit 5,000 troops." Ottawa Citizen, December 15, 2004.

Foot, Richard. "On board of the navy's fragile flagship." Ottawa Citizen, November 20, 2004.

Foot, Richard. "Tug of War." Ottawa Citizen, September 25, 2004.

Friedman, Thomas L. "America's failure of imagination." The New York Times, May 20, 2002.

Galloway, Gloria. "Controversy takes flight on \$8.3-billion plan for planes." The Globe and Mail, June 30, 2006.

Galloway, Gloria. "Experts caution al-Qaeda may hit at targets in Canada." The Globe and Mail, July 9, 2005.

Gardner, Dan. "Irrational spending in the Age of Terror." Ottawa Citizen, February 19, 2005.

Geddes, John. "Bullets fly. Ottawa ducks." Maclean's, August 28, 2006.

Geddes, John. "Canada in Combat." Maclean's, March 20, 2006.

Ghafour, Hamida. "Escalating violence has roots beyond Taliban." The Globe and Mail, January 17, 2006. 
Gilroy, Rob. "Canada should heed bin Laden's warning: Experts." CTV News, November $14,2002$.

Glenn, Jack. "Harper right on Hillier." The Globe and Mail, April 22, 2006.

Goldstone, Jack A., et al. Internal Wars and Failures of Governance: 1955-2002.

http://www.cidcm.umd.edu/inscr/stfail/index.htm, May 18, 2004 (accessed December 28, 2005).

Goodspeed, Peter. "Canada seen as having 'soft belly,' terror expert says: 'Very worthy target." National Post, November 3, 2005.

Goodspeed, Peter, and Stewart Bell. "Involvement of Canadian Agencies Unclear." National Post, March 24, 2006.

Gordon, James. "New military chief attacks underfunding." Ottawa Citizen, February 5, 2005.

Gray, John. "What do we want the Canadian military to do?" CBC News, May 12, 2006.

Dyer, Gwynne. "If 9/11 Hadn't Happened." http://gwynnedyer.net/, September 2, 2006 (accessed August 22, 2007).

Dyer, Gwynne. "Perspectives on Terrorism." http://gwynnedyer.net/, July 1, 2007 (accessed August 22, 2007).

Dyer, Gwynne. "The International Terrorist Conspiracy." http://gwynnedyer.net/, June 3, 2006 (accessed August 22, 2007).

Hanley, Charles. “This war will be 'endless,' terrorism experts say." Ottawa Citizen, July $10,2005$.

Haydon, Peter. "We can't afford to let our navy rust out." Natiomal Post, Nov. 29, 2004.

Harris, Kathleen. "Sacrifice and risk' vital, PM warns." The Ottawa Sun, September 12, 2006.

Harris, Kathleen. "Tories shoot down missile defence." The Ottawa Sun, October 6, 2006.

Harris, Kathleen. "We cannot afford to fail." The Ottawa Sun, September 22, 2006.

Homer-Dixon, Thomas. "The Argument." http://www.theupsideofdown.com/, 2006 (accessed October 15, 2007).

Hriban, Anca. "Basescu, vizita secreta in Irak si Afganistan." ZIUA, March 29, 2005. 
Hriban, Anca. "Legea CSAT are forma dorita de Iliescu." ZIUA, June 19, 2002.

Jackson, Robert J. "Bureaucrats with guns: Canada's secret weapon." Ottawa Citizen, July 19, 2007.

Kenny, Colin. "Rebuilding a country." Ottawa Citizen, June 10, 2005.

Krauss, Clifford. "NORAD in Jeopardy: Experts." National Post, February 28, 2005.

Kymlicka, Will. "Panarchy and dystopia." The Globe and Mail, November 11, 2006.

La Guardia, Anton. "UN told to take tougher stand against terror." The Daily Telegraph, November 30, 2004.

Leblanc, Daniel. "General's talk of terrorist 'scumbag' praised." The Globe and Mail, July $16,2005$.

Leight, David, and Rob Evans. "Bribery inquiry may force $£ 7 \mathrm{~m}$ refund to Romania." The Guardian, June 15, 2006.

Lupea, Ioana. "Moarte in Irak." Evenimentul zilei, April 28, 2006.

MacAffee, Michelle. "Sheila Fraser on the Canadian Forces." CNEWS, December 4, 2001.

Macdonald, L. Ian. "A problem of communication." The Gazette, August 1, 2007.

MacKenzie, Maj.-Gen. (ret'd) Lewis. "Peacemaking is Not Social Work." National Post, Nov. 23, 2004.

Macleod, Ian. "Officials pore over Taliban 'grads' video." Ottawa Citizen, June 20, 2007.

Marascu, O., et al. "Arestarea teroristului-butelie.” ZIUA, June 28, 2006.

Margarit, Gen. (ret'd) Mihaiu. "Strategia de securitate, un eseu." Jurnalul national, March 9, 2006.

Martin, Don. "Showdown over military's direction rankles top general." The Gazette, February 16, 2007.

McGregor, Glen. "Judging terrorism's real threat to Canada." Ottawa Citizen, December 14, 2004. 
Mueller, John . Quoted in Terror Nation: Are Americans Allowing Terrorists to Rule Their Lives?, by John Stossel and Gena Binkley, http://abcnews.go.com/2020/story?id=2895849\&page=1, February 23, 2007 (accessed August 22, 2007).

Mutler, Alison. "Former Romanian minister says part of base used by U.S. troops offlimits to Romanians." Associated Press, November 21, 2005.

Mutler, Alison. "Romania May Withdraw Its Troops from Iraq." Associated Press, June 29, 2006.

Nunn, Sam. "Last Best Chance." http://www.nti.org, 2005 (accessed August 15, 2005).

O’Neil, Peter. "Martin denies missile shield is a top issue." Ottawa Citizen, November $15,2004$.

Oprea, Cristian. "Pascu, suparat ca militarii fac politica." Evenimentul zilei, April 26, 2003.

Panetta, Alexander. "Internal documents hint at military's discontent with Tory repatriation policy." The Canadian Press, July 2, 2006.

Palade, Gabriela. "Serviciile speciale ne costa 338 milioane de euro." Evenimentul zilei, November 2, 2004.

Pellerin, Grigitte. "Help for our reserves." National Post, September 9, 2005.

Pol, Anca. "Gear Up: Basescu Tells Army." The Diplomat, April 2006.

Prager, Jacqueline, and Calin Cosmaciuc. "Romania, halta CIA." Evenimentul zilei, November 20, 2005.

Pugliese, David. "Canada to get its own version of Green Berets." Winnipeg Free Press, January 3, 2006.

Pugliese, David. “Canada's 'Analysis Paralysis.”" Ottawa Citizen, September 27, 2004.

Pugliese, David. “Command Performance." Ottawa Citizen, September 4, 2007.

Pugliese, David. "From peacekeepers to Taliban hunters." Ottawa Citizen, March 25, 2006.

Pugliese, David. "Missile shield could use our money, land." Ottawa Citizen, Dec. 3, 2004.

Pugliese, David. "Time to protect the homeland." Ottawa Citizen, October 2, 2004. 
Rizzo, Russ. "Romania moving closer to base access deal with U.S." Stars and Stripes, July 25, 2005.

Rubec, Stephanie. “'We can't let up' on terror.” Edmonton Sun, July 15, 2005.

Sliva, Jan. "Secret CIA Flights Stopped in Two Countries." Associated Press, July 6, 2006.

Stossel, John, and Gena Binkley. Terror Nation: Are Americans Allowing Terrorists to Rule Their Lives? http://abcnews.go.com/2020/story?id=2895849\&page=1, February 23, 2007 (accessed August 22, 2007).

Thorne, Stephen. "Air force is pushed past limit, Ottawa told." The Globe and Mail, February 8, 2005.

Thorne, Stephen. "Defence minister rips military paper." The Canadian Press, February $11,2005$.

Thorne, Stephen. 'London attacks underscore Canada's need to be in Afghanistan: Hillier." National Post, July 14, 2005.

Toader, Mihai. "Dovada puciului." ZIUA, July 1, 2006.

Toader, Mihai, and Razvan Gheorghe. "Premierul jucator." ZIUA, June 30, 2006.

Trandafir, Gelu. "Atanasiu, un ministru depasit de misiune." Romania libera, August 8, 2006.

Travers, James. "PM uses Afghanistan mission as a wedge political issue." The Hill Times, April 30, 2007.

Tudor, Radu. "10\% More for the Military Budget Next Year." Jurnalul national, October $1,2005$.

Tudor, Radu. “Armata in razboi." ZIUA, June 21, 2005.

Tudor, Radu. "Batalion romanesc de informatii militare." ZIUA, November 15, 2005.

Tudor, Radu. "Brigada Antiterorista din Romania isi extinde cooperarea in lupta impotriva terorismului." http://www.sri.ro, January 2002 (accessed June 26, 2005).

Tudor, Radu. "Europa in razboi." ZIUA, July 8, 2005.

Tudor, Radu. "Interventia, esecul prevenirii terorismului." Jurnalul national, October 8, 2005. 
Tudor, Radu. "Prea multi generali." ZIUA, March 10, 2005.

Tudor, Radu. "Tampenie si tradare." Jurnalul national, July 4, 2006.

Walton, David. "Security forces can confront terror threat head on, PM says." The Globe and Mail, June 10, 2006.

Ward, John. "Military can't afford basic bullets and beans." The Canadian Press, February 24, 2006.

Wattie, Chris. "Why $\$ 13.6 \mathrm{~B}$ a year isn't enough to run our military." Ottawa Citizen, September 28, 2004.

***. "10 terrorist plots detected: Bush." CBC News, October 6, 2005.

***. "Armata Romana este 'prost dotata." Gandacul de Colorado, no. 54 (July 2006).

***. "Canada and United States Commit to Renewed Defence Cooperation." Canada NewsWire, November 29, 2004.

***. "Canada says to hunt down al-Qaeda in Afghanistan." Reuters, July 15, 2005.

***. "Canada warns of avian influenza used as weapon." http://www.chinaview.cn, March 9, 2005 (accessed March 9, 2005).

***. "Canadian Forces chief says the public, not politicians, will save the military." The Brandon Sun, November 25, 2005.

***. "Canadians ill-informed about Afghan mission: Fraser." The Canadian Press, December 5, 2006.

***. "Chrétien government rejected military's advice on Afghan deployment: ex-army chief." CBC News, October 18, 2006.

***. "CSAT a aprobat strategia de securitate nationala." BBC Romania, April 17, 2006.

***. "Document outlines Canada's military plans in Afghanistan." CBC News, January $28,2007$.

***. "Fresh thinking on missile defence." National Post, January 16, 2006.

***. "Harper must deal with Hillier and O'Connor." The Intelligencer, August 2, 2007.

***. "Generals will determine Afghan stay: MacKay." Toronto Star, March 6, 2006.

***. "Hillier rebukes Liberals." Metro Ottawa, February 1, 2006. 
***. "Micile secrete ale lui... Teodor Atanasiu." http://www.hotnews.ro, September 8, 2006 (accessed September 8, 2006).

***. "Missile defence talks important for Canada: Graham." CBC News, September 23, 2004.

***. "O’Connor, Hillier out of step on issues: critics." CTV News, July 31, 2007.

***. "Red Cross Calls for Strengthening of Biological Weapons Treaty to Better Regulate Against Weapons Programs." http://www.nti.org, 2005 (accessed September 20, 2005).

***. "Romania Removes Top General from Key Post." Associated Press, May 28, 2005.

***. “'Stopped a Madrid,' British police say." The Globe and Mail, December 9, 2004.

***. "Terrorist WMD Attacks Might Not Cause Mass Casualties, British Scientists Say." http://www.nti.org, 2005 (accessed August 24, 2005).

***. "The New Taliban." The Globe and Mail, January 17, 2006.

***. "The Right Note." Maclean's, September 25, 2006.

***. "The uncertain leadership of Canada's Paul Martin." The Economist, February 17, 2005.

***. “Top general's comments anger Liberals.” Toronto Star, February 16, 2007.

***. "Traian Basescu propune internationalizarea Marii Negre." ZIUA, June 24, 2005.

***. 'U.N. Must Sharpen Response to Evolving 'Third Generation' al-Qaeda Tactics, Report Says." http://www.nti.org, 2005 (accessed September 21, 2005).

\section{Primary sources and interviews}

Atanasiu, Teodor (Minister of National Defence of Romania). Interview. "An Army of Professionals." Romanian Military Newsletter, February 14, 2005.

Badalan, Gen. Eugen (Chief of the General Staff of the Romanian Armed Forces). Interview by Alina Grigore. "Relatia cu NATO, afectata de scandalurile din MApN." Prezent, June 19, 2007. 
Badalan, Gen. Eugen (Chief of the General Staff of the Romanian Armed Forces). Interview by Claudiu Tarziu and Simona Popa. "Atanasiule, plecam impreuna." Cotidianul, September 17, 2007.

Calder, Kenneth (former Assistant Deputy Minister, Policy, Department of National Defence, Canada). Interview by the author. Ottawa, ON, July 9, 2008.

Cioculescu, Serban (Researcher, Monitor strategic). Interview by the author. Bucharest, Romania, April 18, 2005.

Degeratu, Dan Claudiu (Director General, Department of Defence Policy, Ministry of National Defence, Romania). Interview by the author. Bucharest, Romania, April 18, 2005.

Department of Finance (Canada). Budget 2006: Focusing on Priorities. http://www.fin.gc.ca/budtoce/2006/budliste.htm, May 2, 2006 (accessed May 2, 2006).

Department of National Defence (Canada). Canada and United States Amend NORAD Agreement. http://www.dnd.ca/site/Newsroom/view news e.asp?id=1422, August 5, 2004 (accessed September 10, 2004).

Department of National Defence (Canada). Defence Policy Statement. http://www.forces.gc.ca/site/reports/dps/index e.asp, 2005 (accessed March 10, 2006).

Frunzaverde, Sorin (Minister of National Defence of Romania). Interview. "Vom respecta angajamentele asumate fata de aliati." Observatorul militar, no. 2/2007 (January 17-23).

Frunzeti, Maj.-Gen. Teodor. Interview by Capt. Marian Predoaica. "Armata - institutie de prestigiu a statului." Spirit militar modern, no. 1-2/2005.

Fulga, Gheorghe (Chief of the Foreign Intelligence Service, SIE, Romania). Interview by Radu Tudor. "Interviu acordat de directorul SIE, dr. Gheorghe Fulga, reporterului cotidianului ZIUA, Radu Tudor, la 26 noiembrie 2004." http://www.sie.ro, November 26, 2004 (accessed July 2, 2005).

Fulga, Gheorghe (Chief of the Foreign Intelligence Service, SIE, Romania). "Climatul de securitate in regiunea Marii Negre extinse dupa 11 septembrie 2001." http:/www.sie.ro, 2005 (accessed June 26, 2005).

Fulga, Gheorghe (Chief of the Foreign Intelligence Service, SIE, Romania). "Combaterea terorismului international si a criminalitatii organizate transfrontaliere." http://www.sie.ro, 2005 (accessed June 26, 2005).

Fulga, Gheorghe (Chief of the Foreign Intelligence Service, SIE, Romania). "Romania si mediul regional de securitate." http://www.sie.ro, 2005 (accessed September 10, 2005). 
Government of Romania. Romania on Its Way to NATO. Bucharest: Government of Romania, 2002.

Guvernul Romaniei. Carta Alba a Securitatii si Apararii Nationale. Bucharest: Guvernul Romaniei, 2004.

Harris, David. Interview by Linda Frum. Maclean's, June 19, 2006.

Hillier, Gen. Rick (Chief of the Defence Staff of the Canadian Forces). Interview by John Geddes. "If we don't bring stability to places like Afghanistan, they will bring instability to Canada."' Maclean's, April 11, 2005.

Hillier, Gen. Rick (Chief of the Defence Staff of the Canadian Forces). Interview by Sharon Hobson. "Interview: General Rick Hillier, Canadian Forces Chief of the Defence Staff." Jane's Defence Weekly, August 9, 2006.

Hillier, Gen. Rick (Chief of the Defence Staff of the Canadian Forces). Interview by Wendy Mesley. www.cbc.ca (The National), April 15, 2008 (accessed April 17, 2008).

Iliescu, Ion (President of Romania). “Taking No Chances.” Transitions On-Line. http://www.tol.cz, November 21, 2002 (accessed November 21, 2002).

Independent Panel on Canada's Future Role in Afghanistan. http://www.independentpanel-independant.ca/main-eng.html, January 2008 (accessed February 2, 2008).

Ioan, Lt.-Gen. Sorin. Interview by Col. Francisco Stoica. "Vom valorifica experienta acumulata in teatre." Observatorul militar, nr. 42 (October 19-25, 2005).

Ionescu, Mihail (Director, Institute for Political Studies of Defence and Military History). Interview by the author. Bucharest, Romania, April 18, 2005.

Jeffery, Lt.-Gen. (ret'd) Mike. Interview. "Interview with Lt.-Gen. (ret'd) Mike Jeffery." National Network News, vol. XI, no. 2 (Fall 2004).

Lamberti, Alba (EU Liaison Manager, International Crisis Group). Interview by the author. Brussels, Belgium, April 8, 2005.

Marin, Adm. Gheorghe (Chief of the General Staff of the Romanian Armed Forces). Interview by Lt.-Col. Leonard Mocanu. "Armata trebuie privita ca un organism viu," Observatorul militar, no. 17/2007 (May 3-9).

MacKay, Peter (Minister of Foreign Affairs of Canada). Interview by Kenneth Whyte. "We're not a country that lives in splendid isolation." Maclean's, August 7, 2006. 
Martin, Paul (Prime Minister of Canada). "Making a Difference." In Canada's International Policy Statement: A Role of Pride and Influence in The World (Overview), http://www.dfait-maeci.gc.ca/cip-pic/IPS/IPS-Overview.pdf, 2005 (accessed March 8, 2006).

Muresan, Gen. Mircea. Interview by Col. Cosinel Petrache. "Structura de Forte 2007 va fi rezultatul nevoilor reale ale apararii nationale." Gandirea militara romaneasca, no. $3 / 2003$.

National Commission on Terrorist Attacks Upon the United States. 9/11 Commission Report. http://govinfo.library.unt.edu/911/report/index.htm 2004 (accessed February 12, 2005).

Popescu, Gen. Mihail (Chief of the General Staff of the Romanian Armed Forces). Interview by Col. Ion Petrescu. "Romania are, in Armata, un pilon de nadejde!" Observatorul militar, no. 42 (October 21-27, 2004).

Popescu, Gen. Mihail. "Starea Armatei Romaniei: Reforma si Integrare." http://www.mapn.ro, October 25, 2004 (accessed December 20, 2004).

Popescu, Mihail. "Trupele armatei romane nu pot fi considerate trupe de ocupatie in Irak." http://www.senat.ro, March 21, 2005 (accessed June 10, 2007).

Popescu Tariceanu, Calin (Prime Minister of Romania). Interview. "Intarirea credibilitatii armatei." Observatorul militar, vol. 14/2007 (April 12-17).

Parlamentul Romaniei. Constitutia Romaniei. http://www.cdep.ro/pls/dic/site.page?id=339, 2003 (accessed May 23, 2007).

Presedintele Romaniei. Strategia de Securitate Nationala a Romaniei. Bucharest: Presedintele Romaniei, 2006.

Presedintele Romaniei. The National Security Strategy of Romania: Safeguarding Democracy and Fundamental Freedoms, Sustainable Economic and Social Development, and Integration into NATO and the European Union. Bucharest: Presedintele Romaniei, 2001.

Privy Council Office. Securing an Open Society: Canada's National Security Policy. http://www.pco-bcp.gc.ca/docs/Publications/NatSecurnat/natsecurnat e.pdf, April 2004 (accessed March 11, 2006).

Privy Council Office. The Role and Structure of the Privy Council Office. http://www.pcobcp.gc.ca/default.asp?Page $=$ Publications\&Language $=E \& d o c=$ Role/role e.htm, February 1999 (accessed March 15, 2006). 
Revelas, Kyriakos (Principal Administrator, Security Policy Unit, DG External Relations, European Commission). Interview by the author. Brussels, Belgium, April 7, 2005.

Shea, Jamie (Spokesperson, North Atlantic Treaty Organization). "The Impact of September $11^{\text {th }}$ on the Alliance." http://www.nato.int/docu/speech/2004/s040112a.htm, January 12, 2004 (accessed August 15, 2005).

Tinca, Stefan (Security and Defence Expert, Mission of Romania to the European Union). Interview by the author. Brussels, Belgium, April 7, 2005.

United States Department of State. Background Note: Romania. http://www.state.gov/r/pa/ei/bgn/35722.htm, December 2005 (accessed June 5, 2006).

United States Department of State. Country Reports on Terrorism 2004. Washington, DC: US Department of State, 2005.

United States Department of State. "State Department Identifies 40 Foreign Terrorist Organizations." http://usinfo.state.gov/is/Archive/2005/Apr/27-320736.html, April 27, 2005 (accessed September 8, 2005).

Vexler, Dan (Research Manager, International Crisis Group). Interview by the author. Brussels, Belgium, April 8, 2005.

Watts, Larry (Security and Defence Advisor, Presidential Administration of Romania). Interview by the author. Bucharest, Romania, April 15, 2005.

Zulean, Marian (Security and Defence Advisor, Presidential Administration of Romania). Interview by the author. Bucharest, Romania, April 15, 2005.

***. "A Time for Transformation: Annual Report of the Chief of the Defence Staff (2002-2003)." http://www.cds.forces.gc.ca/pubs/anrpt2003/intro e.asp, 2003 (accessed April 18, 2006).

***. "Address by Prime Minister Paul Martin at Pier 21, Halifax." http://www.news.gc.ca/cfmx/view/en/index.jsp?articleid=113169\&keyword=pier+21\&ke yword=pier+21\&, December 1, 2004 (accessed November 21, 2005).

***. "Alocutiunea Presedintelui Romaniei, domnul Traian Basescu." http://www.mapn.ro, December 29, 2004 (accessed February 11, 2005).

***. "Alocutiuni cu prilejul investirii in functie a noului ministru al apararii nationale." http://www.mapn.ro, December 29, 2004 (accessed December 29, 2004).

***. "Annual Report of the Chief of the Defence Staff (2001-2002)." http://www.cds.forces.gc.ca/pubs/anrpt2002/intro e.asp, 2002 (accessed April 18, 2006). 
***. "Backgrounder: Canada Command."

http://www.forces.gc.ca/site/Newsroom/view news e.asp?id=1692, June 28, 2005 (accessed March 14, 2006).

***. "Canada's Fight against Terror."

http://www.canadianally.com/ca/terror/terror military-en.asp, February 3, 2006 (accessed March 14, 2006).

***. "Canada's International Policy Statement: A Role of Pride and Influence in The World." http://www.dfait-maeci.gc.ca/cip-pic/IPS/IPS-Overview.pdf, 2005 (accessed March 8, 2006).

***. "Centrul de Coordonare Operativa Antiterorista. Informare de presa. Evaluare pe trimestrul I/2004." http://www.sri.rol, 2004 (accessed December 7, 2004).

***. "Combaterea terorismului international in acceptiunea SIE." http://www.sie.ro, 2005 (accessed June 26, 2005).

***. "Commander Speaks about Army Transformation."

http://www.forces.gc.ca/site/Newsroom/view news e.asp?id=1239, October 30, 2003 (accessed October 15, 2004).

***. "Comunicat de presa." http://www.presidency.ro, February 28, 2005 (accessed February 28, 2005).

***. "Comunicat de presa." http://www.presidency.ro. September 15, 2005 (accessed September 20, 2005).

***. "Conferinta de presa." http://www.mapn.ro, January 8, 2002 (accessed June 14, 2006).

***. "Conferinta de presa." http://www.mapn.ro, August 21, 2002 (accessed June 20, 2006).

***. "Conferinta de presa." http://www.mapn.ro/briefing/030626/conferinta 030626.htm, June 26, 2003 (accessed May 31, 2006).

***. "Conferinta de presa a ministrului apararii nationale." http://www.mapn.ro, June 1, 2006 (accessed July 1, 2006).

***. "Conferinta de presa a sefului Statului Major General." http://www.mapn.ro, April 22, 2002 (accessed June 10, 2006).

***. "Conferinta de presa la MApN." http://www.mapn.ro, June 26, 2003 (accessed July $3,2004)$. 
***. "Making Choices: Annual Report of the Chief of the Defence Staff (2003-2004)." http://www.cds.forces.gc.ca/pubs/anrpt2004/intro_e.asp, 2004 (accessed April 18, 2006).

***. "Mesajul domnului Ion Iliescu, Presedintele Romaniei cu ocazia Zilei Armatei Romaniei." http://www.mapn.ro, October 25, 2004 (accessed October 25, 2004).

***. "Operation ATHENA: The Canadian Forces Participation in ISAF." http://www.forces.gc.ca/site/Newsroom/view news e.asp?id=1228, August 27, 2004 (accessed November 3, 2004).

***. "Prague Summit Declaration." http://www.nato.int/docu/pr/2002/p02-127e.htm, November 21, 2002 (accessed December 5, 2005).

***. "Press Communique." http://www.presidency.rol, July 11, 2005 (accessed July 20, 2005).

***. "Proiectul strategiei nationale de prevenire si combatere a terorismului - aproape de finalizare." http://www.sri.ro/, February 7, 2002 (accessed December 7, 2004).

***. "Response to Terrorism." http://www.nato.int/docu/briefing/rtt-e.pdf, March 2005 (accessed January 5, 2006).

***. "Speaking Notes for The Honourable John McCallum, P.C., M.P. Minister of National Defence at the Standing Committee on National Defence and Veterans Affairs." http://www.forces.gc.ca/site/Newsroom/view_news_e.asp?id=1252, November 6, 2003 (accessed March 22, 2007).

***. "Transform and modernize the Canadian Forces." http://cds.forces.gc.ca/cfttfc/intro e.asp, April 2006 (accessed April 18, 2006).

\section{Papers presented at professional meetings and conferences}

Charters, David A. "The Impact of the War on Terrorism on the Canadian-American Security Relationship." Paper presented at the conference Canadian Defence and the Canada-U.S. Strategic Partnership, organized by the Centre for Security and Defence Studies (CSDS) at Carleton University, the Calgary-based Canadian Defence \& Foreign Affairs Institute (CDFAI) and the Center for the Study of the Presidency in Washington, DC, Lord Elgin Hotel, Ottawa, September 5-6, 2002.

de B. Taillon, Paul. "The Evolving Requirements of the Canadian SOF." Paper presented at the Third War Studies Symposium Global Insurgency, Terrorism and Special Operations in the $21^{\text {st }}$ Century, organized by the Royal Military College of Canada and the Joint Special Operations University (USA), Kingston, ON, October 20, 2004. 
Elcock, Ward. "The Future Threat Environment." Keynote address delivered to the Third War Studies Symposium Global Insurgency, Terrorism and Special Operations in the $21^{\text {st }}$ Century, organized by the Royal Military College of Canada and the Joint Special Operations University (USA), Kingston, ON, October 20, 2004.

Hillier, Gen. Rick. "Setting Our Course." Speech presented to the Canadian Institute for Strategic Studies Conference, Toronto, July 22, 2005.

Hoffman, Frank. "Dereliction of Duty Redux?" Paper presented at the conference 'Mind the Gap': Post-Iraq Civil-Military Relations in America, sponsored by the Foreign Policy Research Institute and the Reserve Officers Association, Washington, DC, October 15, 2007, www.fpri.org (accessed November 25, 2007).

Lagassé, Philippe, and Joel J. Sokolsky. “A Larger 'Footprint' in Ottawa: Canada's Evolving Civil-Military Relationship." Paper presented at the International Studies Association's $49^{\text {th }}$ Annual Convention Bridging Multiple Divides, San Francisco, CA, March 26, 2008.

Last, David, et al. "Evaluating National Security in the Context of Terrorism: What Do Our Leaders Expect of Us?." Paper presented at the Third War Studies Symposium Global Insurgency, Terrorism and Special Operations in the $21^{\text {st }}$ Century, organized by the Royal Military College of Canada and the Joint Special Operations University (USA), Kingston, ON, October 20, 2004.

Leslie, Maj.-Gen. Andrew. "Conventional Forces Doing Special Things: Afghanistan and Lessons for the Future." Paper presented to the Third War Studies Symposium Global Insurgency, Terrorism and Special Operations in the $2 I^{\text {st }}$ Century, organized by the Royal Military College of Canada and the Joint Special Operations University (USA), Kingston, ON, October 20, 2004.

Leslie, Maj.-Gen. Andrew. "Thoughts on the Future of the Canadian Forces." Paper presented at the $74^{\text {th }}$ Annual Couchiching Summer Conference Handcuffs and Hand Grenades: The Use of Force Within and Between Nations, Willowdale, ON, August 7, 2005.

Lyon, Ron. "Civil-Military Relations in an Age of Terror." Paper presented at the symposium Civil-Military Relations in an Age of Terror, organized by the University of Queensland, Brisbane, July 5-7, 2004, http://ics.leeds.ac.uk/papers/pmt/exhibits/2290/lyon.pdf (accessed January 5, 2005).

MacKenzie, Maj.-Gen. (ret'd) Lewis. "Security and Defence.” Keynote address delivered to the Seventh Annual Graduate Student Symposium Security and Defence: National and International Issues, organized by the Conference of Defence Associations Institute and the Canadian Defence and Foreign Affairs Institute, Kingston, ON, October 29, 2004. 
McLellan, Anne. "Securing Canada: Laying the groundwork for Canada's first National Security Policy." Speaking notes to the Canadian Club of Ottawa, Ottawa, March 25, 2004.

Nastase, Adrian. Opening remarks to the summit The Spring of New Allies, organized by the North Atlantic Treaty Organization, Bucharest, Romania, March 25, 2002. Cited in Government of Romania. Romania on Its Way to NATO. Bucharest: Government of Romania, 2002.

Rigby, Vincent. Presentation to the conference Terrorism, Democracy and Empire, organized by Carleton University, Ottawa, October 1, 2005.

Rotberg, Robert. Lecture on Failed States in a Time of Terror, Carleton University, Ottawa, October 7, 2005.

Sloan, Elinor. "Land Threats to North America and the Role of the Army." Paper presented at the conference Canadian Defence and the Canada-U.S. Strategic Partnership, organized by the Centre for Security and Defence Studies (CSDS) at Carleton University, the Calgary-based Canadian Defence \& Foreign Affairs Institute (CDFAI) and the Center for the Study of the Presidency in Washington, DC, Lord Elgin Hotel, Ottawa, September 5-6, 2002.

Wright, James. "The Proliferation Security Initiative." Remarks to the Proliferation Security Initiative Operational Experts Working Group Meeting, Ottawa, April 16, 2004. http://www.dfait-maeci.gc.ca/arms/psi3-en.asp (accessed March 15, 2006).

Wright, Robert. "The New Security Environment in Canada: Are We Getting It Right?" Keynote address delivered to the CASIS 2004 International Conference Peace, Order and Public Safety Post 9/11: Are We Getting It Right?, organized by the Canadian Association for Security and Intelligence Studies, Ottawa, October 14, 2004. 